\author{
Universidade de São Paulo \\ Escola Superior de Agricultura "Luiz de Queiroz" \\ Centro de Energia Nuclear na Agricultura
}

\title{
Diversidade das comunidades bacterianas em solos de terra preta antropogênica da Amazônia Central e Oriental
}

Fabiana de Souza Cannavan

Dissertação apresentada para obtenção do título de Mestre em Ecologia Aplicada

Piracicaba 


\section{Fabiana de Souza Cannavan}

Bióloga

\section{Diversidade das comunidades bacterianas em solos de terra preta antropogênica da Amazônia Central e Oriental}

Orientadora:

Profa. Dra. SIU MUI TSAI

Dissertação apresentada para obtenção do título de Mestre em Ecologia Aplicada

Piracicaba

2007 
Dados Internacionais de Catalogação na Publicação (CIP) DIVISÃO DE BIBLIOTECA E DOCUMENTAÇÃO - ESALQ/USP

Cannavan, Fabiana de Souza

Diversidade das comunidades bacterianas em solos de Terra Preta Antropogênica da Amazônia Central e Oriental / Fabiana de Souza Cannavan. - - Piracicaba, 2007.

115 p. : il.

Dissertação (Mestrado) - - Escola Superior de Agricultura Luiz de Queiroz, 2007.

Bibliografia.

1. Ecologia microbiana 2. Microbiologia do solo 3. RNA 4. Sequenciamento genético Solos I. Título

CDD 631.46

\section{"Permitida a cópia total ou parcial deste documento, desde que citada a fonte - O autor"}




\section{DEDICATÓRIA}

A Deus, pela minha existência, porque nada nos é possível se não for de sua vontade.

Dedico esta minha conquista, aos meus amados pais Luis e Clarice Cannavan por estarem presentes na minha vida, me apoiando em todas as minhas decisões, e acima de tudo, pelo imenso amor... exemplo de simplicidade, humildade, de fé e perseverança.

As minhas irmãs Cristina e Graziela, por serem as melhores irmãs do mundo... e por me concederem as criaturas mais importantes, minhas sobrinhas Leticia e Mariane, alegrias da minha vida. 


\section{AGRADECIMENTOS}

Em primeiro lugar a Deus, por me dar as forças necessárias, a fé e perseverança para a realização deste trabalho. E por me dar uma família maravilhosa.

Aos meus pais, minhas irmãs e sobrinhas, obrigada pelo carinho, conselhos e pela força que tornam meus dias cada vez mais especiais.

À minha orientadora Siu Mui Tsai, pelos importantes ensinamentos tanto científicos quanto pessoais desde minha Iniciação Científica. Agradeço pela amizade, o conforto nas horas difíceis, estímulo constante e fonte de conhecimentos durante todo o trabalho. Obrigada por ser minha "mãe científica"!

Ao Programa BECA - IEB/Fundação Moore (Brasília - DF), pelo suporte financeiro concedido para a realização do curso.

Às Profas. Dra. Dirse Clara Kern e Dra. Aline Aparecida Pizzirani-Kleiner, pelas contribuições indispensáveis.

Às minhas amigas "irmãs" Denise e Lidiane, presentes em minha vida tanto nos momentos de divertimentos inesquecíveis quanto nos mais difíceis, me apoiando, incentivando e que ao meu lado fizeram a diferença. Muito obrigada!!!!

Aos técnicos do Laboratório de Microbiologia e Biologia Molecular, José Elias Gomes, Fábio Rodrigo Sanches Duarte, Wagner Picinini e Francisco Montrazi, pela ajuda prestada, ensinamentos, pela amizade e carinho.

Ao Daniel Saito pela ajuda nas análises computacionais.

Aos amigos e colegas do Laboratório de Microbiologia e Biologia Molecular: Acácio, Daniela, Edi, Estela, Ezio, Lucas, Ludmila, Marina, Mariana, Mateus, Othon pela convivência agradável e amizade.

Ao amigo Raphael Medau, companheiro de coleta, de trabalho e de amizade.

Às "Lulus", Adriane Nunes, Camila Patreze, Caroline Pamplona, Jeanedy Pazinato, Juliana Martinati, Luciana Fedatto, Luciana Ferreira e Karla Nishiyama, que fizeram de nossas reuniões pura diversão e atas memoráveis! Obrigada amigas pelos desabafos.

Às minhas amigas Ana Paula, Camila, Érica, Giana, Graziela, Marcinha, Mariane, Thaís e Sabrina pelos bons momentos de alegria que compartilhamos.

A companheira de laboratório Bianca Furlan. 
Aos meus amigos Gustavo e Paul pelo privilégio de suas amizades e convívio.

Aos meus cunhados Rogério e Fernando.

A secretaria da pós-graduação Regina Celis Telles de Freitas.

A Gilma D`Aquino e José Maxiamiano do Museu Paraense Emilio Goeldi e ao Flavio Vieira Vaz (Pão) e todas as pessoas residentes da Floresta Nacional de Caxiuanã, pela colaboração fundamental nas coleta realizadas em Caxiuanã - PA.

A Jean Peixoto pela colaboração nas coletas realizadas em Presidente Figueiredo - AM

A todos meus tios, tias, primos e primas que me incentivaram.

Enfim, a todos que, mesmo não citados aqui, sabem que de forma direta ou indireta, colaboraram na execução deste trabalho. MUITO OBRIGADA!

“O valor das coisas não está no tempo em que elas duram, mas na intensidade com que acontecem. Por isso existem momentos inesquecíveis, coisas inexplicáveis e pessoas incomparáveis"

Fernando Pessoa 


\section{SUMÁRIO}

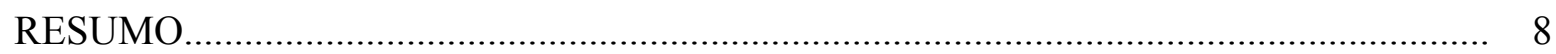

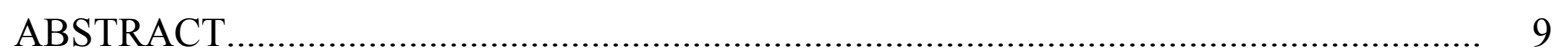

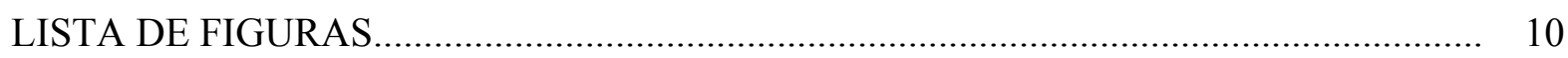

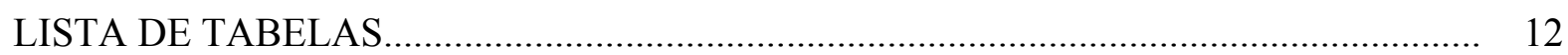

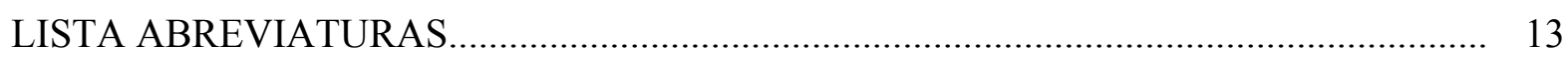

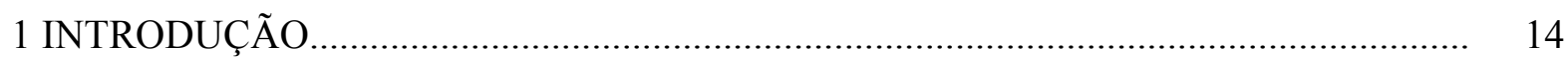

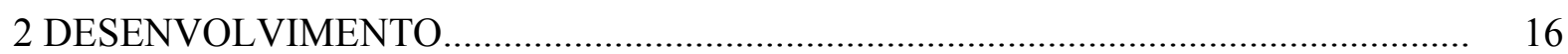

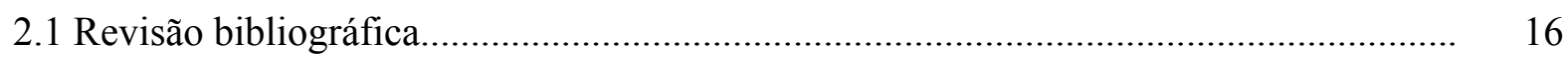

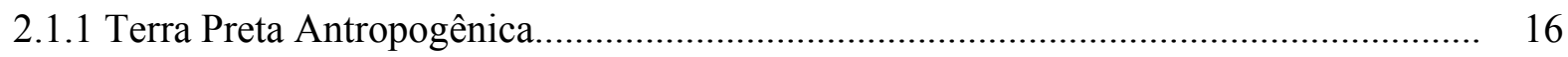

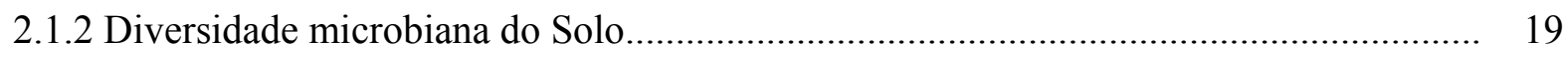

2.1.3 Diversidade bacteriana em solos TPAs da Amazônia.................................................. 22

2.1.4 Importância das técnicas moleculares em estudos de diversidade.................................. 23

2.1.5 Gene 16S rRNA e Análise das seqüências 16S rRNA.................................................. 25

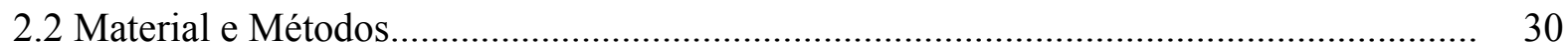

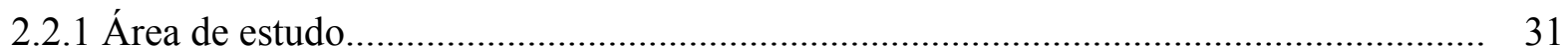

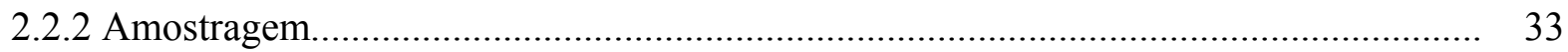

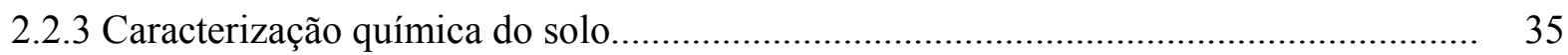

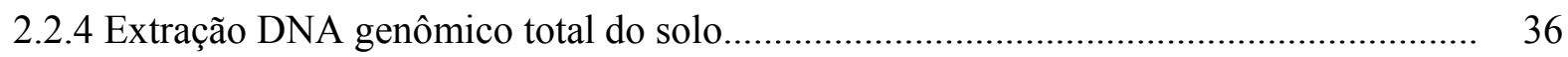

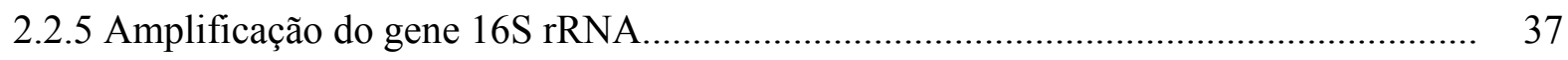

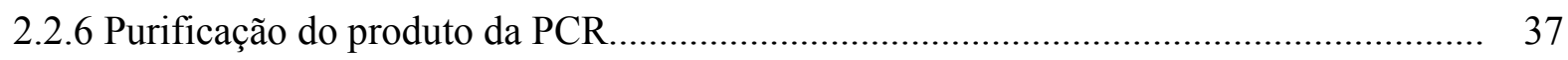

2.2.7 Clonagem do produto da PCR ............................................................................ 38

2.2.8 Preparo de células competentes de E.colli................................................................. 38

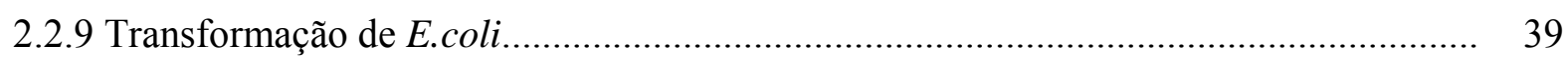

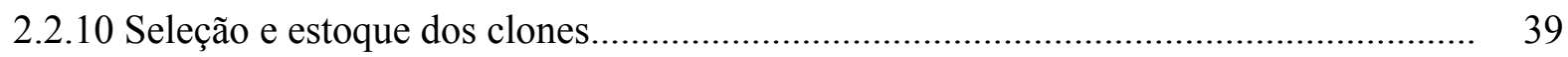

2.2.11 Extração e quantificação do DNA plasmidial............................................................... 40

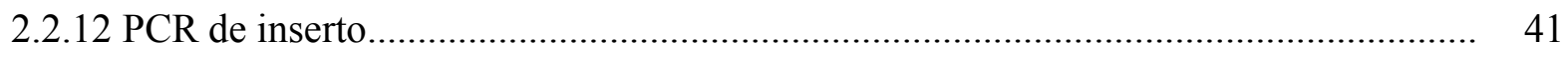

2.2.13 PCR de sequenciamento e precipitação................................................................... 42

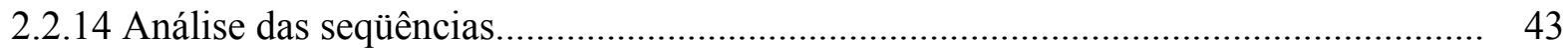

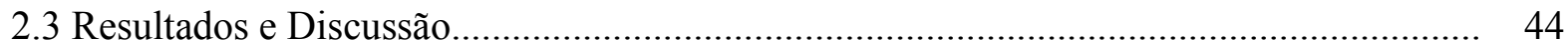


2.3.1 Coleta e caracterização dos solos............................................................................. 44

2.3.2 Extração de DNA genômico total do solo........................................................................... 44

2.3.3 Amplificação e purificação do gene 16S rRNA............................................................ 45

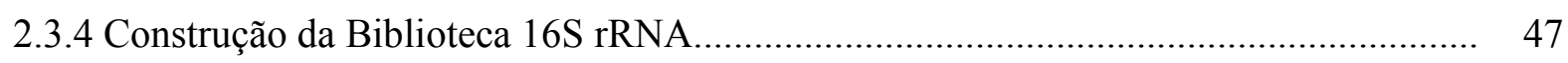

2.3.5 Sequenciamento parcial dos clones e análise das seqüências..................................... 49

2.3.6 Análise de diversidade das comunidades bacteriana................................................. 51

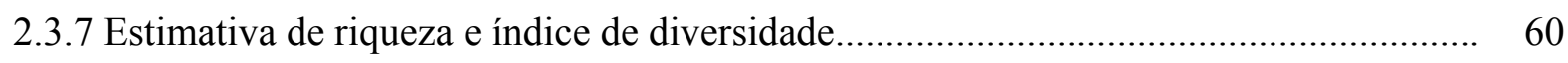

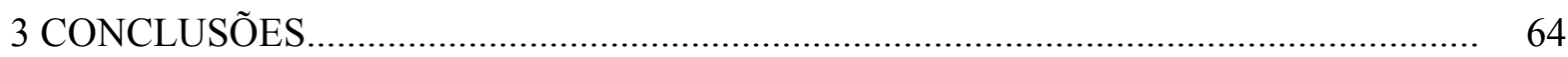

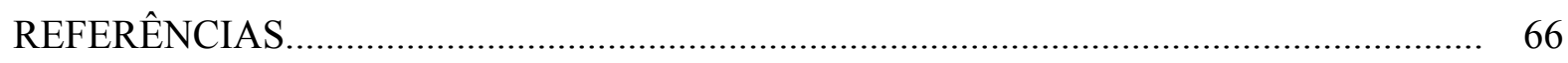

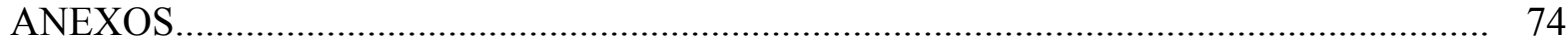




\section{RESUMO}

\section{Diversidade das comunidades bacterianas em solos de Terra Preta Antropogênica da Amazônia Central e Oriental}

Terra Preta Antropogênica (TPA) é um dos tipos de solos mais "férteis" do mundo. A TPA recebe esta denominação por ser encontrada em sítios arqueológicos onde viveram grupos pré-históricos. São pequenas faixas de solos que apresentam altas concentrações de nutrientes, matéria orgânica e encontram-se distribuídas aleatoriamente pela região Amazônica. A verdadeira origem destes solos ainda não está bem esclarecida. Devido à falta de informações sobre sua diversidade bacteriana, este trabalho estudou a diversidade bacteriana em amostras de solos TPA coletadas em duas regiões: Lagoa Balbina - sítio Terra preta (Amazônia CentralAmazonas) e Floresta Nacional de Caxiuanã - sítio arqueológico Mina I (Amazônia Oriental Pará), através de técnicas moleculares independentes de cultivo. O DNA genômico total das amostras de solo foi extraído e usado como molde em uma reação de PCR utilizando oligonucleotídeos específicos do gene 16S rRNA para o Domínio Bactéria. O produto de PCR amplificado foi clonado no vetor pGEM-T e 980 clones foram selecionados e comparados com o banco de dados de 16S rRNA do RDP II e GenBank (NCBI-EUA). Os resultados apresentaram predominância com microrganismos não-conhecidos representando 41,6 \% das seqüências de solo TPA- Balbina, 68,3\% das seqüências de ADJ-Balbina, 84,8\% das seqüências de solo TPAMina e 47,7 \% das seqüências de ADJ-Mina. O filo mais predominante nas amostras TPABalbina foi Firmicutes, representando $37,1 \%$ do total de seqüências analisadas. Os filos em destaque foram Proteobacteria (9,6\%), seguidos de Verrucomicrobia (5,6\%), Acidobacteria (2,5\%), Gemmatimonadetes (2,5\%), Actinobacteria (0,5\%) e Nitrospira (0,5\%). Por outro lado, em ADJ-Balbina destacaram-se os filos Proteobacteria 15,1\%, Acidobacteria (12,5\%), Firmicutes (2,3\%), Nitrospira (1,1\%) e Verrucomicrobia (0,8\%). Em TPA-Mina, os filos apresentados foram Proteobacteria (6,5\%), Acidobacteria (4,7\%), Firmicutes (1,4\%), Nitrospira $(1,1 \%)$, Planctomycetes $(1,1 \%)$ e Verrucomicrobia $(0,4 \%)$. Contudo, na biblioteca ADJ-Mina verificou a presença dos filos Acidobacteria (27,2\%), Proteobacteria (14,2\%), Firmicutes $(3,8 \%)$, Verrucomicrobia (3,8\%), Nitrospira (1,3\%), Planctomycetes $(1,3 \%)$, Actinobacteria $(0,4 \%)$ e Gemmatimonadetes $(0,4 \%)$. O pH do solo pode ser um dos atributos do solo que pode ter influência direta na diversidade bacteriana dos solos estudados, assim como pode ter efeito uma floresta natural sobre as populações microbianas em seu solo, fato observado na adjacência do solo Terra Preta em Caxiuanã - PA. A estimativa da riqueza de UTOs pelo Bootstrap corroborou diretamente os valores de diversidade obtidos pelos índices de Simpson e Shannon. De um modo geral, uma maior probabilidade de ocorrência de UTOs únicas empregadas pelo estimador Jackknife se correlacionou com uma maior percentagem de baixas frequências de filotipos nas quatro bibliotecas. Os métodos não-paramétricos ACE e Chao1 para a estimativa da riqueza de UTOs também corroboraram com os valores obtidos com o estimador Jackknife.

Palavras-chave: Terra Preta; 16S rRNA; Sequenciamento; Diversidade bacteriana; Índices de diversidade 


\begin{abstract}
Diversity of the bacterial communities in Anthropogenic Black Earth from the Central and Oriental Amazon
\end{abstract}

Anthropogenic Dark Earth (ADE) is one of the most fertile soils in the world. ADE soils have received this nomination due to the pre-historical origin of these archaeological sites, established by pre-colombian populations. ADEs are small areas of soil which present high nutrient and organic matter contents and are randomly distributed throughout the Amazonian region. The true origin of these soils is not known yet. Due to the lack of information concerning the bacterial diversity, this work studied the bacterial diversity in ADE soils collected from two regions: Lagoa Balbina - site Terra Preta (Central AmazoniaAmazonas state) and National Forest of Caxiuanã - archaeological site Mina I (Oriental Amazonia - Pará state), using culture-independent molecular techniques. The total genomic DNAs extracted from the soil samples were used as templates in the PCR reactions using the universal primers for the 16S rRNA bacterial gene. The PCR-products were cloned into the pGEM-T vector and 980 clones were selected and searched using the GenBank (NCBI-USA) and the RDP II program. Data analyses indicated predominance of unknown microorganisms, representing $41.6 \%$ among the sequences from ADE-Balbina, $68.3 \%$ from Adjacent-Balbina, 84.8\% from ADE-Mina and $47.7 \%$ from Adjacent-Mina. The predominant phylum in ADEBalbina was Firmicutes, representing 37.1\% of the total sequences from that site, followed by Proteobacteria (9.6\%), Verrucomicrobia (5.6\%) Acidobacteria (2,5\%), Gemmatimonadetes $(2,5 \%)$, Actinobacteria $(0,5 \%)$ and Nitrospira $(0.5 \%)$. On the other hand, in the adjacent soil ADJ-Balbina, the predominant phylla were Proteobacteria (15.1\%), Acidobacteria (12.5\%), Firmicutes (2.3\%), Nitrospira (1.1\%) and Verrucomicrobia (0.8\%). In the Oriental Amazon, the prevalent phylla from the ADE-Mina soil were Proteobacteria (6.5\%), Acidobacteria $(4.7 \%)$, Firmicutes (1.4\%), Nitrospira (1.1\%), Planctomycetes (1.1\%) and Verrucomicrobia (0.4\%). In the ADJ-Mina verificou a presença dos filos Acidobacteria 27.2\%, Proteobacteria 14.2\%, Firmicutes 3.8\%, Verrucomicrobia 3.8\%, Nitrospira 1.3\%, Planctomycetes 1.3\%, Actinobacteria $0.4 \%$ e Gemmatimonadetes $0.4 \%$. The soil $\mathrm{pH}$ may be of the soil attributes which may have directly influenced the bacterial diversity in those soils, as well as the above-ground vegetation from the natural forest in Caxiuanã-Pará. The estimates of the Operational Taxonomic Units (OTUs) richness using Bootstrap directly corroborated the diversity values obtained from the Simpson and Shannon indexes. Unique UTOs using Jackknife estimator were correlated with a higher percentage of the low frequencies of phylla in all the four clone libraries. The nonparametric ACE and Chao1 methods to estimate the OTUs richness also corroborated the Jackknife values.

Key-words: Black Earth; 16S rRNA; Sequencing; Bacterial Diversity; Diversity Index. 


\section{LISTA DE FIGURAS}

Figura 1 - (a) Perfil de solo contendo TPA (coloração escura) sobre camada de latossolo (coloração clara); (b) Fragmentos de cerâmica e artefatos

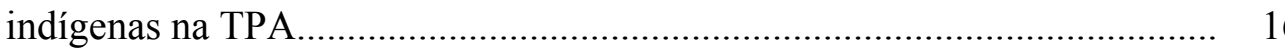

Figura 2 - Localização da área mais elevada onde se encontra a Terra Preta Antropogênica (TPA), localizada na Floresta Nacional de Caxiuanã - sítio Mina I.

Figura 3 - $\quad$ Organização do operon do rRNA ribossômico.

Figura 4 -

Esquema representativo das principais etapas realizadas no trabalho

Figura 5 -

Localização do município de Presidente Figueiredo-AM.

Figura 7 - A vegetação é sempre exuberante onde existe Terra Preta. À direita, Jean Peixoto (UFAM-AM) prepara a trincheira para a coleta de amostras de solo TPA ao longo do perfil, após a limpeza do terreno. Sítio localizado na Lagoa Balbina - Sítio Terra Preta, Hidroelétrica de Balbina, AM

Figura 8 - (a) Coleta realizada no Sítio Mina I - MITPA. (b) Coleta realizada no Sitio Mina I - MIADJ. Este sítio está localizado no Parque Nacional de Caxiuanã - Pará.

Figura 9- (a) - Resultado da amplificação do gene 16S rRNA. Perfil eletroforético em gel de Agarose 1\% contendo Brometo de etídeo. 1 - Padrão de tamanho molecular $1 \mathrm{~kb}$ Plus DNA Ladder (Invitrogen); 2 - Padrão de concentração 200 ng; 3 - BITPA; 4 - BIADJ; 5 - MITPA; 6 - MIADJ e 7 - amostra controle negativo. (b) - Resultado da purificação do gene 16S rRNA. Perfil eletroforético em gel de Agarose 1\% contendo Brometo de etídeo. 1 - Padrão de tamanho molecular $1 \mathrm{~kb}$ Plus DNA Ladder (Invitrogen); 2 - Padrão de concentração 200 ng; 3 - BITPA; 4 - BIADJ; 5 - MITPA; 6 - MIADJ e 7 - amostra controle negativo. 
Figura 10 - Reação de PCR para confirmação da inserção dos fragmentos no vetor de clonagem. 1 - Padrão de tamanho molecular 1 kb Plus DNA Ladder (Invitrogen); 2 a 7 - Clones aleatórios da biblioteca BITPA; 8 a 13 Clones aleatórios da biblioteca BIADJ; 14 - Padrão de tamanho molecular 1 kb Plus DNA Ladder (Invitrogen); 15 - Padrão de tamanho molecular 1 kb Plus DNA Ladder (Invitrogen); 16 a 21 - Clones aleatórios da biblioteca MITPA; 22 a 26 clones aleatórios da biblioteca MIADJ; 27 Amostra controle negativo e 28 - Padrão de tamanho molecular 1 kb Plus DNA Ladder (Invitrogen).

Figura 11 - Diversidade bacteriana encontrada nos solos TPA e adjacentes (Laboa Balbina) nos clones 16S rRNA com base na afiliação filogenética do RDP II pelo programa Library Compare. A - Solo Terra Preta Antropogênica região da Amazônia Central, Lagoa da Balbina;B - Solo adjacente região da Amazônia Central, Lagoa da Balbina.

Figura 12 - Diversidade bacteriana encontrada nos solos TPA e adjacentes (Caxiuana - Mina I) nos clones 16S rRNA com base na afiliação filogenética do RDP II pelo programa Library Compare. A - Solo Terra Preta Antropogênica região da Amazônia Oriental, Floresta Nacional de Caxiuanã, Sítio Mina I; B - Solo adjacente - região da Amazônia Oriental, Floresta Nacional de Caxiuanã, Sítio Mina I.

Figura 13 - Curva de rarefação gerada do gene 16S rRNA das bibliotecas de clones de solo Terra Preta Antropogênica e solo Adjacente da Lagoa Balbina (Amazonas).

Figura 14 - Curva de rarefação gerada do gene 16S rRNA das bibliotecas de clones de solo Terra Preta Antropogênica e solo Adjacente da Floresta Nacional de Caxiuanã (Pará). 


\section{LISTA DE TABELAS}

Tabela 1 - Caracterização química das amostras de solo (Análises realizadas na ESALQ/USP e no Centro de Pesquisa e Desenvolvimento de Solos e Recursos Ambientais do IAC - Campinas, SP)

Tabela 2 - Números totais de clones seqüenciados, válidos e UTOs (Unidades Taxonômicas Operacionais) para análise comparativa com outras seqüências do GeneBank e RDP II.

Tabela 3 - Filos bacterianos encontrados em solos da região Amazônica Central e Oriental comparadas com o bando de dados de seqüências de 16S rRNA do RDP II através do programa Library Compare e números de clones representantes em cada filo encontrados em cada biblioteca Estimativas de riqueza de UTOs (Unidades Taxonômicas Operacionais) e índices de diversidade calculados a partir das bibliotecas de 16S rRNA de bactérias de solo Terra Preta Antropogênica e solo adjacente. 


\section{LISTA ABREVIATURAS}

\begin{tabular}{|c|c|}
\hline$\%$ & Porcentagem \\
\hline${ }^{\circ} \mathrm{C}$ & Grau Celsius \\
\hline$\mu g$ & Micrograma \\
\hline$\mu \mathrm{L}$ & Microlitro \\
\hline $\mathrm{cm}$ & Centímetro \\
\hline DNA & Ácido Desoxirribonucléico \\
\hline dNTPs & Deoxiribonucleosideo Trifosfato \\
\hline EDTA & Ácido Etileno Diamono Tetrecético \\
\hline $\mathrm{g}$ & Grama \\
\hline GET & Glicose, EDTA. Tris-HCL \\
\hline IPTG & Isopropil-beta-D-thiogalactopiranosideo \\
\hline $\mathrm{Kb}$ & Kilobase \\
\hline KOAc & Acetato de Potássio \\
\hline $\mathrm{m}$ & Metro \\
\hline M & Molar \\
\hline $\mathrm{mg}$ & Miligrama \\
\hline $\mathrm{MgCl} 2$ & Cloreto do magnésio \\
\hline $\mathrm{mm}$ & Milímetro \\
\hline $\mathrm{mL}$ & Mililitro \\
\hline $\mathrm{mM}$ & Milimolar \\
\hline $\mathrm{NaOH}$ & Hidróxido de Sódio \\
\hline $\mathrm{nm}$ & Nanômetro \\
\hline ORF & “Operon Reading Frames” (Quadro aberto de leitura) \\
\hline $\mathrm{pb}$ & Pares de Base \\
\hline PCR & "Polymerase Chain Reaction" (Reação de polimerase em cadeia) \\
\hline $\mathrm{pH}$ & Potencial Hidrogeniônico \\
\hline pmol & PicoMoles \\
\hline PVC & Policloreto Cloreto de Vinila \\
\hline RDP & Ribossomal Database Project \\
\hline RNA & Ácido Ribonucléico \\
\hline RNAse & Ribonuclease \\
\hline rRNA & Ácido Ribonucléico Ribossomal \\
\hline rpm & Rotações Por Minuto \\
\hline SDS & Sodium Dodecil Sulfato \\
\hline Taq & Thermus aquaticus \\
\hline TE & Tris-EDTA \\
\hline TPA & Terra Preta Antropogênica \\
\hline Tris & Tris-(hidroximetil)-aminometano \\
\hline $\mathrm{U}$ & Unidade \\
\hline UV & Radiação Ultravioleta \\
\hline $\mathrm{X}-\mathrm{Gal}$ & 5-bromo-4-cloro-3-indolil-beta-D-galactopiranosideo \\
\hline
\end{tabular}




\section{INTRODUÇÃO}

A Terra Preta Antropogênica (TPA) ou Terra Preta de Índio (TPI) é uma unidade de solo de origem antrópica, existente na Amazônia. Provavelmente estes solos foram enriquecidos em nutrientes, pelo manejo de restos orgânicos e do fogo pelas populações pré-colombianas. São solos de coloração escura, altos teores de substâncias húmicas, fragmentos de cerâmica e artefatos indígenas incorporados a matriz dos horizontes superficiais do solo, o que originou a terminologia Terra Preta Antropogênica, utilizada por alguns autores (KERN; COSTA, 1997). Caracterizada por apresentar altos teores de nutrientes como cálcio, magnésio, fósforo e potássio e alguns micronutrientes, como o manganês e o zinco (SOMBROEK, 1966; KERN; KÄMPF, 1989; LEHMANN et al., 2002). As TPAs apresentam pH em torno de 5 a 7, elevados teores de matéria orgânica e intensa atividade biológica quando comparados com solos adjacentes, provenientes, provavelmente, de restos de ossos humanos e de animais (GLASER et al., 2001; LIMA et al., 2002). Outra característica da TPA é a sustentabilidade de sua fertilidade, sendo os microrganismos do solo fundamentais para a persistência da sua fertilidade.

Os microrganismos do solo são componentes essenciais para o funcionamento sustentável dos ecossistemas, sendo fundamentais no processo de fragmentação e decomposição da matéria orgânica e na disponibilização de nutrientes do solo (MOREIRA; SIQUEIRA, 2002).

A falta de conhecimento sobre a diversidade microbiana em amostras ambientais deve-se em grande parte aos métodos tradicionalmente utilizados para o isolamento e cultivo de microrganismos em laboratório (RANJARD et al., 2000). Amann et al. (1995) sugerem que apenas uma pequena fração dos organismos na natureza, ao redor de $0,1 \%$ ou no máximo $10 \%$ do total da população, é cultivável através do uso de técnicas microbiológicas tradicionais, deixando uma vasta porção dessa biota desconhecida e não estudada. A vasta diversidade de microrganismos não-cultiváveis em amostras ambientais estimulou o desenvolvimento de técnicas que permitissem o estudo das comunidades microbianas independentes de cultivo.

Grande avanço recente no campo da biologia molecular (extração de DNA, amplificação por PCR, clonagem de DNA e seqüenciamento de DNA) esta demonstrando a importância dessas 
técnicas em estudos de diversidade microbiana permitindo o desenvolvimento de técnicas que não requerem o isolamento e cultivo de microrganismos, principalmente no estudo das bactérias, tornando possível a identificação dos microrganismos ainda desconhecidos e não identificados.

A maioria dos estudos realizados com TPA está voltada aos aspectos geológicos e antropológicos, sendo que os aspectos biológicos, como a diversidade microbiana do solo ainda são pouco conhecidos. São poucas as informações detalhadas e organizadas sobre esta biodiversidade, assim como estudos sobre o efeito de manejo de TPAs que caracterize a função específica da biodiversidade destes solos no desenvolvimento da sua fertilidade sustentável.

Contudo, este trabalho teve como objetivo estudar a diversidade bacteriana em solos TPA e respectivos solos adjacentes, na região Amazônica Central e Oriental, através de métodos moleculares. A diversidade das comunidades bacterianas foi avaliada através da extração do DNA genômico total do solo seguido de amplificação, clonagem e sequenciamento parcial do gene $16 \mathrm{~S}$ rRNA. Por tanto esse estudo se torna importante para ilustrar o impacto das comunidades bacterianas presentes na TPA. 


\section{DESENVOLVIMENTO}

\subsection{Revisão Bibliográfica}

\subsubsection{Terra Preta Antropogênica}

Na Amazônia os principais solos agricultáveis encontrados são os Latossolos Amarelos e os Argissolos, representando $74,7 \%$ da região, considerados solos pobres em nutrientes, com alto teor de acidez e com baixa capacidade de troca de cátions (VIEIRA; SANTOS, 1987), tornandose um fator limitante para a produtividade e sustentabilidade dos sistemas de produção agrícola desta região. Porém, na mesma região é encontrado um dos solos mais férteis do mundo identificado como Terra Preta Antropogênica (TPA) ou Terra Preta de Índio, representando uma pequena parcela dos solos Amazônicos, provavelmente cobrindo pelo menos entre 0,1 a $0,3 \%$ (15.500-20.700 km²) da área florestada da Amazônia (SOMBROEK et al., 2003).

A TPA recebe esta denominação por ser encontrada em sítios arqueológicos onde viveram grupos pré-históricos (KERN; COSTA, 1997). Caracterizada por apresentar altos teores de nutrientes como cálcio, magnésio, fósforo e potássio e alguns micronutrientes, como o manganês e o zinco (SOMBROEK, 1966; KERN; KÄMPF, 1989; LEHMANN et al., 2002). Esses solos apresentam $\mathrm{pH}$ em torno de 5 a 7 , elevados teores de matéria orgânica e intensa atividade biológica quando comparados com solos adjacentes, provenientes, provavelmente, de restos de ossos humanos e de animais (GLASER et al., 2001; LIMA et al., 2002). Também, a saturação por alumínio e ferro é baixa (KERN; KÄMPF, 1989). Os solos TPAs são de coloração escura, altos teores de substâncias húmicas e visível distribuição de fragmentos de cerâmica e artefatos indígenas incorporados a matriz dos horizontes superficiais do solo (Figura 1), por vezes fragmentos ou acúmulos de conchas e carvão (BAENA; FALESI, 2001). As áreas com TPA são encontradas sobre os mais diversos tipos de solos, como latossolos, podizóis, podizólicos e terra roxa estruturada (SMITH, 1980; KERN, 1988; KERN; KAMPF, 1989), e normalmente se localizam em terra firme próxima às margens de baía, rios e igarapés, ocupando posições em áreas mais elevadas (Figura 2). 

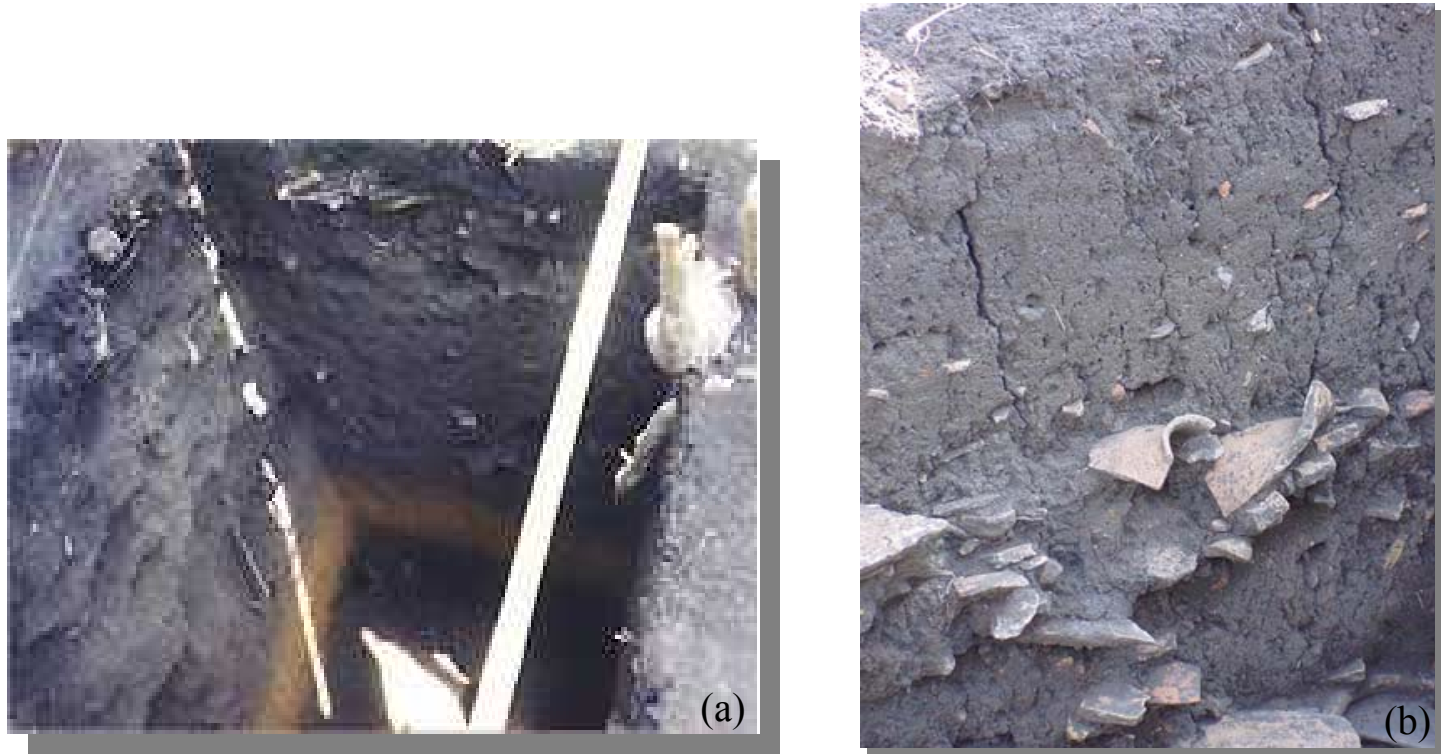

Figura 1 - (a) Perfil de solo contendo TPA (coloração escura) sobre camada de latossolo (coloração clara);

(b) Fragmentos de cerâmica e artefatos indígenas na TPA

Estes solos ocorrem em manchas redondas isoladas (FALESI et al., 1972) de diferentes dimensões. Ocupam normalmente pequenas áreas, em torno de 0,5 a 3 hectares (SMITH, 1980), havendo, porém, indicações de sítios, na Estação Científica Ferreira Penna - Floresta Nacional de Caxiuanã (PA), que se estendem por mais de 100 ha. Apesar da grande quantidade de sítios arqueológicos já conhecidos, não se tem um mapeamento de todas as ocorrências de TPA na Amazônia. Quanto à espessura, está geralmente em torno de $30 \mathrm{a} 60 \mathrm{~cm}$, podendo em alguns sítios atingir até $2 \mathrm{~m}$ de profundidade (SMITH, 1980). Apresenta a seguinte seqüência de horizontes: A1, A2, AB, BA e B, onde a camada antrópica é mais expressiva nos horizontes A e AB.

A TPA foi descrita pela primeira vez por Hartt (1885) quando este pesquisava os arredores de Taperinha - Pará, o qual se referiu as terras pretas da seguinte maneira: “(...) os solos consistem em uma rica e fofa terra vegetal de cor preta, conhecida pelo nome de terra preta". Este solo é extremamente fértil, ficando úmido durante toda a estação de seca e especialmente apropriado para a cultura de cana. Desde 1960 os estudos realizados com Terra Preta eram tradicionalmente do domínio de arqueólogos, etnobotânicos, geógrafos e cientistas do solo trabalhando individualmente. A partir de 1980 a pesquisa com Terra Preta tornou-se 
interdisciplinar e multidisciplinar (ERICKSON, 2003). Wim Sombroek incluiu os solos chamados Terra Preta de Índio em sua dissertação sobre solos Amazônicos publicada em 1966, disponibilizando os primeiros estudos químicos observando seu potencial para o aumento da fertilidade do solo (LEHMANN et al., 2002).

A grande dúvida e as maiores divergências sobre a terra preta é a sua formação. Uma das hipóteses seria de que a TPA é originada de eventos geológicos, cinzas vulcânicas, decomposição de rochas vulcânicas ou a partir de sedimentos depositados nos fundos de lagos extintos (FALESI, 1972). Contudo, dados mais recentes apontam que a TPA teria origem antrópica, ou seja, seria resultado de antigos assentamentos indígenas, particularmente ao longo dos rios.

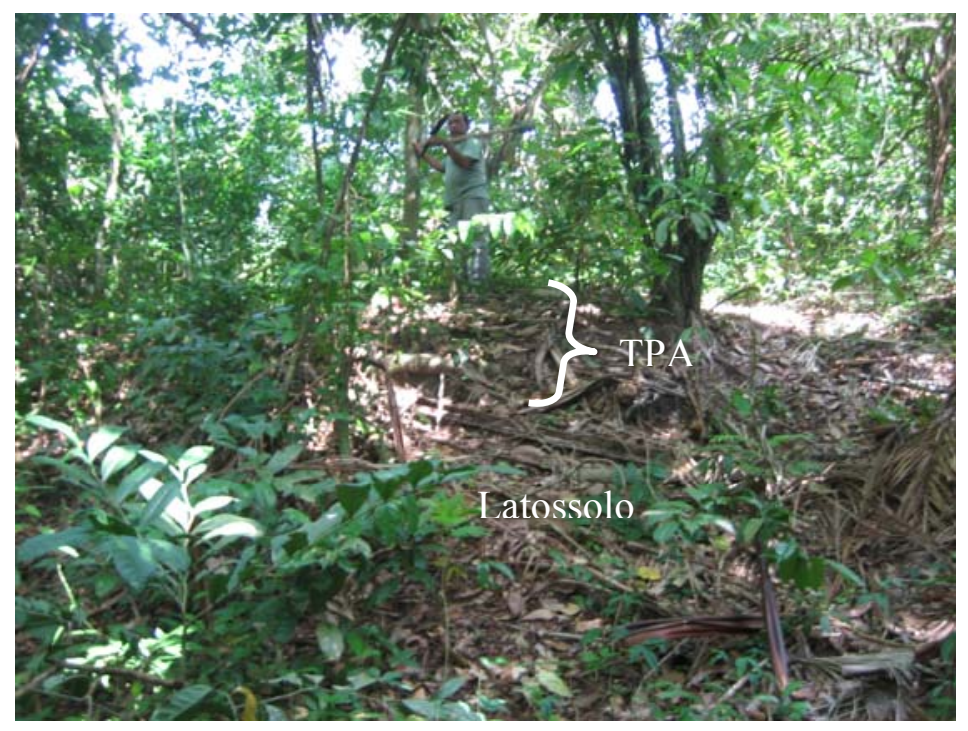

Figura 2 - Localização da área mais elevada onde se encontra a Terra Preta Antropogênica (TPA), localizada na Floresta Nacional de Caxiuanã - sítio Mina I

Provavelmente estes solos de origem antrópica foram enriquecidos em nutrientes pelo manejo de restos orgânicos e do fogo pelas populações pré-colombianas, ao longo de centenas de anos. Como resultado dos resíduos orgânicos, vegetal e animal, acumulados nesses assentamentos como folhas, sementes, cascas de mandioca, ossos, sangue, fezes, conchas, formouse um material orgânico estável com microecossistemas próprios que não se esgotam rapidamente, sendo que o efeito do uso agrícola na fertilidade de TPA, comparado com outros 
solos da região é menos danoso por causa do efeito tampão que nas TPAs podem existir, ou seja, o uso agrícola pouco altera sua ótima fertilidade (MADARI et al., 2002).

Os microrganismos do solo são fundamentais para a persistência da fertilidade conforme demonstrado recentemente em levantamento sobre as comunidades bacterianas em quatro solos TPAs e adjacências (O’NEILL et al., 2006).

A presença de material orgânico estável e a grande atividade biológica indicam que a TPA pode ser um sítio de alta diversidade microbiana, constituindo numa fonte de germoplasma microbiano (TSAI et al., 2003). Atualmente são poucas as informações detalhadas e organizadas sobre esta biodiversidade, assim como estudos sobre o efeito de manejo de TPAs que caracterize a função específica da biodiversidade destes solos no desenvolvimento da sua fertilidade sustentável. A maioria dos estudos realizados com TPA está voltada aos aspectos geológicos e antropológicos, sendo que os aspectos biológicos, como por exemplo, a diversidade microbiana do solo ainda são pouco conhecidos.

\subsubsection{Diversidade Microbiana do Solo}

Os microrganismos procarióticos dividem-se, taxonomicamente, em dois domínios: Bacteria e Archaea, representando a maior parte da biota da Terra (LAMBAIS et al., 2005). Segundo estimativas de Whitman et al. (1998), entre 2-3\% dos procariotos ocorrem nas águas dos oceanos, 4,5-6,5\% ocorrem no solo e a vasta maioria em subsuperfície (LAMBAIS et al., 2005).

Os microrganismos do solo são componentes essenciais para o funcionamento sustentável dos ecossistemas, sendo fundamentais no processo de fragmentação e decomposição da matéria orgânica e na disponibilização de nutrientes do solo, entre outras (MOREIRA; SIQUEIRA, 2002). As atividades dos microrganismos estão baseadas em sua notável diversidade metabólica e adaptabilidade genética (KURTBOKE et al., 2004), o que os torna uma importante fonte de recursos genéticos para o avanço biotecnológico e para o desenvolvimento sustentável. Entretanto, para uma qualidade do solo é importante manter a diversidade microbiana, pois os 
microrganismos desempenham funções importantes como a remoção de toxinas, participação no ciclo de carbono, nitrogênio, fósforo, e outros (BORNEMAN et al., 1996).

Tradicionalmente, os microrganismos são estudados individualmente e caracterizados, através do desenvolvimento de técnicas de cultivo puro, por critérios nutricionais e bioquímicos. Contudo, a abordagem de cultivo puro limita a avaliação taxonômica e filogenética da diversidade microbiana devido à impossibilidade de cultivo da grande parte dos microrganismos através de métodos convencionais (PACE, 1997), os chamados microrganismos não cultiváveis. Esses métodos clássicos de cultivo microbiano limitam o conhecimento sobre as interações ecológicas entre os microrganismos, o que dificulta e impede a compreensão de processos dinâmicos que ocorrem no meio ambiente (ATLAS; BARTHA, 1997). No entanto, tem sido demonstrado que os microrganismos cultivados representam apenas uma pequena fração da diversidade de espécies em comunidade microbiana. Um grama de solo pode conter 10 bilhões de microrganismos, representando milhares de espécies (ROSSELÓ-MORA; AMANN, 2001). Porém, a diversidade é tão vasta quanto desconhecida.

Entretanto, na última década, estudos com diversidade microbiana do solo têm sido bastante discutidos devido ao grande avanço dos estudos moleculares que têm favorecido a avaliação dos microrganismos em amostras ambientais (TIEDJE et al., 2001). O principal argumento a favor das técnicas moleculares em estudos envolvendo amostras ambientais se dá ao fato de a diversidade microbiana permanecer-se naturalmente inalterada ao longo do ano (JOHNSON et al., 2003). Desta maneira, as ferramentas moleculares e tecnologias baseadas em seqüências gênicas vêm reduzindo as limitações existentes com métodos de cultivo e revelando novas perspectivas sobre a diversidade dos microrganismos.

A caracterização dos microrganismos não-cultiváveis, utilizando métodos moleculares é uma maneira de identificar e conhecer suas distribuições e funções no meio ambiente. Microrganismos não-cultiváveis presentes no solo são filogeneticamente distintos dos cultiváveis e seus requerimentos para cultura em laboratório ainda não foram determinados. Com isso, essa hipótese tem sido apoiada por trabalhos indicando que a diversidade microbiana presentes em 
diversos ambientes é maior que aquela obtida pela análise de seqüência de microrganismos cultiváveis (RONDON et al., 1999).

Os estudos de diversidade microbiana através de técnicas moleculares geralmente envolvem o sequenciamento de um trecho do DNA que seja informativo, como genes contendo seqüências conservadas para o desenho de oligos iniciadores e ao mesmo tempo contendo seqüências variáveis do ponto de vista filogenético. Um gene bastante utilizado neste tipo de análise é o gene 16S rRNA (ácido ribonucléico ribossomal).

Com o desenvolvimento das técnicas de classificação de microrganismos com base nas seqüências de nucleotídeos do rRNA, o número de espécies microbianas descritas tem aumentado significantemente (LAMBAIS et al., 2005). O domínio Bactéria compreende 25 filos enquanto que o domínio Archaea compreende 23 filos (GARRITY et al., 2004). Segundo Lewinsohn e Prado (2002) estimava-se que no Brasil existia um número entre 300 a 450 espécies de bactérias descritas e conhecidas. Mundialmente o número de bactérias descritas, segundo os mesmos autores, era em torno de 4200 espécies, isso demonstra a necessidade de conhecer e estudar a diversidade bacteriana, tornando-se necessários métodos rápidos de análises para a diversidade microbiana.

Recentemente, Lambais et al. (2006), estudaram a biodiversidade microbiana em filosfera de três espécies de árvores da Floresta Amazônica e indicaram um diversidade de 95 a 671 espécies por amostra.

Estudos de diversidade bacteriana em solos de florestas subtropical e tropical do sudeste da China, foram realizados através de análises de seqüências e Terminal Restriction Fragment Length Polymorphism (T-RFLP) do gene 16S rRNA. A predominância de Acidobateria foi verificada em ambos os solos estudados, seguidos por Proteobacteria, Planctomycete e Verrucomicrobia (CHAN et al., 2006).

Gomez-Alvarez et al. (2007) caracterizaram a diversidade bacteriana do solo de quatro áreas de depósitos vulcânicos no Hawaii, ocorridos em 1959, 1921, 1790 e 1700. Através da 
caracterização molecular utilizando o gene 16S rRNA para construção de bibliotecas, observouse que, por influência de alguns parâmetros ambientais, o maior índice de diversidade foi encontrado no deposito de 1790, o menor em 1921 e valores intermediários nos depósitos de 1959 e 1700. Nas áreas de 1959 e 1790 houve predominância das comunidades Acidobacteria, Alpha e Gammaproteobacteria, Actinobacteria, Cyanobacteria e muitos organismos não classificados.

\subsubsection{Diversidade bacteriana em solos TPAs da Amazônia}

Estudos realizados com amostras de solo de floresta e pastagem na região da Amazônia oriental (próximo ao município de Paragominas-PA), utilizando técnicas moleculares como: amplificação, clonagem e sequenciamento do gene 16S rRNA, revelaram a ocorrência de microrganismos pouco comuns em amostras ambientais e demonstram também o impacto do desmatamento sobre a diversidade microbiana. Os resultados demonstraram em 98\% o predomínio do Domínio Bactéria em relação a 2\% a Archaea, sendo que algumas seqüências sugerem a existência de uma nova subdivisão do grupo Proteobacteria (BORNEMAN; TRIPLETT, 1997).

Recentemente Kim et al. (2007) realizaram estudos de diversidade bacteriana com amostras de solos de floresta e solo TPA, na região da Amazônia Ocidental, utilizando técnicas moleculares a partir de seqüências do gene 16S rRNA de 1500 clones. Observou-se a predominância de Acidobateria em ambos os solos, porém, solos de TPA apresentaram 25\% a mais de diversidade bacteriana.

Nos ecossistemas amazônicos, durante a época seca, os microrganismos (principalmente fungos e bactérias) atuam em grande número na liteira em decomposição sobre o solo a fim de garantir a incorporação dos elementos minerais no perfil do solo. Rizóbio, fungos micorrízicos e solubilizadores de fosfato são microrganismos do solo que têm indicado suas importâncias nos ecossistemas de terra firme, inclusive com aumentos significativos no desenvolvimento das plantas (FARIAS; OLIVEIRA, 1994). Alguns microrganismos encontrados em TPA são capazes de sintetizar as substâncias húmicas de forma diferente dos demais microrganismos, encontrados 
em solos adjacentes. Desta forma, os microrganismos de TPA podem ter contribuído para a formação e sustentabilidade destes solos.

Solos TPAs podem exibir considerável heterogeneidade espacial e temporal na distribuição de populações microbianas (THIES; SUZUKI, 2003). Tsai et al. (2003) avaliaram a diversidade bacteriana em solos TPAs, coletados na região da Estação Experimental de Iranduba, pertencente a Embrapa Amazônia Ocidental. A área coletada possui um histórico de uso agrícola, contudo esta abandonada por volta de 20 anos, tendo assim estabelecida uma vegetação secundária. Esse trabalho utilizou técnicas moleculares com base no seqüenciamento do gene $16 \mathrm{~S}$ rRNA. Os autores encontraram além de uma alta diversidade bacteriana, alta ocorrência de clones homólogos a bactérias não cultivadas. Isto demonstra a necessidade de maior intensidade de estudos nesses ambientes, que podem ser "hot spot" de diversidade bacteriana pouco conhecida.

Atualmente, há um grande interesse científico na elucidação da gênese de TPA, principalmente pela possibilidade de replicação destas áreas.

\subsubsection{Importância das técnicas moleculares em estudos de diversidade}

A falta de conhecimento sobre a diversidade microbiana em amostras ambientais deve-se em grande parte aos métodos tradicionalmente utilizados para o isolamento e cultivo de microrganismos em laboratório (RANJARD et al., 2000). Amann et al. (1995) sugerem que apenas uma pequena fração dos organismos na natureza, ao redor de $0,1 \%$ ou no máximo $10 \%$ do total da população, é cultivável através do uso de técnicas microbiológicas tradicionais, deixando uma vasta porção dessa biota desconhecida e não estudada.

O conhecimento da biodiversidade e bioprospecção de novos microrganismos tornam-se uns dos focos principais da era biotecnológica, visto que a utilização destes organismos na busca de soluções nas áreas de alimento, saúde, meio ambiente e indústria vêm crescendo de forma acelerada no atual cenário mundial. Métodos tradicionalmente utilizados para a detecção e identificação das bactérias eram realizados de acordo com os principais meios de obtenção de carbono e energia, exigências nutricionais e meio de cultivo para seu crescimento, além da 
observação via microscópio (KENNEDY, 1999; HERBERT, 1990), os quais forneciam informações limitadas com necessidade de maior refinamento. Torsvik et al. (1990) estudaram populações bacterianas de solo através de técnicas moleculares, os quais encontraram 4000 diferentes genomas, sendo uma estimativa 200 vezes maior do que a obtida através das técnicas tradicionais.

Os avanços recentes no campo da biologia molecular (extração de DNA, amplificação por PCR, clonagem de DNA e seqüenciamento de DNA) estão demonstrando a importância dessas técnicas em estudos de diversidade microbiana permitindo o desenvolvimento de técnicas que não requerem o isolamento e cultivo de microrganismos, principalmente no estudo das bactérias, tornando possível a identificação dos microrganismos ainda desconhecidos e não identificados.

Com o desenvolvimento da técnica conhecida como PCR (Polymerase Chain Reaction) os métodos moleculares receberam um grande impulso. Descrita por Saiki et al. (1985), essa técnica permite amplificar pequenos e específicos fragmentos do genoma, permitindo a obtenção de várias cópias de determinada região do DNA. Devido à reação ser específica pode-se obter a amplificação de seqüências de nucleotídeos-alvo mesmo em uma amostra que tem grande diversidade de seqüências, permitindo a detecção de organismos específicos em misturas heterogêneas. Seqüências do DNA de determinados microrganismos podem ser amplificadas, utilizando-se primers (seqüências iniciadoras) complementares àquelas localizadas em locais específicos do genoma. O que ocorre é a extensão do fragmento de DNA a partir dos primers, pela ação de uma DNA polimerase termoestável, a Taq DNA polimerase (isolada originalmente do microrganismo Thermus aquaticus). Antes da extensão o DNA é desnaturado e o primer anelado sendo o ciclo repetido várias vezes, permitindo a amplificação exponencial daquela seqüência específica (SAIKI et al., 1985).

Grande parte das técnicas moleculares utilizadas atualmente apropria-se da PCR ou de suas variações para o estudo da diversidade microbiana nos mais diferentes ambientes (REIS JR et al., 2002). Outras técnicas moleculares, têm sido amplamente empregadas na caracterização de comunidades de microrganismos em amostras ambientais, como de DGGE (Denaturing Gradient Gel Electrophoresis), de RFLP (Restriction Fragment Length Polymorphism), ARDRA 
(Amplified Ribosomal DNA Restriction Analysis), T-RFLP (Terminal Restriction Fragment Length Polymorphism), rRNA (ácido ribonucléico ribossomal) como marcador filogenético e PCR-clonagem-sequenciamento - metagenômica. Essas técnicas moleculares vêm sendo muito utilizadas para aprimorar os estudos da diversidade bacteriana nos mais diferentes ambientes.

\subsubsection{Gene 16S rRNA e análise das sequiências 16S rRNA}

O ribossomo bacteriano é composto do RNA ribossomal e várias proteínas. Ele é constituído de duas subunidades principais, a $40 \mathrm{~S}$ (denominada subunidade maior) e a $30 \mathrm{~S}$ (subunidade menor). Na subunidade maior estão as moléculas de 23S, 5S rRNA e mais 31 proteínas (Figura 3). Na subunidade menor estão o 16S rRNA e mais 21 proteínas (WOODSON; LEONTIS, 1998). Os genes rRNAs, são universalmente distribuídos nos diferentes grupos de seres vivos, sendo a molécula que apresenta o maior grau de conservação existente. Sua variabilidade pode apresentar-se em maior ou menor extensão em diferentes regiões da molécula (LANE et al., 1985). O 16S rRNA, é um fragmento de aproximadamente 1500 nucleotídeos, são presentes em todos os seres vivos e gera grande quantidade de informações úteis para inferências filogenéticas (AMANN; LUDWING, 2000). A vantagem de utilizar essa técnica é a disponibilidade de um grande número de seqüências da 16S rRNA depositadas em bancos de dados como Gen-Bank, RDP, EMBL acessíveis gratuitamente, permitindo a comparação de novas seqüências obtidas com as seqüências presentes nessas bases (COUTINHO et al., 1999). Seu papel funcional no sistema de processamento de informações deve ter sido bem estabelecido nos primeiros ancestrais comuns de Bactérias - Archaea e Eucarya.

O marco principal do uso de marcadores moleculares foi quando Woese em 1987 descreveu o uso do gene 16S rRNA (RNA ribossômico) na filogenia de bactérias (WOESE, 1987). As seqüências de rRNA contendo domínios altamente conservados, intercalados com regiões variáveis (HEAD et al., 1998). A comparação de seqüências de rRNA é uma ferramenta importante para determinação de relações filogenéticas e evolutivas entre os organismos (WEISBURG et al., 1991), na avaliação da diversidade em amostras ambientais e na detecção e quantificação de populações especificas (HEAD et al., 1998). 


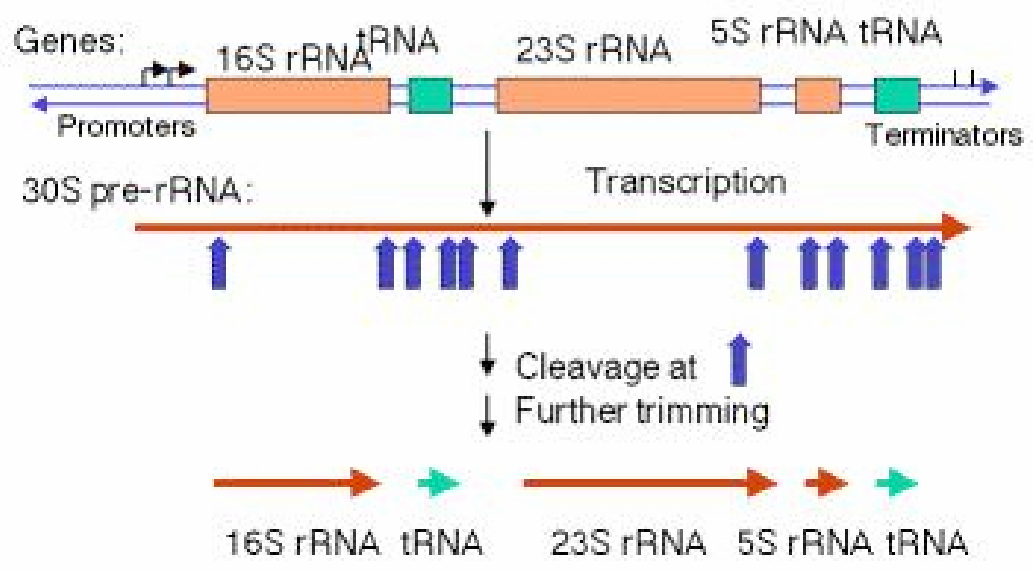

Figura 3 - Organização do operon do RNA ribossômico

(Fonte: http://www.personal.psu.edu/.../image002.png)

Metagenoma é a análise genômica de microrganismos de uma amostra ambiental que na sua maioria não pode ser isolada e crescida em laboratório. Uma biblioteca genômica derivada da amplificação dessas amostras é produzida pelo método de clonagem. Os DNAs metagenômicos amplificados a partir de primers específicos são ligados em vetores apropriados pela ação da DNA ligase e, em seguida, é caracterizada uma parcela dos clones via sequenciamento ou análise de restrição (ARMANN; LUDWING, 2000; MCCAIG et al., 1999). Após o sequenciamento dos clones de amostras ambientais é gerada uma grande quantidade de seqüências de nucleotídeos. Essas seqüências são editadas para remoção de bases de baixa qualidade, por meio dos programas PHRED/PHRAP (BRENT; PHILL, 1998), para posteriormente serem utilizadas em estudos de filogenia. O tratamento de grandes quantidades de dados exige uma abordagem sistemática e automatizada, havendo necessidade de algoritmos específicos (LAMBAIS et al., 2005).

Normalmente as análises da diversidade e a comparação da de comunidades de procariotos são baseadas no grau de similaridade entre seqüências de $16 \mathrm{~S}$ rRNA, as quais são agrupadas em unidades taxonômicas operacionais (UTOs) ou filotipos (NUBEL et al., 1999; STACH et al., 2003). As seqüências de 16S rRNA com similaridade maiores que 97\% são consideradas da mesma espécie, maiores que $95 \%$ do mesmo gênero e maiores que $80 \%$ do mesmo filo (BORNEMAM; TRIPLETT, 1997; NUBEL et al., 1999; SCHLOSS; 
HANDELSMAN, 2005). O uso de UTOs é apropriado para comparar riqueza relativa quando se avalia seqüências de 16S rRNA de uma mesma região ou de mesmo tamanho (STACH et al., 2003). No entanto, a estimativa da diversidade baseada em UTOs deve ser cuidadosamente interpretada, já que os níveis de similaridade entre as seqüências de 16S rRNA para definição de UTOs não são consensuais (NUNES, 2006).

As seqüências de 16S rRNA geradas a partir do sequenciamento podem ser comparadas com seqüências depositadas em bancos de dados públicos (GenBank do NCBI e Ribosomal Database Project II). O banco de dados do GenBank permite a determinação do organismo com seqüência mais similar e suas possíveis funções no solo (CURY, 2006). O banco de dados do Ribosomal Database Project II (RDP II) permite a determinação das relações filogenéticas das seqüências de 16S rRNA obtidas com seqüências depositadas. O RDP II obtém as seqüências de rRNA mensalmente a partir do Banco de Dados de Seqüência Internacional (International Nucleotide Sequence Database: GenBank/EMBL/DDBJ). Essas seqüências são alinhadas com seqüências gerais de rRNA bacteriano através de um modelo que incorpora informações sobre a estrutura secundária da molécula aumentando a confiabilidade. O RDP possui também um sistema de classificação taxonômica (RDP Hierarchy) que segue a proposta do Manual Bergeys (GARRITY et al., 2004) no qual os principais níveis taxonômicos, em ordem decrescente são: Domínio, Filo, Classe, Ordem, Família, Gênero e Espécie.

A comparação do banco de dados do RDP II feita através do programa Classifier utiliza um sistema de pareamento de palavras combinado com uma estatística de Baesyana (COLE et al., 2005). O programa Classifier tem como objetivo fornecer uma classificação taxonômica inicial para a seqüência submetida e requer um alinhamento prévio dessa seqüência com as seqüências disponíveis no RDP Hierarchy.

Métodos paramétricos e não-paramétricos são utilizados para estimar a riqueza de filotipos em comunidades microbianas de amostras ambientais (BOHANNAN; HUGHES, 2003; GASTON, 1996; CHAO et al., 2006; SHEN et al., 2003). Estimativas do aumento de UTOs em função do número de seqüências de um nível filogenético são feitas pelo método da rarefação. Outros métodos são utilizados para estimar a riqueza de UTOs na comunidade, tais como o 
estimador Jackknife baseado na freqüência observada de UTOs raras e o estimador Bootstrap definido por sub amostragens aleatórias do conjunto de filotipos. São empregados ainda os métodos não-paramétricos ACE (Abundance based Coverage Estimator) e Chao1 (CHAO et al., 2006) capazes de promover estimativas que também variam com o número de seqüências.

Devido à complexidade da série logarítmica e da distribuição Lognormal e a baixa justificativa teórica para estas técnicas estatísticas têm-se retomado uma variedade de medidas não-paramétricas de diversidade que não fazem suposição sobre a forma da curva espécieabundância. A primeira medida não-paramétrica de diversidade foi proposta por Simpson (1949). Simpson sugeriu que a diversidade era inversamente relatada pela probabilidade de que dois indivíduos escolhidos ao acaso pertencessem à mesma espécie (KREBS, 1998). A medida mais popular de diversidade de espécies é o índice de Shannon (H') (SHANNON; WEANER, 1949). Esta medida é baseada na teoria da informação, sendo considerada uma medida da incerteza de que duas seqüências pertençam à mesma UTOs. Quanto maior o valor de H', maior a incerteza (KREBS, 1998).

Os dados gerados a partir da clonagem do $16 \mathrm{~S}$ rRNA tem possibilitado a característica da estrutura da comunidade microbiana presente em uma determinada amostra e a identificação de espécies predominantes, que podem ser utilizadas como indicadoras de qualidade do solo. Por exemplo, baseado nestas técnicas, foi identificada uma bactéria não cultivável em meio de cultura tradicional capaz de oxidar amônia e (LIESACK; STACKEBRANDT, 1992; FELSKE et al., 1997), mostrando que o gênero Nitrosomonas, ao contrário que se pensava, não é o grupo funcional mais importante desse processo dentre as bactérias do solo.

Em estudos recentes tem confirmado que esta forma de análise é uma fonte vasta de recursos para a prospecção de novos produtos biotecnológicos (COURTOIS et al., 2003; MACNEIL et al., 2001; RONDON et al., 1999). Novos genes e novos produtos gênicos têm sido descobertos através dessa técnica, incluindo novas moléculas com atividade antimicrobiana e novos membros de famílias de proteínas conhecidas (HANDELSMAN, 2004). 


\section{Objetivos}

\section{Objetivo geral}

Determinar a diversidade microbiana, através de métodos moleculares independentes de cultivo, em solos TPA (Terra Preta Antropogênica) e respectivos solos adjacentes, em dois sítios localizados:

a) Amazônia Central (Lagoa Balbina - AM);

b) Amazônia Oriental (Floresta Nacional de Caxiuanã - PA).

\section{Objetivos específicos}

- Isolar DNA genômico total dos solos Terra Preta Antropogênica e os respectivos solos adjacentes coletados em duas regiões: Lagoa Balbina (Amazônia Central- Amazonas) e Floresta Nacional de Caxiuanã - sítio arqueológico Mina I (Amazônia Oriental - Pará);

- Amplificação, clonagem do gene 16S rRNA de Bactéria, e sequenciamento da região inicial 5'do gene que codifica para o $16 \mathrm{~S}$ rRNA dos clones obtidos;

- Análise comparativa da diversidade bacteriana presente no solo TPA e respectivo solo adjacente, através do banco de dados de seqüências de 16S rRNA do RDP II pelo programa Library Compare e programa Classifier;

- Determinação da diversidade bacteriana através de índices de diversidade Simpson Shannon e estimadores de riqueza ACE, Chao1, Jackknife e Bootstrap. 


\subsection{Material e Métodos}

O presente trabalho foi desenvolvido no Laboratório de Microbiologia e Biologia Molecular do Centro de Energia Nuclear na Agricultura da Universidade de São Paulo, CENA/USP, Piracicaba-SP. Uma representação explicativa das etapas realizadas neste trabalho pode ser visualizada na Figura 4.

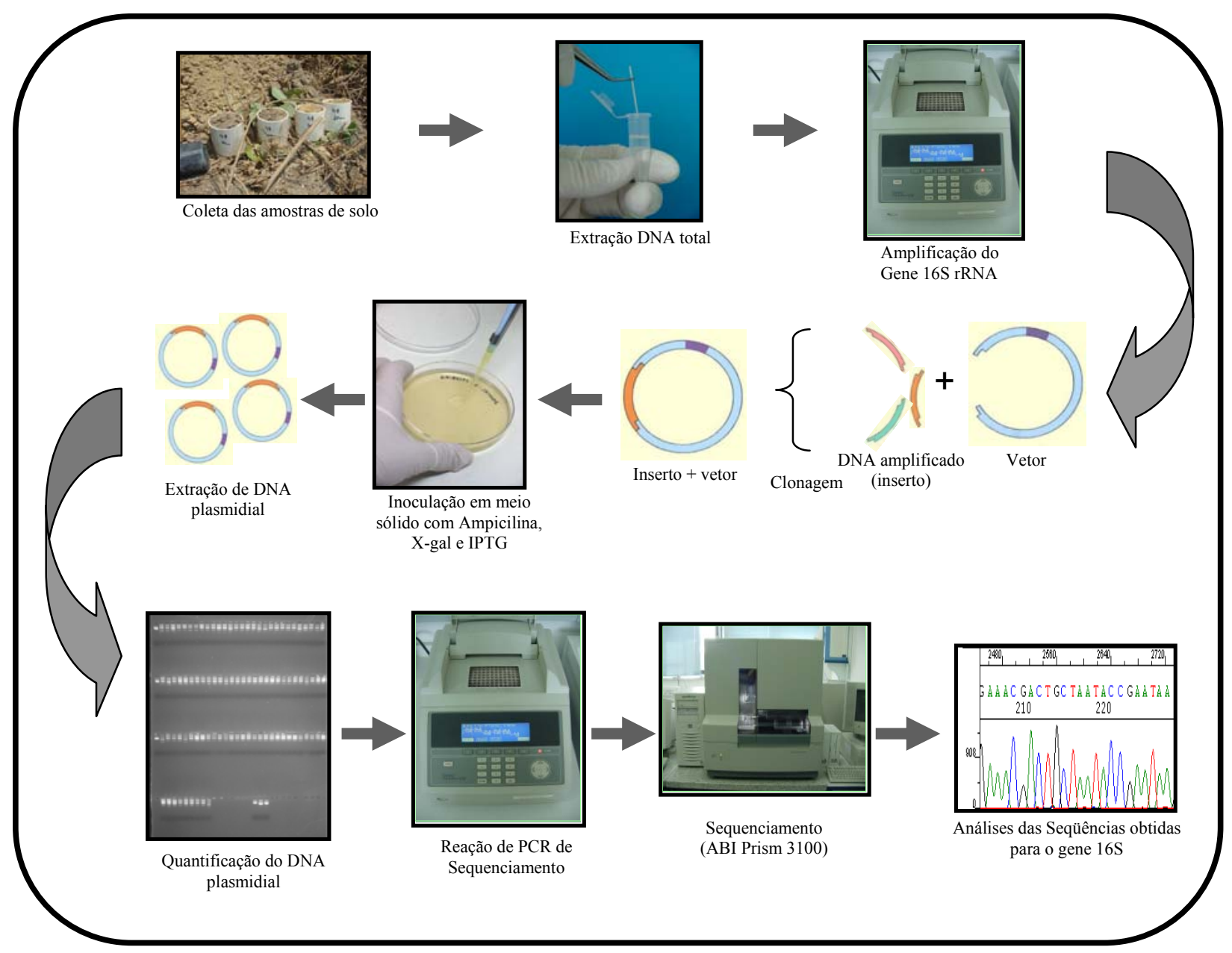

Figura 4 - Esquema representativo das principais etapas realizadas no trabalho 


\subsection{1 Área de estudo}

Foram coletados solos TPAs não perturbados e adjacências em duas regiões: Lagoa Balbina (Amazônia Central- Amazonas) e Floresta Nacional de Caxiuanã (Amazônia Oriental Pará). A primeira área de estudo está localizada próxima à Comunidade Rumo Certo no município de Presidente Figueiredo (AM), às margens da lagoa da Hidroelétrica Balbina, na Amazônia Central, a $187 \mathrm{~km}$ de Manaus (Figura 5). As coordenadas geográficas da área de TPA são $1^{\circ} 30^{\prime} 26,4$ ”S e $60^{\circ} 05^{\prime} 34^{\prime \prime} \mathrm{W}$, e da área de solo adjacente são $1^{\circ} 30^{\prime} 27^{\prime}$ 'S e $60^{\circ} 05^{\prime} 33^{\prime \prime} \mathrm{W}$. O clima é quente e úmido com temperatura média entre $25^{\circ} \mathrm{C}$ e $35^{\circ} \mathrm{C}$. A vegetação é formada pela Floresta Tropical, com grande predominância de terras acidentadas e o solo apresenta características arenosas nas áreas mais altas e argilosas nas áreas mais baixas. A área de TPA é classificada como Latossolo Amarelo Antrópico e o solo adjacente, caracterizado como solo de agricultura de subsistência, localizado entre as áreas de TPA e várzea. O solo adjacente é classificado como Latossolo Amarelo, não tendo sido cultivado ou perturbado por mais de 20 anos.

A segunda área de estudo está localizada na Floresta Nacional de Caxiuanã, a $400 \mathrm{~km}$ de Belém (PA), a qual se encontra no município de Melgaço/PA, na Amazônia Oriental, entre a ilha de Marajó e o rio Xingu (Figura 6). As coordenadas geográficas da área de TPA são 140’45,5”S e $51^{\circ} 20^{\prime} 71^{\prime \prime} \mathrm{W}$. O clima é quente e úmido com temperatura média entre $25^{\circ} \mathrm{C}$ e $35^{\circ} \mathrm{C}$. Nesta área foram catalogados mais de 27 sítios TPAs que atestam a ocupação humana da região por povos pré-colombianos (SILVEIRA et al., 2002; KERN; COSTA 1997). O sítio TPA conhecido como Sítio Mina I (sítio sambaqui - acúmulo de conchas, antes denominada Mina de Sarnambi, devido às conchas serem retiradas para a fabricação de cal), está incluído dentre os sítios catalogados na Floresta Nacional de Caxiuanã. Essa área, apesar de não haver moradia atualmente, possui plantações de seringueiras, laranja, açaí, buriti, etc. O solo adjacente possui coloração marrom, classificado como floresta nativa natural e se encontra a aproximadamente 100 metros da trincheira do solo TPA. 

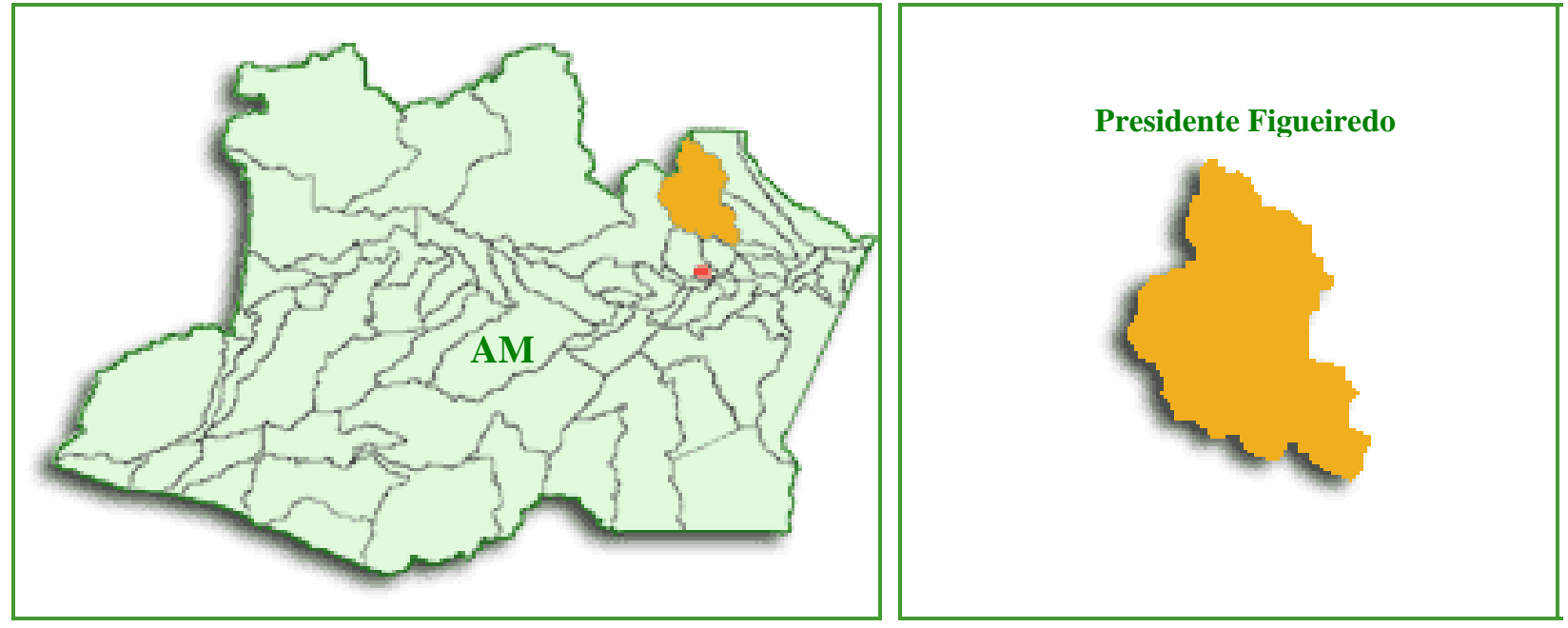

Figura 5 - Localização do município de Presidente Figueiredo-AM

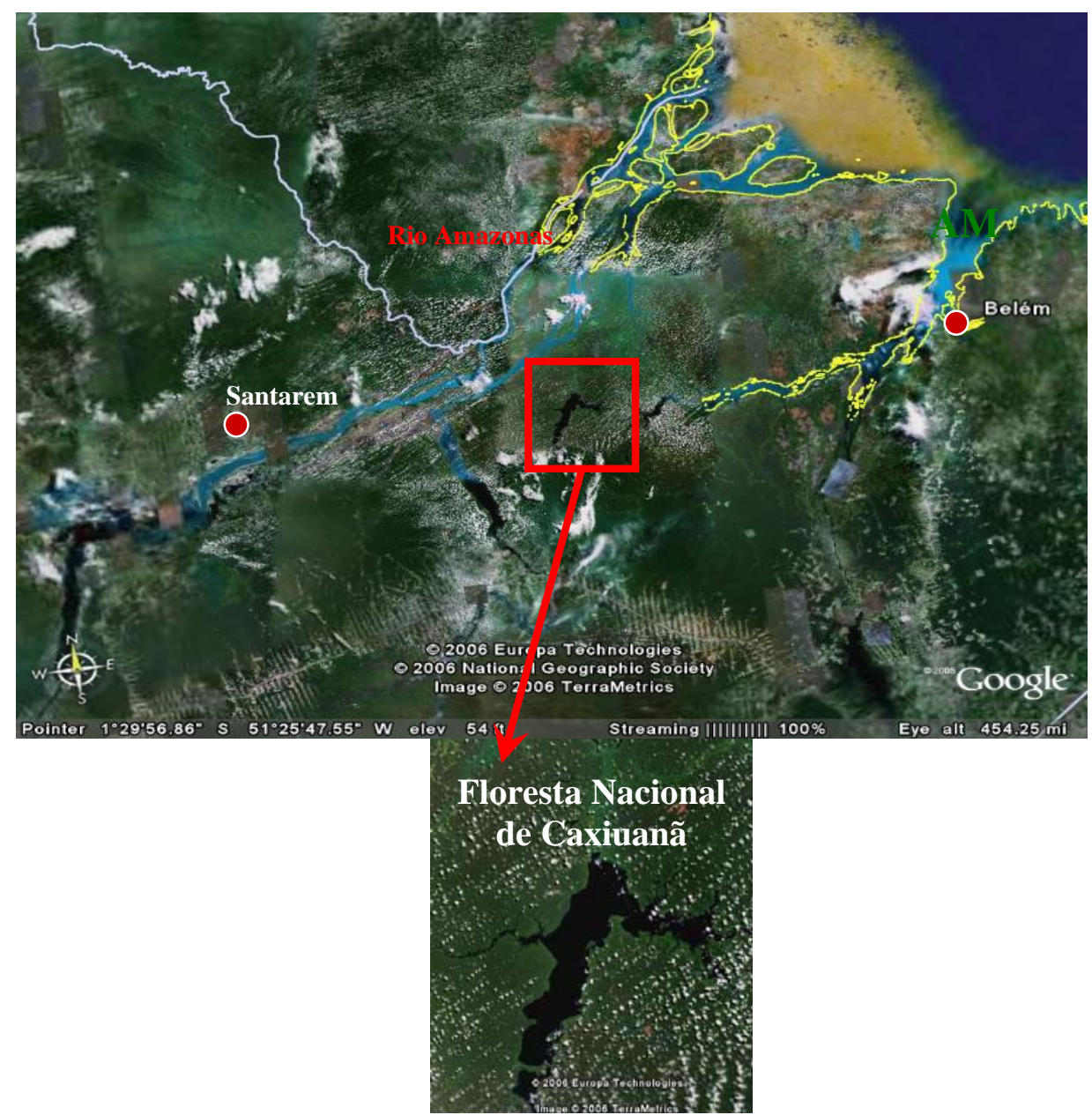

Figura 6 - Localização da Floresta Nacional de Caxiuanã. Fonte: Google 


\subsubsection{Amostragem}

Foram feitas quatro coletas de solos na área de Presidente Figueiredo (Figura 7): duas em solo TPA, amostras de 10 e $20 \mathrm{~cm}$ de profundidade (BITPA), e duas em solo adjacente à TPA, amostras de 10 e 20 cm (BIADJ). Na área de Floresta Nacional de Caxiuanã - Sítio Arqueológico Mina I também foram realizadas quatro coletas de solos: duas em solo TPA, amostras de 10 e 20 cm (MITPA), e duas em solo adjacente à TPA, amostras de 10 e $20 \mathrm{~cm}$ (MIADJ).

As coletas foram realizadas com tubos de PVC $(5 \mathrm{~cm}$ de comprimento por $50 \mathrm{~mm}$ de diâmetro) previamente esterilizados, a uma trincheira de $1 \mathrm{x} 1 \mathrm{~m}$ e de, aproximadamente, $60 \mathrm{~cm}$ de profundidade (Figura $8 \mathrm{a}$; b), com cinco repetições em cada profundidade, totalizando 40 amostras. Após a coleta as amostras foram acondicionadas, armazenadas sob baixa temperatura $\left(4^{\circ} \mathrm{C}\right)$ e enviadas imediatamente para o Laboratório de Biologia Celular e Molecular CENA/USP.

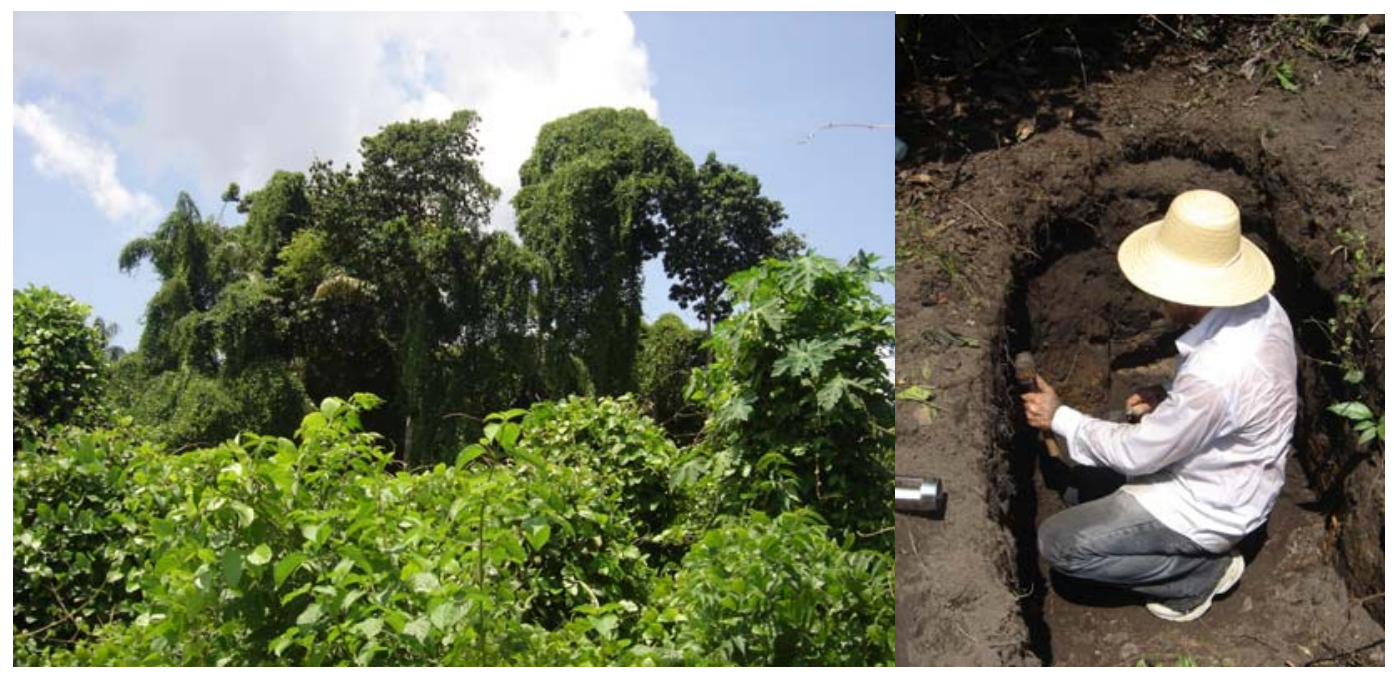

Figura 7 - A vegetação é sempre exuberante onde existe Terra Preta. À direita, Jean Peixoto (UFAMAM) prepara a trincheira para a coleta de amostras de solo TPA ao longo do perfil, após a limpeza do terreno. Sítio localizado na Lagoa Balbina - Sítio Terra Preta, Hidroelétrica de Balbina, AM 

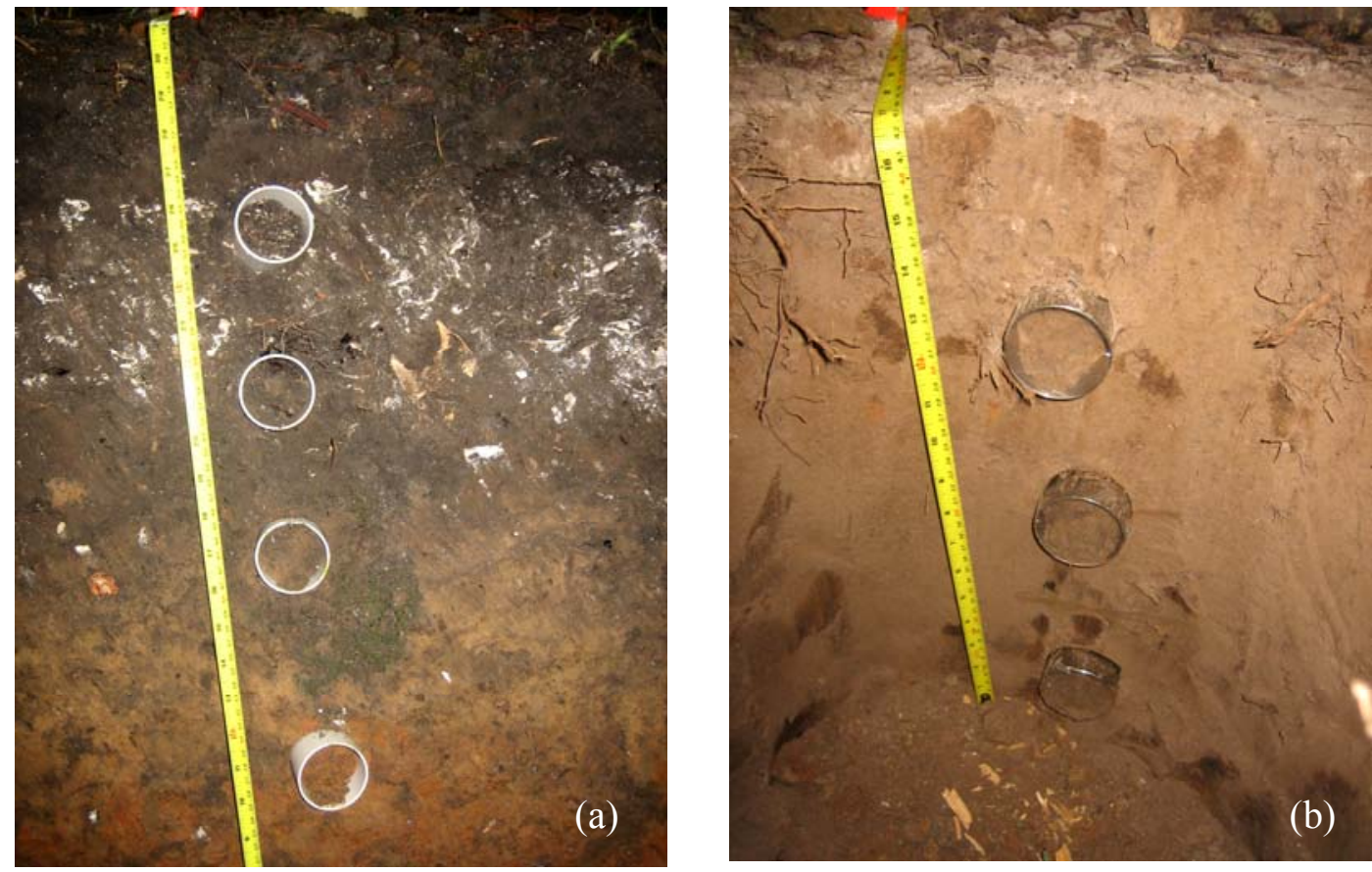

Figura 8 - (a) Coleta realizada no Sítio Mina I - MITPA. (b) Coleta realizada no Sitio Mina I - MIADJ. Este sítio está localizado no Parque Nacional de Caxiuanã - Pará 


\subsubsection{Caracterização química do solo}

Foram realizadas análises químicas dos solos das 4 amostras avaliadas neste estudo (Tabela 1), sendo elas: Balbina Terra Preta (BITPA) e Adjacente (BIADJ) e Mina I Terra Preta (MITPA) e Adjacente (MIADJ). As amostras analisadas foram compostas de 5 repetições para cada profundidade.

Tabela 1 - Caracterização química das amostras de solo (Análises realizadas na ESALQ/USP e no Centro de Pesquisa e Desenvolvimento de Solos e Recursos Ambientais do IAC - Campinas, SP)

\begin{tabular}{|c|c|c|c|c|c|c|c|c|c|c|c|c|c|c|c|c|c|}
\hline Amostra & $\begin{array}{c}\text { Profundidade } \\
\text { cm }\end{array}$ & $\begin{array}{c}\mathrm{pH} \\
\mathrm{CaCl}_{2}\end{array}$ & $\begin{array}{l}\text { M.O } \\
\text { g/dm }\end{array}$ & $\begin{array}{c}P \\
g / \mathrm{dm}^{3}\end{array}$ & $\begin{array}{c}\mathrm{K} \\
\mathrm{g} / \mathrm{dm}^{3}\end{array}$ & $\begin{array}{c}\mathrm{Ca} \\
\mathrm{g} / \mathrm{dm}^{3}\end{array}$ & $\begin{array}{c}\mathrm{Mg} \\
\mathrm{g} / \mathrm{dm}^{3}\end{array}$ & $\begin{array}{c}\mathrm{Al} \\
\mathrm{g} / \mathrm{dm}^{3}\end{array}$ & $\begin{array}{l}\mathrm{H}+\mathrm{Al} \\
\mathrm{g} / \mathrm{dm}^{3}\end{array}$ & $\begin{array}{c}\text { S.B } \\
\text { g/dm }\end{array}$ & $\begin{array}{l}\text { CTC } \\
\text { g/dm }\end{array}$ & $\begin{array}{l}\mathrm{V} \\
\%\end{array}$ & $\begin{array}{c}\text { B } \\
\mathrm{mg} / \mathrm{dm}^{3}\end{array}$ & $\begin{array}{c}\mathrm{Cu} \\
\mathrm{mg} / \mathrm{dm}^{3}\end{array}$ & $\begin{array}{c}\text { Fé } \\
\mathrm{mg} / \mathrm{dm}^{3}\end{array}$ & $\begin{array}{c}\text { Mn } \\
\mathrm{mg} / \mathrm{dm}^{3}\end{array}$ & $\begin{array}{c}\mathrm{Zn} \\
\mathrm{mg} / \mathrm{dm}^{3}\end{array}$ \\
\hline BITPA & $00-10$ & 4,7 & 55 & 17 & 0,6 & 54 & 8 & 2 & 98 & 62,6 & 160,6 & - & - & - & - & - & - \\
\hline BITPA & $10-20$ & 4,6 & 50 & 15 & 0,6 & 38 & 5 & 4 & 88 & 43,6 & 131,6 & - & - & - & - & - & - \\
\hline BIADJ & $00-10$ & 4,4 & 54 & 11 & 1,1 & 35 & 9 & 5 & 80 & 45,1 & 125,1 & - & - & - & - & - & - \\
\hline BIADJ & $10-20$ & 3,7 & 23 & 4 & 0,3 & 6 & 1 & 16 & 121 & 7,3 & 128,3 & - & - & - & - & - & - \\
\hline MITPA & $00-10$ & 7,2 & 59 & 195 & 0,3 & 426 & 1 & $<1$ & 9 & 427,3 & 436 & 98 & 0,1 & 1,2 & 16 & 13,5 & 2,6 \\
\hline MITPA & $10-20$ & 7,3 & 30 & 135 & 0,2 & 264 & 1 & $<1$ & 8 & 265,2 & 273 & 97 & 0,08 & 0,7 & 11 & 9,5 & 1 \\
\hline MIADJ & $00-10$ & 4,0 & 27 & 21 & 0,6 & 17 & 1 & 15 & 80 & 18,6 & 98,1 & 19 & 0,2 & 0,2 & 214 & 3,4 & 0,5 \\
\hline MIADJ & $10-20$ & 4,0 & 20 & 19 & 0,3 & 8 & $<1$ & 22 & 88 & 8,3 & 96,7 & 9 & 0,16 & 0,2 & 204 & $<0,1$ & 0,3 \\
\hline
\end{tabular}

S.B: Soma de Bases; CTC: Capacidade de Troca Catiônica; V: Saturação por Bases; BITPA: Balbina TPA; BIADJ: Balbina adjacente; MITPA: Mina TPA; MIADJ: Mina Adjacente; (-) não determinada 


\subsubsection{Extração DNA genômico total do solo}

O DNA total do solo de cada uma das quatro áreas de coleta (BITPA, BIADJ, MITPA e MIADJ) foi extraído com 3 repetições para cada profundidade $(10$ e $20 \mathrm{~cm})$, totalizando 24 amostras, usando-se o Power Soil DNA Isolation Kit (MOBio) de acordo com as instruções do fabricante, brevemente descrito abaixo. Em microtubo de $2 \mathrm{~mL}$ contendo micro esferas de vidro foram adicionados $0,25 \mathrm{~g}$ de amostras de solo e agitado gentilmente para homogeneizar. Foram adicionados $60 \mu \mathrm{L}$ de solução $\mathrm{C} 1$ e o tubo foi agitado por 10 minutos. Após, as amostras foram centrifugadas a $14.000 \mathrm{rpm}$ por 30 segundos e o sobrenadante foi transferido para um novo tubo. Adicionou-se $250 \mu \mathrm{L}$ de solução $\mathrm{C} 2$, o tubo foi agitado por 5 segundos e incubado a $4^{\circ} \mathrm{C}$ por 5 minutos. As amostras foram centrifugadas a $14.000 \mathrm{rpm}$ por 1 minuto e o sobrenadante transferido para tubo novo. Foi adicionado $200 \mu \mathrm{L}$ de solução C3, o tubo foi agitado e incubado a $4^{\circ} \mathrm{C}$ por 5 minutos. Novamente as amostras foram centrifugadas a $14.000 \mathrm{rpm}$ por 1 minuto e o sobrenadante transferido para tubo novo. Adicionou-se $1200 \mu \mathrm{L}$ de solução $\mathrm{C} 4$ e o tubo foi agitado por 5 segundos. Todo o material foi transferido para uma coluna (com filtro) contendo um tubo coletor e centrifugado a $14.000 \mathrm{rpm}$ por 1 minuto. Essa etapa foi repetida por três vezes. Adicionou-se $500 \mu \mathrm{L}$ de solução C5 e o tubo foi centrifugado a $14.000 \mathrm{rpm}$ por 30 segundos, descartou-se o sobrenadante e centrifugou-se novamente a $14.000 \mathrm{rpm}$ por 1 minuto. O tubo coletor foi descartado e a coluna transferida para novo tubo. Para eluição do DNA foi adicionado $100 \mu \mathrm{L}$ de solução C6, centrifugado a $14.000 \mathrm{rpm}$ por 30 segundos e a coluna foi descartada.

Para a quantificação do DNA extraído, uma alíquota de $5 \mu \mathrm{L}$ de DNA adicionada de $3 \mu \mathrm{L}$ de tampão de carregamento $(0,025 \%$ de azul de bromofenol e $50 \%$ de glicose) foi analisada através de eletroforese em gel de agarose $1 \%$, contendo brometo de etídio $(0,5 \mu \mathrm{g} / \mathrm{mL}$ de gel $)$. Como padrão de tamanho de DNA foi utilizado o marcador molecular $1 \mathrm{~kb}$ Plus DNA Ladder ${ }^{\mathrm{TM}}$ (Invitrogen Life Technologies, São Paulo, Brasil). O gel foi documentado através do programa "Multi Analyst" do Flúor-S ${ }^{\mathrm{TM}}$ Multimager (BioRad, Hercules, California, E.U.A.). 


\subsubsection{Amplificação do gene 16S rRNA}

A reação de amplificação do gene $16 \mathrm{~S}$ rRNA de Bactéria das amostras de solo foi realizada em solução contendo $2,5 \mu \mathrm{L}$ de tampão para PCR 10X; 0,2 mM de cada dNTP; $3 \mathrm{mM}$ de $\mathrm{MgCl}_{2} ; 1,5 \mathrm{U}$ de Platinum Taq DNA Polimerase (Invitrogem); 10 ng de DNA; 5 pmol de primer fD1 (5'-AGAGTTTGATCCTGGCTCAG-3') e rD1 (5'-AAGGAGGTGATCCAGCC-3') (WEISBURG et al., 1991); água Milli-Q esterilizada para um volume final de $25 \mu \mathrm{L}$. O DNA de cada área utilizado na reação constitui-se de uma mistura das três repetições, nas duas profundidades. A reação foi feita em termociclador (GeneAMP PCR System 9700 - Applied Biosystems) nas seguintes condições: $94^{\circ} \mathrm{C}$ por 4 minutos, 25 ciclos com desnaturação a $94^{\circ} \mathrm{C}$ por 1 minuto, anelamento a $55^{\circ} \mathrm{C}$ por 30 segundos, extensão a $72^{\circ} \mathrm{C}$ por 2 minutos e extensão final a $72^{\circ} \mathrm{C}$ por 10 minutos. Ao final do programa a amostra permaneceu no termociclador a $4^{\circ} \mathrm{C}$. O produto amplificado foi verificado em gel de agarose $1 \%$, utilizando como padrão de tamanho de DNA o marcador molecular 1 kb Plus DNA Ladder ${ }^{\mathrm{TM}}$ (Invitrogen Life Technologies, São Paulo, Brasil). O gel foi documentado através do programa "Multi Analyst" do Flúor-S $\mathrm{S}^{\mathrm{TM}}$ Multimager (BioRad, Hercules, California, E.U.A.).

\subsubsection{Purificação do produto da PCR}

Após a obtenção do produto da PCR foi feita a purificação utilizando Kit GFX PCR DNA and Gel Band Purification (Amersham Biosciences), conforme as instruções do fabricante. Esta purificação foi feita cortando-se as bandas contendo o produto da PCR, com auxilio de bisturi. Em seguida, o cubo de gel contendo a banda foi transferido para microtubo previamente pesado. Para cada $1 \mathrm{mg}$ de cubo de gel foi adicionado $1 \mu \mathrm{L}$ de tampão captura e incubado a $60^{\circ} \mathrm{C}$ por 15 minutos. A mistura foi transferida para uma coluna GFX (com filtro) contendo um tubo coletor e centrifugada por 30 segundos a $14.000 \mathrm{rpm}$. O material que passou pela coluna foi descartado. $\mathrm{Na}$ coluna foi adicionado $500 \mu \mathrm{L}$ de tampão de lavagem e centrifugada por 30 segundos a 14.000 rpm por duas vezes. A coluna foi transferida para um novo microtubo e para eluição do DNA foi adicionado $50 \mu \mathrm{L}$ de TE (Tris-HCL 1M, EDTA 0,5 M), incubado por 1 minuto a temperatura ambiente e centrifugado por 1 minuto a $14.000 \mathrm{rpm}$. Cinco microlitros $(5 \mu \mathrm{L})$ do material purificado foram quantificados em gel de agarose $1 \%$, contendo marcador de peso molecular 
pGEM (Applied Bioystems). O gel foi documentado através do programa "Multi Analyst" do Flúor-S $\mathrm{S}^{\mathrm{TM}}$ Multimager (BioRad, Hercules, California, E.U.A.). O produto purificado foi armazenado a $-20^{\circ} \mathrm{C}$ até posterior utilização.

\subsubsection{Clonagem do produto da PCR}

O produto amplificado e purificado da PCR do gene 16S rRNA, dos solos Balbina TPA e adjacente e Mina TPA e adjacentes, foi clonado em vetor pGEM-T Easy, de acordo com as instruções do Kit pGEM-T Easy Vector (Promega). A reação de ligação do produto de PCR purificado ao vetor pGEM - T consistiu-se de: $1 \mu \mathrm{L}$ de T4 DNA ligase $(3 \mathrm{U} / \mu \mathrm{L}) ; 5 \mu \mathrm{L}$ de tampão T4 ligase 1X, aproximadamente $100 \mathrm{ng}$ de produto de PCR purificado e $54 \mathrm{ng}$ de vetor pGEM-T.

Para saber a quantidade necessária em ng do produto de PCR a ser utilizado na clonagem foi realizada a seguinte equação:

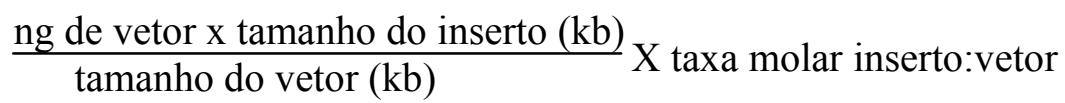

A taxa molar inserto:vetor utilizada foi de 3:1.

A reação foi incubada a $4^{\circ} \mathrm{C}$ overnight para obter-se uma maior eficiência de ligação.

\subsubsection{Preparo de células competentes de E.colli}

Células competentes de E.coli DH5 $\alpha$ foram preparadas quimicamente utilizando o método de cloreto de cálcio (SAMBROOK et al., 1989). Células de uma colônia isolada de E.coli, crescidas anteriormente em placa de Petri contendo meio Luria Broth - LB ( $1 \%$ de triptona; 0,5\% de extrato de levedura; $0,25 \%$ de $\mathrm{NaCl} ; 4 \%$ de agar), foram inoculadas em $10 \mathrm{~mL}$ de meio $\mathrm{LB}$ líquido, o qual foi incubado a $37^{\circ} \mathrm{C}$ por 16 horas, sob agitação constante de $200 \mathrm{rpm}$ (New Brunswick Scientific - C24 Incubator Shaker, Edison NJ, USA). Cem microlitros da cultura crescida foi adicionado a $25 \mathrm{~mL}$ de meio LB líquido para reinoculação, mantendo-se o frasco incubado a $37^{\circ} \mathrm{C}$ por aproximadamente 4 horas, sob agitação constante de $200 \mathrm{rpm}$, até atingir 
uma absorbância de 0,5 a $600 \mathrm{~nm}$. As células foram transferidas para tubo de $50 \mathrm{~mL}$ e incubadas no gelo por 10 minutos. $\mathrm{O}$ tubo foi centrifugado a $3.500 \mathrm{rpm}$, por 15 minutos a $15^{\circ} \mathrm{C}$. $\mathrm{O}$ sobrenadante foi descartado e foi adicionado $1 / 2$ volume de uma solução gelada e esterilizada de $\mathrm{CaCl}_{2} /$ glicerol (50 mM de $\mathrm{CaCl}_{2}$ e $10 \%$ de glicerol). As células foram incubadas no gelo por 15 minutos e centrifugadas a $3.500 \mathrm{rpm}$, por 15 minutos a $15^{\circ} \mathrm{C}$. As células foram gentilmente ressuspendidas em $1 / 5$ do volume da solução gelada de $\mathrm{CaCl}_{2} /$ glicerol. Alíquotas de $100 \mu \mathrm{L}$ foram transferidas para microtubos e armazenadas a $-80^{\circ} \mathrm{C}$.

\subsubsection{Transformação de E.coli}

A eficiência de transformação das células foi medida usando protocolo de transformação através de choque térmico (SAMBROOK et al., 1989) com plasmídeo comercial de concentração conhecida. A eficiência foi estimada em $10^{8}$ transformantes por $\mu \mathrm{g}$ de DNA.

O vetor contendo o inserto foi inserido em células competentes de E.coli DH5 $\alpha$ através de choque térmico (SAMBROOK et al., 1989). O processo de transformação foi feito da seguinte forma: $2 \mu \mathrm{L}$ do produto de ligação e $50 \mu \mathrm{L}$ de células competentes foi adicionado em microtubo, misturado gentilmente e incubado no gelo por 30 minutos. Em seguida o microtubo foi incubado a $42^{\circ} \mathrm{C}$ em banho-maria por 50 segundos e posteriormente incubado, novamente, no gelo por 2 minutos. Foi adicionado $450 \mu \mathrm{L}$ de meio SOC (SAMBROOK et al., 1989) a temperatura ambiente e incubado em seguida por 2 horas a $37^{\circ} \mathrm{C}$ sob agitação de $200 \mathrm{rpm}$.

As células competentes transformadas foram cultivadas em placas de Petri contendo meio LB sólido, acrescido de ampicilina, X-Gal e IPTG (todos em concentração final de $100 \mu \mathrm{g} \mathrm{mL}^{-1}$ ). As células foram incubadas em estufa a $37^{\circ} \mathrm{C}$ por 16 horas, e após este período, as placas foram armazenadas a $4^{\circ} \mathrm{C}$ para facilitar a visualização e a seleção das colônias azuis/brancas.

\subsubsection{Seleção e estoque dos clones}

Apenas as colônias brancas, as quais devem conter vetor/inserto, foram selecionadas para a continuação do trabalho. As colônias foram coletadas com auxilio de palitos estéreis e 
transferidas para microplaca Deep - Well com 96 poços, contendo $1 \mathrm{~mL}$ de meio Circle Grow (Bio 101), acrescido com ampicilina $\left(100 \mu \mathrm{g} \mathrm{mL}^{-1}\right)$. A placa foi selada com filme adesivo e cada poço foi perfurado com agulha estéril para a aeração da bactéria. Os clones foram incubados sob agitação orbital (shaker) a $320 \mathrm{rpm}, 37^{\circ} \mathrm{C}$, por 22 horas.

Após o crescimento, foi transferido $100 \mu \mathrm{L}$ de células para placa estéril contendo $100 \mu \mathrm{L}$ de glicerol $50 \%$. A placa foi selada e as células estocadas a $-80^{\circ} \mathrm{C}$.

\subsubsection{Extração e quantificação do DNA plasmidial}

Após a estocagem dos clones, foi feita a extração do DNA plasmidial das culturas (BIRNBOIM; DOLY, 1979), segundo protocolo modificado. A placa foi centrifugada a 4.000 $\mathrm{rpm}$, por 6 minutos, a $20^{\circ} \mathrm{C}$. O meio de cultura foi descartado e verificou-se a presença de precipitado. A placa foi mantida invertida sobre papel absorvente por 5 minutos. Em cada cavidade foi adicionado $240 \mu \mathrm{L}$ de solução GTE (Glicose $50 \mathrm{mM}$; Tris-HCl $25 \mathrm{mM}, \mathrm{pH} 8,0$; EDTA $10 \mathrm{mM}, \mathrm{pH} 8,0$ ) e agitou-se vigorosamente por 2 minutos. $\mathrm{O}$ material foi centrifugado $4.000 \mathrm{rpm}$, por 6 minutos, a $20^{\circ} \mathrm{C}$, o sobrenadante descartado e a placa foi novamente invertida sobre o papel absorvente por 5 minutos. As células foram ressuspendidas em $80 \mu \mathrm{L}$ de solução GTE e agitou-se por 2 minutos. Em uma microplaca de fundo U (tipo Elisa) foi adicionado 2,5 $\mu \mathrm{L}$ de RNAse em cada cavidade $\left(10 \mathrm{mg} \cdot \mathrm{mL}^{-1}\right)$ e $60 \mu \mathrm{L}$ de cada suspensão de células. Adicionouse $60 \mu \mathrm{L}$ de $\mathrm{NaOH} / \mathrm{SDS}(\mathrm{NaOH} 0,2 \mathrm{~N}$; SDS 1\%), inverteu-se a placa por 10 vezes, incubou-se por 10 minutos, a temperatura ambiente e centrifugou-se a $4.000 \mathrm{rpm}$, por 30 segundos, a $20^{\circ} \mathrm{C}$. Foram adicionados $60 \mu \mathrm{L}$ de acetato de potássio 3M, pH 4,8 gelado $(29,44$ g de KOAc foram dissolvidos em $60 \mathrm{~mL}$ de água e adicionados 11,5 mL de ácido acético glacial; o volume foi completado para $100 \mathrm{~mL}$ com água ultrapura Milli-Q autoclavada) e novamente foi feita mistura por inversão. A placa contendo os plasmídeos foi incubada por 10 minutos a temperatura ambiente, centrifugada a $4.000 \mathrm{rpm}$, por 30 segundos, a $20^{\circ} \mathrm{C}$ e incubada em estufa a $90^{\circ} \mathrm{C}$ por exatos 30 minutos. Após esse período as amostras foram colocadas em gelo por 10 minutos e centrifugadas a $4.000 \mathrm{rpm}$, por 4 minutos, a $20^{\circ} \mathrm{C}$. Todo o volume das amostras foi transferido para microplaca com filtro (PVDF - $0.2 \mu \mathrm{m}$ - Millipore) e centrifugado a $4.000 \mathrm{rpm}$, por 4 minutos, a $20^{\circ} \mathrm{C}$. Adicionou-se ao material filtrado $110 \mu \mathrm{L}$ de isopropanol absoluto, a solução foi 
misturada por inversão, e o material foi centrifugado a $4.000 \mathrm{rpm}$, por 45 minutos, a $20^{\circ} \mathrm{C}$. Depois de centrifugado o sobrenadante foi descartado e o precipitado foi lavado com $200 \mu \mathrm{L}$ de etanol $70 \%$ gelado, e posteriormente, foi centrifugado a $4.000 \mathrm{rpm}$, por 5 minutos, a $20^{\circ} \mathrm{C}$. O sobrenadante foi descartado e a placa foi centrifugada invertida sobre o papel absorvente a 900 $\mathrm{rpm}$, por 3 minutos, a $20^{\circ} \mathrm{C}$. As amostras foram deixadas por 1 hora, a temperatura ambiente para secagem e ressuspendidas em $40 \mu \mathrm{L}$ de água ultrapura Milli-Q autoclavada. A placa foi incubada por 16 horas a temperatura ambiente, para solubilização do material e armazenada a $-20{ }^{\circ} \mathrm{C}$.

Para verificação e quantificação da extração do DNA plasmidial, uma alíquota de $2 \mu \mathrm{L}$ de DNA adicionada de $3 \mu \mathrm{L}$ de tampão de carregamento, foi aplicada em gel de agarose $1 \%$. Marcador de peso molecular pGEM (Applied Biosystems) foi aplicado para comparação de intensidade do material. O gel foi documentado através do programa "Multi Analyst" do Flúor$\mathrm{S}^{\mathrm{TM}}$ Multimager (BioRad, Hercules, California, E.U.A.). O produto purificado foi armazenado a $-20^{\circ} \mathrm{C}$ até posterior utilização.

\subsubsection{PCR de inserto}

Para confirmação da presença de inserto no vetor foram realizadas reações de PCR de 15 clones de cada amostra de solo (BITPA; BIADJ; MITPA e MIADJ). A reação foi feita da seguinte maneira: $2,5 \mu \mathrm{L}$ de tampão para PCR 10X; 0,2 mM de cada dNTP; $3 \mathrm{mM}$ de $\mathrm{MgCl}_{2} ; 1,5$ U de Platinum Taq DNA Polimerase (Invitrogem); 10 ng de DNA; 5 pmol de primer fD1 (5'AGAGTTTGATCCTGGCTCAG-3') e rD1 (5'-AAGGAGGTGATCCAGCC-3') (WEISBURG et al., 1991); água Milli-Q esterilizada para um volume final de $25 \mu \mathrm{L}$. A reação foi feita em termociclador (GeneAMP PCR System 9700 - Applied Biosystems) nas seguintes condições: $94^{\circ} \mathrm{C}$ por 4 minutos, 25 ciclos com desnaturação a $94^{\circ} \mathrm{C}$ por 1 minuto, anelamento a $55^{\circ} \mathrm{C}$ por 30 segundos, extensão a $72^{\circ} \mathrm{C}$ por 2 minutos e extensão final a $72^{\circ} \mathrm{C}$ por 10 minutos. Ao final do programa a reação permaneceu no termociclador a $4{ }^{\circ} \mathrm{C}$. A reação de $\mathrm{PCR}$ foi verificada em gel de agarose $1 \%$, utilizando como padrão de tamanho de DNA o marcador molecular 1 kb Plus DNA Ladder $^{\mathrm{TM}}$ (Invitrogen Life Technologies, São Paulo, Brasil). O gel foi documentado através do programa "Multi Analyst” do Flúor-S ${ }^{\mathrm{TM}}$ Multimager (BioRad, Hercules, California, E.U.A.). 


\subsubsection{PCR de sequenciamento e precipitação}

Para cada uma das amostras de solo (BITPA; BIADJ; MITPA e MIADJ) foram seqüenciados 288 clones. A reação foi feita em microplaca de 96 amostras da seguinte maneira: 200 ng de DNA plasmidial; $2 \mu \mathrm{L}$ de DYEnamic (DYEnamic ET Terminator Cycle Sequencing Kit, Amersham, Biosciences GE); $1 \mu \mathrm{L}$ de primer a 5 pmol fD1 (5'AGAGTTTGATCCTGGCTCAG-3'); $3 \mu \mathrm{L}$ de buffer de diluição 2,5X (400 mM Tris-HCl pH $9.0 ; 10 \mathrm{mM} \mathrm{MgCl} 2$ ) e água Milli-Q esterilizada para um volume final de $10 \mu \mathrm{L}$. A reação foi feita em termociclador nas seguintes condições: 30 ciclos com desnaturação a $95^{\circ} \mathrm{C}$ por 20 segundos, anelamento a $55^{\circ} \mathrm{C}$ por 15 segundos, extensão a $60^{\circ} \mathrm{C}$ por 60 segundos. Ao final do programa as amostras permaneceram no termociclador a $4^{\circ} \mathrm{C}$.

Após a reação, as amostras foram precipitadas para o sequenciamento conforme instrução do fabricante. Adicionou-se $2 \mu \mathrm{L}$ de solução acetato de sódio/EDTA e $60 \mu \mathrm{L}$ de etanol absoluto. O material foi misturado em vortex e centrifugado a $4000 \mathrm{rpm}$, por 45 mimutos a temperatura ambiente. O sobrenadante foi removido e a placa foi centrifugada invertida, sob papel absorvente, a $900 \mathrm{rpm}$, por 30 segundos a temperatura ambiente. Adicionou-se $150 \mu \mathrm{L}$ de etanol $70 \%$ e centrifugou-se a $4000 \mathrm{rpm}$, por 15 minutos a temperatura ambiente. O sobrenadante foi removido e a placa foi centrifugada invertida, sob papel absorvente, a $900 \mathrm{rpm}$, por 30 segundos a temperatura ambiente. As amostras foram secas no termociclador a $40^{\circ} \mathrm{C}$, por 10 minutos.

As amostras foram ressuspendidas em $10 \mu \mathrm{L}$ de Hi-Di Formamide (Applied Biosystems) e agitadas em vortex por 10 minutos, temperatura ambiente. O sequenciamento dos clones foi realizado no sequenciador capilar automático modelo ABI PRISM 3100 Genetic Analyzer Applied Biosystems/HITACHI. 


\subsubsection{Análise das seqüências}

A verificação das seqüências foi realizada com base nos eletroferogramas gerados pelo software Sequencing Analysis 3.0. Essas seqüências foram editadas pelos programas Phred/Phrap/Consed em sistema operacional Linux (EWING; GREEN, 1998; EWING et al., 1998; GORDON et al., 1998), para remoção de seqüências que apresentaram baixa qualidade. O nível de exigência mínima foi de 400 bases com qualidade Phrap acima de 20 ( 1 erro a cada 100 bases lidas), para posteriores análises. A análise comparativa das bibliotecas foi realizada através do programa Library Compare do site Ribosomal Database Project II (RDP II) versão 9.52 (http://rdp.cme.msu.edu). O RDP possui um sistema de classificação taxonômica (RDP Hierarchy) que segue a proposta do Manual Bergeys (GARRITY et al., 2004) no qual os principais níveis taxonômicos são: Domínio, Filo, Classe, Ordem, Família, Gênero e Espécie.

O número de Unidades Taxonômicas Operacionais (UTOs) foi determinado utilizando-se o programa DOTUR (Distance Based OTU and Richness Determination) (SCHLOSS et al., 2005), considerando-se uma distância evolutiva de 0,03 através do algoritmo de furthest

neighbor. Para tanto, as seqüências foram alinhadas utilizando o programa Clustal X 1.83 (THOMPSON et al., 1997). O alinhamento foi utilizado para se calcular uma matriz de distância evolutiva através do DNADIST, programa do pacote PHYLIP 3.63, usando o algoritmo de Jukes e Cantor.

As estimativas de riqueza (ACE, Chao1, Jackknife, Bootstrap e rarefação) e as medidas de diversidade de UTOs (índices de Shannon e Simpson) foram feitas utilizando o programa EstimateS 8.0 (purl.oclc.org/estimates) e DOTUR. Este último programa foi empregado apenas para o método da rarefação. 


\subsection{RESULTADOS E DISCUSSÃO}

\subsubsection{Coleta e caracterização dos solos}

As amostras de solos Terra Preta Antropogênica e os respectivos solos adjacentes coletados em duas regiões: (a) Amazônia Central - Amazonas, Lagoa Balbina; (b) Amazônia Oriental - Pará, Floresta Nacional de Caxiuanã - sítio arqueológico Mina I foram coletadas em duas profundidades 10 e $20 \mathrm{~cm}$, por normalmente apresentarem maior riqueza de diversidade bacteriana, conforme descrito por Tsai et al. (2003). Após a coleta foram realizadas análises das características químicas das amostras de solos (Tabela 1). Através da análise química as amostras de solos de TPA coletadas na região da Lagoa Balbina e no sito Mina I apresentaram valores de pH mais elevados quando comparados com solos adjacentes (Tabela 1), confirmando os valores elevados encontrados por Lima et al. (2002) e por Falcão; Borges (2006). Foram observados também altos teores de cálcio e fósforo e baixa saturação por alumínio, conforme descrito anteriormente por KERN; KÄMPF (1989); LEHMANN et al. (2002). Outra característica observada nos solos TPAs foi o alto valor da capacidade de troca catiônica (CTC), quando comparados com os solos adjacentes.

Estas análises quimicas confirmaram as características do solo já descritas para a Terra Preta Antropogênica, evidenciando que estes solos possuem elevada fertilidade.

\subsubsection{Extração de DNA genômico total do solo}

As extrações de DNA genômico total dos solos foram realizadas com três repetições para cada amostra de solo: Terra Preta Antropogênica e os respectivos solos adjacentes da região Amazônia Central - Lagoa Balbina e região Amazônia Oriental - Caxiuanã, utilizando-se o Kit Power Soil DNA Isolation (MOBio). O DNA das amostras de solo foi extraído com sucesso a partir da utilização do Kit, obtendo alta quantidade e ótima qualidade de DNA. A concentração e qualidade foram determinadas em gel de agarose $1 \%$, resultando em uma concentração de aproximadamente $100 \mathrm{ng}$ por microlitro. 


\subsubsection{Amplificação e purificação do gene 16S rRNA}

Os DNAs obtidos foram amplificados por PCR com oligonucleotídeos específicos para o gene 16S rRNA para o Domínio Bacteria fD1 e rD1. Os produtos de PCR amplificados geraram fragmentos de DNA de aproximadamente $1.500 \mathrm{pb}$. Todas as reações de amplificação geraram produtos de PCR suficiente para a realização da clonagem. Em todas as reações foram feitos controles negativos sem DNA (Figura 9 a). Os produtos amplificados foram purificados através do Kit GFX PCR DNA and Gel Band Purification (Amersham Biosciences). Na Figura 9 b podese visualizar os produtos de PCR purificados, em condições ideais para a construção das bibliotecas genômicas.

No presente trabalho, o número de ciclos nas reações de PCR foi diminuído de 30 para 25 ciclos para minimizar a formação de moléculas quimeras, uma vez que é conhecido a formação dessas moléculas em amplificações do gene 16S rRNA quando se utiliza uma mistura de DNA genômico de várias espécies diferentes (WANG; WANG, 1997).

As moléculas quimeras são formadas por seqüências de mais de uma bactéria. Quando as seqüências são comparadas com banco de dados, poderiam ser identificadas como uma espécie nova não classificada, sugerindo a presença de um organismo inexistente. A principal causa da formação de moléculas quimeras é a presença de fitas simples de DNA terminadas prematuramente, especialmente nos ciclos finais da reação da PCR, que reanelam a uma fita de DNA diferente concluindo a amplificação (PAABO et al., 1992). WANG; WANG (1997) realizaram estudos in vitro a partir de uma mistura de DNA genômicos de oito diferentes espécies de actinomicetos para minimizar a formação dessas moléculas, mostrando que a taxa de formação de moléculas quimeras foi de $32 \%$ para uma reação de PCR com 30 ciclos, caindo para $12 \%$ para reação com 25 ciclos. 

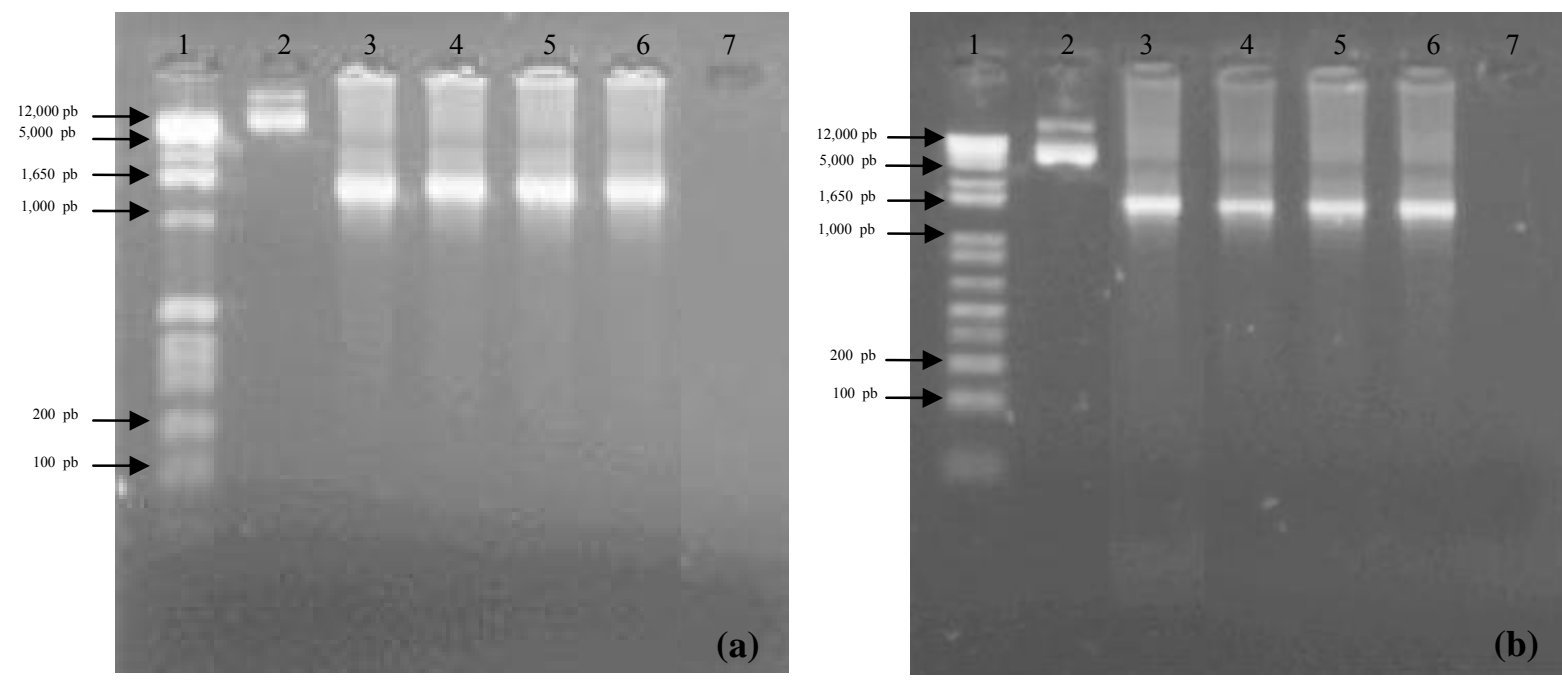

Figura 9 (a) - Resultado da amplificação do gene 16S rRNA. Perfil eletroforético em gel de Agarose 1\% contendo Brometo de etídeo. 1 - Padrão de tamanho molecular 1 kb Plus DNA Ladder (Invitrogen); 2 - Padrão de concentração 200 ng; 3 - solo TPA Lagoa Balnina (BITPA); 4 - solo adjacente Lagoa Balbina (BIADJ); 5 - solo TPA Caxiuanã - Mina I (MITPA); 6 - solo adjacente Caxiuanã - Mina I (MIADJ) e 7 - amostra controle negativo.

Figura 9 (b) - Resultado da purificação do gene 16S rRNA. Perfil eletroforético em gel de Agarose 1\% contendo Brometo de etídeo. 1 - Padrão de tamanho molecular 1 kb Plus DNA Ladder (Invitrogen); 2 - Padrão de concentração 200 ng; 3 solo TPA Lagoa Balnina (BITPA); 4 - solo adjacente Lagoa Balbina (BIADJ); 5 solo TPA Caxiuanã - Mina I (MITPA); 6 - solo adjacente Caxiuanã - Mina I (MIADJ) e 7 - amostra controle negativo. 


\subsubsection{Construção da Biblioteca 16S rRNA}

Foram construídas quatro bibliotecas a partir dos produtos de PCR, utilizando o vetor pGEM-T, sendo uma biblioteca de solo Terra Preta - Lagoa Balbina (BITPA); uma biblioteca de solo Adjacente - Lagoa Balbina (BIADJ); uma biblioteca da Floresta Nacional de Caxiuanã Mina I Terra Preta (MITPA) e uma biblioteca da Floresta Nacional de Caxiuanã - Mina I Adjacente (MIADJ). Para cada amostra de solo amplificada com oligonucleotídeos específicos para o gene 16S rRNA - fD1 e rD1 foram selecionados 288 clones transformantes. No total foram selecionados 1152 clones (12 placas de 96 clones) divididos entre as quatros bibliotecas, criando-se uma nomenclatura para organizar e identificar as bibliotecas gênicas. A nomenclatura foi feita através da identificação do local realizado das amostras BI (Lagoa Balbina) e MI (Mina I), do tipo de solo TPA (Terra Preta Antropogênica) e ADJ (Adjacente) e da placa 1 a 3 . A nomenclatura dos 96 clones em cada placa foi feita indicando as linhas de $\mathrm{A}$ a $\mathrm{H}$ e as coluna de 1 a 12. Por exemplo, a amostra BITPA2A01 corresponde ao local BI, solo TPA, placa 2, linha A coluna 01 .

Para confirmação da inserção dos fragmentos no vetor de clonagem, foram realizadas reações de PCR utilizando-se oligonucleotídeos específicos para o gene 16S rRNA - fD1 e rD1, como descrito anteriormente, confirmando a presença dos fragmentos nos tamanhos desejados ao redor de $1500 \mathrm{pb}$. O perfil da amplificação dos fragmentos obtidos indicou que $100 \%$ das amostras avaliadas continham o fragmento correspondente ao gene 16S rRNA (Figura 10). 


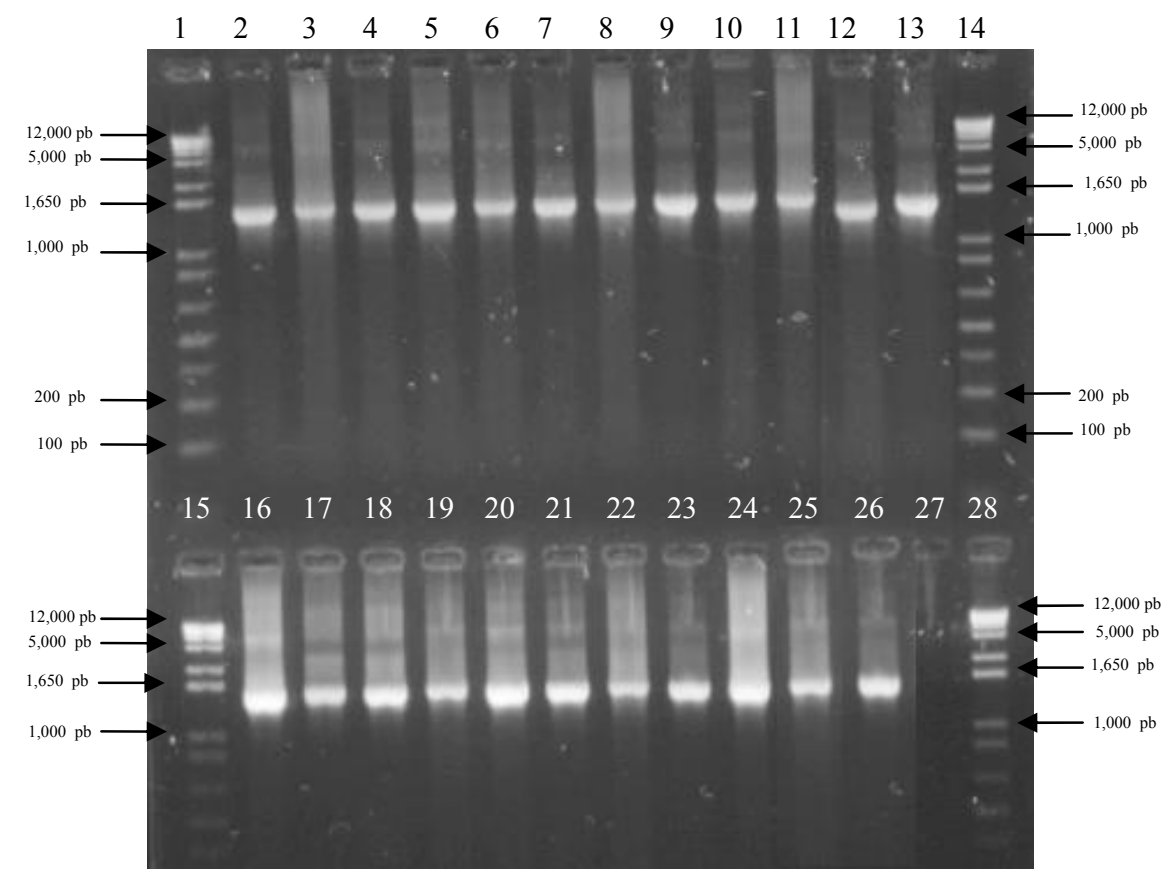

Figura 10 - Reação de PCR para confirmação da inserção dos fragmentos no vetor de clonagem. 1 - Padrão de tamanho molecular 1 kb Plus DNA Ladder (Invitrogen); 2 a 7 - Clones aleatórios da biblioteca BITPA; 8 a 13 - Clones aleatórios da biblioteca BIADJ; 14 - Padrão de tamanho molecular 1 kb Plus DNA Ladder (Invitrogen); 15 - Padrão de tamanho molecular 1 kb Plus DNA Ladder (Invitrogen); 16 a 21 Clones aleatórios da biblioteca MITPA; 22 a 26 clones aleatórios da biblioteca MIADJ; 27 - Amostra controle negativo e 28 - Padrão de tamanho molecular 1 kb Plus DNA Ladder (Invitrogen). 


\subsubsection{Sequenciamento parcial dos clones e análise das seqüências}

A extração do DNA plasmidial e a reação de sequenciamento dos clones foram feitas em larga escala, 96 amostras por placa. Um total de 1152 clones de 16S rRNA foram seqüenciados e analisados, sendo 288 pertencentes a cada biblioteca:
a) solo TPA Lagoa Balbina (BITPA);
b) solo adjacente Lagoa Balbina (BIADJ);
c) solo TPA Caxiuanã (MITPA);
d) solo adjacente Caxiuanã (MIADJ).

Todos os clones foram seqüenciados utilizando o oligonucleotídeo fD1. O sequenciamento parcial é justificado uma vez que o objetivo é avaliar a diversidade e não realizar um estudo evolutivo detalhado.

Após os processos de análises da qualidade das seqüências pelos programas Phred/Phrap/Consed em sistema operacional Linux obteve-se 198, 265, 278 e 239 clones para o estudo de BITPA, BIADJ, MITPA e MIADJ, respectivamente (Tabela 2), resultando em 980 clones. O tamanho médio das seqüências dos clones com qualidade Phred acima de 20 foi de aproximadamente 550 pares de bases em cada biblioteca. O número de Unidades Taxonômicas Operacionais (UTOs) foi determinado utilizando-se o programa DOTUR (Distance Based OTU and Richness Determination) (SCHLOSS et al., 2005), considerando-se uma distância evolutiva de 0,03 através do algoritmo de furthest neighbor. O número de UTOs encontradas na biblioteca BITPA foram 119, na biblioteca BIADJ 134, na biblioteca MITPA 147 e na biblioteca MIADJ 141 (Tabela 2). Para tanto, as seqüências foram alinhadas utilizando o programa Clustal X 1.83 (THOMPSON et al., 1997). O alinhamento foi utilizado para se calcular uma matriz de distância evolutiva através do DNADIST, programa do pacote PHYLIP 3.63, usando o algoritmo de Jukes e Cantor.

As seqüências geradas após análise utilizando-se o programa DOUTUR resultaram em um total de 541 seqüências. Elas foram comparadas com outras seqüências previamente depositadas no GenBank do National Center for Biotechnology Information (NCBI), utilizando-se a 
ferramenta Basic Local Alignment Search Tool (BLAST) (ALTSCHUL et al, 1990), visando a identificação das amostras. Os resultados da comparação das seqüências obtidas com a análise do BLAST estão apresentados no Anexo A.

Outro tipo de comparação das seqüências obtidas neste trabalho foi através do banco de dados de seqüências de 16S rRNA do banco de dados do RDP II pelo programa Library Compare (Figura 11 e 12) e programa Classifier (Anexo B). As 980 seqüências obtidas a partir da análise através dos programas Phred/Phrap/Consed (Tabela 2) foram comparadas utilizando o banco de dados de seqüências de 16S rRNA do RDP II pelo programa Classifier. A confiabilidade desse programa apresenta os mais altos níveis taxonômicos. Os resultados das comparações obtidos em nível de filo são os mais confiáveis do que aqueles obtidos em qualquer outro nível. Os resultados completos da comparação das seqüências com o programa Classifier são apresentados no Anexo B.

As seqüências que obtiveram uma pontuação de confiabilidade baixa são provavelmente seqüências de genes $16 \mathrm{~S}$ rRNA inéditas e podem indicar a presença de novos organismos nessas amostras de solo que ainda não estão depositadas no bancos de dados. Esses resultados são apresentados no Anexo B. O grande número de seqüências desta natureza encontrado neste estudo ressalta a necessidade dos estudos de diversidade e detecção destes microrganismos.

Tabela 2 - Números totais de clones seqüenciados, válidos e UTOs (Unidades Taxonômicas Operacionais) para análise comparativa com outras seqüências do GeneBank e RDP II.

\begin{tabular}{cccc}
\hline Amostra Biblioteca & Clones seqüenciados & Clones válidos & Número de UTOs \\
\hline BITPA & 288 & 198 & 119 \\
BIADJ & 288 & 265 & 134 \\
MITPA & 288 & 278 & 147 \\
MIADJ & 288 & 239 & 141 \\
Total & 1152 & 980 & 541 \\
\hline BITPA - solo TPA Lagoa Balnina; BIADJ - solo adjacente Lagoa Balbina; MITPA - solo TPA \\
Caxiuanã - Mina I; MIADJ - solo adjacente Caxiuanã - Mina I.
\end{tabular}




\subsubsection{Análise de diversidade das comunidades bacteriana}

Todas as seqüências analisadas pertencem ao Domínio Bacteria com 100\% de confiança. Em todas as bibliotecas, o maior número de seqüências identificadas foi de microrganismos nãocultiváveis ou não-conhecidos. No entanto, essas seqüências apresentam algum grau de similaridade com seqüências de $16 \mathrm{~S}$ rRNA de bactérias que estão no banco de dados, porém ainda não foram classificadas. Geralmente essas seqüências provem de análises de amostras ambientais semelhantes as que foram realizadas nesse trabalho. Com isso reforça a idéia de que o mundo microbiano ainda é pouco conhecido (Tabela 3).

Os microrganismos não-conhecidos predominaram em todas as bibliotecas, representando 41,6 \% das seqüências de BITPA (Figura 11 - A), 68,3 \% das seqüências de BIADJ (Figura 11 B), 84,8\% das seqüências de MITPA (Figura 12 - A) e 47,7 \% das seqüências de MIADJ (Figura 12 - B). Em MITPA, esta distribuição mostrou evidências de diferenças de diversidade bacteriana entre os solos, havendo maior número de microrganismos desconhecidos/não cultiváveis em solo de Terra Preta Antropogênica quando comparados com solos adjacentes. Este resultado corrobora com os resultados obtidos por TSAI et al. (2003) e KIM et al. (2007) em outros solos de TPA.

O domínio Bacteria, é composto de 23 filos determinados com base nas seqüências do 16S rRNA. Alguns destes filos consistem em uma única ou algumas poucas espécies enquanto outros filos como: Proteobacteria, Firmicutes e Actinobacteria incluem milhares de espécies as quais correspondem a 90-95\% de todas as espécies de bactérias conhecidas (NUNES, 2006).

Dentro do domínio Bacteria, o filo mais predominante na biblioteca BITPA foi Firmicutes, representando aproximadamente $37,1 \%$ do total de seqüências analisadas (Figura 11 A). Já na biblioteca BIADJ o filo mais predominante foi Proteobacteria, representando aproximadamente $15,1 \%$ do total de seqüências analisadas (Figura $11 \mathrm{~B}$ ). Os resultados da biblioteca MITPA apresentaram predominância do filo Proteobacteria, representando $6,5 \%$ das seqüências analisadas (Figura 12 A) e na biblioteca MIADJ o filo Acidobacteria, representando 27,2\% das seqüências analisadas (Figura 12 B). 
$\mathrm{Na}$ biblioteca BITPA os demais filos em destaque foram Proteobacteria representando uma freqüência de 9,6\%, Verrucomicrobia 5,6\%, Acidobacteria 2,5\%, Gemmatimonadetes 2,5\%, Actinobacteria $0,5 \%$ e Nitrospira 0,5\% (Figura 11 - A). Por outro lado, na biblioteca BIADJ destacaram-se os filos Acidobacteria 12,5\%, Firmicutes 2,3\%, Nitrospira $1,1 \%$ e Verrucomicrobia 0,8\% (Figura 11 - B). Na biblioteca MITPA os filos apresentados foram Acidobacteria 4,7\%, Firmicutes 1,4\%, Nitrospira 1,1\%, Planctomycetes 1,1\% e Verrucomicrobia 0,4\% (Figura 12 - A). Contudo, na biblioteca MIADJ verificou-se a presença dos filos Proteobacteria 14,2\%, Firmicutes 3,8\%, Verrucomicrobia 3,8\%, Nitrospira 1,3\%, Planctomycetes 1,3\%, Actinobacteria 0,4\% e Gemmatimonadetes 0,4\% (Figura 12 - B).

Tabela 3 - Filos bacterianos encontrados em solos da região Amazônica Central e Oriental comparadas com o banco de dados de seqüências de 16S rRNA do RDP II através do programa Library Compare e números de clones representantes em cada filo encontrados em cada biblioteca.

\begin{tabular}{cccccc}
\hline FILO & BITPA & BIADJ & MITPA & MIADJ & TOTAL \\
\hline Acidobacteria & 5 & 33 & 13 & 65 & 116 \\
Actinobacteria & 1 & - & - & 1 & 2 \\
Firmicutes & 73 & 6 & 4 & 9 & 92 \\
Gemmatimonadetes & 5 & - & - & 1 & 6 \\
Incertae sedis* & 1 & - & 1 & - & 2 \\
Nitrospira & 1 & 3 & 3 & 3 & 10 \\
Planctomycetes & - & - & 3 & 3 & 6 \\
Proteobacteria & 19 & 40 & 18 & 34 & 111 \\
Verrucomicrobia & 11 & 2 & 1 & 9 & 23 \\
Não Classificadas & 82 & 181 & 235 & 114 & 612 \\
Total & 198 & 265 & 278 & 239 & 980
\end{tabular}

BITPA - solo TPA Lagoa Balnina; BIADJ - solo adjacente Lagoa Balbina; MITPA - solo TPA Caxiuanã - Mina I; MIADJ - solo adjacente Caxiuanã - Mina I; * Genera insertae sedis inclui membros do candidate a filo WS3 e OP10; (-) clone não encontrado. 
Comparando-se as seqüências obtidas de amostras solo TPA e solo adjacente da região da Amazônia Central - Lagoa da Balbina, observou-se no solo TPA maior riqueza bacteriana quando comparado com solo adjacente. Nas amostras de solos TPA foram detectados 7 filos enquanto que em solo adjacente foram detectados 5 filos. Os dois filos presentes em TPA e ausentes em solo adjacente foram Actinobacteria e Gemmatimonadetes (Figura 11 - A e B).

No caso das bibliotecas de solos da Amazônia Oriental, Floresta Nacional de Caxiuanã sítio arqueológico Mina I, observou-se o oposto da riqueza bacteriana de solos da Lagoa Balbina. Neste caso, observou-se maior riqueza bacteriana em solo adjacente quando comparada com o solo TPA. Nas amostras de solo adjacente foram detectados 8 filos enquanto que em solo TPA foram detectados 6 filos. Os dois filos presentes em solo adjacente, porém, ausentes em TPA foram Actinobacteria e Gemmatimonadetes (Figura 12 - A e B).

Representantes do filo Gemmatimonadetes não foram encontrados nos estudos realizados por Kim et al. (2007), em solos de Terra Preta e solos de floresta Amazônica. No entanto, no presente trabalho obtivemos seqüências deste filo tanto em Terra Preta (BITPA) quanto em solo adjacente (MIADJ). 

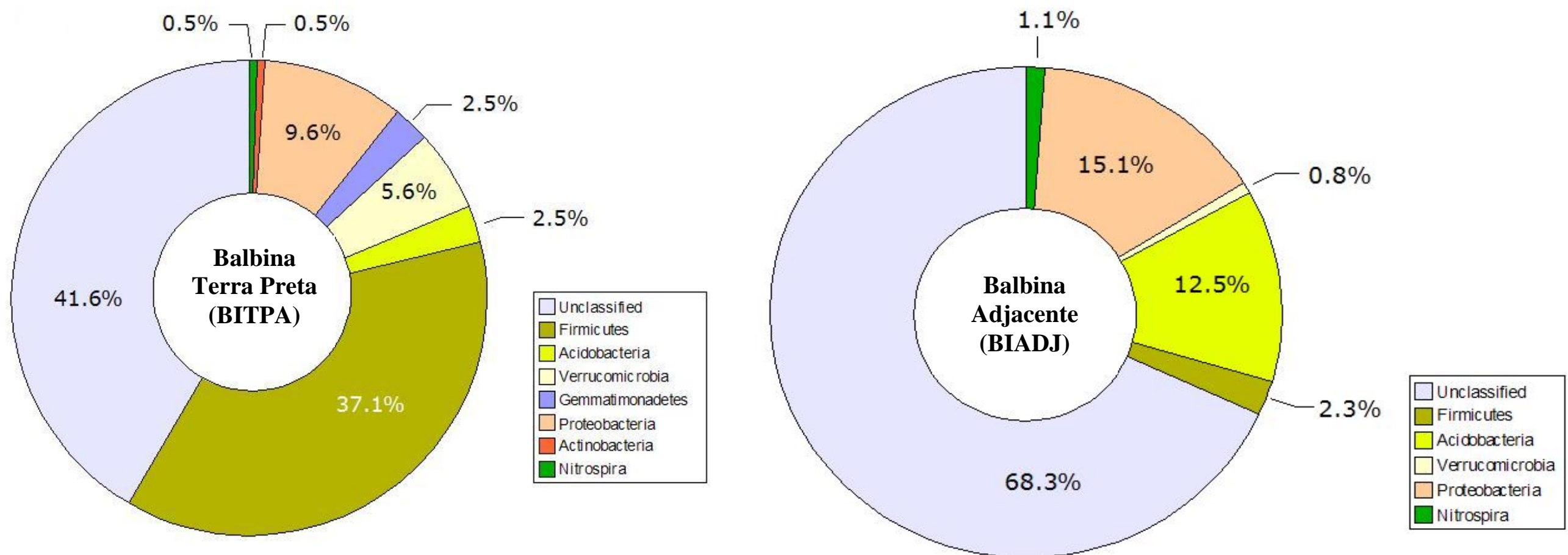

A

Figura 11 - Diversidade bacteriana encontrada nos solos TPA e adjacentes (Lagoa Balbina) nos clones 16S rRNA com base na afiliação filogenética do RDP II pelo programa Library Compare.

A - Solo Terra Preta Antropogênica - região da Amazônia Central, Lagoa da Balbina;

B - Solo adjacente - região da Amazônia Central, Lagoa da Balbina. 

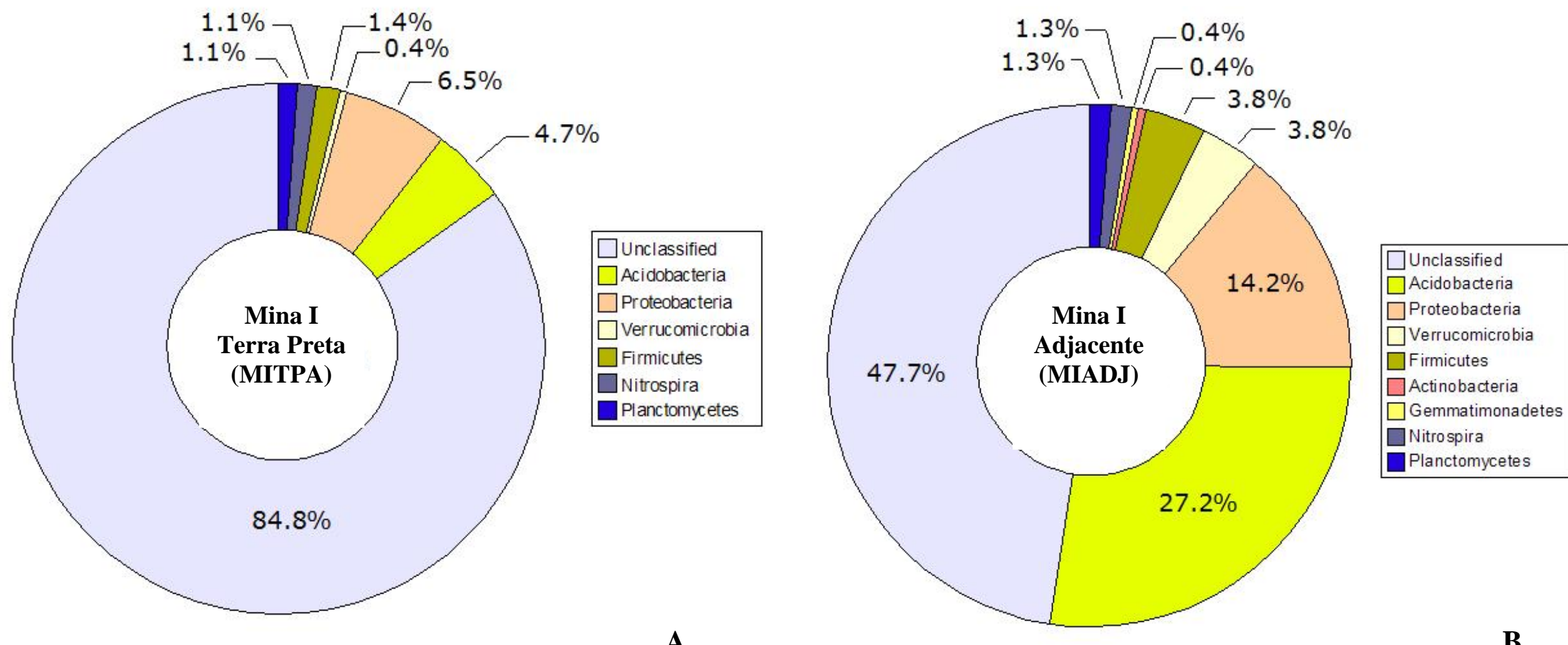

A

Figura 12 - Diversidade bacteriana encontrada nos solos TPA e adjacentes (Caxiuana - Mina I) nos clones 16S rRNA com base na afiliação filogenética do RDP II pelo programa Library Compare.

A - Solo Terra Preta Antropogênica - região da Amazônia Oriental, Floresta Nacional de Caxiuanã, Sítio Mina I; B - Solo adjacente - região da Amazônia Oriental, Floresta Nacional de Caxiuanã, Sítio Mina I. 
Embora ainda pouco conhecido, o filo Acidobacteria vem sendo encontrado em análises do gene 16S rRNA de amostras ambientais marinhas, terrestres, animais, aerossóis e fontes termais (BARNS et al., 2007). A maioria das seqüências dos organismos que compõe este filo Acidobacteria tem origem de amostras ambientais amplamente distribuídas pelo planeta. Os estudos realizados com organismos deste filo sugerem que estes microrganismos são componentes ecológicos significativos em diversos ecossistemas, particularmente em comunidades de solo (HUNGENHOLTZ et al, 1998; DUNBAR et al., 2002). HIRASHI et al., (1995) através de análises do gene 16S rRNA propuseram que este agrupamento fosse denominado Acidobacteria, possuindo atualmente apenas 3 representantes cultiváveis: Acidobacterium capsulatum, Holophaga foetida e Geotrix fermentans. A. capsulatum foi o primeiro representante desse filo, sendo um organismo heterotrófico, aeróbico e moderamente acidofílico (HIRASHI et al., 1995). H. foetida é um organismo anaeróbico que fermentam compostos aromáticos (LIESACK et al., 1994). G. fermentans um organismo anaeróbico que fermentam compostos de acetato (LONERGAN et al., 1996). Seqüências do gene 16S rRNA desse grupo de bactérias foram encontradas em várias localidades do mundo como por exemplo na Ásia (MITSUI et al., 1997), na Austrália (LIESACK; STACKEBRANDT, 1992), em ambas as Américas (BORNEMAN et al., 1996; BORNEMAN; TRIPLETT, 1997) e na Europa (FELSKE et al., 1998; HACKL et a., 2004). Bactérias deste filo devem ter importância ecológica significativa, pois são encontradas em abundância nos mais diversos tipos de solo. Neste trabalho, vinte nove seqüências do filo Acidobacteria, (3 de BITPA, 7 de BIADJ, 12 de MITPA e 7 de MIADJ) apresentaram identidade com amostras de sedimentos contaminados com urânio (BARNS et al., 2007).

O filo Acidobacteria indicou presença em todas as bibliotecas realizadas neste trabalho, porém, foi dominante com $12,5 \%$ e $27,2 \%$ das seqüências em amostras de solos adjacentes, BIADJ e MIADJ respectivamente, quando comparadas com amostras de solos Terra Preta Antropogênica. Dados apresentados na análise química dos solos, observamos que solos adjacentes apresentam pH ácido de 3,7 na amostra BIADJ e 4,0 na amostra MIADJ (Tabela 1). Essa característica justifica a predominância do filo Acidobacteria nos solos estudos. Kim et al. (2007) observaram a predominância do filo Acidobacteria em 50\% das seqüências de amostras de solo da floresta amazônica, enquanto que em solos de Terra Preta foram encontradas $30 \%$ das seqüências pertencentes a este filo. 
O filo Proteobacteria constitui-se o maior e mais diverso grupo de bactérias cultivadas, apresentando grande diversidade de morfologia e metabolismo. Possui cinco subdivisões: Alphaproteobacteria, Betaproteobacteria, Deltaproteobacteria, Epsilonproteobacteria e Gammaproteobacteria. Um dos papéis desempenhados por esse grupo está na participação ativa no ciclo do nitrogênio. A dominância de Proteobacteria ocorre geralmente em solos de cultivo (NUSSLEIN; TIEDJE, 1999) e contaminados com metais pesados (SANDAA et al., 2001) que geralmente apresentam um $\mathrm{pH}$ mais elevado em relação ao solo de floresta. A presença deste filo foi observada em todas as bibliotecas realizadas neste trabalho. Pela análise comparativa das seqüências obtidas através do programa RPD o filo Proteobacteria foi constituído por 111 seqüências dentre as bibliotecas BITPA, BIADJ, MITPA e MIADJ, representando freqüência de $9,6 \%, 15,1 \%, 6,5 \%$ e $14,2 \%$ respectivamente. Os dados apresentados neste trabalho estão de acordo com KIM et al. (2007), demonstrando a freqüência do filo Proteobacteria mais elevada em solo adjacente do que em TPA. No presente trabalho, foram identificadas seqüências da subdivisão Alphaproteobacteria, Betaproteobacteria, Deltaproteobacteria e Gammaproteobacteria, com exceção apenas do filo Epsilonproteobacteria.

Para avaliar a relação entre a abundância dos grupos microbianos e as condições de fertilidade do solo, Smit et al. (2001) compararam seus resultados com dados de seqüências do 16S rRNA da literatura. Os resultados mostraram que em solos com alto teor de nutrientes, como matéria orgânica, há uma seleção positiva de bactérias das divisões Alpha e Gammaproteobacteria, bactérias que apresentam altas taxas de crescimento. No entanto, nos solos com baixo teor de nutrientes a porcentagem de Acidobacterium foi mais alta, apresentando bactérias com baixo potencial de crescimento. Através desses resultados Smit et al. (2001), sugeriram que a razão entre Proteobacteria e Acidobacteria serve como um indicativo da condição nutricional do solo. Nas bibliotecas dos dois solos de TPA deste trabalho, encontramos uma razão positiva entre Proteobacteria e Acidobacteria.

Determinou-se também o filo Firmicutes, descrito como bactéria gram-positiva aeróbica e anaeróbica e com baixo teor de G+C. Organismos deste filo apresentam metabolismo caracterizado por homo e heterofermentação e respiração. Organismos pertencentes a este filo como os gêneros Bacillus e Clostridium são bactérias formadoras de esporos e frequentemente 
encontrados em solo (CANHOS; VAZOLLER, 1997). Representantes deste filo, como as bactérias do gênero Bacillus e Clostridium utilizam como estratégia de sobrevivência um crescimento rápido quando há nutrientes em quantidades necessárias. Somente prevalecem em condições com grande quantidade de nutrientes disponíveis em áreas com baixa competição, geralmente são encontrados em ambientes instáveis que estejam passando por transições (ATLAS; BARTHA, 1997). Representantes do filo Firmicutes foram detectados em todas as amostras de solos Terra Preta e respectivos solos adjacentes. Sendo o maior filo, representando 37,1\% das seqüências (Figura 11 A), encontrado na biblioteca de solo Terra Preta da região Lagoa Balbina (BITPA).

O filo Nitrospira representa um grupo de bactérias aeróbicas gram-negativas atuantes no ciclo de nitrogênio em ambientes aquáticos através da oxidação do nitrato, porém, indivíduos desse grupo têm sido encontrados em amostras de solos (GU et al., 2004; DUNBAR et al., 1999). Acredita-se que a atividade deste filo em ambientes aquáticos possa ter atividades semelhantes em amostras de solo (FAORO, 2006). Representantes do filo Nitrospira foram detectados em amostras de solos Terra Preta e respectivos solos adjacentes.

Organismos do filo Verrucomicrobia são bactérias gram-negativas sensíveis a penicilina (HEDLUND et al., 1997). Representantes deste filo foram relatados em ambiente marinho e amostras de solo (HUGENHOLTZ et al., 1998). Organismos deste filo foram encontrados em amostras de solos de Terra Preta e solos adjacentes. Kim et al. (2007) encontraram bactérias desconhecidas ou não-cultiváveis do filo Verrucomicrobia em amostras de solo Terra Preta e em solo de floresta. Representantes deste filo também foram encontradas em solos de pastagem e sob floresta na Amazônia (BORNEMAN; TRIPLETT, 1997).

O filo Actinobacteria é representado por bactérias gram-positivas e com alto teor de $\mathrm{G}+\mathrm{C}$ (GAO; GUPTA, 2005). As Actinobacteria estão distribuídas em ecossistemas aquáticos e terrestres (CHUN et al., 2000) e possuem importante função na decomposição da matéria orgânica e formação de húmus (GOODFELLOW; WILLIAMS, 1983), portanto, são fundamentais para o melhoramento do solo. Bactérias deste filo possuem importante papel na produção de diversos antibióticos. Representantes deste filo foram encontrados em amostras de solo de Terra Preta da 
região Lagoa Balbina (Figura 11 A) e em solos adjacentes da região de Caxiuanã (Figura 12 B). Bactérias deste filo também foram encontradas em amostras de solos de Terra Preta e solos de floresta por KIM et al. (2007).

O filo Gemmatimonadetes possui apenas uma espécie isolada (Gemmatimonas aurantiaca), bactéria gram-negativa, aeróbia e mesofílica encontrada em lamas de um sistema de tratamento de esgoto (ZHANG et al., 2003). Ocorre em diversos ambientes como lodos industriais, sedimentos marinhos e solos (NUNES, 2006). Nete trabalho foram encontrados representantes deste filo em amostras de solos de Terra Preta Lagoa Balbina (Figura 11 A), Terra Preta Caxiuanã (Figura 12 A) e solo adjacente Caxiuanã (figura 12 B). Apenas não foi detectado na amostra de solo adjacente Lagoa Balbina. Representantes deste filo não foram encontrados em estudos de diversidade bacteriana em solo Terra Preta e solo de floresta (Kim et al., 2007).

Foram encontrados em solos de Terra Preta tanto da região na Lagoa Balbina como em Caxiuanã, dois clones que não apresentaram similaridade com nenhuma espécie conhecida de seqüências depositadas no banco de dados do RDP II através do programa Library Compare (Tabela 3). No entanto esses clones apresentaram similaridade com amostras ambientais "insertae sedis”, termo usado para definir um grupo taxonômico desconhecido ou indefinido. O clone BITPA3G08, solo Terra Preta Lagoa Balbina, quando comparado com o banco de dados do RDP II Classifier apresentou similaridade com o filo candidato Genera insertae sedis OP10 (Anexo B), composto por bactérias termofilicas, descrito por Hungenholtz (1998). Esse mesmo clone quando comparado com o banco de dados do NCBI apresentou 92\% identidade com uma amostra de comunidade microbiana de solos da Califórnia (Anexo A). Enquanto, o clone MITPA1E08, solo Terra Preta Caxiuanã, quando comparado com banco de dados do RDP II Classifier apresentou similaridade com o candidato a filo Genera insertae sedis WS3 (Anexo B). Esse mesmo clone quando comparado com banco de dados do NCBI apresentou 97\% de identidade com amostra de comunidade microbiana de caverna vulcânica do Hawai. 


\subsubsection{Estimativa de riqueza e índice de diversidade}

A estimativa o valor máximo de UTOs em um nível filogenético pode ser feita utilizandose métodos estatísticos capazes de extrapolar a relação de UTOs em função do número de seqüências a partir da curva de rarefação ou de métodos não-paramétricos. Neste trabalho a riqueza de filotipos foi verificada por meio do método de rarefação ao nível de $97 \%$ de similaridade e pelos métodos não-paramétricos de estimativa $A C E$ e CHAO1. As curvas de rarefação resultantes foram ascendentes para todas as bibliotecas, não atingindo o platô (Figura 13 e 14). Esses resultados indicam que o número de seqüências $16 \mathrm{~S}$ rRNA não amostrou completamente a riqueza de filotipos das comunidades bacterianas. No entanto, tais curvas revelaram uma diferença sutil da riqueza de filotipos entre as comunidades bacterianas diferenciando-as claramente a partir de 150 seqüências avaliadas, de modo que as bibliotecas BIADJ e MITPA revelaram maior riqueza de UTOs quando comparadas com as bibliotecas BITPA e MIADJ, respectivamente. 


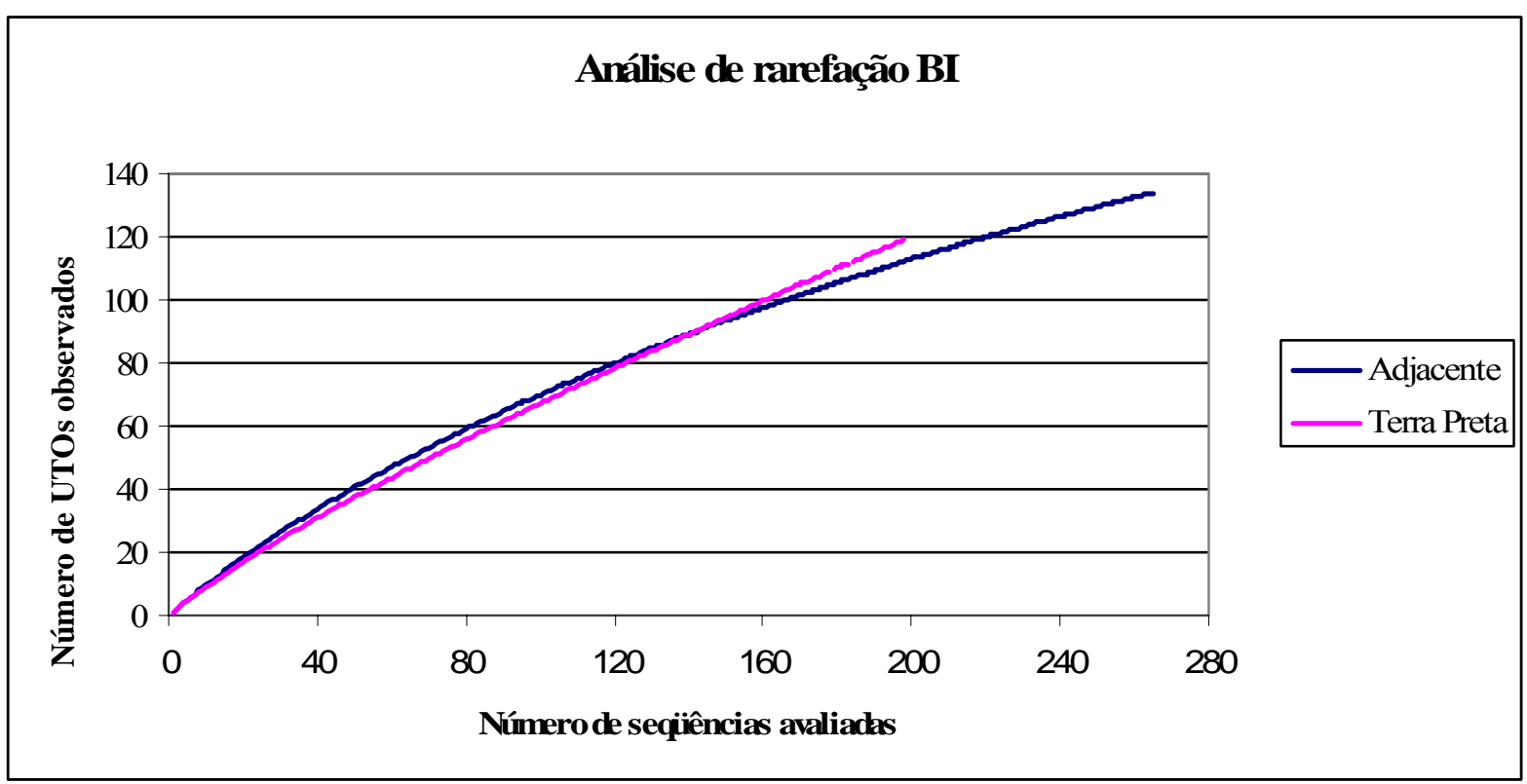

Figura 13 - Curva de rarefação gerada do gene 16S rRNA das bibliotecas de clones de solo Terra Preta Antropogênica e solo Adjacente - região Lagoa Balbina (Amazonas).

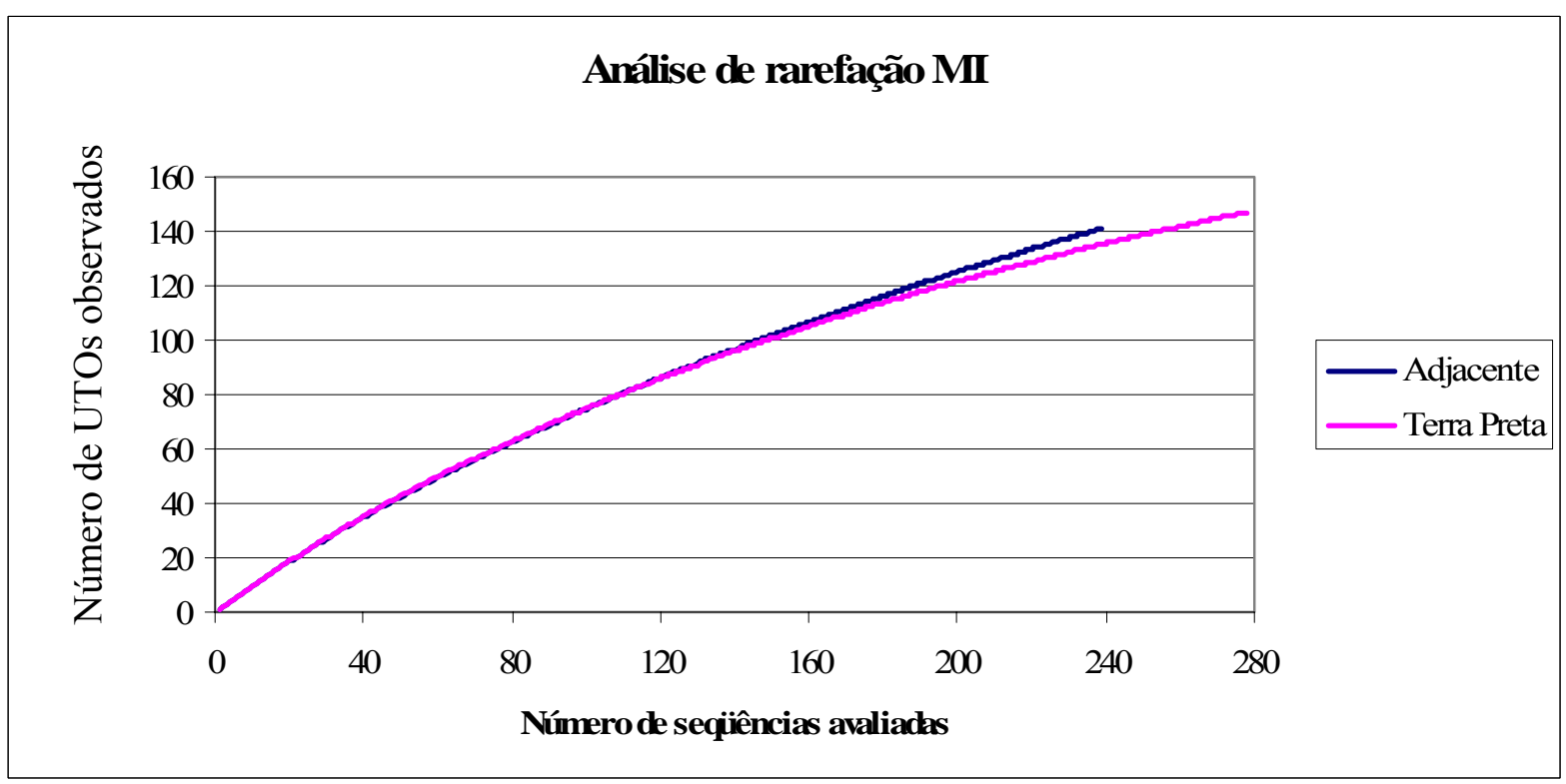

Figura 14 - Curva de rarefação gerada do gene 16S rRNA das bibliotecas de clones de solo Terra Preta Antropogênica e solo Adjacente - região Floresta Nacional de Caxiuanã (Pará). 
Tabela 4 - Estimativas de riqueza de UTOs (Unidades Taxonômicas Operacionais) e índices de diversidade calculados a partir das bibliotecas de 16S rRNA de bactérias de solo Terra Preta Antropogênica e solo adjacente.

\begin{tabular}{|c|c|c|c|c|c|c|c|c|}
\hline \multirow[b]{2}{*}{ Bibliotecas } & \multirow[b]{2}{*}{ NS } & \multirow[b]{2}{*}{ NU } & \multicolumn{4}{|c|}{ Estimativas de riqueza de UTOs } & \multicolumn{2}{|c|}{ Índices de diversidade } \\
\hline & & & ACE & Chao1 & Jackknife & Bootstrap & Simpson & Shannon \\
\hline BITPA & 198 & 119 & 629,4 & 429,4 & 436,2 & 156,5 & 0,0259 & 4,286 \\
\hline BIADJ & 265 & 134 & 284,1 & 237,6 & 284,5 & 167,3 & 0,0102 & 4,608 \\
\hline MITPA & 278 & 147 & 252,8 & 224,0 & 233,1 & 182,1 & 0,0070 & 4,783 \\
\hline MIADJ & 239 & 141 & 373,7 & 291,7 & 324,5 & 179,8 & 0,0082 & 4,705 \\
\hline
\end{tabular}


Os valores obtidos com o índice de diversidade de Simpson revelaram maior diversidade de UTOs nas bibliotecas BIADJ e MITPA se comparado com os valores obtidos para as bibliotecas BITPA e MIADJ, respectivamente (Tabela 4). A mesma relação de diversidade de UTOs foi estabelecida entre as bibliotecas com os valores obtidos pelo índice de diversidade de Shannon. Os valores obtidos através do índice de diversidade de Simpson e Shannon na biblioteca do solo TPA de Caxiuanã - Mina I, corroboram com o trabalho realizado por Kim et al. (2007), que encontraram maior índice de diversidade Simpson $(0,015)$ e Shannon $(5,2)$ em solos de TPA quando comparados com solo de floresta: Simpson 0,34 e Shannon 4,37.

A estimativa da riqueza de UTOs feita pelo Bootstrap corrobora diretamente os valores de diversidade obtidos pelos índices de Simpson e Shannon (Tabela 4). A justificativa para tal relação encontra-se no fato deste estimador basear-se em sub amostragens do conjunto de UTOs utilizado para o cálculo destas medidas de diversidade, bem como na consideração da riqueza de UTOs como um componente da diversidade das bibliotecas. O estimador Jackknife de riqueza de UTOs revelou interpretação inversa à propiciada pelo Bootstrap (Tabela 4). Uma explicação para este resultado encontra-se no uso de UTOs únicas presentes nas bibliotecas para o cálculo da estimativa de riqueza pelo Jackknife. Uma maior probabilidade de ocorrência de UTOs únicas empregadas pelo estimador Jackknife é revelada pela maior freqüência de menores valores percentuais de filotipos nas bibliotecas BITPA e MIADJ (Figura 11 - A e 12 - B) se comparadas às bibliotecas BIADJ e MITPA, respectivamente. Kim et al. (2007) encontraram maior riqueza de UTOs em TPA quando comparados com solo de floresta.

Os valores obtidos com os métodos não-paramétricos $A C E$ e Chao1 para a estimativa da riqueza de UTOs corroboram os valores obtidos com o estimador Jackknife (Tabela 4). 


\section{CONCLUSÕES}

- Com a construção de bibliotecas de clones do gene 16S rRNA a partir dos quatros solos e posterior análise comparativa das seqüências usando o programa RDP II, determinou-se a estrutura das comunidades bacterianas prevalentes nos solos, que possibilitou a identificação dos filos predominantes, sendo que os microrganismos desconhecidos ou não cultivados representaram 41,6\% das seqüências de TPA-Balbina e 68,3\% do seu solo adjacente e 84,8\% das seqüências de TPA-Caxiuanã e 47,7 \% do seu solo adjacente;

- O filo mais predominante nos TPA-Balbina foi Firmicutes, representando 37,1\% dos clones analisados. Por outro lado, nos clones analisados no solo adjacente destacaram-se os filos Proteobacteria 15,1\% e Acidobacteria 12,5\%. Em TPA-Caxiuanã, o filo Proteobacteria também foi o mais representativo $(6,5 \%)$. Na biblioteca do solo adjacente a TPA-Caxiuanã, o filo predominante foi Acidobacteria 27,2\% seguido de Proteobacteria $14,2 \%$.

- $\mathrm{O}$ pH pode ser um dos atributos do solo que pode ter influência direta na diversidade bacteriana dos solos estudados, assim como pode ter efeito uma floresta natural sobre as populações microbianas em seu solo, fato observado na adjacência do solo Terra Preta em Caxiuanã - PA;

- A estimativa da riqueza de UTOs pelo Bootstrap corrobora diretamente os valores de diversidade obtidos pelos índices de Simpson e Shannon. De um modo geral, uma maior probabilidade de ocorrência de UTOs únicas empregadas pelo estimador Jackknife se correlacionou com uma maior freqüência de baixos percentuais de filotipos nas bibliotecas. Os valores obtidos com os métodos não-paramétricos ACE e Chao1 para a estimativa da riqueza de UTOs corroboram com os valores obtidos com o estimador Jackknife;

- Nossos resultados visaram contribuir com o conhecimento sobre a diversidade microbiana em solos de Terra Preta, para a compreensão das funções exercidas pelas comunidades 
microbianas no solo e o conhecimento das suas interações com outros componentes da biodiversidade, além de benefícios econômicos e estratégicos, como a descoberta de microrganismos potencialmente exploráveis nos processos biotecnólogicos. Um desafio é a compreensão da relação entre a composição, abundância e diversidade dos organismos do solo, com a sustentabilidade da fertilidade do solo e a produção agrícola, e os efeitos ambientais, como emissão de gases de efeito estufa e seqüestro do carbono. 


\section{REFERÊNCIAS}

ALTSCHUL, S.F.; GISH, W.; MILLER, W.; MYERS, E.W.; LIPMAN, D.J. Basic local alignment search tool. Journal of Molecular Biology, Amsterdam, v. 215, p. 403-410, 1990.

AMANN, R.I.; LUDWING, W. Ribosomal RNA-Targeted nucleic acid probes for studies in microbial ecology. Microbiology Reviews, New York, v. 24, p. 555-565, 2000.

AMANN, R.I.; LUDWIG, W.; SCHNEIDER, K.H. Phylogenetic identification and in situ detection of individual microbial cells without cultivation. Microbiological Reviews, New York, v. 59, p. 143-169, 1995.

ATLAS, R.M.; BARTHA, R. Microbial evolution and biodiversity: the origins of life. In:

ATLAS, R.M.; BARTHA, R. (Ed.). Microbial ecology: fundamentals and applications. $4^{\text {th }}$.ed. Menlo Park: Book News, 1997. p. 37-39.

BAENA, A.R.C.; FALESI, I.C. Avaliação do potencial químico e físico dos solos sob diversos sistemas de uso da terra em Santarém, Estado do Pará. Belém: Embrapa Amazônia Oriental, 2001. 32p. (Embrapa Amazônia Oriental. Boletim de Pesquisa, 33)

BARNS, S.M.; CAIN, E.C.; SOMMERVILLE, L.; KUSKE, C.R. Acidobacteria phylum sequences in uranium-contaminated subsurface sediments greatly expand the know diversity within the phylum. Applied and Environmental Microbiology, Baltimore, v. 73, n. 9, p. 3113 3116, 2007.

BIRNBOIM, H.C.; DOLY, J. A rapid alkaline extraction procedure for screening recombinant plasmid DNA. Nucleic Acids Research, Oxford, v. 7, p. 1513-1522, 1979.

BOHANNAN, B.J.M.; HUGHES, J. New approaches to analyzing microbial biodiversity data. Current Opinion in Microbiology, London, v. 6, p. 282-287, 2003.

BORNEMAN, J.; TRIPLETT, E.W. Molecular microbial diversity in soils from eastern amazonia: evidence for unusual microorganisms and microbial population shifts associated with deforestation. Applied Environmental Microbiology, Baltimore, v. 63, n.7, p. 2647-2653, 1997.

BORNEMAN, J.; SKROCH, P.W.; O'SULLIVAN, K.M.; PALUS, J.A.; RUMJANEK, N.G.; JANSEN, J.L.; NIENHUIS J.; TRIPLETT, E.W. Molecular microbial diversity of an agricultural soil in Wisconsin. Applied Environmental Microbiology, Baltimore, v. 62, n. 6, p. 1935-1945, 1996.

BRENT, E.; PHILL, G. Base-calling of automated sequencer traces using PHRED. II. Error probabilities processes by ${ }^{13} \mathrm{C}$-labelling of biomarkers. Nature, London, v. 392, p. 801-805, 1998.

CHAN, O.C.; YANG, X.; FU, Y.; FENG, Z.; SHA, L.; CASPER, P.; ZOU, X. 16SrRNA gene analyses of bacterial community structures in the soils of evergreen broad-leaved forests in southwest China. FEMS Microbiol Ecology, Amsterdam, v. 58, p. 247-259, 2006. 
CHAO, A.; SHEN, T.J.; HWANG, W. Application of laplace's boundary-mode approximations to estimate species and shared species richness. Australian \& New Zealand Journal of Statistics, Melbourne, v. 48, n. 2, p. 117-128, 2006.

COLE, J.R.; CHAI, B.; FARRIS, R.J.; WANG, Q.; KULAM, S.A.; McGARRELL, D.M.; GARRITY, G.M.; TIEDJE, J.M. The Ribosomal Database Project (RDP-II): sequences and tools for high-throughput rRNA analysis. Nucleic Acids Research, Oxford, v. 33, p. 294-296, 2005.

COURTOIS, S.; CAPPELLANO, C.M.; BALL, M.; FRANCOU, F.X.; NORMAND, P.; HELYNCK, G.; MARTINEZ, A.; KOLVEK, S.J.; HOPKE, J.; OSBURNE, M.S.; AUGUST, P.R.; GUERINEAU, M.; JEANNIN, P.; SIMONET, P.; PERNODET, J.L. Recombinant environmental libraries provide access to microbial diversity for drug discovery from natural products. Applied and Environmental Microbiology, Washington, v. 69, n. 1, p. 49-55, 2003.

COUTINHO, H.L.C.; OLIVEIRA, V.M. de; MANFIO, G.P.; ROSADO, A.S. Evaluating the microbial diversity of soil samples: methodologial innovation. Anais da Academia Brasileira de Ciências, Rio de Janeiro, v. 71, n. 3, p. 491-503, 1999.

CURY, J.C. Diversidade de Bacteria e Archaea em solos de mangue e marisma. 2006. 147 p. Tese (Doutorado em Solos e Nutrição de Plantas) - Escola Superior de Agricultura "Luiz de Queiroz”, Universidade de São Paulo, Piracicaba, 2006.

DUNBAR, J.; BARNS, S.M.; TICKNOR, L.O.; KUSKE, C.R. Empirical and theoretical bacterial diversity in four Arizona soils. Applied and Environmental Microbiology, Baltimore, v. 68 , n. 6 , p. 3035-3045, 2002.

ERICKSON, C. Historical ecology and future explorations. In: LEHMAM, J.; KERN, D.C.; GLASER, B.; WOODS, W.I. (Ed.). Amazonian dark earths: origin, properties \& management. Dordrecht: Kluwer Academic, 2003. p. 455-500.

EWING, B.; GREEN, P. Base-calling of automated sequencer traces using Phred. II errorprobabilities. Genome Research, Woodbury, v. 8, p. 186-194, 1998.

EWING, B.; HIJJIER, L.; WENDL, M.C.; GREEN, P. Base-calling of automated sequencer traces using Phred. I. Accuracy assessment. Genome Research, Woodbury, v. 8, p. 175-185, 1998.

FALCÃO, N.P.S.; BORGES, L.F. Efeito da fertilidade de terra preta de índio da Amazônia Central no estado nutricional e na produtividade do mamão hawaí (Carica papaya L.). Acta Amazônica, Manaus, v. 36, n. 3, p. 401-406, 2006.

FALESI, I.C. O estado atual dos conhecimentos sobre os solos da Amazônia brasileira. In: INSTITUTO DE PESQUISA AGROPECUÁRIA DO NORTE. Zoneamento agrícola da Amazônia: $1^{\mathrm{a}}$ aproximação. Belém, 1972. p. 17-67. (IPEAN. Boletim Técnico, 54). 
FELSKE, A.; WOLTERINK, A.; LIS, R.V.; AKKERMANS, A.D.L. Phylogeny of the main bacterial 16s rrna sequences in drentse a grassland soils (The Netherlands). Applied Environmental Microbiology, Baltimore, v. 64, n. 3, p. 871-879, 1998.

FARIAS, N.A.F.; OLIVEIRA, L.A. Uso de microorganismos solubilizadores de fosfatos em pupunheira num latossolo da região amazônica. In: SIMPÓSIO BRASILEIRO SOBRE MICROBIOLOGIA DO SOLO, 3., 1994, Londrina. Anais... 3. Simpósio Brasileiro sobre Microbiologia do solo e da 6. Reunião de laboratório para recomendação de stirpes de rizobio e bradrizobio, Londrina, 1994.

GARRITY, G.M.; BELL, J.A.; LILBURUN, T.G. Taxonomic outline of prokaryotes. In: Bergey's manual of systematic bacteriology. $2^{\text {nd }}$ ed. Release 5.0. New York: Springer, 2004. http://dx.doi.org/10.1007/bergeysoutline

GASTON, K.J. Species richness: measure and measurement. In: GASTON, K.J. (Ed.). Biodiversity: a biology of numbers and difference. Cambridge: Blackwell, 1996. p. 77-113.

GLASER, B.; GUGGENBERGER, G.; HAUMAIER, L.; ZECH, W. Persistence of soil organic matter in Archaeological soils (terra preta) of the Brazilian Amazon region. In: REES, R.M.; BALL, B.C.; CAMPBELL, C.D.; WATSON, C.A. (Ed.), Sustainable management of soil organic matter. Wallingford: CABI Publ., 2001. p. 190-194.

GOMEZ-ALVAREZ, V.; KING, G. M.; NUSSELEIN, K. Comparative bacterial diversity in recent Hawaiian volcanic deposits of different ages. FEMS Microbiology Ecology, Oxford, v. 60, p. 60-73, 2007.

GORDON, D.; ABAJIAN, C.; GREEN, P. Consed: a geographical tool for sequence finishing. Genome Research, Woodbury, v. 8, p. 195-202, 1998.

HACKL, E.; ZECHMEISTER-BOLTENSTERN, S.; BODROSSY, L.; SESSITSCH, A. Comparison of diversities and compositions of bacterial populations inhabiting natural forest soils. Applied and Environmental Microbiology, Baltimore, v. 70, n. 9, p. 5057-5065, 2004.

HANDELSMAN, J. Metagenomics: application of genomics to uncultured microorganisms. Microbiology and Molecular Biology Reviews, Washington, v. 68, n. 4, p. 669-685, 2004.

HEAD, I.M.; SAUNDERS, J.R.; PICKUP, J. Microbial evolution, diversity and ecology: a decade of ribosomal rRNA analysis of uncultivated organisms. Microbial Ecology, New York, v. 35, p. 121, 1998.

HERBERT, R. A. Methods for enumerating microorganisms and determining biomass in natural environments. In: NORRIS, J.R.; GRIGOROVA, R. (Ed.). Methods in microbiology: techniques in microbial ecology. San Diego: Academic Press, 1990. p. 1-40. 
HIRASHI, A.; KISHIMOTO, N.; KOSAKO, Y.; WAKAO, N.; TANO, T. Philogenetic position of the menaquinone-containing acidophilic chemoorganotroph Acidobacterium capsulatum. FEMS Microbiology Letters, Amsterdam, v. 132, p. 91-94, 1995.

http://www.personal.psu.edu/.../image002.png. Acesso em: 20 de agosto 2007.

HUNGENHOLTZ, P.; GOEBEL, B.M.; PACE, N.R. Impact of culture-independent studies on the emerging phylogenetic view of bacterial diversity. Journal of Bacteriology, Washington, v. 180, p. 4765-4774, 1998.

JOHNSON, M.J.; LEE, K.Y.; SCOW, K.M. DNA fingerprint reveals links among agricultural crops, soil properties, and the composition of soil microbial communities. Geoderma, Amsterdam, v. 114, n. 3/4, p. 279-303, 2003.

KERN, D.C. Caracterização de solos com Terra Preta Arqueológica na região de Oriximiná, Pará. 1988. 232 p. Dissertação (Mestrado em Agronomia) - Faculdade de Agronomia, Universidade Federal do Rio Grande do Sul, Porto Alegre, 1988.

KERN, D.C.; COSTA, M.L. Os solos antrópicos. In: LISBOA, P.L.B. (Org.). Caxiuanã. Belém: Museu Paraense Emílio Goeldi, 1997. p. 105-119.

KERN, D.C.; KÄMPF, N. Antigos assentamentos indígenas na formação de solos com Terra Preta Arqueológica na região de Oriximiná, Pará. Revista Brasileira de Ciência do Solo, Campinas, v. 13, p. 219-225, 1989.

KENNEDY, A.C. Bacterial diversity in agroecosystems. Agriculture, Ecosystems and Environment, Amsterdam, v. 74, p. 65-76, 1999.

KIM, J.S.; SPAROVEK, G.; LONGO, R.M.; De MELO, W.J.; CROWLEY, D. Bacteria diversity of terra preta and pristine forest soil from the western Amazon. Soil Biology and Biochemistry, Oxford, v. 39, p. 684-690, 2007.

KREBS, C.J. Ecological methodology. $2^{\text {nd }}$ ed. New York: Addilson Wesley Longman, 1998. 620 p.

KURTBOKE, D. I.; SWINGS, J.; STORMS, V. Microbial genetic resources and biodiscovery. United Kingdom, WFCC Publ., 2004. 400 p.

LAMBAIS, M.R.; CROWLEY, D.E.; CURY, J.; BULL, R.C. RODRIGUES, R.R. Bacterial diversity in tree canopies of the Atlantic forest. Science, Washington, v. 312, p. 1917, 2006.

LAMBAIS, M.R.; CURY, J.C.; MALUCHE-BARETTA, C.; BULL, R.C. Diversidade microbiana nos solos: definindo novos paradigmas. In: VIDAL-TORRADO, P.; ALLEONI, L.R.F.; COOPER, M.; SILVA, A.P.; CARDOSO, E.J. (Ed.). Tópicos em ciência do solo. Viçosa: Sociedade Brasileira de Ciência do Solo, 2005. v. 4, p. 43-84. 
LANE, D.J.; STAHL, D.A.; OLSEN, G.J.; HELLER, D.J.; PACE, N.R. Phylogenetic analysis of the genera Thiobacillus and Thiomicrospira by $5 \mathrm{~S}$ rRNA sequences. Journal of Bacteriology, Washington, v. 163, n. 1, p. 75-81, 1985.

LEHMANN, J.; SILVA, C. J.P. da; STEINER, C.; NEHLS, T.; ZECH, W.; GLASER, B. Nutrient availability and leaching in an archaeological Anthrosol and a Ferralsol of the Central Amazon basin: fertilizer, manure and charcoal amendments. Plant and Soil, Netherlands, v. 249, p. $343-$ $357,2002$.

LEWINSOHN, T.M.; PRADO, P.I. Estimativas de biodiversidade brasileira. In: LEWINSOHN, T.M.; PRADO, P.I.R. (Ed.). Biodiversidade brasileira: síntese do estado atual do conhecimento, São Paulo: Contexto, 2002. p. 91.

LIESACK, W.; STACKEBRANDT, E. Occurrence of novel groups of the domain Bacteria as revealed by analysis of genetic material isolated from Australian terrestrial environment. Journal of Bacteriology, Washington, v. 174, n. 15, p. 5072-5078, 1992.

LIESACK, W.; BAK, F.; KREFT, J.U.; STACKEBRANDT, E. Holophaga foetida gen. nov., sp. nov., a new homoacetogenic bacterium degrading methoxylated aromatic compounds. Archives of Microbiology, Germany, v. 162, n. 1/2, p. 85-90, 1994.

LIMA, H.N.; SHAEFER, C.E.R.; MELLO, J.W.V.; GILKES, R.J.; KER, J.C. Pedogenesis and pre-Colombian land use of "Terra Preta Anthrosolos" ("Indian black earth") of Westerns Amazonia. Geoderma, Netherlands, v. 110, p. 1-17, 2002.

LONERGAN, D.J.; JENTER, H.L.; COATES, J.D.; PHILLIPS, E.J.; SCHMIDT, T.M.; LOVLEY, D.R. Phylogenetic analysis of dissimilatory Fe (III)-reducing bacteria. Journal of Bacteriology, Washington, v. 178, n. 8, p. 2402-2408, 1996.

MACNEIL, I.A.; TIONG, C.L.; MINOR, C.; AUGUST, P.R.; GROSSMAN, T.H.; LOIACONO, K.A.; LYNCH, B.A.; PHILLIPS, T.; NARULA, S.; SUNDARAMOORTHI, R.; TYLER, A.; ALDREDGE, T.; LONG, H.; GILMAN, M.; HOLT, D.; OSBURNE, M.S. Expression and isolation of antimicrobial small molecules from soil DNA libraries. Journal of Molecular Microbiology and Biotechnology, Switzerland, v. 3, p. 301-308, 2001.

MADARI, B.; BENITES, V.M.; CUNHA, T.J.F. The effect of management on the fertility of Amazonian anthropogenic dark earth soils: a review. In: INTERNATIONAL WORKSHOP ON TERRA PRETA SOILS, 1., 2002, Manaus. Abstracts ... Manaus, 2002. p. 29.

McCAIG, A.E.; GLOVER, L.A.; PROSSER, J.I. Molecular analysis of bacterial community structure and diversity in unimproved and improved upland grass pastures. Applied and Environmental Microbiology, Washington, v. 65, n. 4, p. 1721-1730, 1999.

MITSUI, H.; GORLACH, K.; LEE, H.J.; HATTORI, R.; HATTORI, T. Incubation time and media requirements of culturable bacteria from different phylogenetic groups. Journal of Microbiological Methods, Netherlands, v. 30, n. 2, p. 103-110, 1997. 
MOREIRA, F.M.S.; SIQUEIRA, J.O. Microbiologia e bioquímica do solo. Lavras: UFLA, 2002. $626 \mathrm{p}$.

NUBEL, U.; GARCIA-PICHEL, F.; KUHL, M.; MUYZER, G.Quantifying microbial diversity: morphotypes, 16S rRNA genes, and carotenoids of oxygenic phototrophs in microbial mats. Applied and Environmental Microbiology, Baltimore, v. 65, p. 422-443, 1999.

NUNES, G.L. Diversidade e estrutura de comunidades de Bacteria e Archaea em solo de mangue contaminado com hidrocarbonetos do petróleo. 2006. 84 p. Dissertação (Mestrado em Microbiologia Agrícola) - Escola Superior de Agricultura "Luiz de Queiroz", Universidade de São Paulo, Piracicaba, 2006.

NÜSSLEIN, K.; TIEDJE, J.M. Soil bacterial community shift correlated with change from forest to pasture vegetation in a tropical soil. Applied and Environmental Microbiology, Baltimore, v. 65, n. 8, p. 3622-3626, 1999.

O'NEILL, B.; GROSSMAN, J.; TSAI, S.M.; GOMES, J.E.; GARCIA, C.E.; SOLOMON, D.; LIANG, B.; LEHMANN, J.; THIES, J. isolating unique bacteria from terra preta systems: using culturing and molecular tools for characterizing microbial life in terra preta. In: WORLD CONGRESS OF SOIL SCIENCE IN PHILADELPHIA, 2006, Philadelphia. Philadelphia: Word Union of Soil Sciences, 2006, p. 105.

PAABO, S.; IRWIN, D.M.; WILSON, A.C. DNA damage promotes jumping between templates during enzymatic amplification. Journal of Biological Chemistry, Baltimore, v. 265, p. 4718 4721, 1992.

PACE, N.R. A molecular view of microbial diversity and the biosphere. Science, Washington, v. 276, p. 734-740, 1997.

RANJARD, L.; POLY, F.; NAZARET, S. Monitoring complex bacterial communities using culture-independent molecular techniques: application to soil environment. Research in Microbiology, France, v. 51, n. 3, p. 167-177, 2000.

REIS JR., F.B.; MENDES, I.C.; TEIXEIRA, K.R.S.; REIS, V.M. Uso de ferramentas moleculares em estudos da diversidade de microrganismos do solo. Brasília: Embrapa Cerrados, 2003. 26 p. (Embrapa Cerrados. Documentos, 51).

RONDON, M.R.; GOODMAN, R.M.; HANDELSMAN, J. The Earth's bounty: assessing and accessing soil microbial diversity. Trends in Biotechnology, Amsterdam, v. 17, p. 403-409, 1999.

ROSSELÓ-MORA, R.; AMANN, R. The species concept for prokaryotes. FEMS Microbiology Review, Amsterdam, v. 25, n. 1, p. 39-67, 2001.

SAIKI, R.K.; SCARF, F.; FALOONA, F.A.; MULLIS, K.B.; HORN, G.T.; ERLICH, H.A.; ARNHEIM, N. Enzymatic amplification of B-globin genomic sequences and restriction site analysis for diagnosis of sickle cell anemia. Science, Washington DC, v. 230, p. 1350-1354, 1985. 
SAMBROOK, J.; FRITSCH, E.F.; MANIATIS, T. Molecular cloning: a laboratory manual. $2^{\text {nd }} \mathrm{ed}$. Cold Harbor: Cold Spring Harbor Laboratory Press, 1989. 999 p.

SANDAA, R.A.; TORSVIK V.; ENGER O. Influence of long-term heavy-metal contamination on microbial communities in soil. Soil Biology \& Biochemistry, Oxford, v. 33, n. 3, p. 287-295, 2001.

SCHLOSS, P.D.; HANDELSMAN, J. Introducing to DOTUR, a computer program for defining operacional taxonomic units and estimating species richness. Applied and Environmental Microbiology, Baltimore, v. 71, p. 1501-1506, 2005.

SILVEIRA, I.M.; KERN, D.C.; QUARESMA, H.D.A.B. Reconstruindo uma ocupação. In: LISBOA, P.L.B. Caxiuanã populações tradicionais, meio físico e diversidade biológica. Belém: Museu Paraense Emílio Goeldi, 2002. p. 59-76.

SHANNON, C.E.; WEANER, W. The mathematical theory of communication. Urbana: University Illinois Press, 1949. 117 p.

SHEN, T.J.; CHAO, A.; LIN, C.F. Predicting the number of new species in further taxonomic sampling. Ecology, Ithaca, v. 84, n. 3, p. 798-804, 2003.

SIMPSON, E. H. Measurement of diversity. Nature, London, v. 163, p. 688, 1949.

SOMBROEK, W.; RUIVO, M.L.; FEARNSIDE, P.M.; GLASER, B.; LEHMANN, J. Amazonian dark earths as carbon stores and sinks. In: LEHMAM, J.; KERN, D.C.; GLASER, B.; WOODS, W.I. (Ed.). Amazonian dark earths: origin, properties \& management. Dordrecht: Kluwer Academic Publ., 2003. p. 125-139.

SOMBROEK, W. G. Amazon soils: A Reconnaissance of the Soils of the Brazilian Amazon Region. Wageningen, Center for Agricultural Publications and Documentation. 1966. 292 p.

SMITH, N. J. H. Anthrosols and human carrying capacity in Amazonia. Annals of the Association of American Geographers, v. 70, p. 553-566, 1980.

STACH, J. E. M.; MALDONADO, L. A.; MASSON, D. G.; WARD, A. C.; GOODFELLOW, M.; BULL, A. T. Statistical approaches for estimating actinobacterial diversity in marine sediments. Applied and Environmental Microbiology, Washington, p. 6189-6200, 2003.

THIES, J.; SUZUKI, K. Amazonian dark earths biological measurements. In: LEHMAM, J.; KERN, D.C.; GLASER, B.; WOODS, W.I. (Ed.). Amazonian dark earths: origin, properties \& management. Dordrecht: Kluwer Academic, 2003. p. 1-45.

THOMPSON, J.D.; GIBSON, T.J.; PLEWNIAK, F.; JEANMOUGIN, F.; HIGGINS, D.G. The CLUSTAL_X windows interface: flexible strategies for multiple sequence alignment aided by quality analysis tools. Nucleic Acids Research, Oxford, v. 25, p. 4876-4882, 1997. 
TIEDJE, J.M.; CHO, J.C.; MURRAY, A.; TREVES, D.; XIA, B.; AHOU, J. Soil teeming with life: new frontiers for soil science. In: REES, R.M.; BALL, B.C.; CAMPEBELL, C.D.; WATSON, C.A. (Org.). Sustainable management of soil organic matter. Wallingford: CAB International, 2001. p. 393-412.

TORSVIK, V.; GOKSOYR, J.; DAEE, F. L. High diversity in DNA of soil bacteria. Applied and Environmental Microbiology, Washington, DC, v.56, p. 782-787, 1990.

TSAI, S.M.; CANNAVAN, F.S.; SILVA Jr., J.P.; CHAVES, M.G.; PASSIANOTO, C.C.; BORGES, C.P. Diversidade bacteriana em terra preta de índio baseada em seqüenciamento do gene 16S rRNA. In: CONGRESSO BRASILEIRO DE CIÊNCIA DO SOLO, 29; 2003, Ribeirão Preto. Resumos ... Ribeirão Preto: SBCS, 2003. 1 CD-ROM.

VIEIRA, L.S.; SANTOS, P.C.T.C. Amazônia: seus solos e outros recursos naturais. São Paulo: Agronômica Ceres, 1987. 416 p.

WANG, G.C.Y.; WANG, Y. Frequency of formation of chimeric molecules as a consequence of PCR co-amplification of 16S rRNA genes from different bacterial species. Applied and Environmental Microbiology, Baltimore, v. 63, n. 12, p. 4645-4650, 1997.

WEISBURG, W.G.; BARNS, S.M.; PELLETIER, D.A.; LANE, D.J. 16S ribosomal DNA amplification for phylogenetic study. Journal of Bacteriology, Washington, v. 173, p. 697-703, 1991.

WHITMAN, W.B.; COLEMAN, D.C; WIEBE, W.J. Prokaryotes: the unseen majority. Proceedings of the National Academy of Sciences of the USA, Washington, v. 95, p. 65786583, 1998.

WOESE, C.R. Bacterial evolution. Microbiology Reviews, New York, v. 51, n. 2, p. 221-271, 1987.

WOODSON, S.A.; LEONTIS, N.B. Structure and dynamics of ribosomal RNA. Current Opinion in Structural Biology, London, v. 8, n. 3, p. 294-300, 1998. 
ANEXOS 
Anexo A - Resultados das comparações das seqüências parciais da região 16S rRNA obtidas em amostras de solo Terra Preta Antropogênica e respectivos solos adjacentes da região

\begin{tabular}{|c|c|c|c|c|}
\hline Filotipo/Clone & ID \% & No. acesso & pb & evalue \\
\hline 01-BITPA1A07 & 93 & EF073454 & 554 & $3 e-144$ \\
\hline 02-BITPA1H05 & 98 & DQ129235 & 439 & 0.0 \\
\hline 03-BITPA2B02 & 95 & EF075739 & 541 & 0.0 \\
\hline 04-BITPA3D 10 & 98 & EF516749 & 592 & 0.0 \\
\hline 05-BITPA2E01 & 98 & EF516715 & 602 & 0.0 \\
\hline 06-BITPA1A01 & 98 & EF516825 & 534 & 0.0 \\
\hline 07-BITPA2D03 & 91 & AY 963331 & 478 & 0.0 \\
\hline 08-BITPA3C06 & 97 & EF018507 & 554 & 0.0 \\
\hline 09-BITPA1F09 & 98 & DQ128664 & 451 & 0.0 \\
\hline 10-BITPA $1 \mathrm{C} 12$ & 90 & EF073768 & 479 & 0.0 \\
\hline 11-BITPA1E07 & 95 & AY694648 & 624 & 0.0 \\
\hline 12-BITPA1E02 & 98 & AY326536 & 552 & 0.0 \\
\hline 13-BITPA3F09 & 98 & EF073039 & 543 & 0.0 \\
\hline 14-BITPA3D05 & 98 & AY326533 & 520 & 0.0 \\
\hline 15-BITPA3E02 & 97 & DQ129139 & 498 & 0.0 \\
\hline 16-BITPA3H08 & 98 & EF455194 & 639 & 0.0 \\
\hline 17-BITPA3H 11 & 97 & AY963438 & 645 & 0.0 \\
\hline 18-BITPA3A08 & 98 & EF073011 & 642 & 0.0 \\
\hline 19-BITPA3E06 & 96 & DQ664148 & 582 & 0.0 \\
\hline 20-BITPA3H05 & 97 & DQ664148 & 512 & 0.0 \\
\hline 21-BITPA3D03 & 97 & DQ664148 & 508 & 0.0 \\
\hline 22-BITPA1F02 & 98 & EF457377 & 474 & 0.0 \\
\hline 23-BITPA3E01 & 99 & AY694576 & 460 & 0.0 \\
\hline 24-BITPA3A04 & 93 & EF457307 & 555 & 0.0 \\
\hline 25-ВITPA3C 08 & 93 & $\mathrm{AB} 254785$ & 534 & 0.0 \\
\hline 26-BITPA3G02 & 94 & AB254785 & 557 & 0.0 \\
\hline 27-BITPA $1 \mathrm{C} 10$ & 98 & EF073347 & 425 & 0.0 \\
\hline 28-BITPA3C07 & 97 & EF072701 & 574 & 0.0 \\
\hline 29-BITPA1B07 & 98 & EF455380 & 510 & 0.0 \\
\hline 30-BITPA2A07 & 95 & СР000284 & 459 & 0.0 \\
\hline 31-ВITPA3В06 & 94 & EF019260 & 586 & 0.0 \\
\hline 32-BITPA3G01 & 96 & AB252910 & 663 & 0.0 \\
\hline 33-BITPA1E04 & 94 & EF590055 & 583 & 0.0 \\
\hline 34-BITPA2B04 & 96 & AY989412 & 552 & 0.0 \\
\hline 35-BITPA3D04 & 98 & AB240235 & 606 & 0.0 \\
\hline 36-BITPA3G11 & 99 & AM696997 & 537 & 0.0 \\
\hline 37-BITPA2G02 & 97 & EF018459 & 582 & 0.0 \\
\hline 38-BITPA2A09 & 99 & DQ643756 & 505 & 0.0 \\
\hline 39-BITPA2G01 & 97 & DQ129016 & 478 & 0.0 \\
\hline 40-BITPA1F04 & 97 & EF075811 & 467 & 0.0 \\
\hline 41-BITPA1E01 & 99 & DQ128941 & 473 & 0.0 \\
\hline 42-BITPA 1 A08 & 99 & AY326628 & 632 & 0.0 \\
\hline 43-BITPA1A09 & 97 & AB089250 & 468 & 0.0 \\
\hline 44-BITPA1G07 & 94 & AB249949 & 416 & $2 \mathrm{e}-179$ \\
\hline 45-BITPA1D04 & 97 & AB245375 & 509 & 0.0 \\
\hline 46-BITPA1B01 & 99 & AB190067 & 468 & 0.0 \\
\hline
\end{tabular}

\section{Organismo}

Uncultured Firmicutes bacterium clone GASP-WB1S3_G08 Uncultured soil bacterium clone CWT ST03_H03G Uncultured Firmicutes bacterium clone GASP-WDOW1 E02 Uncultured bacterium clone FCPS394 Uncultured bacterium clone FCPT492 Uncultured bacterium clone FCPN424 Uncultured bacterium clone AH38

Uncultured bacterium clone Amb_16S_1143 Uncultured soil bacterium clone HSB NT21_H02

Uncultured Acidobacteria bacterium clone JAB SMS 53 Uncultured soil bacterium clone 1091-1

Uncultured Firmicutes bacterium clone GASP-WA2W3_G07 Uncultured soil bacterium clone 1267-1

Uncultured soil bacterium clone CWT ST01 C03

Uncultured soil bacterium clone $\mathrm{C} 53-\mathrm{Fw}$ Uncultured bacterium clone AS78

Uncultured Acidobacteria bacterium clone GASP-WA2W3 E01 Uncultured bacterium clone 9S56 Uncultured bacterium clone 9 S56 Uncultured bacterium clone 9S56

Uncultured Acidobacteria bacterium clone BGA.0006 Uncultured Acidobacteria bacterium clone JAB SMS 16

Uncultured Acidobacteria bacterium clone T10.0031

Uncultured bacterium clone: TakashiA-B36 Uncultured bacterium clone: TakashiA-B36

Uncultured Firmicutes bacterium clone GASP-WB1S1_F01

Uncultured Firmicutes bacterium clone GASP-WA2S3 304 Uncultured soil bacterium clone E54-Fw

Methylobacillus flagellatus $\mathrm{KT}$, complete genome

Uncultured Nitrosomonadaceae bacterium clone Elev_16S_442 Uncultured beta proteobacterium clone: 015 Uncultured bacterium clone A2

Uncultured soil bacterium clone L1A2E06 Uncultured bacterium clone: BS038

Uncultured Phyllobacteriaceae bacterium clone Amb_16S_1085 Uncultured soil bacterium clone W4Ba96

Uncultured soil bacterium clone HSB OF53_D09RU

Uncultured Rhodoplanes sp. clone GASP-WDOW2_F11

Uncultured soil bacterium clone HSB OF23 H08 Uncultured soil bacterium clone 307Paenibacillus sp. M-2b

(0092 Bacillales bacterium Gsoil 1105 Bacillus sp. N-31-25-5

\section{Ambiente - Autor}

Diversidade bacteriana em solos de pastagem e agricultura- Piedmont EUA-Jangid,K. et al., 2006 Diversidade bacteriana em solos de pastagem e agricultura- Piedmont EUA - Jangid,K. et al,2006 Diversidade bacteriana em solos de pastagem e agricultura- Piedmont EUA - Jangid,K. et al.,2006

Comunidade microbiana solo - Califórnia-Cruz,K. et al., 2007

Comunidade microbiana solo - California-Cruz,K. et al., 2007

Comunidade microbiana solo - California-Cruz,K. et al., 2007

Comunidades bacterianas em solos de floresta (China)-Chan,O.C. et al., 2006

Diversidade bacteriana solo - Aspen -Lesaulnier,C.C. et al., 2007

Diversidade bacteriana em solos de pastagem e agricultura- Piedmont EUA - Jangid,K. et al.,2006

Comunidades bacterianas em solos-Val-Moraes,S.P. et al., 2005 Terra Preta - Amazônia - Kim,J.-S. et al., 2006

Diversidade bacteriana co solos de pastagem e agricultura- Piedmont EUA - Jangid,K. et al.,2006 Terra Preta - Amazônia - Kim,J.-S. et al., 2006

Comunidades bacterianas em solos de floresta-Upchurch,R. et al., 2006

Diversidade bacteriana - solo contaminado Hg (EUA)-Oregaard,G. et al., 2007

Comunidades bacterianas em solos de floresta (China)-Chan,O.C. et al., 2006

Diversidade bacteriana em solos de pastagem e agricultura- Piedmont EUA - Jangid,K. et al.,2006 Comunidades microbianas-sedimentos contaminados petróleo-Allen,J.P. et al., 2007 Comunidades microbianas-sedimentos contaminados petróleo-Allen,J.P. et al., 2007 Comunidades microbianas-sedimentos contaminados petróleo-Allen,J.P. et al., 2007

Sedimentos subsuperficiais contaminados urânio-Barns,S.M. et al., 2007

Comunidades bacterianas em solos-Val-Moraes,S.P. et al., 2005

Sedimentos subsuperficiais contaminados urânio-Barns,S.M. et al., 2007

Comunidade bacteriana em sedimentos redutores-Yoshida,H. et al., 2007

Diversidade bacteriana em solos de pastagem e agricultura- Piedmont EUA - Jangid,K. et al.,2006

Diversidade bacteriana em solos de pastagem e agricultura- Piedmont EUA - Jangid K . et. 2, 2006

Diversidade bacteriana - solo contaminado Hg (EUA)-Oregaard,G. et al., 2007

Complete sequence of Methylobacillus flagellatus KT-Copeland,A. et al., 2006

Diversidade bacteriana solo - Aspen -Lesaulnier,C.C. et al., 2007 Identificação bacteriana Japão - Sakurai,K. et al., 2006

Diversidade bacterian em sedimentos contaminados com nitrobenzeno - Li,D. et al., 2007 Bacteria de solo-Schloss,P.D. and Handelsman,J., 2005

Diversidade bacteriana de rizosfera - Nakamura,Y. et al., 2005 Diversidade bacteriana - Rintala,H. et al., 2007

Diversidade bacteriana solo - Aspen -Lesaulnier,C.C. et al., 2007 Diversidade microbiana de solo - Lueders,T. et al., 2006

Comunidades bacterianas em solos de floresta-Upchurch,R. et al., 2006

Diversidade bacteriana em solos de pastagem e agricultura- Piedmont EUA - Jangid,K. et al.,2006

Comunidades bacterianas em solos de floresta-Upchurch,R. et al., 2006 Terra Preta - Amazônia - Kim,J.-S. et al., 2006 Rizosfera de espinafre - Hosoda,A. et al., 2004

Análise filogenética de Streptomices-Tamura,T. et al., 2006

Diversidade bacteriana de solos - Im,W. and Lee,S., 2006

Comunidade microbiana de solo - Takaku,H. et al., 2007 
Anexo A - Resultados das comparações das seqüências parciais da região 16S rRNA obtidas em amostras de solo Terra Preta Antropogênica e respectivos solos adjacentes da região Amazônica, com as amostras depositadas no GeneBank utilizando o programa Blast

(continuação)

\begin{tabular}{|c|c|c|c|c|}
\hline Filotipo/Clone & ID \% & No. acesso & pb & evalue \\
\hline 47-BITPA1C07 & 98 & AY930449 & 426 & 0.0 \\
\hline 48-BITPA2D09 & 99 & AY326628 & 400 & 0.0 \\
\hline 49-ВITPA3А10 & 97 & AY607169 & 579 & 0.0 \\
\hline 50-BITPA3F11 & 98 & AY389851 & 601 & 0.0 \\
\hline 51-BITPA3D08 & 97 & AY360596 & 624 & 0.0 \\
\hline 52-BITPA3A05 & 99 & DQ275176 & 608 & 0.0 \\
\hline 53-BITPA1C04 & 97 & AY360639 & 604 & 0.0 \\
\hline 54-BITPA1H08 & 97 & DQ839176 & 539 & 0.0 \\
\hline 55-BITPA1C09 & 98 & DQ248043 & 532 & 0.0 \\
\hline 56-ВITPA3А07 & 98 & DQ248043 & 588 & 0.0 \\
\hline 57-BITPA1G10 & 99 & EF178451 & 486 & 0.0 \\
\hline 58-BITPA3C12 & 95 & AM159318 & 663 & 0.0 \\
\hline 59-BITPA3A11 & 97 & EF455181 & 576 & 0.0 \\
\hline 60-BITPA3B10 & 99 & AB271135 & 502 & 0.0 \\
\hline 61-BITPA2B03 & 98 & DQ288678 & 495 & 0.0 \\
\hline 62-BITPA1D08 & 96 & AM162306 & 626 & 0.0 \\
\hline 63-BITPA1G02 & 97 & AY326632 & 534 & 0.0 \\
\hline 64-BITPA3C04 & 99 & AJ251193 & 541 & 0.0 \\
\hline 65-BITPA1D10 & 93 & DQ830599 & 605 & 0.0 \\
\hline 66-BITPA2A03 & 88 & EF074330 & 519 & $3 e-178$ \\
\hline 67-BITPA1A04 & 98 & AY963450 & 469 & $3 e-153$ \\
\hline 68-BITPA1F05 & 87 & AJ229195 & 542 & $4 e-177$ \\
\hline 69-BITPA2C02 & 95 & DQ129042 & 520 & 0.0 \\
\hline 70-BITPA3G10 & 98 & AY177762 & 392 & 0.0 \\
\hline 71-BITPA2C03 & 88 & AF432698 & 432 & $5 e-142$ \\
\hline 72-BITPA1A03 & 93 & AY242744 & 581 & 0.0 \\
\hline 73-BITPA1E12 & 98 & EF455149 & 483 & 0.0 \\
\hline 74-BITPA1C05 & 91 & EF019330 & 556 & 0.0 \\
\hline 75-BITPA1B03 & 98 & DQ451477 & 437 & 0.0 \\
\hline 76-BITPA2C01 & 91 & X83407 & 447 & $2 e-170$ \\
\hline 77-BITPA1B05 & 97 & EF018668 & 506 & 0.0 \\
\hline 78-BITPA2G03 & 96 & EF516723 & 433 & 0.0 \\
\hline 79-ВITPА3В03 & 96 & AY326539 & 553 & 0.0 \\
\hline 80-BITPA3G12 & 96 & DQ451443 & 529 & 0.0 \\
\hline 81-BITPA3E04 & 96 & EF018530 & 547 & 0.0 \\
\hline 82-BITPA3F05 & 98 & EF073942 & 600 & 0.0 \\
\hline 83-ВITPA3Н01 & 97 & EF516553 & 680 & 0.0 \\
\hline 84-BITPA3D12 & 96 & EF072588 & 669 & 0.0 \\
\hline 85-BITPA3F06 & 96 & EF073584 & 566 & 0.0 \\
\hline 86-BITPA3G09 & 98 & DQ128789 & 545 & 0.0 \\
\hline 87-BITPA1E05 & 85 & AY221042 & 503 & $5 e-147$ \\
\hline 88-BITPA3F08 & 92 & DQ129135 & 460 & 0.0 \\
\hline 89-BITPA1G01 & 93 & DQ083296 & 374 & $4 e-158$ \\
\hline 90-BITPA2Е03 & 94 & DQ830033 & 504 & 0.0 \\
\hline 91-ВITPA3В01 & 92 & DQ830033 & 500 & 0.0 \\
\hline 92-BITPA2B11 & 94 & EF075298 & 447 & 0.0 \\
\hline 93-ВITPA3Н03 & 97 & AB240310 & 555 & 0.0 \\
\hline 94-BITPA2A02 & 96 & DQ830224 & 510 & 0.0 \\
\hline
\end{tabular}

Organismo

Ambiente - Autor

Uncultured bacterium clone OC19
Uncultured soil bacterium clone $307-1$

Uncultured Bacilli bacterium clone X9Ba25

Uncultured bacterium clone NBFF469

Uncultured Bacilli bacterium clone $\mathrm{M} 10 \mathrm{~B}$ 04

Bacillus drentensis strain WN575

Uncultured Bacilli bacterium clone M10Ba51

Uncultured Bacillus sp. clone LOTc

Bacillus sp. L105

Bacillus sp. L105

Uncultured Bacillaceae bacterium, clone LrhB07

Uncultured soil bacterium clone $\mathrm{C} 40-\mathrm{Fw}$

Bacillus funiculus strain: MX12-2

Bacillus sp. GPTSA 27T

Paenibacillus sp. 4GH18-10

Uncultured soil bacterium clone 43-1

Paenibacillus sp. TRO4 isolate TRO4 (=LMG19081)

Uncultured bacterium clone PAS3_A11

Uncultured Bacillus sp. clone GASP-WB2W3_F04 Uncultured bacterium clone BS12

Unidentified eubacterium from anoxic bulk soil (clone BSV39)

Uncultured soil bacterium clone CWT SM01_C05

Uncultured bacterium clone SMS9.97WL

Uncultured soil bacterium clone Tc119-C02

Uncultured soil bacterium clone C08-Fw

Uncultured proteobacterium clone Elev_16S_539

Uncultured Nitrospirae bacterium clone FAC 38 AIRNA16S A.ilicis

Uncultured bacterium clone Amb_16S_955 Uncultured bacterium clone FCPP5 15 Uncultured soil bacterium clone 869-1

Uncultured Acidobacteria bacterium clone FAC4

Uncultured Acidobacteria bacterium clone Amb 16S_790

Uncultured Acidobacteria bacterium clone GASP-W̄B $2 \overline{\mathrm{S}} 2$ C02 Uncultured bacterium clone FCPP631

Uncultured proteobacterium clone GASP-WA2S1_F03

Uncultured Acidobacteria bacterium clone GASP-WB siW
Uncultured soil bacterium clone HSB NT53 B09 Uncultured bacterium clone CCM11b
(b)

Uncultured bacterium clone CCM11b
Uned soil bacterium clone CWT ST01_B02

Uncultured bacterium clone EC1091
Und

Uncultured bacterium clone EC1091
Uncultured bacterium clone CON1_F09

Uncultured bacterium clone CON1_F09

Uncultured proteobacterium clone GASP-WC2W2_F12 Uncultured bacterium clone: RB127

Uncultured bacterium clone CON3_G09
Comunidade bacteriana - solo arroz-Ka,J.-O. et al., 2006

Terra Preta - Amazônia - Kim,J.-S. et al., 2006

Diversidade microbiana de solo - Lueders T. et al 2004

Amostras ambientais do Parque Nacional de Yellowstone-Botero,L.M. and McDermott,T.R.,2005 Diversidade microbiana de solo - Lueders,T. et al., 2004

Bacillus Endospores isolado do granito-Fajardo-Cavazos,P. and Nicholson,W., 2006

Diversidade microbiana de solo - Lueders,T. et al., 2004

Diversidade bacteriana de solo - Fru,E.C. et al., 2007

Diversidade bacteriana - Kartchner Caverns, Arizona-Ikner,L.A. et al., 2007

Diversidade bacteriana - Kartchner Caverns, Arizona-Ikner,L.A. et al., 2007 Solo - Yang,J.H. and Guo,J.H., 2007

Comunidade bacteriana de solo de arroz - Lu,Y. et al., 2006

Diversidade bacteriana - solo contaminado Hg (EUA)-Oregaard,G. et al., 2007

Identificação bacteriana de solos - Kinegam,S. et al., 2006 Solo - Saha,P. and Chakrabarti,T., 2005

Solos Coreia - Weon,H.-Y. and Kwon,S.-W., 2005

erra Preta - Amazônia - Kim,J.-S. et al., 2006 Isolados de plantas e solos-Berge,O. et al, 2002

Comunidades bacterianas em solos de floresta-Upchurch,R. et al., 2006

Diversidade bacteriana em solos de pastagem e agricultura- Piedmont EUA - Jangid,K. et al.,2006

Comunidades bacterianas em solos de floresta (China)-Chan,O.C. et al., 2006

Diversidade bacteriana de solo de cultura de arroz-Hengstmann,U. et al., 1999

Comunidades bacterianas em solos de floresta-Upchurch,R. et al., 2006

Diversidade bacteriana solos Califórnia-LaMontagne,M.G. et al., 2003

Diversidade bacteriana solos de floresta da Colômbia-Axelrood,P.E. et al., 2004 Solo contaminado com metal pesado-Gremion,F. et al., 2003

Diversidade bacteriana - solo contaminado Hg (EUA)-Oregaard,G. et al., 2007

Diversidade bacteriana solo - Aspen-Lesaulnier,C.C. et al., 2007

Comunidade bacteriana solo de Taiwan-Tsai,S.-H. et al, 2006 Isolado de Arthrobacter -Koch,C. et al., 1995

Diversidade bacteriana solo - Aspen -Lesaulnier,C.C. et al., 2007

Comunidade microbiana solo da Califórnia-Cruz,K. et al.,2007 Terra Preta - Amazônia - Kim J.S. et al, 2006

Comunidade bacteriana solo de Taiwan-Tsai,S.H. et al., 2006

Diversidade bacteriana solo - Aspen - Lesaulnier,C.C. et al., 2007

Diversidade bacteriana em solos de pastagem e agricultura- Piedmont EUA - Jangid,K. et al.,2006

Comunidade microbiana solo da Califórnia-Cruz,K. et al.,2007

Diversidade boction al.,2006 Diversidade bacteriana em solos de pastagem e agricultura- Piedmont EUA - Jangid,K. et al.,2006

Comunidades bacterianas em solos de floresta-Upchurch,R. et al., 2006 Bactérias da caverna Mammoth - Fowler,R. et al., 2003

Comunidades bacterianas em solos de floresta-Upchurch,R. et al., 2006 Acidobacteria - Sait,M. et al., 2006

Comunidades bacterianas em solos arroz-Upchurch,R. et al., 2006

Comunidades bacterianas em solos arroz-Upchurch,R. et al., 2006

Diversidade bacteriana em solos de pastagem e agricultura- Piedmont EUA - Jangid,K. et al.,2006

Diversidade bacteriana de rizosfera - Nakamura,Y. et al., 2005

Comunidades bacterianas em solos arroz-Upchurch,R. et al., 2006 
Anexo A - Resultados das comparações das seqüências parciais da região 16S rRNA obtidas em amostras de solo Terra Preta Antropogênica e respectivos solos adjacentes da região Amazônica, com as amostras depositadas no GeneBank utilizando o programa Blast

(continuação)

\begin{tabular}{|c|c|c|c|}
\hline Filotipo/Clone & ID \% & No. acesso & pb \\
\hline 95-BITPA3A01 & 98 & EF515913 & 613 \\
\hline 96-ВITPA3B04 & 96 & EF457455 & 503 \\
\hline 97-ВITPA3H09 & 95 & EF018729 & 511 \\
\hline 98-BITPA1B09 & 94 & DQ830283 & 520 \\
\hline 99-BITPA2E04 & 98 & DQ129007 & 459 \\
\hline 100-BITPA2B10 & 96 & EF494348 & 463 \\
\hline 101-BITPA3H02 & 95 & EF516621 & 637 \\
\hline 102-BITPA2E10 & 98 & DQ129134 & 523 \\
\hline 103-BITPA2D02 & 97 & EF516880 & 622 \\
\hline 104-BITPA3D02 & 96 & EF075407 & 662 \\
\hline 105-BITPA1F07 & 97 & DQ395983 & 494 \\
\hline 106-BITPA3B05 & 95 & EF494340 & 512 \\
\hline 107-BITPA1D05 & 93 & DQ827992 & 508 \\
\hline 108-BITPA2A06 & 96 & DQ110126 & 464 \\
\hline 109-BITPA1A12 & 98 & EF072768 & 380 \\
\hline 110-BITPA1E09 & 85 & AY 150890 & 499 \\
\hline 111-BITPA3G08 & 92 & EF516213 & 485 \\
\hline 112-BITPA2A04 & 96 & DQ026645 & 562 \\
\hline 113-BITPA2A05 & 95 & EF075355 & 515 \\
\hline 114-BITPA3C03 & 97 & AY724093 & 584 \\
\hline 115-BITPA2B01 & 98 & AY921859 & 520 \\
\hline 116-BITPA3A06 & 94 & AY 177765 & 621 \\
\hline 117-BITPA2A12 & 94 & EF516169 & 615 \\
\hline 118-BITPA2F02 & 95 & EF019526 & 678 \\
\hline 119-BITPA3G03 & 96 & DQ128963 & 474 \\
\hline 01-BIADJ1A03 & 97 & EF073403 & 587 \\
\hline 02-BIADJ2A08 & 98 & EF516517 & 615 \\
\hline 03-BIADJ1H02 & 98 & EF018422 & 663 \\
\hline 04-BIADJ2H10 & 99 & AY326601 & 589 \\
\hline 05-BIADJ1G04 & 97 & AB240329 & 591 \\
\hline 06-BIADJ1B01 & 97 & AY326607 & 592 \\
\hline 07-BIADJ1H01 & 96 & EF018562 & 695 \\
\hline 08-BIADJ3C04 & 99 & DQ453803 & 607 \\
\hline 09-BIADJ2H07 & 98 & AY775511 & 588 \\
\hline 10-BIADJ3G09 & 98 & DQ830370 & 465 \\
\hline 11-BIADJ3A10 & 95 & EF073443 & 460 \\
\hline 12-BIADJ1A08 & 92 & DQ884916 & 554 \\
\hline 13-BIADJ1C10 & 96 & EF073929 & 573 \\
\hline 14-BIADJ1D01 & 92 & DQ129058 & 548 \\
\hline 15-BIADJ1G05 & 92 & AY043794 & 517 \\
\hline 16-BIADJ1A09 & 91 & EF018306 & 522 \\
\hline 17-BIADJ2F10 & 99 & AY387367 & 535 \\
\hline 18-BIADJ1G10 & 97 & AM284972 & 550 \\
\hline 19-BIADJ1D07 & 99 & EF088209 & 508 \\
\hline 20-BIADJ1G08 & 99 & AY691395 & 548 \\
\hline 21-BIADJ2B09 & 93 & AB247485 & 510 \\
\hline 22-BIADJ1G06 & 98 & AB116123 & 581 \\
\hline 23-BIADJ2E10 & 97 & EF075643 & 581 \\
\hline
\end{tabular}

Organismo

Ambiente - Autor

Comunidade microbiana solo da Califórnia-Cruz,K. et al ,2007

Sedimentos subsuperficiais contaminados urânio-Barns,S.M. et al., 2007

Diversidade bacteriana solo - Aspen -Lesaulnier,C.C. et al., 2007

Uncultured Acidobacteria bacterium clone R3.0071

Uncultured bacterium clone Amb_16S_1184

Uncultured bacterium clone CON1_E01

Uncultured soil bacterium clone HSB OF53_A12RU

Uncultured bacterium clone NR.087

Uncultured bacterium clone FCPU392

Uncultured soil bacterium clone CWT ST01_B01 Uncultured bacterium clone FCPS485

Uncultured Verrucomicrobia bacterium clone GASP-WDOS1_H02

Uncultured organism clone ctg_CGOGA40

Uncultured bacterium clone NR.03

Uncultured Verrucomicrobia bacterium clone DOK BIODYN clone302

Uncultured Verrucomicrobiales bacterium clone $455 \mathrm{~T} 3$

Uncultured Rhodoplanes sp. clone GASP-WA2S3_F10 Uncultured bacterium clone GR6

Streptomyces atroaurantiacus strain NRRL B-24282

Uncultured Firmicutes bacterium clone GASP-WC2W3_C12

Uncultured bacterium clone DUNssu320 (+1C) (OTU\#083)

Uncultured Gemmatimonadetes bacterium clone AKYH1258

Uncultured low $\mathrm{G}+\mathrm{C}$ Gram-positive bacterium Uncultured bacterium clone FCPU48

Uncultured Gemmatimonadetes bacterium clone Elev_16S_1029

Uncultured soil bacterium clone HSB OF51_F06

Uncultured alpha proteobacterium clone GASP-WB1S2_C09 Uncultured bacterium clone FCPP475

Uncultured Hyphomicrobiaceae bacterium clone Amb_16S_1041

Uncultured soil bacterium clone $52-2$

Uncultured bacterium clone: RB307

Uncultured soil bacterium clone 557-2

Uncultured Methylocystaceae bacterium clone Amb 16S 826 Uncultured bacterium clone i3

Uncultured bacterium clone Molly44Alpha
Uncultured bacterium clone CON5 A06

Uncultured alpha proteobacterium clone GASP-WB1S2_G06 Uncultured bacterium clone 25

Uncultured gamma proteobacterium clone GASP-WB2S2_B01

Uncultured soil bacterium clone CWT SM01_G02

Uncultured gamma proteobacterium clone NMW308WL

Uncultured bacterium clone Amb_16S_668 Uncultured bacterium clone $8 \mathrm{M} 73$

Burkholderia nodosa, isolate R-2548 Burkholderia gladioli strain S
Burkholderia sp. hpud 12

Uncultured bacterium clone:Run-SP97 Bacillus sphaericus strain:S33

Uncultured Bacillus sp. clone GASP-WDOS3_D11
Comunidades bacterianas em solos arroz-Upchurch, R, et al, 2006

Diversidade bacteriana em solos de floresta-Upchurch, R. et al, 2006

Diversidade microbiana de solo - Macalady J.L. et al, 2007

Diversidade microbiana de solo - Macalady,J.L. et al., 2007

Diversidade bacteriana em solos de floresta-Upchurch,R. et al., 2006

Comunidade microbiana solo da Califórnia-Cruz,K. et al.,2007

Diversidade bacteriana em solos de pastagem e agricultura- Piedmont EUA - Jangid,K. et al.,2006 Penn,K. et al., 2006

Diversidade microbiana de solo - Macalady,J.L. et al., 2007

Diversidade bacteriana de solos-Hartmann,M. and Widmer,F., 2006 Microrganismos de solo -Weber,K.A. et al., 2005

Diversidade bactering

Comunidade bacteriana de solo-Mummey,D.L. and Stahl,P.D., 2002

Comunidade microbiana solo da Califórnia-Cruz,K. et al.,2007 Streptomices - Goodfellow,M. et al., 2006

agem e agricultura- Piedmont EUA - Jangid,K. et al.,2006 Comunidade bacteriana -Rosch,C. and Bothe,H., 2005

Comunidade microbiana-Tringe,S.G. et al., 2005

Diversidade bacteriana solos Califórnia-LaMontagne,M.G. et al., 2003

Comunidade microbiana solo da Califórnia-Cruz,K. et al.,2007

Diversidade bacteriana solo - Aspen -Lesaulnier,C.C. et al., 2007

Diversidade bacteriana em solos de floresta-Upchurch,R. et al., 2006

Diversidade bacteriana em solos de pastagem e agricultura- Piedmont EUA - Jangid,K. et al.,2006

Comunidade microbiana solo da Califórnia-Cruz,K. et al.,2007 Terra Preta - Amazônia - Kim,J.-S. et al., 2006

Diversidade bacteriana de rizosfera - Nakamura,Y. et al., 2005 Terra Preta - Amazônia - Kim,J.-S. et al., 2006

Diversidade bacteriana solo - Aspen -Lesaulnier,C.C. et al., 2007

Diversidade microbiana de solo -Huang,T.et al., 2006

$$
\text { Morales,S.E.et al., } 2006
$$

Comunidades bacterianas em solos arroz-Upchurch,R. et al., 2006

Diversidade bacteriana em solos de pastagem e agricultura- Piedmont EUA - Jangid,K. et al.,2006 Diversidade bacteriana dem solos -Toljander,J.F.et al., 2006

Diversidade bacteriana em solos de pastagem e agricultura- Piedmont EUA - Jangid,K. et al.,2006

Comunidades bacterianas em solos de floresta-Upchurch,R. et al., 2006

Diversidade bacteriana solos de floresta da Colômbia-Axelrood,P.E. et al., 2004

Diversidade bacteriana solo - Aspen -Lesaulnier,C.C. et al., 2007

Diversidade bacteriana em solos tropicais -Roose-Amsaleg,C. et al.,2004 Bactérias de leguminosas - Chen,W.M. et al., 2007 Burkholderia - Nandakumar,R. et al.,2006

Burkholderia - Barrett,C.F. and Parker,M.A., 2006

Organismos acumuladores de polifosfatos-Lee,M. et al., 2006

Isolados de bacterias gram-positivas -Ohnishi,A., 2003

Diversidade bacteriana em solos de pastagem e agricultura- Piedmont EUA - Jangid,K. et al.,2006 
Anexo A - Resultados das comparações das seqüências parciais da região 16S rRNA obtidas em amostras de solo Terra Preta Antropogênica e respectivos solos adjacentes da região Amazônica, com as amostras depositadas no GeneBank utilizando o programa Blast

(continuação)

\begin{tabular}{|c|c|c|c|c|}
\hline Filotipo/Clone & ID \% & No. acesso & pb & evalt \\
\hline 24-BIADJ2D04 & 93 & AB089840 & 528 & 0.0 \\
\hline 25-BIADJ1C06 & 95 & DQ129081 & 490 & 0.0 \\
\hline 26-BIADJ3H02 & 93 & EF393471 & 623 & 0.0 \\
\hline 27-BIADJ2D12 & 97 & EF019112 & 559 & 0.0 \\
\hline 29-BIADJ2E12 & 88 & AM180156 & 604 & 0.0 \\
\hline 30-BIADJ2G11 & 89 & DQ129128.2 & 544 & 0.0 \\
\hline 31-BIADJ2H08 & 87 & EF516921 & 562 & $1 e-17$ \\
\hline 32-BIADJ2H05 & 92 & EF516921 & 640 & 0.0 \\
\hline 33-BIADJ2C03 & 90 & AY917970 & 513 & 0.0 \\
\hline 34-BIADJ2A04 & 97 & AY963342 & 577 & 0.0 \\
\hline 35-BIADJ2D05 & 96 & DQ830459 & 567 & 0.0 \\
\hline 36-BIADJ3G12 & 96 & EF020199 & 478 & 0.0 \\
\hline 37-BIADJ2A05 & 95 & AJ863210 & 633 & 0.0 \\
\hline 38-BIADJ3D06 & 97 & EF074580 & 530 & 0.0 \\
\hline 39-BIADJ1A01 & 88 & AY963441 & 674 & 0.0 \\
\hline 40-BIADJ1H03 & 96 & EF516796 & 670 & 0.0 \\
\hline 41-BIADJ1E08 & 95 & EF588354 & 608 & 0.0 \\
\hline 42-BIADJ2F12 & 95 & EF516715 & 595 & 0.0 \\
\hline 43-BIADJ3E09 & 98 & AY917539 & 481 & 0.0 \\
\hline 44-BIADJ1C01 & 98 & AY963487 & 708 & 0.0 \\
\hline 45-BIADJ1D06 & 95 & DQ451511 & 655 & 0.0 \\
\hline 46-BIADJ1H04 & 97 & EF588337 & 601 & 0.0 \\
\hline 47-BIADJ2E02 & 95 & AY913248 & 562 & 0.0 \\
\hline 48-BIADJ2G05 & 95 & DQ129214 & 503 & 0.0 \\
\hline 49-BIADJ1E01 & 96 & AY 963440 & 685 & 0.0 \\
\hline 50-BIADJ3C01 & 96 & AY963440 & 645 & 0.0 \\
\hline 51-BIADJ1G02 & 99 & DQ128689 & 541 & 0.0 \\
\hline 52-BIADJ1G01 & 95 & EF075795 & 688 & 0.0 \\
\hline 53-BIADJ1C04 & 97 & AJ519366 & 612 & 0.0 \\
\hline 54-BIADJ3H08 & 96 & AF529322 & 506 & 0.0 \\
\hline 55-BIADJ1H11 & 95 & AY913231 & 655 & 0.0 \\
\hline 56-BIADJ1F08 & 95 & EF588353 & 532 & 0.0 \\
\hline 57-BIADJ2A12 & 95 & AY724006.2 & 604 & 0.0 \\
\hline 58-BIADJ1F07 & 96 & DQ129049 & 539 & 0.0 \\
\hline 59-BIADJ3B06 & 97 & EF072430 & 536 & 0.0 \\
\hline 60-BIADJ2G09 & 96 & DQ664073 & 533 & 0.0 \\
\hline 61-BIADJ1B08 & 98 & EF516749 & 589 & 0.0 \\
\hline 62-BIADJ1D08 & 89 & AJ295657 & 603 & 0.0 \\
\hline 63-BIADJ2G07 & 89 & DQ128522 & 527 & 0.0 \\
\hline 64-BIADJ2C08 & 87 & AY694611 & 496 & $2 \mathrm{e}-16$ \\
\hline 65-BIADJ3C05 & 98 & EF457325 & 563 & 0.0 \\
\hline 66-BIADJ1G09 & 98 & EF516748 & 524 & 0.0 \\
\hline 67-BIADJ2B06 & 91 & AY963472 & 591 & 0.0 \\
\hline 68-BIADJ3A06 & 93 & EF457449 & 600 & \\
\hline 69-BIADJ3G11 & 93 & EF457307 & 490 & 0.0 \\
\hline 70-BIADJ1A05 & 97 & DQ451448 & 567 & 0.0 \\
\hline 71-BIADJ2B08 & 96 & DQ830713 & 528 & 0.0 \\
\hline 72-BIADJ3C08 & 94 & AY988634 & 525 & 0.0 \\
\hline
\end{tabular}

Organismo

Isolado de bacteria termo-acidofilica-Goto,K. et al., 2007

Uncultured soil bacterium clone CWT SM02 E08 Uncultured bacterium clone ORSFES g05 Ktedobacter racemifer strain SOSP $1-21$ Uncultured soil bacterium clone CWT SM03 H07 Uncultured bacterium clone FCPN634 Uncultured bacterium clone FCPN634 Uncultured bacterium clone 1982a-46 Uncultured bacterium clone AH49 Uncultured bacterium clone AH49
Uncultured bacterium clone CON6 G01 Uncultured bacterium clone Elev $16 \overline{\mathrm{S}} 1673$ Uncultured bacterium clone 20BSU7
Uncultured bacterium clone Elev_16_1673

Uncultured Acidobacteria bacterium clone GASP-WC1S3 D04 Uncultured bacterium clone BS03 Uncultured bacterium clone FCPT625

Uncultured Acidobacteria bacterium clone WSD-028

Uncultured bacterium clone FCPT492

Uncultured bacterium clone 1790d-13

Uncultured bacterium clone BS50

Uncultured bacterium clone FAC72

Uncultured Acidobacteria bacterium clone WSD-01

Uncultured forest soil bacterium clone DUNssu029

Uncultured soil bacterium clone CWT ST03 C05G Uncultured bacterium clone BS02
Uncultured bacterium clone BS02

Uncultured soil bacterium clone HSB NT21 H10RU Uncultured Firmicutes bacterium clone GASP-WDOW2 D12 Uncultured Holophaga sp. clone JG37-AG-13

Uncultured Acidobacterium group bacterium clone CLi114

Uncultured forest soil bacterium clone DUNssu010

Uncultured Acidobacteria bacterium clone WSD-027

Uncultured bacterium clone DUNssu1 16 (-1B) (OTU\#118)

Uncultured soil bacterium clone CWT SM01 E02

Uncultured Acidobacteria bacterium clone GASP-Ā1W2 G05 Uncultured bacterium clone $9 \mathrm{~V} 46$ Uncultured bacterium clone FCPS394 Uncultured bacterium KF/GS-JG36-31

Uncultured soil bacterium clone CWT CU03 G10 Uncultured Holophaga sp. clone JAB SMS 87 Uncultured Acidobacteria bacterium clone D13.0001 Uncultured bacterium clone FCPN74 Uncultured bacterium clone BS34

Uncultured Acidobacteria bacterium clone R3.0048

Uncultured Acidobacteria bacterium clone T10.003

Uncultured Acidobacteria bacterium clone $\mathrm{FAC} 9$ Uncultured bacterium clone PAS1_C05

Uncultured soil bacterium clone L1AD0
Comunidades bacterianas em solos de floresta-Upchurch,R. et al., 2006

Microrganismos de sedimentos Rio Ohio-D'Angelo,E.M. and Nunez,A.E., 2007 Diversidade bacteriana solo - Aspen -Lesaulnier,C.C. et al, 2007 Bactérias de solo-Cavaletti,L. et al., 2006

Comunidades bacterianas em solos de floresta-Upchurch,R. et al., 2006 Comunidade microbiana solo da Califórnia-Cruz,K Comunidade microbiana solo da California-Cruz,K. et al.,2007 Comunidade microbiana em solos vulcões Hawai-Gomez-Alvarez,V. and Nuesslein,K., 2005

Comunidades bacterianas em solos de floresta (China)-Chan,O.C. et al., 2006 Comunidades bacterianas em solos arroz-Upchurch,R. et al., 2006 Diversidade bacteriana solo - Aspen -Lesaulnier,C.C. et al., 2007 Comunidade bacteriana de solos-Graff,A. and Conrad,R., 200

id,K. et al.,2006

Comunidades bacterianas em solos de floresta (China)-Chan,O.C. et al., 2006 Comunidade microbiana solo da Califórnia-Cruz,K. et al.,2007 Acidobacteria - Cho,J.-C. and Lee,S.-H., 2007

Comunidade microbiana solo da Califórnia-Cruz,K. et al.,2007

omunidade microbiana em solos de vulcões Hawai-Gomez-Alvarez,V. and Nuesslein,K., 2005

Comunidades bacterianas em solos de floresta (China)-Chan,O.C. et al., 2006

Comunidade bacteriana solo de Taiwan-Tsai,S.-H. et al., 2006 Acidobacteria - Cho,J.-C. and Lee,S.-H., 2007

Diversidade bacteriana solo de floresta - Alemanha -Roesch,C. et al.,200

Comunidades bacterianas em solos de floresta-Upchurch,R. et al., 2006

Comunidades bacterianas em solos de floresta (China)-Chan,O.C. et al., 2006

Comunidades bacterianas em solos de floresta (China)-Chan,O.C. et al., 2006

Comunidades bacterianas em solos de floresta-Upchurch,R. et al., 2006

Diversidade bacteriana em solos de pastagem e agricultura- Piedmont EUA - Jangid,K. et al.,2006 Diversidade bacteriana-Geissler,A., 2002

Populacao microbiana -Carroll,A.B. and Zinder,S.H., 2002

Diversidade bacteriana solo de floresta - Alemanha-Roesch,C. et al.,2005 Acidobacteria - Cho J-C.C. and Lee,S.-H. 2007

Comunidade bacteriana - Rosch, $\mathrm{C}$. and Bothe $\mathrm{H}_{\mathrm{H}}, 2005$

Comunidades bacterianas em solos de floresta-Upchurch,R. et al., 2006 Diversidade bacteriana em solos de pastagem e agricultura- Piedmont EUA - Jangid,K. et al. 2006

Comunidades microbianas sedimentos contaminados petróleo-Allen.J.P. et al, 2007 Comunidade microbiana solo da Califórnia-Cruz,K. et al.,2007 Diversidade microbiana de solos-Selenska-Pobell,S. et al., 2004 Comunidades bacterianas em solos de floresta-Upchurch,R. et al., 2006 Comunidades bacterianas em solos-Val-Moraes,S.P. et al., 2005 Sedimentos subsuperficiais contaminados urânio - Barns,S.M. et al., 2007 Comunidade microbiana solo da Califórnia-Cruz,K. et al.,2007

Comunidades bacterianas em solos de floresta (China)-Chan,O.C. et al., 2006 Sedimentos subsuperficiais contaminados urânio - Barns,S.M. et al., 2007 edimentos subsuperficiais contaminados urânio - Barns,S.M. et al., 2007 Comunidade bacteriana solo de Taiwan-Tsai,S.-H. et al., 2006 Comunidades bacterianas em solos arroz-Upchurch,R. et al., 2006 Bacteria de solo-Schloss,P.D. and Handelsman,J., 2005 
Anexo A - Resultados das comparações das seqüências parciais da região 16S rRNA obtidas em amostras de solo Terra Preta Antropogênica e respectivos solos adjacentes da região Amazônica, com as amostras depositadas no GeneBank utilizando o programa Blast

(continuação)

\begin{tabular}{|c|c|c|c|c|}
\hline Filotipo/Clone & ID \% & No. acesso & pb & evalue \\
\hline 73-BIADJ3B10 & 96 & DQ664060 & 523 & 0.0 \\
\hline 74-BIADJ2H09 & 92 & DQ829967 & 645 & 0.0 \\
\hline 75-BIADJ1B05 & 96 & EF018770 & 452 & 0.0 \\
\hline 76-BIADJ3F08 & 96 & EF494374 & 440 & 0.0 \\
\hline 77-BIADJ1E02 & 93 & EF018550 & 651 & 0.0 \\
\hline 78-BIADJ2F11 & 89 & DQ663853 & 562 & 0.0 \\
\hline 79-BIADJ2A06 & 96 & EF457391 & 657 & 0.0 \\
\hline 80-BIADJ3A08 & 97 & EF075497 & 558 & 0.0 \\
\hline 81-BIADJ3D07 & 96 & EF457391 & 453 & 0.0 \\
\hline 82-BIADJ2C09 & 96 & EF515877 & 553 & 0.0 \\
\hline 83-BIADJ2H06 & 97 & EF457379 & 618 & 0.0 \\
\hline 84-BIADJ1E10 & 95 & DQ450710 & 609 & 0.0 \\
\hline 85-BIADJ1F01 & 98 & AM697576 & 680 & 0.0 \\
\hline 86-BIADJ2F01 & 99 & AY 963503 & 529 & 0.0 \\
\hline 87-BIADJ2D11 & 98 & AY 963488 & 545 & 0.0 \\
\hline 88-BIADJ2E11 & 96 & EF516950 & 545 & 0.0 \\
\hline 89-BIADJ2D03 & 97 & AY963478 & 466 & 0.0 \\
\hline 90-BIADJ2E03 & 90 & EF516776 & 579 & 0.0 \\
\hline 91-BIADJ3D04 & 94 & EF516272 & 576 & 0.0 \\
\hline 92-BIADJ1G03 & 96 & AY326547 & 568 & 0.0 \\
\hline 93-BIADJ1F06 & 97 & AY326548 & 571 & 0.0 \\
\hline 94-BIADJ1B04 & 97 & AY963381 & 620 & 0.0 \\
\hline 95-BIADJ2C02 & 97 & B240245 & 582 & 0.0 \\
\hline 96-BIADJ1C02 & 97 & AY963393 & 698 & 0.0 \\
\hline 97-BIADJ2F06 & 98 & AY326547 & 586 & 0.0 \\
\hline 98-BIADJ3C06 & 98 & AY963452 & 595 & 0.0 \\
\hline 99-BIADJ1B03 & 97 & AY963452 & 568 & 0.0 \\
\hline 100-BIADJ1B10 & 98 & EF018396 & 626 & 0.0 \\
\hline 101-BIADJ1F05 & 96 & EF019080 & 622 & 0.0 \\
\hline 102-BIADJ2B12 & 97 & AF431502 & 526 & 0.0 \\
\hline 103-BIADJ2B01 & 97 & AY963443 & 525 & 0.0 \\
\hline 104-BIADJ2D02 & 95 & DQ453805 & 662 & 0.0 \\
\hline 105-BIADJ3E07 & 94 & EF074473 & 630 & 0.0 \\
\hline 106-BIADJ1D03 & 95 & EF074473 & 500 & 0.0 \\
\hline 107-BIADJ3F05 & 93 & AB254785 & 576 & 0.0 \\
\hline 108-BIADJ2G10 & 93 & AB254785 & 608 & 0.0 \\
\hline 109-BIADJ2C01 & 94 & EF074473 & 525 & 0.0 \\
\hline 110-BIADJ3C12 & 96 & AJ519370 & 608 & 0.0 \\
\hline 111-BIADJ2D01 & 91 & AB254785 & 501 & 0.0 \\
\hline 112-BIADJ3A04 & 92 & AB254785 & 659 & 0.0 \\
\hline 113-BIADJ3G02 & 93 & AB254785 & 544 & 0.0 \\
\hline 114-BIADJ3B12 & 93 & AY723995 & 519 & 0.0 \\
\hline 115-BIADJ3A02 & 96 & AY913495 & 667 & 0.0 \\
\hline 116-BIADJ3B08 & 95 & AY913495 & 597 & 0.0 \\
\hline 117-BIADJ3H10 & 93 & EF457491 & 593 & 0.0 \\
\hline 118-BIADJ3D12 & 92 & AB238783 & 565 & 0.0 \\
\hline 119-BIADJ3F12 & 92 & AB238783 & 537 & 0.0 \\
\hline 120-BIADJ3A07 & 93 & AB238783 & 620 & 0.0 \\
\hline
\end{tabular}

Organismo

Ambiente - Autor

Uncultured bacterium clone $9 \mathrm{~V} 32$

Uncultured Acidobacteriaceae bacterium clone Amb_16S_1232 Uncultured bacterium clone NR27

Uncultured bacterium clone Amb_16S_812 Uncultured bacterium clone $5 \mathrm{~V} 84$

Uncultured Acidobacteria bacterium clone BGB.0024

Uncultured Acidobacteria bacterium clone GASP-WDOS2 G12 Uncultured Acidobacteria bacterium clone BGB.0024 Uncultured bacterium clone FCPT602

Uncultured Acidobacteria bacterium clone BGA.0027 Uncultured Acidobacteria bacterium clone C10_WMSP1

Uncultured bacterium isolate BF0002D087 Uncultured bacterium clone BS67

Uncultured bacterium clone BS51

Uncultured bacterium clone FCPP719

Uncultured bacterium clone BS40

Uncultured bacterium clone FCPP686

Uncultured bacterium clone FCPN628

Uncultured soil bacterium clone 55-2

Uncultured soil bacterium clone 157-2

Uncultured bacterium clone AS12

Uncultured bacterium clone: BS064

Uncultured bacterium clone AS25

Uncultured soil bacterium clone $55-2$

Uncultured bacterium clone BS14

ncultured bacterium clone Amb 16S 1009

Uncultured bacterium clone Amb_16S_1009

Uncultured Acidobacterium group bacterium clone C47.36PG Uncultured bacterium clone BS05

Uncultured Acidobacteria bacterium clone i5

Uncultured Acidobacteria bacterium clone GASP-WC1S2 C01

Uncultured Acidobacteria bacterium clone GASP-WC1S2_C01

Uncultured bacterium clone: TakashiA-B36

Uncultured bacterium clone: TakashiA-B36

Uncultured Acidobacteria bacterium clone GASP-WC1S2 C01

Uncultured Holophaga sp. clone JG37-AG-40

Uncultured bacterium clone: TakashiA-B36

Uncultured bacterium clone: TakashiA-B36

Uncultured bacterium clone: TakashiA-B36

Uncultured bacterium clone DUN1_63-778_+B08

Uncultured forest soil bacterium clone DUNssu295

Uncultured forest soil bacterium clone DUNssu295

Uncultured Acidobacteria bacterium clone RP7.0006

Uncultured bacterium clone: HSM-SS-020

Uncultured bacterium clone: HSM-SS-020

Uncultured bacterium clone: HSM-SS-020
Comunidades microbianas-sedimentos contaminados petróleo-Allen,J.P. et al., 2007
Comunidades bacterianas em solos arroz-Upchurch,R. et al., 2006

Diversidade bacteriana solo - Aspen -Lesaulnier,C.C. et al, 2006

Diversidade microbiana - Aspen -Lesaunier,C.C. et al., 2007

Diversidade bacteriana solo - Aspen -Lesaulnier,C.C. et al., 2007

Comunidades microbianas-sedimentos contaminados petróleo-Allen,J.P. et al., 2007

Sedimentos subsuperficiais contaminados urânio - Barns,S.M. et al., 2007

Diversidade bacteriana em solos de pastagem e agricultura- Piedmont EUA - Jangid,K. et al.,2006

Sedimentos subsuperficiais contaminados urânio - Barns,S.M. et al., 2007 Comunidade microbiana solo da Califórnia-Cruz,K. et al.,200

Sedimentos subsuperficiais contaminados urânio -Barns,S.M. et al., 2007

Diversidade microbiana-Costello,E.K. and Schmidt,S.K., Diversidade bacteriana - Rintala,H. et al., 2007

Comunidades bacterianas em solos de floresta (China)-Chan,O.C. et al., 2006 Comunidades bacterianas em solos de floresta (China)-Chan,O.C. et al., 2006 Comunidade microbiana solo da Califórnia-Cruz,K. et al.,2007

Comunidades bacterianas em solos de floresta (China)-Chan,O.C. et al., 2006

Comunidade microbiana solo da Califórnia-Cruz,K. et al.,2007

Comunidade microbiana solo da Califórnia-Cruz,K. et al.,2007 Terra Preta - Amazônia - Kim,J.-S. et al., 2006 Terra Preta - Amazônia - Kim,J.-S. et al., 2006

Comunidades bacterianas em solos de floresta (China)-Chan,O.C. et al., 2006 Diversidade bacteriana de rizosfera - Nakamura, Y. et al., 2005

Comunidades bacterianas em solos de floresta (China)-Chan,O.C. et al., 2006 Terra Preta - Amazônia - Kim,J.-S. et al., 2006

Comunidades bacterianas em solos de floresta (China)-Chan,O.C. et al., 2006

Comunidades bacterianas em solos de floresta (China)-Chan,O.C. et al., 2006

Diversidade bacteriana solo - Aspen -Lesaulnier,C.C. et al., 2007

Diversidade bacteriana floresta da Colômbia-Chow,M.L. et al, 2004

Comunidades bacterianas em solos de floresta (China)-Chan, O.C. et al., 2006 Diversidade microbiana de solo -Huang, T et al, 2006

Diversidade bacterian enn solos de pastage e agriculura-Piedmont EUA - Jangid,K et al,2006 Bacterias de sedimentos-Yoshida,H. et al., 2006 Bacterias de sedimentos-Yoshida, $\mathrm{H}$ et al, 2006 solos de pastagem e agricultura- Piedmont EUA - Jangid,K. et al.,2006 Diversidade bacteriana-Geissler,A., 2002 Bacterias de sedimentos-Yoshida,H. et al., 2006 Bacterias de sedimentos-Yoshida,H. et al., 2006 Bacterias de sedimentos-Yoshida,H. et al., 2006 Comunidade bacteriana - Rosch,C. and Bothe,H., 2005

Diversidade bacteriana solo de floresta - Alemanha -Roesch,C. et al.,2005 Diversidade bacteriana solo de floresta - Alemanha -Roesch,C. et al.,200

Sedimentos subsuperficiais contaminados urânio-Barns,S.M. et al., 2007

Diversidade bacteriana - solos-Akiyama,M. et al., 2006

Diversidade bacteriana - solos-Akiyama,M. et al., 2006

Diversidade bacteriana - solos-Akiyama,M. et al., 2006 
Anexo A - Resultados das comparações das seqüências parciais da região 16S rRNA obtidas em amostras de solo Terra Preta Antropogênica e respectivos solos adjacentes da região Amazônica, com as amostras depositadas no GeneBank utilizando o programa Blast

(continuação)

\begin{tabular}{|c|c|c|c|c|}
\hline Filotipo/Clone & ID \% & No. acesso & pb & evalue \\
\hline 121-BIADJ3E08 & 90 & AY989453 & 531 & 0.0 \\
\hline 122-BIADJ2F08 & 95 & AY703471 & 510 & 0.0 \\
\hline 123-BIADJ2G08 & 97 & EF072179 & 529 & 0.0 \\
\hline 124-BIADJ2D07 & 89 & AJ009448 & 585 & 0.0 \\
\hline 125-BIADJ3B04 & 97 & AY562343 & 510 & 0.0 \\
\hline 126-BIADJ1D11 & 92 & AF392696 & 482 & 0.0 \\
\hline 127-BIADJ1H06 & 89 & AB128874 & 602 & 0.0 \\
\hline 128-BIADJ2H01 & 92 & DQ663802 & 622 & 0.0 \\
\hline 129-BIADJ2B04 & 97 & EF516526 & 588 & 0.0 \\
\hline 130-BIADJ1F04 & 93 & EF018149 & 544 & 0.0 \\
\hline 131-BIADJ2F05 & 96 & DQ663840 & 518 & 0.0 \\
\hline 132-BIADJ1A11 & 98 & DQ451477 & 656 & 0.0 \\
\hline 133-BIADJ2E04 & 90 & EF455198 & 531 & 0.0 \\
\hline 134-BIADJ1F02 & 98 & EF019121 & 594 & 0.0 \\
\hline 01- MITPA1A08 & 87 & AY711539 & 514 & $3 e-169$ \\
\hline 02-MITPA2E10 & 85 & DQ444026 & 526 & $4 \mathrm{e}-148$ \\
\hline 03-MITPA1F02 & 96 & DQ664135 & 647 & 0.0 \\
\hline 04-MITPA1E03 & 96 & DQ444026 & 578 & 0.0 \\
\hline 05-МITPA3В05 & 92 & AY326579 & 543 & 0.0 \\
\hline 06-MITPA2C02 & 92 & AJ518798 & 554 & 0.0 \\
\hline 07-MITPA1G10 & 94 & EF516565 & 596 & 0.0 \\
\hline 08-MITPA3D08 & 97 & DQ154514 & 482 & 0.0 \\
\hline 09-MITPA1H04 & 90 & EF459921 & 560 & 0.0 \\
\hline 10-MITPA1A01 & 95 & AY 177760 & 654 & 0.0 \\
\hline 11-MITPA1F01 & 96 & EF073995 & 600 & 0.0 \\
\hline 12-MITPA1B09 & 96 & EF073995 & 487 & 0.0 \\
\hline 13-MITPA1G07 & 94 & AY 177760 & 531 & 0.0 \\
\hline 14-MITPA3H04 & 94 & DQ827894 & 508 & 0.0 \\
\hline 15-MITPA1C07 & 91 & AY 326582 & 587 & 0.0 \\
\hline 16-MITPA2G06 & 98 & AY 326582 & 555 & 0.0 \\
\hline 17-MITPA1C04 & 96 & DQ499285 & 638 & 0.0 \\
\hline 18-MITPA1H03 & 99 & EF074139 & 671 & 0.0 \\
\hline 19-MITPA2F04 & 98 & AY921692 & 618 & 0.0 \\
\hline 20-МITPA3С09 & 96 & AY493929 & 613 & 0.0 \\
\hline 21-MITPA3C12 & 97 & AJ252662 & 599 & 0.0 \\
\hline 22-MITPA2D10 & 97 & DQ444017 & 648 & 0.0 \\
\hline 23-МITPA2H03 & 96 & DQ648910 & 615 & 0.0 \\
\hline 24-MITPA2H04 & 95 & $\mathrm{AF} 431512$ & 498 & 0.0 \\
\hline 25-МITPA3Н11 & 96 & EF457304 & 600 & 0.0 \\
\hline 26-МITPA3B10 & 97 & EF455179 & 504 & 0.0 \\
\hline 27-MITPA1A04 & 96 & AY 150900 & 625 & 0.0 \\
\hline 28-MITPA1C 11 & 96 & EF516240 & 596 & 0.0 \\
\hline 29-МITPA3С 04 & 96 & AY989496 & 571 & 0.0 \\
\hline 30-MITPA2B06 & 97 & B273816 & 611 & 0.0 \\
\hline 31-MITPA1B03 & 95 & AM158372 & 534 & 0.0 \\
\hline 32-MITPA2G04 & 99 & DQ532211 & 539 & 0.0 \\
\hline 33-MITPA1A02 & 96 & AJ863260 & 659 & 0.0 \\
\hline 34-MITPA3D04 & 95 & DQ128762 & 533 & 0.0 \\
\hline
\end{tabular}

Organismo

Ambiente - Autor

Uncultured soil bacterium clone L1A3B12
Uncultured bacterium isolate ALT6

Uncultured proteobacterium clone GASP-WA1S3_H08

uncultured bacterium SJA-4 clone SJA-4

Uncultured beta proteobacterium clone Sta2-46

Uncultured bacterium clone LAH4

Uncultured bacterium clone: 1174-1091-4

Uncultured bacterium clone $5 \mathrm{~V} 13$

Uncultured bacterium clone FCPP428

Uncultured bacterium clone Amb_16S_484

Uncultured bacterium clone $5 \mathrm{~V} 63$

Uncultured Nitrospirae bacterium clone FAC 38

Uncultured soil bacterium clone $\mathrm{C} 57-\mathrm{Fw}$

Uncultured Verrucomicrobia bacterium clone Amb_16S_1750

Uncultured proteobacterium clone SIMO-2173

Uncultured bacterium clone $\mathrm{PH} 1-25$

Uncultured bacterium clone 9S39

Uncultured bacterium clone $\mathrm{PH} 1-25$

Uncultured soil bacterium clone $221-1$

Uncultured delta proteobacterium clone JG37-AG-113

Uncultured bacterium clone FCPP581

Uncultured soil bacterium clone RFS-C197

Uncultured bacterium clone $246 \mathrm{~b} 2$

Uncultured Acidobacteria bacterium isolate $5 \mathrm{~g} 10$

Uncultured Acidobacteria bacterium clone GASP-WB2S3_G11

Uncultured Acidobacteria bacterium clone GASP-WB2S3_

Uncultured Acidobacteria bacterium isolate $5 \mathrm{~g} 10$

Uncultured Acidobacteria bacterium clone DOK_BIODYN
Uncultured soil bacterium clone 31-1

Uncultured bacterium clone $31-1$

Uncultured Acidobacteria bacterium clone GASP-WB2W1 E12

Uncultured Acidobacteria bacterium clone AKYG64

Uncultured soil bacterium clone 284

Agricultural soil bacterium clone SC-I-86

Uned bacterium clone PH1-16

Uncultured Acidobacteria bacterium clone lhad 11

Uncultured Acidobacterium group bacterium clone S526PG

cultured Acidobacteria bacterium clone T10.
Uncultured soil bacterium clone C $38-\mathrm{Fw}$

uncultured Acidobacteriales bacterium clone GR20 Uncultured bacterium clone FCPS597

Uncultured soil bacterium clone L1A3G09

Uncultured bacterium clone: EXP-16S-13C-light-Clone_24 Uncultured bacterium partial S412D

Uncultured bacterium clone JSC7-22

Uncultured bacterium clone 26BSF

Uncultured soil bacterium clone HSB NT51_F07
Bacteria de solo-Schloss,P.D. and Handelsman,J., 2005

Comunidade de acidobacterias em cavernas-Zimmermann,J. et al., 2005

Diversidade bacteriana em solos de pastagem e agricultura- Piedmont EUA - Jangid,K. et al.,2006

Microrganismos anaeróbicos-von Wintzingerode,F. et al., 2003 Diversidade bacteriana de rio-Cottrell,M.T. et al., 2005

Analise genetica microbiana de rizosferas-Sakano,Y., Strom,P. and Kerkhof,L., 2004

Comunidade microbiana de sedimentos-Murakami,Y. and Naganuma,T., 2005

Comunidade microbiana solo da Califórnia-Cruz,K. et al.,2007

Diversidade bacteriana solo - Aspen -Lesaulnier,C.C. et al., 2007

Comunidades microbianas de sedimentos contaminados petróleo - Allen,J.P. et al., 2007

Comunidade bacteriana solo de Taiwan-Tsai,S.-H. et al., 2006

Diversidade bacteriana - solo contaminado Hg (EUA)-Oregaard,G. et al., 2007

Diversidade bacteriana solo - Aspen -Lesaulnier,C.C. et al., 2007

Diversidade de procariotos de ambiente salino-Moran,M.A. et al., 2007

Comunidade microbiana de sedimentos de rio-Zhao,Y.-G. et al., 2006

Comunidade microbiana de sedimentos contaminados com petróleo - Allen,J.P. et al., 2007

Comunidade microbiana de sedimentos de rio-Zhao,Y.-G. et al., 2006

Terra Preta - Amazônia - Kim,J.-S. et al., 2006

Diversidade bacteriana-Geissler,A., 2002

Comunidade microbiana solo da Califórnia-Cruz,K. et al.,2007 Bacterias de solo-Becker,J.M. et al., 2005

População bacteriana em sedimento marinho-Edlund,A. et al., 2007

Diversidade bacteriana solo - Aspen-Lesaulnier,C.C. et al., 2007

Diversidade bacteriana em solos de pastagem e agricultura- Piedmont EUA - Jangid,K. et al.,2006 Diversidade bacteriana em solos de pastagem e agricultura- Piedmont EUA - Jangid,K. et al.,2006

Diversidade bacteriana de solo - Califórnia-LaMontagne,M.G. et al., 2003

Diversidade bacteriana de solo-Hartmann,M. and Widmer,F., 2006

$$
\begin{aligned}
& \text { Terra Preta - Amazônia - Kim,J.-S. et al., } 2006 \\
& \text { Terra Preta - Amazônia - Kim,J.-S. et al., } 2006
\end{aligned}
$$$$
\text { Terra Preta - Amazônia - Kim,J.-S. et al., } 2006
$$

Diversidade bacteriana em solos de pastagem e agricultura- Piedmont EUA - Jangid,K. et al.,2006

Estudo de comunidade microbiana-Tringe,S.G. et al., 2005

Comunidade bacteriana de solos-Kim,J.-S. and Crowley,D.E., 2003 Bacteria de solo agricola -Lukow,T., 2000

Comunidade microbiana de sedimentos de rio-Zhao,Y.-G. et al., 2006

Biodiversidade de bacteria em solo e rizosfera-Aguirre de Carcer,D. and Rivilla,R., 2006

Diversidade bacteriana floresta da Colômbia-Chow,M.L. et al., 2004

Sedimentos subsuperficiais contaminados urânio - Barns,S.M. et al., 2007

Diversidade bacteriana - solo contaminado Hg (EUA)-Oregaard,G. et al., 2007
Comunidade bacteriana de solo-Mummey,D.L. and Stahl,P.D., 2002

Comunidade microbiana solo da Califórnia-Cruz,K. et al.,2007

Bacteria de solo - Schloss,P.D. and Handelsman,J., 2005

Bacterias de solos úmidos - Murase,J. and Frenzel,P., 2006

Diversidade bacteriana de rizosfera-Saenz de Miera,L.E. et al, 2006

Diversidade microbiana de ambientes restritos-Dekas,A. et al., 2006

Comunidade bacteriana de solos-Graff,A. and Conrad,R., 2005

Comunidades bacterianas em solos de floresta e agricultura-Upchurch,R. et al., 2006 
Anexo A - Resultados das comparações das seqüências parciais da região 16S rRNA obtidas em amostras de solo Terra Preta Antropogênica e respectivos solos adjacentes da região Amazônica, com as amostras depositadas no GeneBank utilizando o programa Blast

(continuação)

\begin{tabular}{|c|c|c|c|}
\hline Filotipo/Clone & ID \% & No. acesso & pb \\
\hline 35-MITPA1E05 & 96 & AY921976 & 592 \\
\hline 36-MITPA2D09 & 98 & EF019772 & 550 \\
\hline 37-MITPA1B11 & 97 & EF074940 & 556 \\
\hline 38-MITPA3D03 & 96 & AJ863210 & 530 \\
\hline 39-МITPA3Н05 & 96 & AY922161 & 584 \\
\hline 40-MITPA1G02 & 96 & AY274124 & 480 \\
\hline 41-MITPA3B02 & 97 & EF455353 & 567 \\
\hline 42-MITPA3D07 & 97 & EF020075 & 536 \\
\hline 43-MITPA2F07 & 98 & EF018668 & 559 \\
\hline 44-MITPA2A11 & 97 & DQ297968 & 555 \\
\hline 45-МITPA3А07 & 96 & EF019378 & 546 \\
\hline 46-MITPA3G01 & 97 & DQ128991 & 533 \\
\hline 47-MITPA2C08 & 95 & EF457496 & 565 \\
\hline 48-MITPA2G12 & 96 & EF020199 & 520 \\
\hline 49-MITPA3В03 & 96 & EF075343 & 600 \\
\hline 50-MITPA2G08 & 96 & EF075144 & 599 \\
\hline 51-MITPA1E10 & 95 & EF457432 & 616 \\
\hline 52-MITPA3A11 & 94 & EF020199 & 491 \\
\hline 53-MITPA2B08 & 96 & DQ444056 & 550 \\
\hline 54-MITPA3А03 & 96 & DQ444056 & 526 \\
\hline 55-МITPA3С 03 & 96 & EF075273 & 550 \\
\hline 56-MITPA1C02 & 92 & EF457499 & 621 \\
\hline 57-MITPA2F05 & 93 & AY922154 & 555 \\
\hline 58-MITPA2F09 & 99 & EF392988 & 544 \\
\hline 59-MITPA2D08 & 98 & AF234142 & 549 \\
\hline 60-MITPA1B06 & 94 & AB293379 & 605 \\
\hline 61-MITPA3А02 & 97 & AJ863257 & 562 \\
\hline 62-MITPA2C11 & 97 & EF417737 & 554 \\
\hline 63-MITPA1F06 & 94 & EF417737 & 593 \\
\hline 64-MITPA2F03 & 95 & EF417737 & 554 \\
\hline 65-MITPA2E09 & 97 & AY221061 & 554 \\
\hline 66-МITPA3B12 & 97 & EF417702 & 525 \\
\hline 67-MITPA1F10 & 98 & EF417697 & 616 \\
\hline 68-MITPA1A03 & 96 & EF457318 & 609 \\
\hline 69-МITPA3С06 & 95 & EF457302 & 602 \\
\hline 70-МITPА3А05 & 93 & DQ453809 & 552 \\
\hline 71-MITPA2А07 & 95 & AB265877 & 554 \\
\hline 72-MITPA2G03 & 95 & DQ453809 & 544 \\
\hline 73-МITPA3А12 & 96 & EF393070 & 534 \\
\hline 74-MITPA2A 10 & 96 & EF393070 & 541 \\
\hline 75-MITPA1D11 & 94 & EF020088 & 553 \\
\hline 76-MITPA1B02 & 94 & DQ463266 & 634 \\
\hline 77-MITPA3G07 & 97 & AB201577 & 511 \\
\hline 78-MITPA2H09 & 95 & EF020088 & 510 \\
\hline 79-MITPA2B04 & 93 & AY989076 & 534 \\
\hline 80-MITPA3E11 & 93 & EF018479 & 567 \\
\hline 81-MITPA1F09 & 92 & AY989076 & 555 \\
\hline 82-MITPA1A06 & 91 & EF457381 & 543 \\
\hline
\end{tabular}

Organismo

Ambiente - Autor

Estudo de comunidade microbiana-Tringe,S.G. et al., 2005

ncultured Acidobacteria bacterium clone AKYG1709

Uncultured bacterium clone Elev $16 \mathrm{~S} 953$

Uncultured bacterium clone GASP-WC

Uncultured Acidobacteria bacterium clone AKYH853

Uncultured bacterium clone D114

Uncultured soil bacterium clone E27-Fw

Uncultured bacterium clone Elev_16S_1482

Uncultured bacterium clone Elev_16S_1482

Uncultured bacterium clone Amb_-
Uncultured soil bacterium clone UC7

Uncultured bacterium clone Elev 16S 606

Uncultured bacterium clone Elev_16S_606
Uncultured soil bacterium clone HSB OF53_G07

Uncultured Acidobacteria bacterium clone RP7.0015

Uncultured bacterium clone Elev_16S_1673

Uncultured proteobacterium clone GASP-WC2W3_B11

Uncultured Firmicutes bacterium clone GASP-WC2W 1 _A07

Uncultured Acidobacteria bacterium clone R2.0058

Uncultured bacterium clone Elev_16S_1673

Uncultured bacterium clone PH10-19
Uncultured bacterium clone PH10-19

Uncultured Ancultured bacterium clone PHID-19-WC2W2 D1

Uncultured Acidobacteria bacterium clone RP7.002

Uncultured Acidobacteria bacterium clone AKYH73

Uncultured bacterium clone ORS25C_d04
Uncultured bacterium \#0319-7F19

Uncultured Acidobacteria bacterium clone: $\mathrm{CH}-14$

Uncultured bacterium clone 21BSF7

Uncultured Acidobacteria bacterium clone LF048

Uncultured Acidobacteria bacterium clone LF048

Uncultured Acidobacteria bacterium
Uncultured bacterium clone CCM3

Uncultured Acidobacteria bacterium clone LF013
Uncultured Acidobacteria bacterium clone LF008

Uncultured Acidobacteria bacterium clone LF008

clone T10.0065 Uncultured bacterium clone i10

Uncultured Acidobacteria bacterium clone: LH-54 Uncultured bacterium clone i10

Uncultured bacterium clone ORS40C h05

Uncultured bacterium clone ORS40C_h05

Uncultured bacterium clone Elev_16S_1498

Uncultured bacterium clone $\overline{E S} 3-\overline{4} 7$

Uncultured bacterium clone: N-C-227
Uncultured bacterium clone Elev $16 \mathrm{~S}$ 1498

Uncultured soil bacterium clone L1A.7 $\mathrm{G} 10$

Uncultured bacterium clone Amb_16S_1107

Uncultured soil bacterium clone L1A.7G10
ncultured Acidobacteria bacterium clone BGA.002 de bacteriana em solos de pastagem e agricultura- Piedmont EUA - Jangid,K. et al.,2006

Comunidade bacteriana de solos-Graff,A. and Conrad,R., 2005

Estudo de comunidade microbiana-Tringe,S.G. et al., 2005

Diversidade em mina contaminada com metal pesado-Nemergut,D.R., 2004

Diversidade bacteriana - solo contaminado Hg (EUA)-Oregaard,G. et al., 2007

Diversidade bacteriana solo - Aspen-Lesaulnier,C.C. et al., 2007

Divesidade bacteriana solo - Aspen-Lesalice,C.C. et al., 2007

Diversidade

Diversidade bacteriana solo - Aspen-Lesaulnier,C.C. et al., 2007

Comunidades bacterianas em solos de floresta e agricultura-Upchurch,R. et al., 2006 edimentos subsuperficiais contaminados urânio - Barns,S.M. et al., 2007 Diversidade bacteriana solo - Aspen-Lesaulnier,C.C. et al., 2007

Diversidade bacteriana em solos de pastagem e agricultura- Piedmont EUA - Jangid,K. et al.,2006

Sedimentos subsuperficiais contaminados urânio - Barns,S.M. et al., 2007
Sal., Diversidade bacteriana solo - Aspen-Lesaulnier,C.C. et al., 2007

Comunidade microbiana de sedimentos de rio -Zhao,Y.-G. et al., 2006 Comunidade microbiana de sedimentos de rio-Zhao,Y.-G. et al., 2006

Diversidade bacteriana em solos de pastagem e agricultura- Piedmont EUA - Jangid,K. et al.,2006 Sedimentos subsuperficiais contaminados urânio-Barns,S.M. et al., 2007 Estudo de comunidade microbiana-Tringe,S.G. et al., 2005

Microrganismos de sedimentos do Rio Ohio -D'Angelo,E.M. and Nunez,A.E., 2007

Diversidade de Actinobacteria em solo da Austrália-Holmes,A.J. et al., 2004

Microrganismos em solos de arroz-Hori,T. et aol, 2007

Comunidade bacteriana de solos-Graff,A. and Conrad,R., 2005 Acidobacterias - Zhou,J.P. et al., 2007 Acidobacterias - Zhou,J.P. et al., 2007

Bactérias da caverna Mammoth - Fowler,R. et al., 2003 Acidobacterias - Zhou,J.P. et al., 2007
Acidobacterias - Zhou,J.P. et al., 2007

Sedimentos subsuperficiais contaminados urânio- Barns,S.M. et al., 2007

Sedimentos subsuperficiais contaminados urânio- Barns,S.M. et al., 2007

Diversidade bacteriana de solo-Huang,T. et al., 2006

Microrganismos do solo - Hori,T. et al., 2007

Diversidade bacterana de solo-Huang,T. et al., 2006

Microrganismos de sedimentos do Rio Ohio -D'Angelo,E.M. and Nunez,A.E., 2007

Diversidade bacteriana solo - Aspen-Lesaulnier,C.C. et al., 2007

Comunidade microbiana de sedimentos de rio -Zhao,Y.-G. et al., 2006 Comunidade microbiana de solos-Suzuki,C. et al., 2005

Diversidade bacteriana solo - Aspen-Lesaulnier,C.C. et al., 2007 Bacteria de solo-Schloss,P.D. and Handelsman,J., 2005

Diversidade bacteriana solo - Aspen-Lesaulnier,C.C. et al., 2007 Bacteria de solo-Schloss,P.D. and Handelsman,J., 2005

Sedimentos subsuperficiais contaminados urânio-Barns,S.M. et al., 2007 
Anexo A - Resultados das comparações das seqüências parciais da região 16S rRNA obtidas em amostras de solo Terra Preta Antropogênica e respectivos solos adjacentes da região Amazônica, com as amostras depositadas no GeneBank utilizando o programa Blast

(continuação)

\begin{tabular}{|c|c|c|c|}
\hline Filotipo/Clone & ID \% & No. acesso & pb \\
\hline 83-MITPA3E06 & 98 & EF455262 & 527 \\
\hline 84-MITPA1A09 & 97 & EF019176 & 529 \\
\hline 85-MITPA3D10 & 97 & DQ404693 & 612 \\
\hline 86-MITPA1D08 & 99 & DQ404693 & 553 \\
\hline 87-МITPA3С10 & 99 & EF455264 & 622 \\
\hline 88-MITPA1H09 & 98 & EF457507 & 554 \\
\hline 89-MITPA1H02 & 97 & Z95722 & 673 \\
\hline 90-МITPA1B04 & 96 & AY989267 & 596 \\
\hline 91-MITPA1H01 & 96 & AY988928 & 647 \\
\hline 92-MITPA1E06 & 99 & EF075324 & 512 \\
\hline 93-MITPA1F11 & 96 & DQ128700 & 552 \\
\hline 94-MITPA3B09 & 97 & DQ128349 & 502 \\
\hline 95-MITPA1F05 & 94 & EF127623 & 529 \\
\hline 96-MITPA1F04 & 98 & AY 326530 & 693 \\
\hline 97-MITPA3В06 & 96 & AY 326533 & 607 \\
\hline 98-MITPA1B01 & 96 & EF457383 & 552 \\
\hline 99-MITPA2Е08 & 96 & AY989307 & 560 \\
\hline 100-MITPA2H11 & 98 & EF455453 & 481 \\
\hline 101-MITPA1H10 & 98 & EF455182 & 570 \\
\hline 102-MITPA2C03 & 97 & AY326576 & 585 \\
\hline 103-MITPA2E05 & 98 & EF075168 & 580 \\
\hline 104-MITPA1C09 & 95 & AY493918 & 491 \\
\hline 105-MITPA1G05 & 93 & EF019604 & 582 \\
\hline 106-MITPA3F 12 & 93 & DQ664148 & 539 \\
\hline 107-MITPA3A01 & 99 & EF457395 & 594 \\
\hline 108-MITPA1D09 & 95 & DQ664148 & 485 \\
\hline 109-MITPA2D03 & 97 & EF457474 & 518 \\
\hline 110-MITPA1D04 & 94 & DQ463237 & 645 \\
\hline 111-MITPA2F08 & 95 & EF457307 & 530 \\
\hline 112-MITPA2G07 & 97 & EF516736 & 536 \\
\hline 113-MITPA2H05 & 96 & DQ444068 & 616 \\
\hline 114-MITPA2C07 & 95 & EF073572 & 509 \\
\hline 115-MITPA3B01 & 94 & EF073572 & 519 \\
\hline 116-MITPA2E04 & 91 & EF590003 & 557 \\
\hline 117-MITPA1F08 & 97 & EF515915 & 547 \\
\hline 118-MITPA1A07 & 99 & AY 177763 & 556 \\
\hline 119-MITPA2A02 & 97 & DQ499302 & 532 \\
\hline 120-MITPA2H06 & 98 & AY 960262 & 488 \\
\hline 121-MITPA1D01 & 98 & DQ264442 & 655 \\
\hline 122-MITPA1D07 & 91 & DQ128434 & 529 \\
\hline 123-MITPA1H06 & 89 & DQ128434 & 541 \\
\hline 124-MITPA3C07 & 98 & AY326522 & 448 \\
\hline 125-MITPA1E08 & 97 & EF032778 & 637 \\
\hline 126-MITPA2G09 & 98 & AY493917 & 518 \\
\hline 127-MITPA2D02 & 96 & DQ499326 & 573 \\
\hline 128-MITPA2G11 & 98 & EF072730 & 549 \\
\hline 129-MITPA3H07 & 93 & DQ827812 & 503 \\
\hline 130-MITPA1E01 & 96 & DQ827812 & 492 \\
\hline
\end{tabular}

Organismo

mbiente - Autor

Uncultured soil bacterium clone D23-Fw

Uncultured bacterium clone 655906

Uncultured bacterium clone 655906

Uncultured soil bacterium clone D25-Fw

Uncultured Acidobacteria bacterium clone RP7.0079 Bacterial species (clone RB41)

Uncultured soil bacterium clone L1A0E10
Uncultured soil bacterium clone L1A.5F06

Uncultured Firmicutes bacterium clone GASP-WC2W3 A03

Uncultured soil bacterium clone HSB NT22_B10

Uncultured soil bacterium clone HSB CT52- $\mathrm{G} 01$

Uncultured organism clone DLE128

Uncultured soil bacterium clone 7-1
Uncultured soil bacterium clone 1267-1

Uncultured Acidobacteria bacterium clone BGA.0058

Uncultured soil bacterium clone L1A1A1 Uncultured soil bacterium clone F52-Fw

Uncultured soil bacterium cl Uncultured soil bacterium clone 894-

Uncultured Acidobacteria bacterium clone GASP-WC2W1_C08 Uncultured soil bacterium clone 199

Uncultured bacterium clone Elev_16S 1129 Uncultured bacterium clone $9 \mathrm{~S} 56$

Uncultured Acidobacteria bacterium clone BGB.0067 Uncultured bacterium clone 9S56

Uncultured Acidobacteria bacterium clone RP16.0040 Uncultured bacterium clone DS3-58

Uncultured Acidobacteria bacterium clone T10.003

Uncultured bacterium clone FCPU539

Uncultured Firmicutes bacterium clone GASP-WB1W1 C05

Uncultured Firmicutes bacterium clone GASP-WB1W1_C05 Uncultured bacterium clone E09 Uncultured bacterium clone FCPS549

Uncultured Gram-positive bacterium isolate 5G01 Uncultured bacterium clone CV53

Uncultured beta proteobacterium clone 894

Uncultured bacterium clone BANW446

Uncultured soil bacterium clone CWT CU01_E02

Uncultured soil bacterium clone CWT CU01 E02 Uncultured soil bacterium clone 27-1

Uncultured candidate division WS3 bacterium clone HAVOmat06

Uncultured soil bacterium clone 439

Uncultured bacterium clone CV106

Uncultured delta proteobacterium clone GASP-WA2S3 C06

Uncultured Acidobacteria bacterium clone DOK_BIODYN_clone096

Uncultured Acidobacteria bacterium clone DOK_BIODYN_clone096
Diversidade bacteriana - solo contaminado Hg (EUA)-Oregaard,G. et al., 2007

Diversidade bacteriana solo - Aspen-Lesaulnier,C.C. et al., 2007

População microbiana de sedimento contaminado-Abulencia,C.B. et al., 2006

População microbiana de sedimento contaminado-Abulencia,C.B. et al, 2006

Diversidade bacteriana - solo contaminado $\mathrm{Hg}$ (EUA)-Oregaard, G. et al, 2007

Sedimentos subsuperficiais contaminados urânio -Barns,S.M. et al., 2007

Bacterias com ampla distrubuição-Ludwig,W. et al., 2006

Bacteria de solo-Schloss,P.D. and Handelsman,J., 2005

Bacteria de solo-Schloss,P.D. and Handelsman,.., 2005

Diversidade bacteriana em solos de pastagem e agricultura- Piedmont EUA - Jangid,K. et al.,2006

Comunidades bacterianas em solos de floresta e agricultura-Upchurch,R. et al., 2006

Comunidades bacterianas em solos de floresta e agricultura-Upchurch,R. et al., 2006 Microrganismos encontrados no gelo-Lee,S. et al., 2007

Terra Preta - Amazônia - Kim,J.-S. et al., 2006

Terra Preta - Amazônia - Kim,J.-S. et al., 2006

Sedimentos subsuperficiais contaminados urânio-Barns,S.M. et al., 2007 Bacteria de solo-Schloss,P.D. and Handelsman,J., 2005

Diversidade bacteriana - solo contaminado Hg (EUA)-Oregaard,G. et al., 2007

Diversidade bacteriana - solo contaminado Hg (EUA)-Oregaard,G. et al., 2007 Terra Preta - Amazônia - Kim,J.-S. et al., 2006

Diversidade bacteriana em solos de pastagem e agricultura- Piedmont EUA - Jangid,K. et al.,2006

Comunidade bacteriana de solo-Kim,J.-S. and Crowley,D.E., 2003

Diversidade bacteriana solo - Aspen-Lesaulnier,C.C. et al., 2007

Comunidade microbiana de sedimentos contamindaos com petróleo -Allen,J.P. et al., 2007

Sedimentos subsuperficiais contaminados urânio-Barns,S.M. et al., 2007

Comunidade microbiana de sedimentos contamindaos com petróleo - Allen,J.P. et al., 2007

Sedimentos subsuperficiais contaminados urânio -Barns,S.M. et al., 2007

Comunidade microbiana de sedimentos de rio-Zhao,Y.-G. et al., 2006

Sedimentos subsuperficiais contaminados urânio-Barns,S.M. et al., 2007

Comunidade microbiana solo da Califórnia-Cruz,K. et al.,2007

Comunidade microbiana de sedimentos de rio-Zhao,Y.-G. et al., 2006

Diversidade bacteriana em solos de pastagem e agricultura- Piedmont EUA - Jangid,K. et al.,2006

Diversidade bacteriana em solos de pastagem e agricultura- Piedmont EUA - Jangid,K. et al.,2006

Diversidade bacteriana em sedimentos contaminados com nitrobenzeno Li,D. et al., 2007

Comunidade microbiana solo da Califórnia-Cruz,K. et al.,2007

Diversidade bacteriana de solo - Califórnia-LaMontagne,M.G. et al., 2003

Diversidade microbiana de solo-Macalady,J.L. et al., 2007

Comunidade microbiana-Gonzalez,J.M. et al., 2006

Diversidade microbiana - DeSantis, T Z Z et al, 2007

Comunidades bacterianas em solos de floresta e agricultura-Upchurch,R. et al., 2006

Comunidades bacterianas em solos de floresta e agricultura-Upchurch,R. et al., 2006 Terra Preta - Amazônia - Kim,J.-S. et al., 2006

Microrganismos de caverna vulcânica-Brown,M.V. et al., 2006

Comunidade bacteriana de solo-Kim,J.-S. and Crowley,D.E., 2003 Diversidade microbiana de solo-Macalady,J.L. et al., 2007

Diversidade bacteriana em solos de pastagem e agricultura- Piedmont EUA - Jangid,K. et al.,2006

Diversidade bacteriana de solo-Hartmann,M. and Widmer,F., 2006

Diversidade bacteriana de solo-Hartmann,M. and Widmer,F., 2006 
Anexo A - Resultados das comparações das seqüências parciais da região 16S rRNA obtidas em amostras de solo Terra Preta Antropogênica e respectivos solos adjacentes da região Amazônica, com as amostras depositadas no GeneBank utilizando o programa Blast

(continuação)

\begin{tabular}{|c|c|c|c|c|}
\hline Filotipo/Clone & ID \% & No. acesso & pb & evalt \\
\hline 131-MITPA3D01 & 82 & AY327189 & 557 & \\
\hline 132-MITPA3B08 & 89 & Y592341 & 543 & 0.0 \\
\hline 133-МITPA3Н02 & 90 & EF019897 & 501 & \\
\hline 134-MITPA3C02 & 82 & BX294875 & 605 & $2 \mathrm{e}-1$ \\
\hline 135-MITPA2E06 & 97 & EF455267 & 538 & \\
\hline 136-MITPA3Е08 & 98 & DQ828622 & 487 & 0.0 \\
\hline 137-MITPA2D12 & 93 & DQ664174 & 577 & \\
\hline 138-MITPA1C01 & 87 & AY191334 & 571 & 0.0 \\
\hline 139-MITPA3F07 & 95 & DQ128703 & 511 & \\
\hline 140-MITPA2A06 & 96 & AJ863208 & 520 & 0. \\
\hline 141-MITPA1E07 & 96 & AJ863368 & 508 & \\
\hline 142-MITPA1G08 & 90 & AY326635 & 538 & 0. \\
\hline 143-MITPA2B10 & 93 & AY988610 & 542 & \\
\hline 144-MITPA2H10 & 92 & EF594058 & 570 & \\
\hline 145-MITPA1D12 & 97 & AY214739 & 608 & \\
\hline 146-MITPA1E02 & 97 & AB271056 & 716 & \\
\hline 147-MITPA3A10 & 99 & AJ863232 & 624 & \\
\hline 01-MIADJ1A01 & 98 & AY963453 & 657 & \\
\hline 02-MIADJ1E06 & 98 & AY963453 & 564 & \\
\hline 03-MIADJ1B09 & 96 & AY326591 & 477 & \\
\hline 04-MIADJ1B06 & 99 & AY326598 & 496 & \\
\hline 05-MIADJ3B05 & 96 & AY917434 & 489 & \\
\hline 06-MIADJ2D02 & 99 & DQ381722 & 462 & \\
\hline 07-MIADJ2F12 & 97 & AY395360 & 563 & 0.0 \\
\hline 08-MIADJ1A04 & 89 & DQ316803 & 576 & \\
\hline 09-MIADJ3C02 & 96 & EF074652 & 554 & 0.0 \\
\hline 10-MIADJ3F 12 & 99 & DQ129164 & 501 & \\
\hline 11-MIADJ1C05 & 99 & DQ128559 & 585 & 0.0 \\
\hline 12-MIADJ2B12 & 96 & AB240329 & 577 & \\
\hline 13-MIADJ2F04 & 98 & AY 154637 & 485 & 0.0 \\
\hline 14-MIADJ2H05 & 97 & EF613819 & 391 & \\
\hline 15-MIADJ2D07 & 92 & EF018562 & 507 & 0.0 \\
\hline 16-MIADJ2C03 & 95 & AY913404 & 502 & \\
\hline 17-MIADJ2G04 & 97 & AF465654 & 409 & 0.0 \\
\hline 18-MIADJ3F03 & 94 & EF588341 & 508 & \\
\hline 19-MIADJ3A11 & 99 & AY963488 & 500 & 0.0 \\
\hline 20-MIADJ3A07 & 98 & AY963488 & 572 & \\
\hline 21-MIADJ2F10 & 98 & DQ829857 & 499 & 0.0 \\
\hline 22-MIADJ3H03 & 98 & EF072968 & 574 & \\
\hline 23-MIADJ1D02 & 96 & EF075243 & 586 & 0.0 \\
\hline 24-MIADJ1H01 & 96 & EF019194 & 547 & \\
\hline 25-MIADJ1D06 & 97 & DQ830713 & 571 & 0.0 \\
\hline 26-MIADJ2B04 & 96 & EF588355 & 494 & \\
\hline 27-MIADJ1G08 & 95 & AY963493 & 551 & 0.0 \\
\hline 28-MIADJ1E02 & 94 & EF515877 & 633 & \\
\hline 29-MIADJ3C08 & 95 & AY 963426 & 534 & 0.0 \\
\hline 30-MIADJ3A08 & 93 & EF516272 & 621 & \\
\hline 31-MIADJ3D10 & 93 & EF074920 & 535 & \\
\hline
\end{tabular}

\section{Organismo}

Ambiente - Autor

Diversidade bacteriana-Elshahed, M.S, et al, 2003

Uncultured bacterium clone Amsterdam-1B-38

Uncultured bacterium clone Elev $16 \mathrm{~S}$

Uncultured bacterium clone 032D01 P BA P3

Uncultured soil bacterium clone $\mathrm{D} 28-\mathrm{Fw}$

Uncultured Nitrospira sp. clone DOK_CONFYM_clone362

Uncultured bacterium clone $9 \mathrm{~S} 89$

Uncultured alpha proteobacterium isolate ODP1176A1H3z 7_B

Uncultured soil bacterium clone HSB NT22_C07

Uncultured bacterium clone 25BSU2

Uncultured bacterium clone 28RHF15

Uncultured soil bacterium clone 1180-1

Uncultured soil bacterium clone L1AA03

Uncultured bacterium clone KIST-JJY026

$$
\text { Paenibacillus panacarvi }
$$

Uncultured bacterium clone 26BSF2

Uncultured bacterium clone BS15

Uncultured bacterium clone BS15 e

Uncultured soil bacterium clone 845-2

Uncultured soil bacterium clone 1251-1

ncultured bacterium clone $1700 \mathrm{a}-41$ Burkholderia sp. IBRC204

Uncultured gamma proteobacterium clone EB1041

Uncultured gamma proteobacterium clone 61-01-00d090

Uncultured proteobacterium clone GASP-WC1W1_D11

Uncultured soil bacterium clone CWT ST02_C10

Uncultured soil bacterium clone HSB NF52_A10

Uncultured bacterium clone: RB307

Uncultured earthworm cast bacterium clone c292 Uncultured bacterium clone GA93

Uncultured Methylocystaceae bacterium clone Amb_16S_826

Uncultured forest soil bacterium clone DUNssu198

Uncultured alpha proteobacterium YNPRH71B

Uncultured Acidobacteria bacterium clone WSD-015 Uncultured bacterium clone BS51 Uncultured bacterium clone BS51

Uncultured bacterium clone AG2_C01

Uncultured Acidobacteria bacterium clone GASP-A2W3 H09

Uncultured Acidobacteria bacterium clone GASP-WC2W2_B02

Uncultured bacterium clone PAS1_C 05

Uncultured Acidobacteria bacterium clone WSD-029

Uncultured bacterium clone BS57

ncultured bacterium clone FCPT602

Uncultured bacterium clone AS63

Uncultured bacterium clone FCPN628

Uncultured Acidobacteria bacterium clone GASP-WC2S1_C08
Comunidades microbianas em lamas vulcanicas marinhas-Heijs,S.K. et al., 2004 Diversidade bacteriana solo - Aspen-Lesaulnier,C.C. et al., 2007 Diversidade microbiana -Chouari,R. et al., 2006

Diversidade bacteriana - solo contaminado Hg (EUA)-Oregaard, G. et al, 2007 Diversidade bacteriana de solo-Hartmann,M. and Widmer,F., 2006

Comunidade microbiana de sedimentos contamindaos com petróleo - Allen,J.P. et al., 2007

Comunidade microbianas de sedimentos-Kormas,K.A. et al., 2003

Comunidades bacterianas em solos de floresta e agricultura-Upchurch,R. et al., 2006 Comunidade bacteriana de solos-Graff,A. and Conrad,R., 2005 Comunidade bacteriana de solos-Graff,A. and Conrad,R., 2005 Terra Preta - Amazônia - Kim,J.-S. et al., 2006

Bacteria de solo-Schloss,P.D. and Handelsman,J., 2005 Amostras ambientais-Park,K.S. et al., 2007

Comunidade bacteriana de solos-Liles,M.R. et al., 2003 Diversidade bacteriana de solos - Im,W. and Lee,S., 2006
Comunidade bacteriana de solos-Graff,A. and Conrad,R., 2005

Comunidades bacterianas em solos de floresta - China -Chan,O.C. et al., 2006

Comunidades bacterianas em solos de floresta - China -Chan,O.C. et al., 2006 Terra Preta - Amazônia - Kim,J.-S. et al., 2006 Terra Preta - Amazônia - Kim,J.-S. et al., 2006

de recentes vulcões Hawai-Gomez-Alvarez,V. and Nuesslein,K., 2005

Bactéria fixadora de $\mathrm{N}$ associada a nódulo de Mimoseae-Patreze,C.M. and Cordeiro,L., 2006 Bactérias de solo -Schoenborn,L. et al., 2004

Comunidade microbiana de sedimentos contaminados com urânio-Akob,D.M. et al., 2006 Diversidade bacteriana em solos de pastagem e agricultura- Piedmont EUA - Jangid,K. et al.,2006

Comunidades bacterianas em solos de floresta-Upchurch,R. et al., 2006

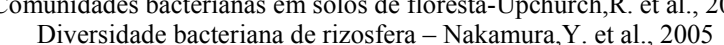

Bacterias intestinais de vermes-Singleton,D.R. et al., 2003

Diversidade bacteriana de várzea de arroz -Kim,M.C. and Ka,J.O., 2007 Diversidade bacteriana solo - Aspen -Lesaulnier.C.C. et al, 2007

Diversidade bacteriana solo de floresta - Alemanha -Roesch,C. et al.,2005

Comunidade microbiana de solo em ambientes térmicos-Norris,T.B. et al., 2004 Diversidade de Acidobactéria-Cho,J.-C. and Lee,S.-H., 2007

Comunidades bacterianas em solos de floresta - China -Chan,O.C. et al., 2006

Comunidades bacterianas em solos de floresta - China-Chan,O.C. et al., 2006 Comunidades bacterianas em solos arroz-Upchurch,R. et al., 2006

Diversidade bacteriana em solos de pastagem e agricultura- Piedmont EUA - Jangid,K. et al.,2006

Diversidade bacteriana em solos de pastagem e agricultura- Piedmont EUA - Jangid,K. et al.,2006 Diversidade bacteriana solo - Aspen -Lesaulnier,C.C. et al., 2007

Comunidades bacterianas em solos arroz-Upchurch,R. et al., 2006

Diversidade de Acidobactéria-Cho,J.-C. and Lee,S.-H., 2007

Comunidades bacterianas em solos de floresta - China -Chan,O.C. et al., 2006 Comunidade microbiana solo da Califórnia-Cruz,K. et al.,2007

Comunidades bacterianas em solos de floresta - China -Chan,O.C. et al., 2006 Comunidade microbiana solo da Califórnia-Cruz,K. et al.,2007 
Anexo A - Resultados das comparações das seqüências parciais da região 16S rRNA obtidas em amostras de solo Terra Preta Antropogênica e respectivos solos adjacentes da região Amazônica, com as amostras depositadas no GeneBank utilizando o programa Blast

(continuação)

\begin{tabular}{|c|c|c|c|}
\hline Filotipo/Clone & ID \% & No. acesso & pb \\
\hline 32-MIADJ3A02 & 94 & AY963515 & 634 \\
\hline 33-MIADJ1B01 & 96 & AY963480 & 530 \\
\hline 34-MIADJ1G05 & 98 & EF393004 & 414 \\
\hline 35-MIADJ1B03 & 97 & EF074319 & 439 \\
\hline 36-MIADJ2B05 & 95 & EF075462 & 499 \\
\hline 37-MIADJ2A06 & 95 & AY963493 & 557 \\
\hline 38-MIADJ2C08 & 96 & EF516244 & 528 \\
\hline 39-MIADJ2B08 & 98 & EF457391 & 528 \\
\hline 40-MIADJ3E01 & 97 & EF457391 & 598 \\
\hline 41-MIADJ2C12 & 95 & EF457391 & 545 \\
\hline 42-MIADJ3D12 & 94 & EF457391 & 574 \\
\hline 43-MIADJ2F11 & 86 & EF516697 & 516 \\
\hline 44-MIADJ2F07 & 98 & EF075896 & 469 \\
\hline 45-MIADJ3E09 & 97 & EF073506 & 524 \\
\hline 46-MIADJ3B10 & 98 & EF075558 & 536 \\
\hline 47-MIADJ2D08 & 98 & EF455194 & 548 \\
\hline 48-MIADJ3E10 & 98 & EF074633 & 502 \\
\hline 49-MIADJ3B06 & 97 & EF516748 & 506 \\
\hline 50-MIADJ3D09 & 98 & EF073569 & 476 \\
\hline 51-MIADJ2G03 & 87 & AY694612 & 571 \\
\hline 52-MIADJ3G01 & 98 & EF516304 & 581 \\
\hline 53-MIADJ1A12 & 97 & EF515903 & 577 \\
\hline 54-MIADJ1D05 & 99 & AY 963452 & 555 \\
\hline 55-MIADJ2D11 & 97 & AY326548 & 445 \\
\hline 56-MIADJ2D09 & 97 & AJ536863 & 532 \\
\hline 57-MIADJ3H01 & 97 & DQ017939 & 572 \\
\hline 58-MIADJ1C02 & 97 & DQ830299 & 670 \\
\hline 59-MIADJ2E04 & 96 & EF588357 & 523 \\
\hline 60-MIADJ2A08 & 95 & EF018429 & 676 \\
\hline 61-MIADJ2G05 & 97 & AJ252655 & 432 \\
\hline 62-MIADJ1D12 & 96 & EF074978 & 617 \\
\hline 63-MIADJ3E04 & 97 & EF614073 & 526 \\
\hline 64-MIADJ2A10 & 93 & DQ509357 & 636 \\
\hline 65-MIADJ3C04 & 92 & AJ519370 & 448 \\
\hline 66-MIADJ1H02 & 93 & AB254785 & 615 \\
\hline 67-MIADJ3G10 & 93 & AF432843 & 450 \\
\hline 68-MIADJ3C01 & 95 & EF074473 & 566 \\
\hline 69-MIADJ2D10 & 99 & AY373357 & 581 \\
\hline 70-MIADJ3B12 & 98 & EF457341 & 510 \\
\hline 71-MIADJ1A06 & 96 & EF516723 & 471 \\
\hline 72-MIADJ3F06 & 98 & DQ128991 & 529 \\
\hline 73-MIADJ3A05 & 96 & AF 145843 & 547 \\
\hline 74-MIADJ3D08 & 99 & EF516886 & 514 \\
\hline 75-MIADJ3G04 & 98 & EF074625 & 420 \\
\hline 76-MIADJ3C12 & 94 & EF613988 & 566 \\
\hline 77-MIADJ3G03 & 97 & EF075598 & 574 \\
\hline 78-MIADJ1H03 & 99 & EF073454 & 528 \\
\hline 79-MIADJ1H11 & 90 & EF515913 & 532 \\
\hline
\end{tabular}

Organismo

Comunidades bacterianas em solos de floresta - China -Chan,O.C. et al., 2006

Uncultured bacterium clone BS79

Uncultured bacterium clone ORS25C g04

Uncultured Acidobacteria bacterium clone GASP-WB2W3_E03

Uncultured Acidobacteria bacterium clone GASP-WDOS1 E01 Uncultured bacterium clone BS57 Uncultured bacterium clone FCPN690

Uncultured Acidobacteria bacterium clone BGB.0024

Uncultured Acidobacteria bacterium clone BGB.0024

Uncultured Acidobacteria bacterium clone BGB.0024

Uncultured Acidobacteria bacterium clone BGB.0024 Uncultured bacterium clone FCPN566

Uncultured Acidobacteriales bacterium clone GASP-WDOW3 D06

Uncultured Acidobacteria bacterium clone GASP-WB1S3_D04

Uncultured Acidobacteria bacterium clone GASP-WDOS2 E04 Uncultured soil bacterium clone $\mathrm{C} 53-\mathrm{Fw}$

Uncultured Acidobacteria bacterium clone GASP-WC1W1_B10 Uncultured bacterium clone FCPN741

Uncultured Firmicutes bacterium clone GASP-WB1W1_C02 Uncultured Holophaga sp. clone JAB SMS 91 Uncultured bacterium clone FCPT68 Uncultured bacterium clone FCPT437 Uncultured bacterium clone BS14 Uncultured soil bacterium clone $157-2$ Uncultured Holophaga sp. clone JG30-KF-C5 Uncultured bacterium clone S-Jos_51 Uncultured bacterium clone CON4 D04

Uncultured Acidobacteria bacterium clone WSD-031

Uncultured bacterium clone Amb_16S_1048 Agricultural soil bacterium clone SC-I-77

Uncultured Firmicutes bacterium clone GASP-WC2S2 B11 Uncultured bacterium clone NGD51

Uncultured bacterium cloneToolik_Aug2004_Shrub_Organic_78

Uncultured Holophaga sp. clone JG37-AG-40

Uncultured bacterium clone: TakashiA-B36 Uncultured bacterium clone S54.21PG

Uncultured Acidobacteria bacterium clone GASP-WC1S2 C01 Bacillus mycoides strain c2 Length $=1506$

Uncultured Acidobacteria bacterium clone D13.0060 Uncultured bacterium clone FCPP515

Uncultured soil bacterium clone HSB OF53_G07 Metal-contaminated soil clone K20-48

Uncultured Acidobacteria bacterium clone GASP-WC1W1_B01 Uncultured bacterium clone NGA66

Uncultured Firmicutes bacterium clone GASP-WDOS3_H10

Uncultured Firmicutes bacterium clone GASP-WB1S3_G08 Uncultured bacterium clone FCPP604
Comunidades bacterianas em solos de floresta - China -Chan,O.C. et al., 2006
Microrganismos de sedimentos do Rio Ohio -D'Angelo,E.M. and Nunez,A.E., 2007

Diversidade bacteriana em solos de pastagem e agricultura- Piedmont EUA - Jangid,K. et al.,2006

Diversidade bacteriana em solos de pastagem e agricultura- Piedmont EUA - Jangid, K. et al .,2006

Comunidades bacterianas em solos de floresta - China -Chan,O.C. et al., 2006 Comunidade microbiana solo da Califórnia-Cruz,K. et al.,2007

Sedimentos subsuperficiais contaminados urânio-Barns,S.M. et al., 2007

Sedimentos subsuperficiais contaminados urânio-Barns,S.M. et al., 2007

Sedimentos subsuperficiais contaminados urânio-Barns,S.M. et al., 2007

Sedimentos subsuperficiais contaminados urânio-Barns,S.M. et al., 2007

Comunidades bacterianas em solos de floresta - China -Chan,O.C. et al., 2006

Diversidade bacteriana em solos de pastagem e agricultura- Piedmont EUA - Jangid,K. et al.,2006 Diversidade bacteriana em solos de pastagem e agricultura- Piedmont EUA - Jangid,K. et al.,2006

Diversidade bacteriana - solo contaminado Hg (EUA)-Oregaard,G. et al., 2007

Diversidade bacteriana em solos de pastagem e agricultura- Piedmont EUA - Jangid,K. et al.,2006 Comunidade microbiana solo da Califórnia-Cruz,K. et al.,2007

- Jangid,K. et al.,2006 Comunidades bacterianas em solos-Val-Moraes,S.P. et al., 2005 Comunidade microbiana solo da Califórnia-Cruz,K. et al.,2007 Comunidade microbiana solo da Califórnia-Cruz,K. et al.,2007

Comunidades bacterianas em solos de floresta - China -Chan,O.C. et al., 2006 Terra Preta - Amazônia - Kim,J.-S. et al., 2006

Diversidade bacteriana de solo - Satchanska,G. et al., 2003

Comunidade bacteriana de água da Europa-Beier,S. et al., 2005

Comunidades bacterianas em solos arroz-Upchurch,R. et al., 2006

Diversidade de Acidobactéria-Cho,J.-C. and Lee,S.-H., 2007

Diversidade bacteriana solo - Aspen -Lesaulnier,C.C. et al., 2007 Bacteria de solo agricola -Lukow,T., 2000

Diversidade bacteriana em solos de pastagem e agricultura- Piedmont EUA - Jangid,K. et al.,2006

Diversidade bacteriana de várzea de arroz-Kim,M.C. and Ka,J.O., 2007

Comunidade bacteriana e fungica no Ártico -Wallenstein,M.D. et al., 2007 Diversidade bacteriana-Geissler,A., 2002 Bacterias de sedimentos-Yoshida,H. et al., 2006

Bacteria - Harris,J.K. et al., 2004
Diversidade bacteriana em solos de pastagem e agricultura- Piedmont EUA - Jangid,K. et al.,2006 Identificação de Bacilus-Ding,Y. and Chen,S., 2003

Sedimentos subsuperficiais contaminados urânio-Barns,S.M. et al., 2007

Comunidade microbiana solo da Califórnia-Cruz,K. et al.,2007

Comunidades bacterianas em solos de floresta e agricultura-Upchurch,R. et al., 2006 Diversidade bacteriana em solos contaminadods com metal-Marsh,T.L. et al., 2004 Comunidade microbiana solo da Califórnia-Cruz,K. et al.,2007

iversidade bacteriana em solos de pastagem e agricultura- Piedmont EUA - Jangid,K. et al.,2006

Diversidade bacteriana de várzea de arroz -Kim,M.C. and Ka,J.O., 2007

Diversidade bacteriana em solos de pastagem e agricultura- Piedmont EUA - Jangid,K. et al.,2006
Diversidade bacteriana em solos de pastagem e agricultura- Piedmont EUA - Jangid,K. et al.,2006 Comunidade microbiana solo da Califórnia-Cruz,K. et al.,2007 
Anexo A - Resultados das comparações das seqüências parciais da região 16S rRNA obtidas em amostras de solo Terra Preta Antropogênica e respectivos solos adjacentes da região Amazônica, com as amostras depositadas no GeneBank utilizando o programa Blast

(continuação)

\begin{tabular}{|c|c|c|c|}
\hline Filotipo/Clone & ID \% & No. acesso & pb \\
\hline 80-MIADJ3E02 & 97 & EF455177 & 487 \\
\hline 81-MIADJ3A09 & 98 & AY963514 & 557 \\
\hline 82-MIADJ2B03 & 93 & EF457402 & 410 \\
\hline 83-MIADJ2D05 & 94 & DQ129081 & 454 \\
\hline 84-MIADJ3E05 & 97 & DQ830110 & 478 \\
\hline 85-MIADJ3H06 & 97 & DQ830466 & 614 \\
\hline 86-MIADJ2C01 & 98 & AY922046 & 516 \\
\hline 87-MIADJ2B08 & 98 & EF457391 & 528 \\
\hline 88-MIADJ3A10 & 96 & EF075793 & 562 \\
\hline 89-MIADJ2A02 & 98 & EF516796 & 599 \\
\hline 90-MIADJ3D06 & 97 & EF516715 & 510 \\
\hline 91-MIADJ1E04 & 96 & EF516825 & 588 \\
\hline 92-MIADJ1C08 & 96 & EF075719 & 603 \\
\hline 93-MIADJ1F05 & 94 & AY917466 & 506 \\
\hline 94-MIADJ1G01 & 98 & EF516715 & 518 \\
\hline 95-MIADJ1D09 & 95 & EF588331 & 512 \\
\hline 96-MIADJ1E01 & 95 & AY326554 & 613 \\
\hline 97-MIADJ1C04 & 91 & EF516796 & 659 \\
\hline 98-MIADJ1E03 & 97 & AJ536884 & 610 \\
\hline 99-MIADJ3G11 & 97 & EF075731 & 429 \\
\hline 100-MIADJ3C03 & 94 & AY326552 & 483 \\
\hline 101-MIADJ2H10 & 91 & EF516921 & 638 \\
\hline 102-MIADJ3A12 & 95 & AY326529 & 478 \\
\hline 103-MIADJ3B02 & 97 & AY326529 & 505 \\
\hline 104-MIADJ1F03 & 99 & AY373357 & 550 \\
\hline 105-MIADJ2H04 & 99 & DQ830281 & 457 \\
\hline 106-MIADJ1G11 & 91 & AB089253 & 455 \\
\hline 107-MIADJ2D12 & 98 & AJ863291 & 527 \\
\hline 108-MIADJ3H11 & 97 & EF434351 & 502 \\
\hline 109-MIADJ1H07 & 96 & DQ829260 & 420 \\
\hline 110-MIADJ1E10 & 97 & AY326516 & 613 \\
\hline 111-MIADJ3B09 & 89 & AY917912 & 483 \\
\hline 112-MIADJ2A11 & 96 & DQ154622 & 415 \\
\hline 113-MIADJ1C06 & 95 & EF073331 & 529 \\
\hline 114-MIADJ1E11 & 94 & DQ830404 & 507 \\
\hline 115-MIADJ1A05 & 98 & DQ451477 & 540 \\
\hline 116-MIADJ2E05 & 96 & EF455267 & 467 \\
\hline 117-MIADJ1B04 & 98 & EF075848 & 467 \\
\hline 118-MIADJ1E08 & 96 & EF075661 & 431 \\
\hline 119-MIADJ1F02 & 93 & EF073798 & 592 \\
\hline 120-MIADJ1G02 & 96 & DQ128519 & 569 \\
\hline 121-MIADJ2B11 & 99 & EF417788 & 447 \\
\hline 122-MIADJ1A07 & 96 & EF516930 & 546 \\
\hline 123-MIADJ1H08 & 94 & EF019592 & 452 \\
\hline 124-MIADJ1A03 & 96 & EF614039 & 510 \\
\hline 125 -MIADJ2A 12 & 97 & AY963387 & 517 \\
\hline 126-MIADJ3G08 & 97 & EF019592 & 427 \\
\hline 127-MIADJ2F03 & 94 & AF432716 & 415 \\
\hline
\end{tabular}

Organismo

mbiente - Autor

Uncultured soil bacterium clone C36-F
Uncultured bacterium clone BS78

Uncultured Acidobacteria bacterium clone BGC.0014

Uncultured soil bacterium clone CWT SM02_E08

Uncultured bacterium clone CON2_E05

Uncultured bacterium clone CON6 $\mathrm{B} 09$

Uncultured Acidobacteria bacterium clone AKYG636

Uncultured Acidobacteria bacterium clone BGB.0024
Uncultured Acidobacteria bacterium clone GASP-WDOW2 D10 Uncultured bacterium clone FCPT625 Uncultured bacterium clone FCPT492

Uncultured bacterium clone FCPN424

Uncultured Bacteroidetes bacterium clone GASP-DOW1_C05 Uncultured bacterium clone 1700b-41

Uncultured Acidobacteria bacterium clone WSD-005 Uncultured soil bacterium clone 958-2 Uncultured bacterium clone FCPT625

Uncultured bacterium clone JG30-KF-AS19

Uncultured Acidobacteria bacterium clone GASP-WDOW1_D05 Uncultured soil bacterium clone 821-2 Uncultured bacterium clone FCPN634 Uncultured soil bacterium clone 271-2 Uncultured soil bacterium clone 271-2 Bacillus mycoides strain c2

Uncultured bacterium clone CON1_D11 Paenibacillus sp. St-4

Uncultured bacterium clone 4 RHU 38

Uncultured Clostridiales bacterium clone 1099982248111

Uncultured proteobacterium clone DOK NOFERT_clone304 Uncultured soil bacterium clone 2-1

Uncultured soil bacterium clone RFS-C 309

Uncultured Nitrospira sp. clone GASP-WB1S1_D08

Uncultured bacterium clone CON5_C02

Uncultured Nitrospirae bacterium clone FAC38

Uncultured soil bacterium clone D28-Fw

Uncultured Nitrospira sp. clone GASP-WDOW3_H02

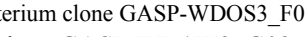

Uncultured soil bacterium clone CWT CU03 F12

Uncultured soil bacterium clone CWT CU03_F
Uncultured actinobacterium clone LF099 Uncultured actinobacterium clone LF099
Uncultured bacterium clone FCPN502

Uncultured bacterium clone FCPN502
Uncultured bacterium clone Elev_16S_1113

Uncultured bacterium clone NGD2

Uncultured bacterium clone AS18

Uncultured bacterium clone Elev_16S_1113 sequence97

Uncultured bacterium clone $\mathrm{C} 17.55 \mathrm{WL}$
Diversidade bacteriana - solo contaminado Hg (EUA)-Oregaard,G. et al., 2007

Comunidades bacterianas em solos de floresta - China -Chan,O.C. et al., 2006

Sedimentos subsuperficiais contaminados urânio-Barns,S.M. et al., 2007

Comunidades bacterianas em solos de floresta-Upchurch,R. et al., 2006
Comunidades bacterianas em solos arroz-Upchurch,R. et al., 2006

Comuris Comunidade microbiana-Tringe,S.G. et al., 2005

Sedimentos subsuperficiais contaminados urânio-Barns,S.M. et al., 2007

Diversidade bacteriana em solos de pastagem e agricultura- Piedmont EUA - Jangid,K. et al.,2006

Comunidade microbiana solo da Califórnia-Cruz,K. et al.,2007

Comunidade microbiana solo da Califórnia-Cruz,K. et al.,2007

Cruz,K. et al.,2007

Diversidade bacteigate agricultura- Piedmont EUA - Jangid,K. et al.,2006

Comunidade microbiana em solos de recentes vulcões Hawai-Gomez-Alvarez,V. and Nuesslein,K., 2005

Comunidade microbiana solo da Califórnia-Cruz,K. et al.,2007

Diversidade de Acidobactéria-Cho,J.-C. and Lee,S.-H., 2007 Terra Preta - Amazônia - Kim,J.-S. et al., 2006

Comunidade microbiana solo da Califórnia-Cruz,K. et al.,2007

Diversidade bacterian de solo - Satchanska,G. et al., 2003

Diversidade bacteriana em solos de pastagem e agricultura- Piedmont EUA - Jangid,K. et al.,2006 Terra Preta - Amazônia - Kim,J.-S. et al., 2006

Comunidade microbiana solo da Califórnia-Cruz,K. et al.,2007 Terra Preta - Amazônia - Kim,J.-S. et al., 2006

Terra Preta - Amazônia - Kim,J.-S. et al., 2006

Bacillus fixadores de nitrogenio-Ding,Y. and Chen,S., 2003

Comunidades bacterianas em solos arroz-Upchurch,R. et al., 2006 Rizosfera de espinafre - Hosoda,A. et al., 2004

Comunidade bacteriana de solos alagados-Graff,A. and Conrad,R., 2005

Microbiota gastrointestinal humana-Palmer,C. et al., 2007

Comunidade bacteriana de solo -Hartmann,M. and Widmer,F., 2006

Terra Preta - Amazônia - Kim,J.-S. et al., 2006
Comunidade microbiana em solos de recentes vulcões Hawai -Gomez-Alvarez,V. and Nuesslein,K., 2005 Bacterias de solo-Becker,J.M. et al., 2005

Diversidade bacteriana em solos de pastagem e agricultura- Piedmont EUA - Jangid,K. et al ,2006

Comunidades bacterianas em solos arroz-Upchurch,R. et al., 2006

Comunidade bacteriana solo de Taiwan-Tsai, $-\mathrm{H}$ et al., 2006

Diversidade bacteriana - solo contaminado Hg (EUA)-Oregaard,G. et al., 2007

Diversidade bacteriana em solos de pastagem e agricultura- Piedmont EUA - Jangid,K. et al.,2006

Diversidade bacteriana em solos de pastagem e agricultura- Piedmont EUA - Jangid,K. et al.,2006

Diversidade bacteriana em solos de pastagem e agricultura- Piedmont EUA - Jangid,K. et al.,2006

Comunidades bacterianas em solos de floresta-Upchurch,R. et al., 2006 Acidobacterias - Zhou,J.P. et al., 2007

Comunidade microbiana solo da Califórnia-Cruz,K. et al.,2007

Diversidade bacteriana solo - Aspen -Lesaulnier,C.C. et al., 2007

Diversidade bacteriana de várzea de arroz -Kim,M.C. and Ka,J.O., 2007

Comunidades bacterianas em solos de floresta - China -Chan,O.C. et al., 2006

Diversidade bacteriana solo - Aspen -Lesaulnier,C.C. et al., 2007

Diversidade bacteriana floresta da Colômbia-Chow,M.L. et al., 2004 
Anexo A - Resultados das comparações das seqüências parciais da região 16S rRNA obtidas em amostras de solo Terra Preta Antropogênica e respectivos solos adjacentes da região Amazônica, com as amostras depositadas no GeneBank utilizando o programa Blast

(conclusão)

\begin{tabular}{|c|c|c|c|c|c|c|}
\hline Filotipo/Clone & ID \% & No. acesso & pb & evalue & Organismo & Ambiente - Autor \\
\hline 128-MIADJ1D04 & 99 & DQ128543 & 501 & 0.0 & Uncultured soil bacterium clone HSB NF51_D05 & Comunidades bacterianas em solos de floresta-Upchurch,R. et al., 2006 \\
\hline 129-MIADJ1H04 & 95 & DQ395984 & 459 & 0.0 & Uncultured organism clone ctg_CGOGĀ̄ 2 & Penn,K. et al., 2006 \\
\hline 130-MIADJ1H05 & 96 & EF516621 & 439 & 0.0 & Uncultured bacterium clone FCPU392 & Comunidade microbiana solo da Califórnia-Cruz,K. et al.,2007 \\
\hline 131-MIADJ1A08 & 97 & EF516594 & 587 & 0.0 & Uncultured bacterium clone FCPO730 & Comunidade microbiana solo da Califórnia-Cruz,K. et al.,2007 \\
\hline 132-MIADJ1B11 & 96 & EF494340 & 448 & 0.0 & Uncultured bacterium clone NR.035 & Diversidade microbiana de solo - Macalady,J.L. et al., 2007 \\
\hline 133-MIADJ1D11 & 98 & DQ128684 & 442 & 0.0 & Uncultured soil bacterium clone HSB NT21_F11RU & Comunidades bacterianas em solos de floresta-Upchurch,R. et al., 2006 \\
\hline 134-MIADJ1E09 & 96 & EF516526 & 523 & 0.0 & Uncultured bacterium clone FCPP $42 \overline{8}$ & Comunidade microbiana solo da Califórnia-Cruz,K. et al.,2007 \\
\hline 135-MIADJ2A01 & 98 & DQ663840 & 518 & 0.0 & Uncultured bacterium clone $5 \mathrm{~V} 63$ & Comunidades microbianas-sedimentos contaminados petróleo-Allen,J.P. et al., 2007 \\
\hline 136-MIADJ2B02 & 96 & DQ154536 & 482 & 0.0 & Uncultured soil bacterium clone RFS-C220 & Bacteria de solo -Becker,J.M. et al., 2005 \\
\hline 137-MIADJ2C10 & 94 & AY913709 & 503 & 0.0 & Uncultured forest soil bacterium clone DUNssu624 & Diversidade bacteriana solo de floresta - Alemanha -Roesch,C. et al.,2005 \\
\hline 138-MIADJ2E01 & 98 & EF018425 & 403 & 0.0 & Uncultured bacterium clone Amb_16S_1044 & Diversidade bacteriana solo - Aspen -Lesaulnier,C.C. et al., 2007 \\
\hline 139-MIADJ3D03 & 96 & EF516854 & 482 & 0.0 & Uncultured bacterium clone FC̄PS $\overline{65} 9$ & Comunidade microbiana solo da Califórnia-Cruz,K. et al.,2007 \\
\hline 140-MIADJ3H02 & 98 & DQ129135 & 554 & 0.0 & Uncultured soil bacterium clone CWT ST01_B02 & Comunidades bacterianas em solos de floresta-Upchurch,R. et al., 2006 \\
\hline 141-MIADJ3B08 & 99 & DQ643749 & 576 & 0.0 & Uncultured soil bacterium clone W4Ba $8 \overline{8}$ & Diversidade microbiana de solo - Lueders,T. et al., 2006 \\
\hline
\end{tabular}

BITPA - Lagoa Balbina Terra Preta Antropogênica; BIADJ - Lagoa Balbina Adjacente; MITPA - Floresta Nacional de Caxiuanã - Mina I Terra Preta Antropogênica; MIADJ -

Número de acesso das seqüências de maior similaridade no banco de dados; pb: Tamanho em pares de base de cada clone; e-value: e-value entre as seqüências estudadas e a de maior similaridade no banco de dados. 
ANEXO B - Resultados das comparações das seqüências parciais da região 16S rRNA obtidas em amostras de solo Terra Preta Antropogênica e respectivos solos adjacentes da região Amazônica Central e Oriental, com as amostras depositadas no banco de dados de seqüências de 16S rRNA do RDP II pelo programa Classifier

(continua)

\begin{tabular}{|c|c|c|c|c|c|c|c|c|c|c|}
\hline Clone & Filo & & Classe & & Ordem & & Familia & & Genero & \\
\hline BITPA1A01 & Proteobacteria & $43 \%$ & Deltaproteobacteria & $39 \%$ & Myxococcales & $36 \%$ & Cystobacterineae & $34 \%$ & Cystobacteraceae & $34 \%$ \\
\hline BITPA1A02 & Firmicutes & $100 \%$ & Bacilli & $100 \%$ & Bacillales & $100 \%$ & Bacillaceae & $99 \%$ & Bacillus & $95 \%$ \\
\hline BITPA1A03 & Proteobacteria & $95 \%$ & Deltaproteobacteria & $95 \%$ & Syntrophobacterales & $52 \%$ & Syntrophaceae & $43 \%$ & Smithella & $40 \%$ \\
\hline BITPA1A04 & Acidobacteria & $83 \%$ & Acidobacteria & $83 \%$ & Acidobacteriales & $83 \%$ & Acidobacteriaceae & $83 \%$ & Acidobacterium & $82 \%$ \\
\hline BITPA1A06 & Firmicutes & $100 \%$ & Bacilli & $100 \%$ & Bacillales & $100 \%$ & Bacillaceae & $100 \%$ & Bacillus & $100 \%$ \\
\hline BITPA1A07 & Acidobacteria & $39 \%$ & Acidobacteria & $39 \%$ & Acidobacteriales & $39 \%$ & Acidobacteriaceae & $39 \%$ & Holophaga & $23 \%$ \\
\hline BITPA1A08 & Firmicutes & $100 \%$ & Bacilli & $100 \%$ & Bacillales & $100 \%$ & Bacillaceae & $100 \%$ & Bacillus & $99 \%$ \\
\hline BITPA1A09 & Firmicutes & $100 \%$ & Bacilli & $100 \%$ & Bacillales & $100 \%$ & Paenibacillaceae & $97 \%$ & Paenibacillus & $97 \%$ \\
\hline BITPA1A12 & Proteobacteria & $100 \%$ & Alphaproteobacteria & $100 \%$ & Rhizobiales & $96 \%$ & Bradyrhizobiaceae & $46 \%$ & Agromonas & $24 \%$ \\
\hline BITPA1B01 & Firmicutes & $100 \%$ & Bacilli & $100 \%$ & Bacillales & $100 \%$ & Planococcaceae & $62 \%$ & Kurthia & $62 \%$ \\
\hline ВITPA1B03 & Nitrospira & $100 \%$ & Nitrospira & $100 \%$ & Nitrospirales & $100 \%$ & Nitrospiraceae & $100 \%$ & Nitrospira & $100 \%$ \\
\hline ВITPA1B04 & Firmicutes & $100 \%$ & Bacilli & $100 \%$ & Bacillales & $100 \%$ & Bacillaceae & $100 \%$ & Bacillus & $97 \%$ \\
\hline BITPA1B05 & Proteobacteria & $35 \%$ & Alphaproteobacteria & $15 \%$ & Rhodospirillales & $14 \%$ & Acetobacteraceae & $11 \%$ & Teichococcus & $4 \%$ \\
\hline BITPA1B07 & Proteobacteria & $100 \%$ & Betaproteobacteria & $96 \%$ & Burkholderiales & $78 \%$ & Incertae sedis 5 & $33 \%$ & Thiobacter & $17 \%$ \\
\hline BITPA1B08 & Acidobacteria & $49 \%$ & Acidobacteria & $49 \%$ & Acidobacteriales & $49 \%$ & Acidobacteriaceae & $49 \%$ & Acidobacterium & $44 \%$ \\
\hline BITPA1B09 & Verrucomicrobia & $99 \%$ & Verrucomicrobiae & $99 \%$ & Verrucomicrobiales & $99 \%$ & Verrucomicrobiaceae & $90 \%$ & Verrucomicrobium & $90 \%$ \\
\hline BITPA1B10 & Firmicutes & $100 \%$ & Bacilli & $100 \%$ & Bacillales & $100 \%$ & Bacillaceae & $100 \%$ & Bacillus & $99 \%$ \\
\hline BITPA1B12 & Firmicutes & $100 \%$ & Bacilli & $100 \%$ & Bacillales & $100 \%$ & Bacillaceae & $100 \%$ & Bacillus & $100 \%$ \\
\hline BITPA1C01 & Firmicutes & $100 \%$ & Bacilli & $100 \%$ & Bacillales & $100 \%$ & Bacillaceae & $100 \%$ & Bacillus & $100 \%$ \\
\hline BITPA1C02 & Firmicutes & $100 \%$ & Bacilli & $100 \%$ & Bacillales & $100 \%$ & Bacillaceae & $100 \%$ & Bacillus & $100 \%$ \\
\hline BITPA1C04 & Firmicutes & $100 \%$ & Bacilli & $100 \%$ & Bacillales & $100 \%$ & Bacillaceae & $100 \%$ & Bacillus & $92 \%$ \\
\hline BITPA1C05 & Proteobacteria & $90 \%$ & Deltaproteobacteria & $65 \%$ & Myxococcales & $34 \%$ & Cystobacterineae & $24 \%$ & Cystobacteraceae & $22 \%$ \\
\hline BITPA1C06 & Firmicutes & $100 \%$ & Bacilli & $100 \%$ & Bacillales & $100 \%$ & Bacillaceae & $100 \%$ & Bacillus & $99 \%$ \\
\hline BITPA1C07 & Firmicutes & $100 \%$ & Bacilli & $100 \%$ & Bacillales & $100 \%$ & Bacillaceae & $99 \%$ & Bacillus & $83 \%$ \\
\hline BITPA1C09 & Firmicutes & $100 \%$ & Bacilli & $100 \%$ & Bacillales & $100 \%$ & Bacillaceae & $100 \%$ & Bacillus & $100 \%$ \\
\hline BITPA1C10 & Firmicutes & $34 \%$ & Clostridia & $33 \%$ & Clostridiales & $33 \%$ & Clostridiaceae & $26 \%$ & Thermobrachium & $12 \%$ \\
\hline BITPA1D01 & Firmicutes & $100 \%$ & Bacilli & $100 \%$ & Bacillales & $99 \%$ & Bacillaceae & $96 \%$ & Bacillus & $91 \%$ \\
\hline
\end{tabular}


ANEXO B - Resultados das comparações das seqüências parciais da região 16S rRNA obtidas em amostras de solo Terra Preta Antropogênica e respectivos solos adjacentes da região Amazônica Central e Oriental, com as amostras depositadas no banco de dados de seqüências de 16S rRNA do RDP II pelo programa Classifier

\begin{tabular}{|c|c|c|c|c|c|c|c|c|c|c|}
\hline Clone & Filo & & Classe & & Ordem & & Familia & & Genero & \\
\hline BITPA1D02 & Firmicutes & $100 \%$ & Bacilli & $100 \%$ & Bacillales & $100 \%$ & Bacillaceae & $99 \%$ & Bacillus & $96 \%$ \\
\hline BITPA1D04 & Firmicutes & $99 \%$ & Bacilli & $77 \%$ & Bacillales & $65 \%$ & Bacillaceae & $31 \%$ & Paraliobacillus & $12 \%$ \\
\hline BITPA1D05 & Verrucomicrobia & $86 \%$ & Verrucomicrobiae & $86 \%$ & Verrucomicrobiales & $86 \%$ & Verrucomicrobiaceae & $62 \%$ & Verrucomicrobium & $62 \%$ \\
\hline BITPA1D06 & Firmicutes & $100 \%$ & Bacilli & $100 \%$ & Bacillales & $100 \%$ & Bacillaceae & $100 \%$ & Bacillus & $100 \%$ \\
\hline BITPA1D07 & Firmicutes & $100 \%$ & Bacilli & $100 \%$ & Bacillales & $100 \%$ & Bacillaceae & $100 \%$ & Bacillus & $99 \%$ \\
\hline BITPA1D08 & Firmicutes & $100 \%$ & Bacilli & $100 \%$ & Bacillales & $100 \%$ & Paenibacillaceae & $98 \%$ & Paenibacillus & $98 \%$ \\
\hline BITPA1D10 & Firmicutes & $100 \%$ & Bacilli & $100 \%$ & Bacillales & $100 \%$ & Bacillaceae & $98 \%$ & Bacillus & $81 \%$ \\
\hline BITPA1D12 & Firmicutes & $100 \%$ & Bacilli & $100 \%$ & Bacillales & $100 \%$ & Bacillaceae & $100 \%$ & Bacillus & $99 \%$ \\
\hline BITPA1E01 & Proteobacteria & $100 \%$ & Alphaproteobacteria & $100 \%$ & Rhizobiales & $100 \%$ & Beijerinckiaceae & $96 \%$ & Methylocapsa & $48 \%$ \\
\hline BITPA1E02 & Firmicutes & $39 \%$ & Clostridia & $29 \%$ & Clostridiales & $23 \%$ & Acidaminococcaceae & $16 \%$ & Papillibacter & $12 \%$ \\
\hline BITPA1E04 & Proteobacteria & $100 \%$ & Alphaproteobacteria & $100 \%$ & Rhizobiales & $91 \%$ & Hyphomicrobiaceae & $55 \%$ & Angulomicrobium & $24 \%$ \\
\hline BITPA1E05 & Proteobacteria & $75 \%$ & Gammaproteobacteria & $29 \%$ & Chromatiales & $12 \%$ & Ectothiorhodospiraceae & $11 \%$ & Nitrococcus & $8 \%$ \\
\hline BITPA1E06 & Firmicutes & $100 \%$ & Bacilli & $100 \%$ & Bacillales & $100 \%$ & Bacillaceae & $100 \%$ & Bacillus & $100 \%$ \\
\hline BITPA1E07 & Proteobacteria & $39 \%$ & Gammaproteobacteria & $13 \%$ & Chromatiales & $7 \%$ & Ectothiorhodospiraceae & $6 \%$ & Thiorhodospira & $6 \%$ \\
\hline BITPA1E09 & Proteobacteria & $95 \%$ & Alphaproteobacteria & $92 \%$ & Rhizobiales & $57 \%$ & Hyphomicrobiaceae & $37 \%$ & Labrys & $35 \%$ \\
\hline BITPA1E10 & Firmicutes & $100 \%$ & Bacilli & $100 \%$ & Bacillales & $100 \%$ & Bacillaceae & $100 \%$ & Bacillus & $100 \%$ \\
\hline BITPA1E12 & Proteobacteria & $99 \%$ & Deltaproteobacteria & $96 \%$ & Syntrophobacterales & $45 \%$ & Syntrophaceae & $33 \%$ & Smithella & $30 \%$ \\
\hline BITPA1F01 & Firmicutes & $100 \%$ & Bacilli & $100 \%$ & Bacillales & $100 \%$ & Bacillaceae & $99 \%$ & Bacillus & $95 \%$ \\
\hline BITPA1F02 & Acidobacteria & $97 \%$ & Acidobacteria & $97 \%$ & Acidobacteriales & $97 \%$ & Acidobacteriaceae & $97 \%$ & Acidobacterium & $97 \%$ \\
\hline BITPA1F04 & Proteobacteria & $100 \%$ & Alphaproteobacteria & $100 \%$ & Rhizobiales & $100 \%$ & Hyphomicrobiaceae & $68 \%$ & Rhodoplanes & $57 \%$ \\
\hline BITPA1F05 & Firmicutes & $63 \%$ & Bacilli & $54 \%$ & Bacillales & $54 \%$ & Bacillaceae & $52 \%$ & Paraliobacillus & $32 \%$ \\
\hline BITPA1F06 & Firmicutes & $100 \%$ & Bacilli & $100 \%$ & Bacillales & $100 \%$ & Paenibacillaceae & $100 \%$ & Paenibacillus & $100 \%$ \\
\hline BITPA1F07 & Verrucomicrobia & $100 \%$ & Verrucomicrobiae & $100 \%$ & Verrucomicrobiales & $100 \%$ & Verrucomicrobiaceae & $57 \%$ & Verrucomicrobium & $57 \%$ \\
\hline BITPA1F09 & Proteobacteria & $44 \%$ & Alphaproteobacteria & $22 \%$ & Rhodospirillales & $8 \%$ & Acetobacteraceae & $6 \%$ & Roseococcus & $4 \%$ \\
\hline BITPA1F 10 & Firmicutes & $100 \%$ & Bacilli & $100 \%$ & Bacillales & $100 \%$ & Bacillaceae & $98 \%$ & Bacillus & $95 \%$ \\
\hline BITPA1G01 & Verrucomicrobia & $49 \%$ & Verrucomicrobiae & $49 \%$ & Verrucomicrobiales & $49 \%$ & Verrucomicrobiaceae & $45 \%$ & Verrucomicrobium & $45 \%$ \\
\hline BITPA1G02 & Firmicutes & $100 \%$ & Bacilli & $99 \%$ & Bacillales & $99 \%$ & Paenibacillaceae & $96 \%$ & Paenibacillus & $85 \%$ \\
\hline BITPA1G04 & Proteobacteria & $25 \%$ & Deltaproteobacteria & $9 \%$ & Desulfuromonales & $5 \%$ & Desulfuromonaceae & $5 \%$ & Malonomonas & $5 \%$ \\
\hline BITPA1G05 & Firmicutes & $100 \%$ & Bacilli & $100 \%$ & Bacillales & $100 \%$ & Bacillaceae & $100 \%$ & Bacillus & $100 \%$ \\
\hline BITPA1G06 & Firmicutes & $100 \%$ & Bacilli & $100 \%$ & Bacillales & $100 \%$ & Bacillaceae & $100 \%$ & Bacillus & $99 \%$ \\
\hline BITPA1G07 & Actinobacteria & $76 \%$ & Actinobacteria & $76 \%$ & Actinobacteridae & $76 \%$ & Actinomycetales & $76 \%$ & Streptomycineae & $72 \%$ \\
\hline BITPA1G10 & Firmicutes & $100 \%$ & Bacilli & $100 \%$ & Bacillales & $100 \%$ & Bacillaceae & $100 \%$ & Bacillus & $91 \%$ \\
\hline BITPA1H05 & Thermomicrobia & $55 \%$ & Thermomicrobia & $55 \%$ & Thermomicrobiales & $55 \%$ & Thermomicrobiaceae & $55 \%$ & Thermomicrobium & $55 \%$ \\
\hline BITPA1H08 & Firmicutes & $100 \%$ & Bacilli & $100 \%$ & Bacillales & $100 \%$ & Bacillaceae & $92 \%$ & Bacillus & $64 \%$ \\
\hline
\end{tabular}


ANEXO B - Resultados das comparações das seqüências parciais da região 16S rRNA obtidas em amostras de solo Terra Preta Antropogênica e respectivos solos adjacentes da região Amazônica Central e Oriental, com as amostras depositadas no banco de dados de seqüências de 16S rRNA do RDP II pelo programa Classifier

\begin{tabular}{|c|c|c|c|c|c|c|c|c|c|c|}
\hline Clone & Filo & & Classe & & Ordem & & Familia & & Genero & \\
\hline BITPA2A02 & Proteobacteria & $44 \%$ & Gammaproteobacteria & $31 \%$ & Xanthomonadales & $26 \%$ & Xanthomonadaceae & $26 \%$ & Hydrocarboniphaga & $17 \%$ \\
\hline BITPA2A03 & Firmicutes & $90 \%$ & Bacilli & $82 \%$ & Bacillales & $82 \%$ & Bacillaceae & $82 \%$ & Paraliobacillus & $36 \%$ \\
\hline BITPA2A04 & Actinobacteria & $100 \%$ & Actinobacteria & $100 \%$ & Actinobacteridae & $100 \%$ & Actinomycetales & $100 \%$ & Streptomycineae & $100 \%$ \\
\hline BITPA2A05 & Firmicutes & $43 \%$ & Clostridia & $43 \%$ & Clostridiales & $42 \%$ & Peptococcaceae & $20 \%$ & Pelotomaculum & $19 \%$ \\
\hline BITPA2A06 & Verrucomicrobia & $53 \%$ & Verrucomicrobiae & $53 \%$ & Verrucomicrobiales & $53 \%$ & Verrucomicrobiaceae & $32 \%$ & Verrucomicrobium & $31 \%$ \\
\hline BITPA2A07 & Proteobacteria & $100 \%$ & Betaproteobacteria & $100 \%$ & Methylophilales & $75 \%$ & Methylophilaceae & $75 \%$ & Methylobacillus & $69 \%$ \\
\hline BITPA2A09 & Proteobacteria & $100 \%$ & Alphaproteobacteria & $100 \%$ & Rhizobiales & $95 \%$ & Methylocystaceae & $44 \%$ & Methylosinus & $28 \%$ \\
\hline BITPA2A 10 & Firmicutes & $100 \%$ & Bacilli & $100 \%$ & Bacillales & $100 \%$ & Bacillaceae & $100 \%$ & Bacillus & $100 \%$ \\
\hline BITPA2A11 & Firmicutes & $100 \%$ & Bacilli & $100 \%$ & Bacillales & $100 \%$ & Bacillaceae & $100 \%$ & Bacillus & $100 \%$ \\
\hline BITPA2A 12 & Gemmatimonadetes & $87 \%$ & Gemmatimonadetes & $87 \%$ & Gemmatimonadales & $87 \%$ & Gemmatimonadaceae & $87 \%$ & Gemmatimonas & $87 \%$ \\
\hline ВITPA2B01 & Gemmatimonadetes & $94 \%$ & Gemmatimonadetes & $94 \%$ & Gemmatimonadales & $94 \%$ & Gemmatimonadaceae & $94 \%$ & Gemmatimonas & $94 \%$ \\
\hline ВITPA2B02 & Thermomicrobia & $48 \%$ & Thermomicrobia & $48 \%$ & Thermomicrobiales & $48 \%$ & Thermomicrobiaceae & $48 \%$ & Thermomicrobium & $48 \%$ \\
\hline ВITPA2B03 & Firmicutes & $100 \%$ & Bacilli & $100 \%$ & Bacillales & $100 \%$ & Bacillaceae & $99 \%$ & Bacillus & $84 \%$ \\
\hline BITPA2B04 & Proteobacteria & $100 \%$ & Alphaproteobacteria & $100 \%$ & Rhizobiales & $100 \%$ & Hyphomicrobiaceae & $100 \%$ & Pedomicrobium & $97 \%$ \\
\hline BITPA2B05 & Firmicutes & $100 \%$ & Bacilli & $100 \%$ & Bacillales & $100 \%$ & Bacillaceae & $100 \%$ & Bacillus & $100 \%$ \\
\hline BITPA2B06 & Firmicutes & $26 \%$ & Clostridia & $26 \%$ & Thermoanaerobacteriales & $24 \%$ & Thermodesulfobiaceae & $22 \%$ & Thermodesulfobium & $22 \%$ \\
\hline BITPA2B07 & Proteobacteria & $46 \%$ & Deltaproteobacteria & $29 \%$ & Myxococcales & $14 \%$ & Cystobacterineae & $14 \%$ & Myxococcaceae & $11 \%$ \\
\hline BITPA2B08 & Firmicutes & $100 \%$ & Bacilli & $100 \%$ & Bacillales & $100 \%$ & Bacillaceae & $96 \%$ & Bacillus & $93 \%$ \\
\hline BITPA2B10 & Verrucomicrobia & $87 \%$ & Verrucomicrobiae & $87 \%$ & Verrucomicrobiales & $87 \%$ & Xiphinematobacteriaceae & $54 \%$ & Xiphinematobacter & $54 \%$ \\
\hline BITPA2B11 & Proteobacteria & $47 \%$ & Deltaproteobacteria & $22 \%$ & Myxococcales & $10 \%$ & Cystobacterineae & $9 \%$ & Cystobacteraceae & $9 \%$ \\
\hline BITPA2B12 & Firmicutes & $100 \%$ & Bacilli & $100 \%$ & Bacillales & $100 \%$ & Bacillaceae & $100 \%$ & Bacillus & $96 \%$ \\
\hline BITPA2C01 & Nitrospira & $52 \%$ & Nitrospira & $52 \%$ & Nitrospirales & $52 \%$ & Nitrospiraceae & $52 \%$ & Nitrospira & $52 \%$ \\
\hline BITPA2C02 & Lentisphaerae & $39 \%$ & Lentisphaerae & $39 \%$ & Victivallales & $25 \%$ & Victivallaceae & $25 \%$ & Victivallis & $25 \%$ \\
\hline BITPA2C03 & Firmicutes & $32 \%$ & Bacilli & $20 \%$ & Bacillales & $20 \%$ & Bacillaceae & $11 \%$ & Saccharococcus & $6 \%$ \\
\hline BITPA2C04 & Firmicutes & $100 \%$ & Bacilli & $100 \%$ & Bacillales & $100 \%$ & Bacillaceae & $98 \%$ & Bacillus & $82 \%$ \\
\hline BITPA2C09 & Thermomicrobia & $47 \%$ & Thermomicrobia & $47 \%$ & Thermomicrobiales & $47 \%$ & Thermomicrobiaceae & $47 \%$ & Thermomicrobium & $47 \%$ \\
\hline BITPA2C12 & Firmicutes & $100 \%$ & Bacilli & $100 \%$ & Bacillales & $100 \%$ & Bacillaceae & $100 \%$ & Bacillus & $100 \%$ \\
\hline BITPA2D01 & Firmicutes & $100 \%$ & Bacilli & $100 \%$ & Bacillales & $100 \%$ & Bacillaceae & $96 \%$ & Bacillus & $93 \%$ \\
\hline BITPA2D02 & Verrucomicrobia & $99 \%$ & Verrucomicrobiae & $99 \%$ & Verrucomicrobiales & $99 \%$ & Verrucomicrobiaceae & $79 \%$ & Verrucomicrobium & $79 \%$ \\
\hline BITPA2D03 & Firmicutes & $24 \%$ & Clostridia & $24 \%$ & Thermoanaerobacteriales & $22 \%$ & Thermodesulfobiaceae & $22 \%$ & Thermodesulfobium & $22 \%$ \\
\hline BITPA2D04 & Firmicutes & $100 \%$ & Bacilli & $100 \%$ & Bacillales & $100 \%$ & Bacillaceae & $100 \%$ & Bacillus & $100 \%$ \\
\hline BITPA2D09 & Firmicutes & $100 \%$ & Bacilli & $100 \%$ & Bacillales & $95 \%$ & Bacillaceae & $86 \%$ & Paraliobacillus & $49 \%$ \\
\hline BITPA2E01 & Proteobacteria & $41 \%$ & Deltaproteobacteria & $38 \%$ & Myxococcales & $36 \%$ & Cystobacterineae & $34 \%$ & Cystobacteraceae & $34 \%$ \\
\hline BITPA2E02 & Firmicutes & $100 \%$ & Bacilli & $100 \%$ & Bacillales & $100 \%$ & Bacillaceae & $100 \%$ & Bacillus & $99 \%$ \\
\hline
\end{tabular}


ANEXO B - Resultados das comparações das seqüências parciais da região 16S rRNA obtidas em amostras de solo Terra Preta Antropogênica e respectivos solos adjacentes da região Amazônica Central e Oriental, com as amostras depositadas no banco de dados de seqüências de 16S rRNA do RDP II pelo programa Classifier

\begin{tabular}{|c|c|c|c|c|c|c|c|c|c|c|}
\hline Clone & Filo & & Classe & & Ordem & & Familia & & Genero & \\
\hline BITPA2Е03 & Proteobacteria & $73 \%$ & Deltaproteobacteria & $59 \%$ & Desulfurellales & $42 \%$ & Desulfurellaceae & $42 \%$ & Hippea & $42 \%$ \\
\hline BITPA2Е04 & Verrucomicrobia & $100 \%$ & Verrucomicrobiae & $100 \%$ & Verrucomicrobiales & $100 \%$ & Xiphinematobacteriaceae & $82 \%$ & Xiphinematobacter & $82 \%$ \\
\hline BITPA2Е09 & Verrucomicrobia & $86 \%$ & Verrucomicrobiae & $86 \%$ & Verrucomicrobiales & $86 \%$ & Verrucomicrobiaceae & $43 \%$ & Verrucomicrobium & $43 \%$ \\
\hline BITPA2E10 & Verrucomicrobia & $94 \%$ & Verrucomicrobiae & $94 \%$ & Verrucomicrobiales & $94 \%$ & Verrucomicrobiaceae & $56 \%$ & Verrucomicrobium & $56 \%$ \\
\hline BITPA2F01 & Firmicutes & $100 \%$ & Bacilli & $100 \%$ & Bacillales & $100 \%$ & Bacillaceae & $100 \%$ & Bacillus & $100 \%$ \\
\hline BITPA2F02 & Gemmatimonadetes & $99 \%$ & Gemmatimonadetes & $99 \%$ & Gemmatimonadales & $99 \%$ & Gemmatimonadaceae & $99 \%$ & Gemmatimonas & $99 \%$ \\
\hline BITPA2F08 & Firmicutes & $100 \%$ & Bacilli & $100 \%$ & Bacillales & $100 \%$ & Bacillaceae & $100 \%$ & Bacillus & $100 \%$ \\
\hline BITPA2G01 & Proteobacteria & $100 \%$ & Alphaproteobacteria & $100 \%$ & Rhizobiales & $93 \%$ & Methylocystaceae & $47 \%$ & Methylocystis & $26 \%$ \\
\hline BITPA2G02 & Proteobacteria & $100 \%$ & Alphaproteobacteria & $100 \%$ & Rhizobiales & $98 \%$ & Hyphomicrobiaceae & $91 \%$ & Blastochloris & $91 \%$ \\
\hline BITPA2G03 & Firmicutes & $40 \%$ & Clostridia & $40 \%$ & Clostridiales & $36 \%$ & Clostridiaceae & $12 \%$ & Faecalibacterium & $7 \%$ \\
\hline ВITPA2H01 & Proteobacteria & $56 \%$ & Deltaproteobacteria & $27 \%$ & Syntrophobacterales & $15 \%$ & Syntrophobacteraceae & $15 \%$ & Desulfovirga & $13 \%$ \\
\hline BITPA2H02 & Firmicutes & $100 \%$ & Bacilli & $100 \%$ & Bacillales & $100 \%$ & Bacillaceae & $100 \%$ & Bacillus & $100 \%$ \\
\hline BITPA2H09 & Firmicutes & $100 \%$ & Bacilli & $100 \%$ & Bacillales & $100 \%$ & Bacillaceae & $100 \%$ & Bacillus & $98 \%$ \\
\hline BITPA3A01 & Acidobacteria & $78 \%$ & Acidobacteria & $78 \%$ & Acidobacteriales & $78 \%$ & Acidobacteriaceae & $78 \%$ & Holophaga & $49 \%$ \\
\hline BITPA3A02 & Firmicutes & $100 \%$ & Bacilli & $100 \%$ & Bacillales & $100 \%$ & Bacillaceae & $100 \%$ & Bacillus & $99 \%$ \\
\hline BITPA3A03 & Acidobacteria & $49 \%$ & Acidobacteria & $49 \%$ & Acidobacteriales & $49 \%$ & Acidobacteriaceae & $49 \%$ & Acidobacterium & $45 \%$ \\
\hline BITPA3А04 & Acidobacteria & $67 \%$ & Acidobacteria & $67 \%$ & Acidobacteriales & $67 \%$ & Acidobacteriaceae & $67 \%$ & Acidobacterium & $62 \%$ \\
\hline BITPA3A05 & Firmicutes & $100 \%$ & Bacilli & $100 \%$ & Bacillales & $100 \%$ & Bacillaceae & $100 \%$ & Bacillus & $100 \%$ \\
\hline BITPA3А06 & Gemmatimonadetes & $96 \%$ & Gemmatimonadetes & $96 \%$ & Gemmatimonadales & $96 \%$ & Gemmatimonadaceae & $96 \%$ & Gemmatimonas & $96 \%$ \\
\hline BITPA3А07 & Firmicutes & $100 \%$ & Bacilli & $100 \%$ & Bacillales & $100 \%$ & Bacillaceae & $100 \%$ & Bacillus & $98 \%$ \\
\hline BITPA3А08 & Proteobacteria & $48 \%$ & Deltaproteobacteria & $37 \%$ & Myxococcales & $18 \%$ & Cystobacterineae & $18 \%$ & Cystobacteraceae & $18 \%$ \\
\hline BITPA3А09 & Firmicutes & $100 \%$ & Bacilli & $100 \%$ & Bacillales & $100 \%$ & Bacillaceae & $100 \%$ & Bacillus & $100 \%$ \\
\hline BITPA3A10 & Firmicutes & $100 \%$ & Bacilli & $100 \%$ & Bacillales & $100 \%$ & Bacillaceae & $99 \%$ & Bacillus & $94 \%$ \\
\hline BITPA3A11 & Firmicutes & $100 \%$ & Bacilli & $100 \%$ & Bacillales & $100 \%$ & Bacillaceae & $100 \%$ & Bacillus & $90 \%$ \\
\hline BITPA3A12 & Proteobacteria & $51 \%$ & Deltaproteobacteria & $30 \%$ & Myxococcales & $15 \%$ & Cystobacterineae & $14 \%$ & Cystobacteraceae & $13 \%$ \\
\hline ВITPA3В01 & Proteobacteria & $53 \%$ & Deltaproteobacteria & $36 \%$ & Myxococcales & $14 \%$ & Cystobacterineae & $14 \%$ & Cystobacteraceae & $14 \%$ \\
\hline ВITPA3В02 & Acidobacteria & $56 \%$ & Acidobacteria & $56 \%$ & Acidobacteriales & $56 \%$ & Acidobacteriaceae & $56 \%$ & Geothrix & $31 \%$ \\
\hline ВІTРА3В03 & Acidobacteria & $50 \%$ & Acidobacteria & $50 \%$ & Acidobacteriales & $50 \%$ & Acidobacteriaceae & $50 \%$ & Acidobacterium & $47 \%$ \\
\hline ВITPA3В04 & Acidobacteria & $57 \%$ & Acidobacteria & $57 \%$ & Acidobacteriales & $57 \%$ & Acidobacteriaceae & $57 \%$ & Holophaga & $48 \%$ \\
\hline ВITPA3В05 & Verrucomicrobia & $99 \%$ & Verrucomicrobiae & $99 \%$ & Verrucomicrobiales & $99 \%$ & Verrucomicrobiaceae & $59 \%$ & Verrucomicrobium & $59 \%$ \\
\hline ВITPA3В06 & Proteobacteria & $100 \%$ & Betaproteobacteria & $98 \%$ & Burkholderiales & $97 \%$ & Comamonadaceae & $53 \%$ & Caenibacterium & $53 \%$ \\
\hline ВITPA3В08 & Acidobacteria & $79 \%$ & Acidobacteria & $79 \%$ & Acidobacteriales & $79 \%$ & Acidobacteriaceae & $79 \%$ & Holophaga & $46 \%$ \\
\hline ВITPА3В09 & Firmicutes & $100 \%$ & Bacilli & $100 \%$ & Bacillales & $100 \%$ & Bacillaceae & $100 \%$ & Bacillus & $100 \%$ \\
\hline BITPA3B10 & Firmicutes & $100 \%$ & Bacilli & $100 \%$ & Bacillales & $100 \%$ & Bacillaceae & $99 \%$ & Bacillus & $98 \%$ \\
\hline
\end{tabular}


ANEXO B - Resultados das comparações das seqüências parciais da região 16S rRNA obtidas em amostras de solo Terra Preta Antropogênica e respectivos solos adjacentes da região Amazônica Central e Oriental, com as amostras depositadas no banco de dados de seqüências de 16S rRNA do RDP II pelo programa Classifier

\begin{tabular}{|c|c|c|c|c|c|c|c|c|c|c|}
\hline Clone & Filo & & Classe & & Ordem & & Familia & & Genero & \\
\hline BITPA3B11 & Acidobacteria & $81 \%$ & Acidobacteria & $81 \%$ & Acidobacteriales & $81 \%$ & Acidobacteriaceae & $81 \%$ & Geothrix & $44 \%$ \\
\hline ВITPA3С01 & Acidobacteria & $38 \%$ & Acidobacteria & $38 \%$ & Acidobacteriales & $38 \%$ & Acidobacteriaceae & $38 \%$ & Holophaga & $24 \%$ \\
\hline BITPA3C02 & Firmicutes & $100 \%$ & Bacilli & $100 \%$ & Bacillales & $100 \%$ & Bacillaceae & $100 \%$ & Bacillus & $98 \%$ \\
\hline ВITPA3C03 & Firmicutes & $51 \%$ & Clostridia & $50 \%$ & Clostridiales & $26 \%$ & Peptococcaceae & $10 \%$ & Cryptanaerobacter & $6 \%$ \\
\hline ВITPA3С04 & Firmicutes & $100 \%$ & Bacilli & $100 \%$ & Bacillales & $100 \%$ & Paenibacillaceae & $100 \%$ & Paenibacillus & $99 \%$ \\
\hline ВITPA3С06 & Proteobacteria & $42 \%$ & Deltaproteobacteria & $25 \%$ & Myxococcales & $22 \%$ & Nannocystineae & $16 \%$ & Nannocystaceae & $16 \%$ \\
\hline ВITPA3С07 & Firmicutes & $46 \%$ & Clostridia & $45 \%$ & Clostridiales & $43 \%$ & Clostridiaceae & $31 \%$ & Thermobrachium & $19 \%$ \\
\hline ВITPA3С 08 & Proteobacteria & $38 \%$ & Deltaproteobacteria & $32 \%$ & Syntrophobacterales & $23 \%$ & Syntrophobacteraceae & $23 \%$ & Desulforhabdus & $16 \%$ \\
\hline ВITPA3С09 & Proteobacteria & $48 \%$ & Deltaproteobacteria & $23 \%$ & Bdellovibrionales & $11 \%$ & Bacteriovoracaceae & $11 \%$ & Peredibacter & $11 \%$ \\
\hline BITPA3C11 & Acidobacteria & $55 \%$ & Acidobacteria & $55 \%$ & Acidobacteriales & $55 \%$ & Acidobacteriaceae & $55 \%$ & Acidobacterium & $50 \%$ \\
\hline BITPA3C12 & Firmicutes & $100 \%$ & Bacilli & $100 \%$ & Bacillales & $100 \%$ & Bacillaceae & $100 \%$ & Bacillus & $99 \%$ \\
\hline BITPA3D02 & Verrucomicrobia & $97 \%$ & Verrucomicrobiae & $97 \%$ & Verrucomicrobiales & $97 \%$ & Verrucomicrobiaceae & $62 \%$ & Verrucomicrobium & $62 \%$ \\
\hline BITPA3D03 & Acidobacteria & $42 \%$ & Acidobacteria & $42 \%$ & Acidobacteriales & $42 \%$ & Acidobacteriaceae & $42 \%$ & Holophaga & $22 \%$ \\
\hline BITPA3D04 & Proteobacteria & $100 \%$ & Alphaproteobacteria & $100 \%$ & Rhizobiales & $93 \%$ & Rhodobiaceae & $43 \%$ & Rhodobium & $43 \%$ \\
\hline BITPA3D05 & Proteobacteria & $71 \%$ & Deltaproteobacteria & $50 \%$ & Syntrophobacterales & $23 \%$ & Syntrophobacteraceae & $19 \%$ & Desulforhabdus & $11 \%$ \\
\hline BITPA3D06 & Proteobacteria & $44 \%$ & Alphaproteobacteria & $17 \%$ & Rhodospirillales & $12 \%$ & Acetobacteraceae & $8 \%$ & Craurococcus & $5 \%$ \\
\hline BITPA3D07 & Firmicutes & $100 \%$ & Bacilli & $100 \%$ & Bacillales & $100 \%$ & Bacillaceae & $100 \%$ & Bacillus & $100 \%$ \\
\hline BITPA3D08 & Firmicutes & $100 \%$ & Bacilli & $100 \%$ & Bacillales & $100 \%$ & Bacillaceae & $100 \%$ & Bacillus & $100 \%$ \\
\hline BITPA3D09 & Proteobacteria & $47 \%$ & Deltaproteobacteria & $29 \%$ & Myxococcales & $12 \%$ & Cystobacterineae & $11 \%$ & Cystobacteraceae & $11 \%$ \\
\hline BITPA3D10 & Thermomicrobia & $42 \%$ & Thermomicrobia & $42 \%$ & Thermomicrobiales & $42 \%$ & Thermomicrobiaceae & $42 \%$ & Thermomicrobium & $42 \%$ \\
\hline BITPA3D11 & Firmicutes & $100 \%$ & Bacilli & $100 \%$ & Bacillales & $100 \%$ & Bacillaceae & $100 \%$ & Bacillus & $99 \%$ \\
\hline BITPA3D12 & Acidobacteria & $47 \%$ & Acidobacteria & $47 \%$ & Acidobacteriales & $47 \%$ & Acidobacteriaceae & $47 \%$ & Acidobacterium & $43 \%$ \\
\hline BITPA3Е01 & Acidobacteria & $98 \%$ & Acidobacteria & $98 \%$ & Acidobacteriales & $98 \%$ & Acidobacteriaceae & $98 \%$ & Acidobacterium & $97 \%$ \\
\hline ВITPA3Е02 & Proteobacteria & $41 \%$ & Betaproteobacteria & $26 \%$ & Burkholderiales & $22 \%$ & Comamonadaceae & $15 \%$ & Caldimonas & $15 \%$ \\
\hline ВITPA3Е03 & Firmicutes & $100 \%$ & Bacilli & $100 \%$ & Bacillales & $100 \%$ & Bacillaceae & $100 \%$ & Bacillus & $98 \%$ \\
\hline BITPA3Е04 & Firmicutes & $37 \%$ & Clostridia & $37 \%$ & Clostridiales & $33 \%$ & Clostridiaceae & $18 \%$ & Faecalibacterium & $13 \%$ \\
\hline BITPA3E05 & Acidobacteria & $40 \%$ & Acidobacteria & $40 \%$ & Acidobacteriales & $40 \%$ & Acidobacteriaceae & $40 \%$ & Holophaga & $27 \%$ \\
\hline BITPA3E06 & Proteobacteria & $34 \%$ & Deltaproteobacteria & $18 \%$ & Myxococcales & $8 \%$ & Cystobacterineae & $8 \%$ & Cystobacteraceae & $8 \%$ \\
\hline BITPA3Е07 & Firmicutes & $100 \%$ & Bacilli & $100 \%$ & Bacillales & $100 \%$ & Bacillaceae & $99 \%$ & Bacillus & $98 \%$ \\
\hline BITPA3Е08 & Acidobacteria & $53 \%$ & Acidobacteria & $53 \%$ & Acidobacteriales & $53 \%$ & Acidobacteriaceae & $53 \%$ & Acidobacterium & $43 \%$ \\
\hline ВITPA3Е09 & Thermomicrobia & $42 \%$ & Thermomicrobia & $42 \%$ & Thermomicrobiales & $42 \%$ & Thermomicrobiaceae & $42 \%$ & Thermomicrobium & $42 \%$ \\
\hline BITPA3E10 & Acidobacteria & $52 \%$ & Acidobacteria & $52 \%$ & Acidobacteriales & $52 \%$ & Acidobacteriaceae & $52 \%$ & Acidobacterium & $31 \%$ \\
\hline BITPA3E11 & Acidobacteria & $46 \%$ & Acidobacteria & $46 \%$ & Acidobacteriales & $46 \%$ & Acidobacteriaceae & $46 \%$ & Acidobacterium & $43 \%$ \\
\hline BITPA3E12 & Acidobacteria & $44 \%$ & Acidobacteria & $44 \%$ & Acidobacteriales & $44 \%$ & Acidobacteriaceae & $44 \%$ & Acidobacterium & $35 \%$ \\
\hline
\end{tabular}


ANEXO B - Resultados das comparações das seqüências parciais da região 16S rRNA obtidas em amostras de solo Terra Preta Antropogênica e respectivos solos adjacentes da região Amazônica Central e Oriental, com as amostras depositadas no banco de dados de seqüências de 16S rRNA do RDP II pelo programa Classifier

\begin{tabular}{|c|c|c|c|c|c|c|c|c|c|c|}
\hline Clone & Filo & & Classe & & Ordem & & Familia & & Genero & \\
\hline BITPA3F01 & Firmicutes & $100 \%$ & Bacilli & $100 \%$ & Bacillales & $100 \%$ & Bacillaceae & $100 \%$ & Bacillus & $100 \%$ \\
\hline BITPA3F02 & Proteobacteria & $60 \%$ & Deltaproteobacteria & $39 \%$ & Bdellovibrionales & $20 \%$ & Bacteriovoracaceae & $20 \%$ & Peredibacter & $20 \%$ \\
\hline BITPA3F03 & Proteobacteria & $53 \%$ & Epsilonproteobacteria & $14 \%$ & Nautiliales & $14 \%$ & Nautiliaceae & $14 \%$ & Lebetimonas & $11 \%$ \\
\hline BITPA3F04 & Proteobacteria & $67 \%$ & Deltaproteobacteria & $42 \%$ & Desulfobacterales & $24 \%$ & Desulfobacteraceae & $21 \%$ & Desulforegula & $18 \%$ \\
\hline BITPA3F05 & Acidobacteria & $43 \%$ & Acidobacteria & $43 \%$ & Acidobacteriales & $43 \%$ & Acidobacteriaceae & $43 \%$ & Acidobacterium & $27 \%$ \\
\hline BITPA3F06 & Firmicutes & $39 \%$ & Clostridia & $37 \%$ & Clostridiales & $36 \%$ & Clostridiaceae & $29 \%$ & Faecalibacterium & $25 \%$ \\
\hline BITPA3F07 & Thermomicrobia & $40 \%$ & Thermomicrobia & $40 \%$ & Thermomicrobiales & $40 \%$ & Thermomicrobiaceae & $40 \%$ & Thermomicrobium & $40 \%$ \\
\hline BITPA3F08 & Proteobacteria & $73 \%$ & Deltaproteobacteria & $67 \%$ & Syntrophobacterales & $47 \%$ & Syntrophaceae & $36 \%$ & Desulfobacca & $30 \%$ \\
\hline BITPA3F09 & Firmicutes & $49 \%$ & Clostridia & $48 \%$ & Clostridiales & $45 \%$ & Clostridiaceae & $25 \%$ & Parasporobacterium & $17 \%$ \\
\hline BITPA3F 10 & Firmicutes & $100 \%$ & Bacilli & $100 \%$ & Bacillales & $100 \%$ & Bacillaceae & $100 \%$ & Bacillus & $99 \%$ \\
\hline BITPA3F11 & Firmicutes & $100 \%$ & Bacilli & $100 \%$ & Bacillales & $100 \%$ & Bacillaceae & $100 \%$ & Bacillus & $99 \%$ \\
\hline BITPA3F 12 & Firmicutes & $100 \%$ & Bacilli & $100 \%$ & Bacillales & $100 \%$ & Bacillaceae & $99 \%$ & Bacillus & $98 \%$ \\
\hline BITPA3G01 & Proteobacteria & $100 \%$ & Betaproteobacteria & $100 \%$ & Burkholderiales & $100 \%$ & Incertae sedis 5 & $89 \%$ & Rubrivivax & $59 \%$ \\
\hline BITPA3G02 & Acidobacteria & $35 \%$ & Acidobacteria & $35 \%$ & Acidobacteriales & $35 \%$ & Acidobacteriaceae & $35 \%$ & Acidobacterium & $34 \%$ \\
\hline BITPA3G03 & Gemmatimonadetes & $100 \%$ & Gemmatimonadetes & $100 \%$ & Gemmatimonadales & $100 \%$ & Gemmatimonadaceae & $100 \%$ & Gemmatimonas & $100 \%$ \\
\hline BITPA3G05 & Firmicutes & $100 \%$ & Bacilli & $100 \%$ & Bacillales & $100 \%$ & Bacillaceae & $99 \%$ & Bacillus & $56 \%$ \\
\hline BITPA3G06 & Proteobacteria & $45 \%$ & Deltaproteobacteria & $41 \%$ & Myxococcales & $38 \%$ & Cystobacterineae & $28 \%$ & Cystobacteraceae & $27 \%$ \\
\hline BITPA3G07 & Firmicutes & $100 \%$ & Bacilli & $100 \%$ & Bacillales & $100 \%$ & Bacillaceae & $99 \%$ & Bacillus & $96 \%$ \\
\hline BITPA3G08 & Genera_incertae_sedis_OP10 & $100 \%$ & OP10 & $100 \%$ & & & & & & \\
\hline BITPA3G09 & Acidobacteria & $41 \%$ & Acidobacteria & $41 \%$ & Acidobacteriales & $41 \%$ & Acidobacteriaceae & $41 \%$ & Holophaga & $40 \%$ \\
\hline BITPA3G10 & Firmicutes & $47 \%$ & Clostridia & $47 \%$ & Clostridiales & $21 \%$ & Peptococcaceae & $10 \%$ & Thermoterrabacterium & $9 \%$ \\
\hline BITPA3G11 & Proteobacteria & $100 \%$ & Alphaproteobacteria & $100 \%$ & Rhizobiales & $100 \%$ & Bradyrhizobiaceae & $100 \%$ & Bradyrhizobium & $96 \%$ \\
\hline BITPA3G12 & Proteobacteria & $38 \%$ & Gammaproteobacteria & $16 \%$ & Chromatiales & $13 \%$ & Chromatiaceae & $9 \%$ & Thiorhodococcus & $5 \%$ \\
\hline ВITPA3Н01 & Proteobacteria & $48 \%$ & Alphaproteobacteria & $20 \%$ & Rhodospirillales & $13 \%$ & Acetobacteraceae & $8 \%$ & Teichococcus & $4 \%$ \\
\hline ВITPA3H02 & Verrucomicrobia & $99 \%$ & Verrucomicrobiae & $99 \%$ & Verrucomicrobiales & $99 \%$ & Verrucomicrobiaceae & $51 \%$ & Verrucomicrobium & $51 \%$ \\
\hline ВITPA3Н03 & Acidobacteria & $38 \%$ & Acidobacteria & $38 \%$ & Acidobacteriales & $38 \%$ & Acidobacteriaceae & $38 \%$ & Holophaga & $26 \%$ \\
\hline ВITPA3H04 & Acidobacteria & $45 \%$ & Acidobacteria & $45 \%$ & Acidobacteriales & $45 \%$ & Acidobacteriaceae & $45 \%$ & Acidobacterium & $32 \%$ \\
\hline BITPA3H05 & Acidobacteria & $55 \%$ & Acidobacteria & $55 \%$ & Acidobacteriales & $55 \%$ & Acidobacteriaceae & $55 \%$ & Holophaga & $40 \%$ \\
\hline ВITPA3H06 & Firmicutes & $100 \%$ & Bacilli & $100 \%$ & Bacillales & $100 \%$ & Bacillaceae & $100 \%$ & Bacillus & $100 \%$ \\
\hline ВITPA3H07 & Acidobacteria & $88 \%$ & Acidobacteria & $88 \%$ & Acidobacteriales & $88 \%$ & Acidobacteriaceae & $88 \%$ & Holophaga & $48 \%$ \\
\hline ВITPA3Н08 & Proteobacteria & $46 \%$ & Deltaproteobacteria & $31 \%$ & Myxococcales & $19 \%$ & Cystobacterineae & $19 \%$ & Cystobacteraceae & $19 \%$ \\
\hline ВITPA3Н09 & Acidobacteria & $34 \%$ & Acidobacteria & $34 \%$ & Acidobacteriales & $34 \%$ & Acidobacteriaceae & $34 \%$ & Holophaga & $28 \%$ \\
\hline BITPA3H10 & Firmicutes & $100 \%$ & Bacilli & $100 \%$ & Bacillales & $100 \%$ & Bacillaceae & $100 \%$ & Bacillus & $100 \%$ \\
\hline BITPA3H11 & Acidobacteria & $66 \%$ & Acidobacteria & $66 \%$ & Acidobacteriales & $66 \%$ & Acidobacteriaceae & $66 \%$ & Acidobacterium & $60 \%$ \\
\hline
\end{tabular}


ANEXO B - Resultados das comparações das seqüências parciais da região 16S rRNA obtidas em amostras de solo Terra Preta Antropogênica e respectivos solos adjacentes da região Amazônica Central e Oriental, com as amostras depositadas no banco de dados de seqüências de 16S rRNA do RDP II pelo programa Classifier

\begin{tabular}{|c|c|c|c|c|c|c|c|c|c|c|}
\hline Clone & Filo & & Classe & & Ordem & & Familia & & Genero & \\
\hline BIADJ1A01 & Firmicutes & $52 \%$ & Clostridia & $52 \%$ & Clostridiales & $45 \%$ & Clostridiaceae & $25 \%$ & Faecalibacterium & $20 \%$ \\
\hline BIADJ1A03 & Proteobacteria & $100 \%$ & Alphaproteobacteria & $100 \%$ & Rhizobiales & $58 \%$ & Hyphomicrobiaceae & $29 \%$ & Rhodoplanes & $13 \%$ \\
\hline BIADJ1A04 & Firmicutes & $37 \%$ & Clostridia & $37 \%$ & Clostridiales & $31 \%$ & Clostridiaceae & $21 \%$ & Faecalibacterium & $7 \%$ \\
\hline BIADJ1A05 & Acidobacteria & $99 \%$ & Acidobacteria & $99 \%$ & Acidobacteriales & $99 \%$ & Acidobacteriaceae & $99 \%$ & Acidobacterium & $98 \%$ \\
\hline BIADJ1A06 & Proteobacteria & $78 \%$ & Deltaproteobacteria & $62 \%$ & Desulfuromonales & $22 \%$ & Geobacteraceae & $17 \%$ & Trichlorobacter & $17 \%$ \\
\hline BIADJ1A07 & Proteobacteria & $43 \%$ & Deltaproteobacteria & $36 \%$ & Myxococcales & $34 \%$ & Cystobacterineae & $33 \%$ & Cystobacteraceae & $32 \%$ \\
\hline BIADJ1A08 & Proteobacteria & $100 \%$ & Gammaproteobacteria & $85 \%$ & Legionellales & $71 \%$ & Coxiellaceae & $71 \%$ & Rickettsiella & $51 \%$ \\
\hline BIADJ1A09 & Proteobacteria & $83 \%$ & Alphaproteobacteria & $35 \%$ & Rhodospirillales & $14 \%$ & Rhodospirillaceae & $14 \%$ & Tistrella & $13 \%$ \\
\hline BIADJ1A10 & Proteobacteria & $44 \%$ & Deltaproteobacteria & $38 \%$ & Myxococcales & $30 \%$ & Cystobacterineae & $22 \%$ & Cystobacteraceae & $22 \%$ \\
\hline BIADJ1A11 & Nitrospira & $100 \%$ & Nitrospira & $100 \%$ & Nitrospirales & $100 \%$ & Nitrospiraceae & $100 \%$ & Nitrospira & $100 \%$ \\
\hline BIADJ1A12 & Proteobacteria & $35 \%$ & Deltaproteobacteria & $30 \%$ & Myxococcales & $26 \%$ & Cystobacterineae & $25 \%$ & Cystobacteraceae & $25 \%$ \\
\hline BIADJ1B01 & Proteobacteria & $100 \%$ & Alphaproteobacteria & $100 \%$ & Rhizobiales & $100 \%$ & Bradyrhizobiaceae & $100 \%$ & Afipia & $52 \%$ \\
\hline BIADJ1B02 & Acidobacteria & $39 \%$ & Acidobacteria & $39 \%$ & Acidobacteriales & $39 \%$ & Acidobacteriaceae & $39 \%$ & Acidobacterium & $38 \%$ \\
\hline BIADJ1B03 & Firmicutes & $42 \%$ & Clostridia & $41 \%$ & Clostridiales & $39 \%$ & Clostridiaceae & $27 \%$ & Caminicella & $12 \%$ \\
\hline BIADJ1B04 & Proteobacteria & $48 \%$ & Deltaproteobacteria & $30 \%$ & Syntrophobacterales & $25 \%$ & Syntrophobacteraceae & $25 \%$ & Desulforhabdus & $13 \%$ \\
\hline BIADJ1B05 & Acidobacteria & $100 \%$ & Acidobacteria & $100 \%$ & Acidobacteriales & $100 \%$ & Acidobacteriaceae & $100 \%$ & Acidobacterium & $99 \%$ \\
\hline BIADJ1B07 & Proteobacteria & $100 \%$ & Gammaproteobacteria & $84 \%$ & Legionellales & $68 \%$ & Coxiellaceae & $68 \%$ & Rickettsiella & $49 \%$ \\
\hline BIADJ1B08 & Thermomicrobia & $40 \%$ & Thermomicrobia & $40 \%$ & Thermomicrobiales & $40 \%$ & Thermomicrobiaceae & $40 \%$ & Thermomicrobium & $40 \%$ \\
\hline BIADJ1B09 & Proteobacteria & $100 \%$ & Betaproteobacteria & $100 \%$ & Burkholderiales & $100 \%$ & Burkholderiaceae & $100 \%$ & Burkholderia & $100 \%$ \\
\hline BIADJ1B10 & Acidobacteria & $27 \%$ & Acidobacteria & $27 \%$ & Acidobacteriales & $27 \%$ & Acidobacteriaceae & $27 \%$ & Acidobacterium & $27 \%$ \\
\hline BIADJ1B11 & Proteobacteria & $92 \%$ & Deltaproteobacteria & $91 \%$ & Desulfurellales & $77 \%$ & Desulfurellaceae & $77 \%$ & Hippea & $77 \%$ \\
\hline BIADJ1B12 & Proteobacteria & $43 \%$ & Deltaproteobacteria & $37 \%$ & Myxococcales & $35 \%$ & Cystobacterineae & $35 \%$ & Cystobacteraceae & $34 \%$ \\
\hline BIADJ1C01 & Proteobacteria & $38 \%$ & Deltaproteobacteria & $32 \%$ & Myxococcales & $30 \%$ & Cystobacterineae & $27 \%$ & Cystobacteraceae & $27 \%$ \\
\hline BIADJ1C02 & Firmicutes & $63 \%$ & Clostridia & $61 \%$ & Clostridiales & $56 \%$ & Lachnospiraceae & $38 \%$ & Catonella & $23 \%$ \\
\hline BIADJ1C03 & Proteobacteria & $35 \%$ & Deltaproteobacteria & $25 \%$ & Myxococcales & $18 \%$ & Cystobacterineae & $15 \%$ & Cystobacteraceae & $14 \%$ \\
\hline BIADJ1C04 & Firmicutes & $34 \%$ & Clostridia & $34 \%$ & Clostridiales & $21 \%$ & Peptococcaceae & $16 \%$ & Pelotomaculum & $13 \%$ \\
\hline BIADJ1C05 & Nitrospira & $100 \%$ & Nitrospira & $100 \%$ & Nitrospirales & $100 \%$ & Nitrospiraceae & $100 \%$ & Nitrospira & $100 \%$ \\
\hline BIADJ1C06 & Proteobacteria & $42 \%$ & Betaproteobacteria & $24 \%$ & Burkholderiales & $19 \%$ & Alcaligenaceae & $15 \%$ & Sutterella & $15 \%$ \\
\hline BIADJ1C07 & Proteobacteria & $81 \%$ & Deltaproteobacteria & $69 \%$ & Desulfurellales & $44 \%$ & Desulfurellaceae & $44 \%$ & Hippea & $44 \%$ \\
\hline BIADJ1C08 & Acidobacteria & $45 \%$ & Acidobacteria & $45 \%$ & Acidobacteriales & $45 \%$ & Acidobacteriaceae & $45 \%$ & Acidobacterium & $45 \%$ \\
\hline BIADJ1C09 & Proteobacteria & $59 \%$ & Deltaproteobacteria & $57 \%$ & Myxococcales & $54 \%$ & Cystobacterineae & $52 \%$ & Cystobacteraceae & $51 \%$ \\
\hline BIADJ1C10 & Proteobacteria & $100 \%$ & ammaproteobacteria & $89 \%$ & Legionellales & $63 \%$ & Coxiellaceae & $63 \%$ & Rickettsiella & $45 \%$ \\
\hline BIADJ1C11 & Proteobacteria & $53 \%$ & Deltaproteobacteria & $46 \%$ & Syntrophobacterales & $25 \%$ & Syntrophobacteraceae & $24 \%$ & Desulforhabdus & $16 \%$ \\
\hline BIADJ1D01 & Proteobacteria & $100 \%$ & Gammaproteobacteria & $100 \%$ & Legionellales & $100 \%$ & Coxiellaceae & $100 \%$ & Aquicella & $100 \%$ \\
\hline
\end{tabular}


ANEXO B - Resultados das comparações das seqüências parciais da região 16S rRNA obtidas em amostras de solo Terra Preta Antropogênica e respectivos solos adjacentes da região Amazônica Central e Oriental, com as amostras depositadas no banco de dados de seqüências de 16S rRNA do RDP II pelo programa Classifier

\begin{tabular}{|c|c|c|c|c|c|c|c|c|c|c|}
\hline Clone & Filo & & Classe & & Ordem & & Família & & Gênero & \\
\hline BIADJ1D02 & Proteobacteria & $52 \%$ & Deltaproteobacteria & $42 \%$ & Myxococcales & $37 \%$ & Cystobacterineae & $34 \%$ & Cystobacteraceae & $34 \%$ \\
\hline BIADJ1D03 & Proteobacteria & $73 \%$ & Alphaproteobacteria & $70 \%$ & Rhizobiales & $70 \%$ & Methylobacteriaceae & $55 \%$ & Microvirga & $55 \%$ \\
\hline BIADJ1D05 & Proteobacteria & $77 \%$ & Deltaproteobacteria & $58 \%$ & Desulfurellales & $25 \%$ & Desulfurellaceae & $25 \%$ & Hippea & $25 \%$ \\
\hline BIADJ1D06 & Proteobacteria & $31 \%$ & Deltaproteobacteria & $13 \%$ & Myxococcales & $8 \%$ & Nannocystineae & $6 \%$ & Nannocystaceae & $6 \%$ \\
\hline BIADJ1D07 & Proteobacteria & $100 \%$ & Betaproteobacteria & $100 \%$ & Burkholderiales & $100 \%$ & Burkholderiaceae & $100 \%$ & Burkholderia & $100 \%$ \\
\hline BIADJ1D08 & Firmicutes & $46 \%$ & Clostridia & $44 \%$ & Thermoanaerobacteriales & $29 \%$ & Thermoanaerobacteriaceae & $29 \%$ & Thermacetogenium & $26 \%$ \\
\hline BIADJ1D09 & Proteobacteria & $49 \%$ & Deltaproteobacteria & $46 \%$ & Myxococcales & $41 \%$ & Cystobacterineae & $37 \%$ & Cystobacteraceae & $37 \%$ \\
\hline BIADJ1D10 & Firmicutes & $41 \%$ & Clostridia & $41 \%$ & Clostridiales & $27 \%$ & Clostridiaceae & $20 \%$ & Thermobrachium & $11 \%$ \\
\hline BIADJ1D11 & Proteobacteria & $68 \%$ & Deltaproteobacteria & $49 \%$ & Syntrophobacterales & $14 \%$ & Syntrophaceae & $14 \%$ & Desulfobacca & $8 \%$ \\
\hline BIADJ1E01 & Proteobacteria & $40 \%$ & Deltaproteobacteria & $31 \%$ & Myxococcales & $18 \%$ & Cystobacterineae & $17 \%$ & Cystobacteraceae & $17 \%$ \\
\hline BIADJ1E02 & Acidobacteria & $61 \%$ & Acidobacteria & $61 \%$ & Acidobacteriales & $61 \%$ & Acidobacteriaceae & $61 \%$ & Acidobacterium & $60 \%$ \\
\hline BIADJ1E03 & Proteobacteria & $54 \%$ & Deltaproteobacteria & $45 \%$ & Syntrophobacterales & $33 \%$ & Syntrophobacteraceae & $33 \%$ & Desulforhabdus & $18 \%$ \\
\hline BIADJ1E04 & Proteobacteria & $44 \%$ & Deltaproteobacteria & $35 \%$ & Desulfobacterales & $10 \%$ & Desulfobulbaceae & $7 \%$ & Desulfofustis & $6 \%$ \\
\hline BIADJ1E05 & Proteobacteria & $43 \%$ & Gammaproteobacteria & $18 \%$ & Aeromonadales & $6 \%$ & Aeromonadaceae & $6 \%$ & Oceanisphaera & $6 \%$ \\
\hline BIADJ1E06 & Proteobacteria & $77 \%$ & Deltaproteobacteria & $69 \%$ & Desulfurellales & $41 \%$ & Desulfurellaceae & $41 \%$ & Hippea & $41 \%$ \\
\hline BIADJ1E07 & Proteobacteria & $88 \%$ & Deltaproteobacteria & $84 \%$ & Desulfurellales & $67 \%$ & Desulfurellaceae & $67 \%$ & Hippea & $67 \%$ \\
\hline BIADJ1E08 & Proteobacteria & $57 \%$ & Deltaproteobacteria & $33 \%$ & Myxococcales & $24 \%$ & Cystobacterineae & $23 \%$ & Cystobacteraceae & $23 \%$ \\
\hline BIADJ1E10 & Acidobacteria & $100 \%$ & Acidobacteria & $100 \%$ & Acidobacteriales & $100 \%$ & Acidobacteriaceae & $100 \%$ & Acidobacterium & $100 \%$ \\
\hline BIADJ1E11 & Proteobacteria & $71 \%$ & Deltaproteobacteria & $58 \%$ & Myxococcales & $26 \%$ & Cystobacterineae & $26 \%$ & Cystobacteraceae & $23 \%$ \\
\hline BIADJ1F01 & Acidobacteria & $100 \%$ & Acidobacteria & $100 \%$ & Acidobacteriales & $100 \%$ & Acidobacteriaceae & $100 \%$ & Acidobacterium & $100 \%$ \\
\hline BIADJ1F02 & Verrucomicrobia & $98 \%$ & Verrucomicrobiae & $98 \%$ & Verrucomicrobiales & $98 \%$ & Xiphinematobacteriaceae & $87 \%$ & Xiphinematobacter & $87 \%$ \\
\hline BIADJ1F03 & Acidobacteria & $44 \%$ & Acidobacteria & $44 \%$ & Acidobacteriales & $44 \%$ & Acidobacteriaceae & $44 \%$ & Acidobacterium & $44 \%$ \\
\hline BIADJ1F04 & Proteobacteria & $94 \%$ & Deltaproteobacteria & $92 \%$ & Desulfurellales & $73 \%$ & Desulfurellaceae & $73 \%$ & Hippea & $73 \%$ \\
\hline BIADJ1F05 & Proteobacteria & $38 \%$ & Deltaproteobacteria & $20 \%$ & Syntrophobacterales & $16 \%$ & Syntrophobacteraceae & $15 \%$ & Thermodesulforhabdus & $9 \%$ \\
\hline BIADJ1F06 & Firmicutes & $43 \%$ & Clostridia & $42 \%$ & Clostridiales & $41 \%$ & Lachnospiraceae & $17 \%$ & Catonella & $17 \%$ \\
\hline BIADJ1F08 & Proteobacteria & $29 \%$ & Deltaproteobacteria & $15 \%$ & Myxococcales & $10 \%$ & Cystobacterineae & $5 \%$ & Cystobacteraceae & $5 \%$ \\
\hline BIADJ1F09 & Proteobacteria & $36 \%$ & Deltaproteobacteria & $32 \%$ & Myxococcales & $31 \%$ & Cystobacterineae & $30 \%$ & Cystobacteraceae & $30 \%$ \\
\hline BIADJ1F10 & Firmicutes & $44 \%$ & Clostridia & $44 \%$ & Clostridiales & $24 \%$ & Peptococcaceae & $12 \%$ & Pelotomaculum & $11 \%$ \\
\hline BIADJ1F11 & Proteobacteria & $41 \%$ & Deltaproteobacteria & $27 \%$ & Syntrophobacterales & $23 \%$ & Syntrophobacteraceae & $23 \%$ & Desulforhabdus & $12 \%$ \\
\hline BIADJ1G01 & Proteobacteria & $24 \%$ & Deltaproteobacteria & $15 \%$ & Myxococcales & $8 \%$ & Cystobacterineae & $7 \%$ & Cystobacteraceae & $5 \%$ \\
\hline BIADJ1G02 & Proteobacteria & $40 \%$ & Deltaproteobacteria & $27 \%$ & Myxococcales & $22 \%$ & Cystobacterineae & $15 \%$ & Cystobacteraceae & $15 \%$ \\
\hline BIADJ1G03 & Firmicutes & $32 \%$ & Clostridia & $30 \%$ & Clostridiales & $26 \%$ & Clostridiaceae & $21 \%$ & Thermobrachium & $11 \%$ \\
\hline BIADJ1G04 & Proteobacteria & $100 \%$ & Alphaproteobacteria & $100 \%$ & Rhizobiales & $100 \%$ & Hyphomicrobiaceae & $37 \%$ & Blastochloris & $32 \%$ \\
\hline BIADJ1G05 & Proteobacteria & $100 \%$ & Gammaproteobacteria & $100 \%$ & Legionellales & $100 \%$ & Coxiellaceae & $100 \%$ & Aquicella & $100 \%$ \\
\hline
\end{tabular}


ANEXO B - Resultados das comparações das seqüências parciais da região 16S rRNA obtidas em amostras de solo Terra Preta Antropogênica e respectivos solos adjacentes da região Amazônica Central e Oriental, com as amostras depositadas no banco de dados de seqüências de 16S rRNA do RDP II pelo programa Classifier

\begin{tabular}{|c|c|c|c|c|c|c|c|c|c|c|}
\hline Clone & Filo & & Classe & & Ordem & & Família & & Gênero & uaç̧a) \\
\hline BIADJ1G06 & Firmicutes & $100 \%$ & Bacilli & $100 \%$ & Bacillales & $100 \%$ & Caryophanaceae & $63 \%$ & Caryophanon & $63 \%$ \\
\hline BIADJ1G07 & Proteobacteria & $87 \%$ & Deltaproteobacteria & $81 \%$ & Desulfurellales & $71 \%$ & Desulfurellaceae & $71 \%$ & Hippea & $71 \%$ \\
\hline BIADJ1G08 & Proteobacteria & $100 \%$ & Betaproteobacteria & $100 \%$ & Burkholderiales & $100 \%$ & Burkholderiaceae & $100 \%$ & Burkholderia & $100 \%$ \\
\hline BIADJ1G09 & Proteobacteria & $46 \%$ & Deltaproteobacteria & $28 \%$ & Myxococcales & $17 \%$ & Cystobacterineae & $17 \%$ & Cystobacteraceae & $17 \%$ \\
\hline BIADJ1G10 & Proteobacteria & $100 \%$ & Betaproteobacteria & $100 \%$ & Burkholderiales & $100 \%$ & Burkholderiaceae & $100 \%$ & Burkholderia & $100 \%$ \\
\hline BIADJ1G11 & Proteobacteria & $44 \%$ & Deltaproteobacteria & $40 \%$ & Myxococcales & $40 \%$ & Cystobacterineae & $29 \%$ & Cystobacteraceae & $28 \%$ \\
\hline BIADJ1H01 & Proteobacteria & $100 \%$ & Alphaproteobacteria & $100 \%$ & Rhizobiales & $99 \%$ & Beijerinckiaceae & $87 \%$ & Methylocapsa & $79 \%$ \\
\hline BIADJ1H02 & Proteobacteria & $100 \%$ & Alphaproteobacteria & $100 \%$ & Rhizobiales & $100 \%$ & Hyphomicrobiaceae & $82 \%$ & Rhodoplanes & $68 \%$ \\
\hline BIADJ1H03 & Spirochaetes & $28 \%$ & Spirochaetes & $28 \%$ & Spirochaetales & $28 \%$ & Leptospiraceae & $28 \%$ & Leptonema & $28 \%$ \\
\hline BIADJ1H04 & Proteobacteria & $38 \%$ & Deltaproteobacteria & $22 \%$ & Myxococcales & $19 \%$ & Nannocystineae & $17 \%$ & Nannocystaceae & $17 \%$ \\
\hline BIADJ1H05 & Proteobacteria & $55 \%$ & Deltaproteobacteria & $51 \%$ & Desulfuromonales & $30 \%$ & Desulfuromonaceae & $30 \%$ & Malonomonas & $30 \%$ \\
\hline BIADJ1H06 & Proteobacteria & $89 \%$ & Deltaproteobacteria & $83 \%$ & Desulfurellales & $53 \%$ & Desulfurellaceae & $53 \%$ & Hippea & $53 \%$ \\
\hline BIADJ1H07 & Proteobacteria & $61 \%$ & Deltaproteobacteria & $54 \%$ & Myxococcales & $52 \%$ & Cystobacterineae & $46 \%$ & Cystobacteraceae & $43 \%$ \\
\hline BIADJ1H08 & Proteobacteria & $100 \%$ & Alphaproteobacteria & $100 \%$ & Rhizobiales & $100 \%$ & Hyphomicrobiaceae & $61 \%$ & Rhodoplanes & $50 \%$ \\
\hline BIADJ1H09 & Proteobacteria & $36 \%$ & Deltaproteobacteria & $25 \%$ & Syntrophobacterales & $19 \%$ & Syntrophobacteraceae & $18 \%$ & Thermodesulforhabdus & $9 \%$ \\
\hline BIADJ1H10 & Proteobacteria & $32 \%$ & Deltaproteobacteria & $22 \%$ & Myxococcales & $14 \%$ & Nannocystineae & $11 \%$ & Nannocystaceae & $11 \%$ \\
\hline BIADJ1H11 & Firmicutes & $37 \%$ & Clostridia & $37 \%$ & Clostridiales & $24 \%$ & Peptococcaceae & $10 \%$ & Pelotomaculum & $9 \%$ \\
\hline BIADJ2A01 & Firmicutes & $36 \%$ & Clostridia & $36 \%$ & Clostridiales & $35 \%$ & Clostridiaceae & $18 \%$ & Caminicella & $8 \%$ \\
\hline BIADJ2A02 & Firmicutes & $55 \%$ & Clostridia & $55 \%$ & Clostridiales & $53 \%$ & Lachnospiraceae & $38 \%$ & Catonella & $27 \%$ \\
\hline BIADJ2A03 & Proteobacteria & $47 \%$ & Deltaproteobacteria & $38 \%$ & Syntrophobacterales & $28 \%$ & Syntrophobacteraceae & $28 \%$ & Desulforhabdus & $18 \%$ \\
\hline BIADJ2A04 & Proteobacteria & $36 \%$ & Alphaproteobacteria & $15 \%$ & Rhodospirillales & $8 \%$ & Acetobacteraceae & $5 \%$ & Craurococcus & $2 \%$ \\
\hline BIADJ2A05 & Proteobacteria & $37 \%$ & Alphaproteobacteria & $17 \%$ & Rhodospirillales & $11 \%$ & Rhodospirillaceae & $7 \%$ & Inquilinus & $5 \%$ \\
\hline BIADJ2A07 & Proteobacteria & $51 \%$ & Deltaproteobacteria & $34 \%$ & Myxococcales & $27 \%$ & Cystobacterineae & $24 \%$ & Cystobacteraceae & $24 \%$ \\
\hline BIADJ2A08 & Proteobacteria & $100 \%$ & Alphaproteobacteria & $100 \%$ & Rhizobiales & $95 \%$ & Methylobacteriaceae & $48 \%$ & Microvirga & $48 \%$ \\
\hline BIADJ2A09 & Proteobacteria & $42 \%$ & Betaproteobacteria & $16 \%$ & Burkholderiales & $16 \%$ & Alcaligenaceae & $7 \%$ & Sutterella & $6 \%$ \\
\hline BIADJ2A10 & Verrucomicrobia & $97 \%$ & Verrucomicrobiae & $97 \%$ & Verrucomicrobiales & $97 \%$ & Xiphinematobacteriaceae & $91 \%$ & Xiphinematobacter & $91 \%$ \\
\hline BIADJ2A11 & Firmicutes & $100 \%$ & Bacilli & $100 \%$ & Bacillales & $100 \%$ & Caryophanaceae & $57 \%$ & Caryophanon & $57 \%$ \\
\hline BIADJ2A 12 & Verrucomicrobia & $29 \%$ & Verrucomicrobiae & $29 \%$ & Verrucomicrobiales & $29 \%$ & Opitutaceae & $27 \%$ & Opitutus & $27 \%$ \\
\hline BIADJ2B01 & Proteobacteria & $37 \%$ & Deltaproteobacteria & $21 \%$ & Syntrophobacterales & $21 \%$ & Syntrophobacteraceae & $21 \%$ & Desulfovirga & $14 \%$ \\
\hline BIADJ2B02 & Proteobacteria & $43 \%$ & Deltaproteobacteria & $23 \%$ & Syntrophobacterales & $17 \%$ & Syntrophobacteraceae & $17 \%$ & Thermodesulforhabdus & $9 \%$ \\
\hline BIADJ2B03 & Proteobacteria & $91 \%$ & Deltaproteobacteria & $89 \%$ & Desulfurellales & $55 \%$ & Desulfurellaceae & $55 \%$ & Hippea & $55 \%$ \\
\hline BIADJ2B04 & Proteobacteria & $96 \%$ & Deltaproteobacteria & $96 \%$ & Desulfurellales & $61 \%$ & Desulfurellaceae & $61 \%$ & Hippea & $61 \%$ \\
\hline BIADJ2B05 & Proteobacteria & $40 \%$ & Deltaproteobacteria & $26 \%$ & Syntrophobacterales & $22 \%$ & Syntrophobacteraceae & $22 \%$ & Desulfovirga & $19 \%$ \\
\hline BIADJ2B06 & Proteobacteria & $52 \%$ & Deltaproteobacteria & $42 \%$ & Myxococcales & $26 \%$ & Cystobacterineae & $24 \%$ & Cystobacteraceae & $24 \%$ \\
\hline
\end{tabular}


ANEXO B - Resultados das comparações das seqüências parciais da região 16S rRNA obtidas em amostras de solo Terra Preta Antropogênica e respectivos solos adjacentes da região Amazônica Central e Oriental, com as amostras depositadas no banco de dados de seqüências de 16S rRNA do RDP II pelo programa Classifier

\begin{tabular}{|c|c|c|c|c|c|c|c|c|c|c|}
\hline Clone & Filo & & Classe & & Ordem & & Família & & Gênero & \\
\hline BIADJ2B07 & Proteobacteria & $56 \%$ & Deltaproteobacteria & $48 \%$ & Syntrophobacterales & $31 \%$ & Syntrophobacteraceae & $31 \%$ & Desulforhabdus & $12 \%$ \\
\hline BIADJ2B08 & Acidobacteria & $100 \%$ & Acidobacteria & $100 \%$ & Acidobacteriales & $100 \%$ & Acidobacteriaceae & $100 \%$ & Acidobacterium & $100 \%$ \\
\hline BIADJ2B09 & Proteobacteria & $100 \%$ & Alphaproteobacteria & $54 \%$ & Rhizobiales & $34 \%$ & Methylobacteriaceae & $19 \%$ & Microvirga & $19 \%$ \\
\hline BIADJ2B10 & Proteobacteria & $49 \%$ & Deltaproteobacteria & $43 \%$ & Myxococcales & $41 \%$ & Cystobacterineae & $28 \%$ & Cystobacteraceae & $28 \%$ \\
\hline BIADJ2B11 & Proteobacteria & $54 \%$ & Deltaproteobacteria & $47 \%$ & Myxococcales & $44 \%$ & Cystobacterineae & $35 \%$ & Cystobacteraceae & $34 \%$ \\
\hline BIADJ2B12 & Proteobacteria & $49 \%$ & Deltaproteobacteria & $31 \%$ & Syntrophobacterales & $26 \%$ & Syntrophobacteraceae & $25 \%$ & Desulfovirga & $12 \%$ \\
\hline BIADJ2C01 & Proteobacteria & $36 \%$ & Deltaproteobacteria & $25 \%$ & Syntrophobacterales & $15 \%$ & Syntrophobacteraceae & $15 \%$ & Desulforhabdus & $11 \%$ \\
\hline BIADJ2C02 & Firmicutes & $31 \%$ & Clostridia & $31 \%$ & Clostridiales & $27 \%$ & Lachnospiraceae & $13 \%$ & Oribacterium & $8 \%$ \\
\hline BIADJ2C03 & Chloroflexi & $38 \%$ & Chloroflexi & $37 \%$ & Chloroflexales & $37 \%$ & Chloroflexaceae & $37 \%$ & Roseiflexus & $37 \%$ \\
\hline BIADJ2C04 & Proteobacteria & $50 \%$ & Deltaproteobacteria & $42 \%$ & Myxococcales & $40 \%$ & Cystobacterineae & $40 \%$ & Cystobacteraceae & $40 \%$ \\
\hline BIADJ2C05 & Acidobacteria & $79 \%$ & Acidobacteria & $79 \%$ & Acidobacteriales & $79 \%$ & Acidobacteriaceae & $79 \%$ & Acidobacterium & $73 \%$ \\
\hline BIADJ2C06 & Proteobacteria & $32 \%$ & Deltaproteobacteria & $15 \%$ & Syntrophobacterales & $15 \%$ & Syntrophobacteraceae & $14 \%$ & Desulfovirga & $6 \%$ \\
\hline BIADJ2C07 & Proteobacteria & $100 \%$ & Alphaproteobacteria & $100 \%$ & Rhizobiales & $100 \%$ & Hyphomicrobiaceae & $62 \%$ & Rhodoplanes & $60 \%$ \\
\hline BIADJ2C08 & Firmicutes & $98 \%$ & Clostridia & $98 \%$ & Clostridiales & $97 \%$ & Acidaminococcaceae & $96 \%$ & Anaeroarcus & $63 \%$ \\
\hline BIADJ2C09 & Acidobacteria & $100 \%$ & Acidobacteria & $100 \%$ & Acidobacteriales & $100 \%$ & Acidobacteriaceae & $100 \%$ & Acidobacterium & $100 \%$ \\
\hline BIADJ2C 10 & Proteobacteria & $39 \%$ & Deltaproteobacteria & $32 \%$ & Myxococcales & $32 \%$ & Cystobacterineae & $22 \%$ & Cystobacteraceae & $20 \%$ \\
\hline BIADJ2C11 & Firmicutes & $100 \%$ & Bacilli & $100 \%$ & Bacillales & $100 \%$ & Bacillaceae & $100 \%$ & Bacillus & $100 \%$ \\
\hline BIADJ2C12 & Proteobacteria & $56 \%$ & Deltaproteobacteria & $50 \%$ & Myxococcales & $46 \%$ & Cystobacterineae & $34 \%$ & Cystobacteraceae & $32 \%$ \\
\hline BIADJ2D01 & Acidobacteria & $61 \%$ & Acidobacteria & $61 \%$ & Acidobacteriales & $61 \%$ & Acidobacteriaceae & $61 \%$ & Acidobacterium & $61 \%$ \\
\hline BIADJ2D03 & Acidobacteria & $100 \%$ & Acidobacteria & $100 \%$ & Acidobacteriales & $100 \%$ & Acidobacteriaceae & $100 \%$ & Acidobacterium & $100 \%$ \\
\hline BIADJ2D04 & Firmicutes & $100 \%$ & Bacilli & $100 \%$ & Bacillales & $100 \%$ & Alicyclobacillaceae & $100 \%$ & Alicyclobacillus & $84 \%$ \\
\hline BIADJ2D05 & Proteobacteria & $44 \%$ & Gammaproteobacteria & $17 \%$ & Chromatiales & $14 \%$ & Chromatiaceae & $12 \%$ & Thiorhodococcus & $7 \%$ \\
\hline BIADJ2D06 & Proteobacteria & $37 \%$ & Deltaproteobacteria & $22 \%$ & Myxococcales & $18 \%$ & Cystobacterineae & $11 \%$ & Cystobacteraceae & $11 \%$ \\
\hline BIADJ2D07 & Proteobacteria & $49 \%$ & Deltaproteobacteria & $42 \%$ & Syntrophobacterales & $17 \%$ & Syntrophaceae & $16 \%$ & Smithella & $15 \%$ \\
\hline BIADJ2D08 & Acidobacteria & $100 \%$ & Acidobacteria & $100 \%$ & Acidobacteriales & $100 \%$ & Acidobacteriaceae & $100 \%$ & Acidobacterium & $100 \%$ \\
\hline BIADJ2D09 & Proteobacteria & $49 \%$ & Gammaproteobacteria & $17 \%$ & Chromatiales & $14 \%$ & Ectothiorhodospiraceae & $9 \%$ & Thiorhodospira & $7 \%$ \\
\hline BIADJ2D11 & Acidobacteria & $99 \%$ & Acidobacteria & $99 \%$ & Acidobacteriales & $99 \%$ & Acidobacteriaceae & $99 \%$ & Acidobacterium & $99 \%$ \\
\hline BIADJ2D12 & Firmicutes & $55 \%$ & Clostridia & $41 \%$ & Thermoanaerobacteriales & $37 \%$ & Thermoanaerobacteriaceae & $37 \%$ & Gelria & $33 \%$ \\
\hline BIADJ2E02 & Proteobacteria & $48 \%$ & Deltaproteobacteria & $29 \%$ & Myxococcales & $23 \%$ & Cystobacterineae & $13 \%$ & Cystobacteraceae & $13 \%$ \\
\hline BIADJ2E03 & Acidobacteria & $88 \%$ & Acidobacteria & $88 \%$ & Acidobacteriales & $88 \%$ & Acidobacteriaceae & $88 \%$ & Acidobacterium & $88 \%$ \\
\hline BIADJ2E04 & Nitrospira & $94 \%$ & Nitrospira & $94 \%$ & Nitrospirales & $94 \%$ & Nitrospiraceae & $94 \%$ & Nitrospira & $94 \%$ \\
\hline BIADJ2E05 & Proteobacteria & $57 \%$ & Deltaproteobacteria & $53 \%$ & Myxococcales & $45 \%$ & Cystobacterineae & $44 \%$ & Cystobacteraceae & $44 \%$ \\
\hline BIADJ2E06 & Proteobacteria & $28 \%$ & Deltaproteobacteria & $12 \%$ & Myxococcales & $11 \%$ & Cystobacterineae & $10 \%$ & Cystobacteraceae & $10 \%$ \\
\hline BIADJ2E07 & Proteobacteria & $37 \%$ & Deltaproteobacteria & $18 \%$ & Syntrophobacterales & $10 \%$ & Syntrophobacteraceae & $10 \%$ & Thermodesulforhabdus & $5 \%$ \\
\hline
\end{tabular}


ANEXO B - Resultados das comparações das seqüências parciais da região 16S rRNA obtidas em amostras de solo Terra Preta Antropogênica e respectivos solos adjacentes da região Amazônica Central e Oriental, com as amostras depositadas no banco de dados de seqüências de 16S rRNA do RDP II pelo programa Classifier

\begin{tabular}{|c|c|c|c|c|c|c|c|c|c|c|}
\hline Clone & Filo & & Classe & & Ordem & & Família & & Gênero & \\
\hline BIADJ2E08 & Spirochaetes & $25 \%$ & Spirochaetes & $25 \%$ & Spirochaetales & $25 \%$ & Leptospiraceae & $25 \%$ & Leptonema & $25 \%$ \\
\hline BIADJ2E09 & Proteobacteria & $29 \%$ & Deltaproteobacteria & $18 \%$ & Myxococcales & $18 \%$ & Cystobacterineae & $15 \%$ & Cystobacteraceae & $15 \%$ \\
\hline BIADJ2E10 & Firmicutes & $100 \%$ & Bacilli & $100 \%$ & Bacillales & $100 \%$ & Bacillaceae & $100 \%$ & Bacillus & $100 \%$ \\
\hline BIADJ2E11 & Acidobacteria & $97 \%$ & Acidobacteria & $97 \%$ & Acidobacteriales & $97 \%$ & Acidobacteriaceae & $97 \%$ & Acidobacterium & $97 \%$ \\
\hline BIADJ2E12 & Proteobacteria & $41 \%$ & Betaproteobacteria & $29 \%$ & Burkholderiales & $28 \%$ & Alcaligenaceae & $13 \%$ & Sutterella & $13 \%$ \\
\hline BIADJ2F01 & Acidobacteria & $100 \%$ & Acidobacteria & $100 \%$ & Acidobacteriales & $100 \%$ & Acidobacteriaceae & $100 \%$ & Acidobacterium & $100 \%$ \\
\hline BIADJ2F02 & Acidobacteria & $99 \%$ & Acidobacteria & $99 \%$ & Acidobacteriales & $99 \%$ & Acidobacteriaceae & $99 \%$ & Acidobacterium & $99 \%$ \\
\hline BIADJ2F03 & Acidobacteria & $97 \%$ & Acidobacteria & $97 \%$ & Acidobacteriales & $97 \%$ & Acidobacteriaceae & $97 \%$ & Acidobacterium & $96 \%$ \\
\hline BIADJ2F05 & Proteobacteria & $91 \%$ & Deltaproteobacteria & $82 \%$ & Desulfurellales & $36 \%$ & Desulfurellaceae & $36 \%$ & Hippea & $36 \%$ \\
\hline BIADJ2F06 & Firmicutes & $50 \%$ & Clostridia & $48 \%$ & Clostridiales & $48 \%$ & Clostridiaceae & $24 \%$ & Thermobrachium & $14 \%$ \\
\hline BIADJ2F07 & Proteobacteria & $42 \%$ & Deltaproteobacteria & $30 \%$ & Myxococcales & $24 \%$ & Cystobacterineae & $18 \%$ & Cystobacteraceae & $18 \%$ \\
\hline BIADJ2F08 & Proteobacteria & $45 \%$ & Gammaproteobacteria & $20 \%$ & Chromatiales & $18 \%$ & Ectothiorhodospiraceae & $12 \%$ & Thiorhodospira & $11 \%$ \\
\hline BIADJ2F09 & Proteobacteria & $44 \%$ & Betaproteobacteria & $16 \%$ & Burkholderiales & $16 \%$ & Alcaligenaceae & $8 \%$ & Sutterella & $8 \%$ \\
\hline BIADJ2F10 & Proteobacteria & $100 \%$ & Gammaproteobacteria & $84 \%$ & Oceanospirillales & $36 \%$ & Hahellaceae & $34 \%$ & Zooshikella & $34 \%$ \\
\hline BIADJ2F11 & Acidobacteria & $63 \%$ & Acidobacteria & $63 \%$ & Acidobacteriales & $63 \%$ & Acidobacteriaceae & $63 \%$ & Acidobacterium & $59 \%$ \\
\hline BIADJ2F12 & Spirochaetes & $45 \%$ & Spirochaetes & $45 \%$ & Spirochaetales & $45 \%$ & Leptospiraceae & $45 \%$ & Leptonema & $45 \%$ \\
\hline BIADJ2G02 & Acidobacteria & $38 \%$ & Acidobacteria & $38 \%$ & Acidobacteriales & $38 \%$ & Acidobacteriaceae & $38 \%$ & Acidobacterium & $38 \%$ \\
\hline BIADJ2G03 & Proteobacteria & $100 \%$ & Alphaproteobacteria & $100 \%$ & Rhizobiales & $96 \%$ & Hyphomicrobiaceae & $74 \%$ & Filomicrobium & $59 \%$ \\
\hline BIADJ2G04 & Proteobacteria & $48 \%$ & Deltaproteobacteria & $30 \%$ & Myxococcales & $26 \%$ & Cystobacterineae & $24 \%$ & Cystobacteraceae & $24 \%$ \\
\hline BIADJ2G05 & Proteobacteria & $37 \%$ & Alphaproteobacteria & $17 \%$ & Rhodospirillales & $11 \%$ & Rhodospirillaceae & $8 \%$ & Tistrella & $8 \%$ \\
\hline BIADJ2G06 & Proteobacteria & $48 \%$ & Deltaproteobacteria & $42 \%$ & Myxococcales & $41 \%$ & Cystobacterineae & $25 \%$ & Cystobacteraceae & $24 \%$ \\
\hline BIADJ2G07 & Proteobacteria & $91 \%$ & Alphaproteobacteria & $89 \%$ & Rhizobiales & $83 \%$ & Beijerinckiaceae & $42 \%$ & Methylocapsa & $41 \%$ \\
\hline BIADJ2G08 & Proteobacteria & $40 \%$ & Deltaproteobacteria & $34 \%$ & Desulfobacterales & $13 \%$ & Desulfobulbaceae & $9 \%$ & Desulfofustis & $9 \%$ \\
\hline BIADJ2G09 & Proteobacteria & $33 \%$ & Deltaproteobacteria & $20 \%$ & Myxococcales & $19 \%$ & Cystobacterineae & $15 \%$ & Cystobacteraceae & $14 \%$ \\
\hline BIADJ2G10 & Proteobacteria & $64 \%$ & Deltaproteobacteria & $52 \%$ & Syntrophobacterales & $36 \%$ & Syntrophobacteraceae & $35 \%$ & Desulforhabdus & $22 \%$ \\
\hline BIADJ2G11 & Proteobacteria & $25 \%$ & Alphaproteobacteria & $10 \%$ & Rhodospirillales & $5 \%$ & Acetobacteraceae & $5 \%$ & Rhodopila & $2 \%$ \\
\hline BIADJ2G12 & Proteobacteria & $40 \%$ & Deltaproteobacteria & $28 \%$ & Myxococcales & $22 \%$ & Cystobacterineae & $20 \%$ & Cystobacteraceae & $20 \%$ \\
\hline BIADJ2H01 & Proteobacteria & $95 \%$ & Deltaproteobacteria & $91 \%$ & Desulfurellales & $65 \%$ & Desulfurellaceae & $65 \%$ & Hippea & $65 \%$ \\
\hline BIADJ2H02 & Firmicutes & $60 \%$ & Clostridia & $56 \%$ & Clostridiales & $55 \%$ & Lachnospiraceae & $32 \%$ & Catonella & $30 \%$ \\
\hline BIADJ2H04 & Firmicutes & $27 \%$ & Clostridia & $27 \%$ & Thermoanaerobacteriales & $13 \%$ & Thermoanaerobacteriaceae & $13 \%$ & Thermacetogenium & $11 \%$ \\
\hline BIADJ2H05 & Firmicutes & $41 \%$ & Clostridia & $30 \%$ & Clostridiales & $19 \%$ & Acidaminococcaceae & $10 \%$ & Succiniclasticum & $5 \%$ \\
\hline BIADJ2H06 & Acidobacteria & $100 \%$ & Acidobacteria & $100 \%$ & Acidobacteriales & $100 \%$ & Acidobacteriaceae & $100 \%$ & Acidobacterium & $100 \%$ \\
\hline BIADJ2H07 & Proteobacteria & $100 \%$ & Alphaproteobacteria & $100 \%$ & Rhizobiales & $96 \%$ & Hyphomicrobiaceae & $73 \%$ & Filomicrobium & $70 \%$ \\
\hline BIADJ2H08 & Chloroflexi & $31 \%$ & Chloroflexi & $31 \%$ & Chloroflexales & $31 \%$ & Chloroflexaceae & $31 \%$ & Roseiflexus & $31 \%$ \\
\hline
\end{tabular}


ANEXO B - Resultados das comparações das seqüências parciais da região 16S rRNA obtidas em amostras de solo Terra Preta Antropogênica e respectivos solos adjacentes da região Amazônica Central e Oriental, com as amostras depositadas no banco de dados de seqüências de 16S rRNA do RDP II pelo programa Classifier

\begin{tabular}{|c|c|c|c|c|c|c|c|c|c|c|}
\hline Clone & Filo & & Classe & & Ordem & & Família & & Gênero & shons \\
\hline BIADJ2H09 & Acidobacteria & $99 \%$ & Acidobacteria & $99 \%$ & Acidobacteriales & $99 \%$ & Acidobacteriaceae & $99 \%$ & Acidobacterium & $96 \%$ \\
\hline BIADJ2H10 & Proteobacteria & $100 \%$ & Alphaproteobacteria & $100 \%$ & Rhizobiales & $100 \%$ & Hyphomicrobiaceae & $70 \%$ & Rhodoplanes & $65 \%$ \\
\hline BIADJ2H11 & Thermomicrobia & $55 \%$ & Thermomicrobia & $55 \%$ & Thermomicrobiales & $55 \%$ & Thermomicrobiaceae & $55 \%$ & Thermomicrobium & $55 \%$ \\
\hline BIADJ3A01 & Acidobacteria & $100 \%$ & Acidobacteria & $100 \%$ & Acidobacteriales & $100 \%$ & Acidobacteriaceae & $100 \%$ & Acidobacterium & $100 \%$ \\
\hline BIADJ3A02 & Acidobacteria & $45 \%$ & Acidobacteria & $45 \%$ & Acidobacteriales & $45 \%$ & Acidobacteriaceae & $45 \%$ & Acidobacterium & $45 \%$ \\
\hline BIADJ3A03 & Acidobacteria & $63 \%$ & Acidobacteria & $63 \%$ & Acidobacteriales & $63 \%$ & Acidobacteriaceae & $63 \%$ & Acidobacterium & $63 \%$ \\
\hline BIADJ3A04 & Acidobacteria & $65 \%$ & Acidobacteria & $65 \%$ & Acidobacteriales & $65 \%$ & Acidobacteriaceae & $65 \%$ & Acidobacterium & $64 \%$ \\
\hline BIADJ3A05 & Proteobacteria & $98 \%$ & Alphaproteobacteria & $98 \%$ & Rhodospirillales & $80 \%$ & Acetobacteraceae & $47 \%$ & Stella & $46 \%$ \\
\hline BIADJ3A06 & Proteobacteria & $50 \%$ & Deltaproteobacteria & $45 \%$ & Desulfuromonales & $20 \%$ & Desulfuromonaceae & $19 \%$ & Malonomonas & $19 \%$ \\
\hline BIADJ3A07 & Proteobacteria & $52 \%$ & Deltaproteobacteria & $44 \%$ & Syntrophobacterales & $35 \%$ & Syntrophobacteraceae & $28 \%$ & Desulfovirga & $23 \%$ \\
\hline BIADJ3A08 & Acidobacteria & $92 \%$ & Acidobacteria & $92 \%$ & Acidobacteriales & $92 \%$ & Acidobacteriaceae & $92 \%$ & Acidobacterium & $92 \%$ \\
\hline BIADJ3A09 & Acidobacteria & $61 \%$ & Acidobacteria & $61 \%$ & Acidobacteriales & $61 \%$ & Acidobacteriaceae & $61 \%$ & Acidobacterium & $58 \%$ \\
\hline BIADJ3A10 & Proteobacteria & $99 \%$ & Alphaproteobacteria & $99 \%$ & Rhodospirillales & $83 \%$ & Acetobacteraceae & $44 \%$ & Stella & $44 \%$ \\
\hline BIADJ3A12 & Verrucomicrobia & $31 \%$ & Verrucomicrobiae & $31 \%$ & Verrucomicrobiales & $31 \%$ & Opitutaceae & $30 \%$ & Opitutus & $30 \%$ \\
\hline BIADJ3B01 & Proteobacteria & $38 \%$ & Deltaproteobacteria & $31 \%$ & Syntrophobacterales & $22 \%$ & Syntrophobacteraceae & $21 \%$ & Desulforhabdus & $10 \%$ \\
\hline BIADJ3B02 & Actinobacteria & $34 \%$ & Actinobacteria & $34 \%$ & Rubrobacteridae & $26 \%$ & Rubrobacterales & $26 \%$ & Rubrobacterineae & $26 \%$ \\
\hline BIADJ3B03 & Firmicutes & $35 \%$ & Clostridia & $35 \%$ & Clostridiales & $28 \%$ & Clostridiaceae & $16 \%$ & Faecalibacterium & $10 \%$ \\
\hline BIADJ3B04 & Proteobacteria & $30 \%$ & Deltaproteobacteria & $18 \%$ & Myxococcales & $14 \%$ & Cystobacterineae & $9 \%$ & Cystobacteraceae & $8 \%$ \\
\hline BIADJ3B05 & Acidobacteria & $98 \%$ & Acidobacteria & $98 \%$ & Acidobacteriales & $98 \%$ & Acidobacteriaceae & $98 \%$ & Acidobacterium & $98 \%$ \\
\hline BIADJ3B06 & Proteobacteria & $52 \%$ & Deltaproteobacteria & $43 \%$ & Myxococcales & $37 \%$ & Nannocystineae & $27 \%$ & Nannocystaceae & $27 \%$ \\
\hline BIADJ3B07 & Proteobacteria & $53 \%$ & Deltaproteobacteria & $41 \%$ & Syntrophobacterales & $20 \%$ & Syntrophobacteraceae & $19 \%$ & Desulforhabdus & $9 \%$ \\
\hline BIADJ3B08 & Proteobacteria & $45 \%$ & Deltaproteobacteria & $30 \%$ & Syntrophobacterales & $26 \%$ & Syntrophobacteraceae & $26 \%$ & Desulfovirga & $22 \%$ \\
\hline BIADJ3B09 & Firmicutes & $42 \%$ & Clostridia & $41 \%$ & Clostridiales & $28 \%$ & Acidaminococcaceae & $10 \%$ & Centipeda & $6 \%$ \\
\hline BIADJ3B10 & Acidobacteria & $100 \%$ & Acidobacteria & $100 \%$ & Acidobacteriales & $100 \%$ & Acidobacteriaceae & $100 \%$ & Acidobacterium & $100 \%$ \\
\hline BIADJ3B11 & Acidobacteria & $98 \%$ & Acidobacteria & $98 \%$ & Acidobacteriales & $98 \%$ & Acidobacteriaceae & $98 \%$ & Acidobacterium & $98 \%$ \\
\hline BIADJ3B12 & Acidobacteria & $99 \%$ & Acidobacteria & $99 \%$ & Acidobacteriales & $99 \%$ & Acidobacteriaceae & $99 \%$ & Acidobacterium & $99 \%$ \\
\hline BIADJ3C01 & Proteobacteria & $40 \%$ & Deltaproteobacteria & $29 \%$ & Myxococcales & $12 \%$ & Cystobacterineae & $11 \%$ & Cystobacteraceae & $11 \%$ \\
\hline BIADJ3C02 & Acidobacteria & $48 \%$ & Acidobacteria & $48 \%$ & Acidobacteriales & $48 \%$ & Acidobacteriaceae & $48 \%$ & Acidobacterium & $48 \%$ \\
\hline BIADJ3C03 & Firmicutes & $30 \%$ & Clostridia & $29 \%$ & Clostridiales & $23 \%$ & Clostridiaceae & $11 \%$ & Faecalibacterium & $6 \%$ \\
\hline BIADJ3C04 & Proteobacteria & $100 \%$ & Alphaproteobacteria & $100 \%$ & Rhizobiales & $100 \%$ & Beijerinckiaceae & $95 \%$ & Methylocapsa & $71 \%$ \\
\hline BIADJ3C05 & Acidobacteria & $50 \%$ & Acidobacteria & $50 \%$ & Acidobacteriales & $50 \%$ & Acidobacteriaceae & $50 \%$ & Acidobacterium & $44 \%$ \\
\hline BIADJ3C06 & Firmicutes & $51 \%$ & Clostridia & $51 \%$ & Clostridiales & $50 \%$ & Lachnospiraceae & $26 \%$ & Catonella & $24 \%$ \\
\hline BIADJ3C07 & Acidobacteria & $45 \%$ & Acidobacteria & $45 \%$ & Acidobacteriales & $45 \%$ & Acidobacteriaceae & $45 \%$ & Acidobacterium & $45 \%$ \\
\hline
\end{tabular}


ANEXO B - Resultados das comparações das seqüências parciais da região 16S rRNA obtidas em amostras de solo Terra Preta Antropogênica e respectivos solos adjacentes da região Amazônica Central e Oriental, com as amostras depositadas no banco de dados de seqüências de 16S rRNA do RDP II pelo programa Classifier

\begin{tabular}{|c|c|c|c|c|c|c|c|c|c|c|}
\hline Clone & Filo & & Classe & & Ordem & & Família & & Gênero & 3 \\
\hline BIADJ3C08 & Acidobacteria & $100 \%$ & Acidobacteria & $100 \%$ & Acidobacteriales & $100 \%$ & Acidobacteriaceae & $100 \%$ & Acidobacterium & $100 \%$ \\
\hline BIADJ3C09 & Proteobacteria & $100 \%$ & Alphaproteobacteria & $100 \%$ & Rhizobiales & $91 \%$ & Hyphomicrobiaceae & $81 \%$ & Filomicrobium & $75 \%$ \\
\hline BIADJ3C11 & Proteobacteria & $40 \%$ & Deltaproteobacteria & $32 \%$ & Myxococcales & $30 \%$ & Cystobacterineae & $30 \%$ & Cystobacteraceae & $28 \%$ \\
\hline BIADJ3C12 & Proteobacteria & $50 \%$ & Deltaproteobacteria & $40 \%$ & Syntrophobacterales & $32 \%$ & Syntrophobacteraceae & $32 \%$ & Desulforhabdus & $22 \%$ \\
\hline BIADJ3D01 & Proteobacteria & $47 \%$ & Deltaproteobacteria & $40 \%$ & Myxococcales & $28 \%$ & Cystobacterineae & $18 \%$ & Cystobacteraceae & $18 \%$ \\
\hline BIADJ3D02 & Acidobacteria & $100 \%$ & Acidobacteria & $100 \%$ & Acidobacteriales & $100 \%$ & Acidobacteriaceae & $100 \%$ & Acidobacterium & $100 \%$ \\
\hline BIADJ3D04 & Acidobacteria & $97 \%$ & Acidobacteria & $97 \%$ & Acidobacteriales & $97 \%$ & Acidobacteriaceae & $97 \%$ & Acidobacterium & $94 \%$ \\
\hline BIADJ3D05 & Acidobacteria & $49 \%$ & Acidobacteria & $49 \%$ & Acidobacteriales & $49 \%$ & Acidobacteriaceae & $49 \%$ & Acidobacterium & $48 \%$ \\
\hline BIADJ3D06 & Acidobacteria & $61 \%$ & Acidobacteria & $61 \%$ & Acidobacteriales & $61 \%$ & Acidobacteriaceae & $61 \%$ & Acidobacterium & $50 \%$ \\
\hline BIADJ3D07 & Acidobacteria & $100 \%$ & Acidobacteria & $100 \%$ & Acidobacteriales & $100 \%$ & Acidobacteriaceae & $100 \%$ & Acidobacterium & $100 \%$ \\
\hline BIADJ3D08 & Proteobacteria & $52 \%$ & Deltaproteobacteria & $35 \%$ & Syntrophobacterales & $23 \%$ & Syntrophobacteraceae & $19 \%$ & Desulfovirga & $10 \%$ \\
\hline BIADJ3D11 & Acidobacteria & $59 \%$ & Acidobacteria & $59 \%$ & Acidobacteriales & $59 \%$ & Acidobacteriaceae & $59 \%$ & Acidobacterium & $54 \%$ \\
\hline BIADJ3D12 & Proteobacteria & $54 \%$ & Deltaproteobacteria & $44 \%$ & Desulfovibrionales & $18 \%$ & Desulfovibrionaceae & $17 \%$ & Lawsonia & $17 \%$ \\
\hline BIADJ3E01 & Proteobacteria & $39 \%$ & Deltaproteobacteria & $27 \%$ & Myxococcales & $22 \%$ & Cystobacterineae & $14 \%$ & Cystobacteraceae & $14 \%$ \\
\hline BIADJ3E02 & Acidobacteria & $100 \%$ & Acidobacteria & $100 \%$ & Acidobacteriales & $100 \%$ & Acidobacteriaceae & $100 \%$ & Acidobacterium & $99 \%$ \\
\hline BIADJ3E03 & Acidobacteria & $100 \%$ & Acidobacteria & $100 \%$ & Acidobacteriales & $100 \%$ & Acidobacteriaceae & $100 \%$ & Acidobacterium & $99 \%$ \\
\hline BIADJ3E04 & Proteobacteria & $35 \%$ & Deltaproteobacteria & $30 \%$ & Myxococcales & $22 \%$ & Cystobacterineae & $22 \%$ & Cystobacteraceae & $22 \%$ \\
\hline BIADJ3E05 & Acidobacteria & $36 \%$ & Acidobacteria & $36 \%$ & Acidobacteriales & $36 \%$ & Acidobacteriaceae & $36 \%$ & Acidobacterium & $36 \%$ \\
\hline BIADJ3E06 & Proteobacteria & $59 \%$ & Deltaproteobacteria & $49 \%$ & Syntrophobacterales & $34 \%$ & Syntrophobacteraceae & $33 \%$ & Desulforhabdus & $22 \%$ \\
\hline BIADJ3E07 & Proteobacteria & $43 \%$ & Deltaproteobacteria & $32 \%$ & Syntrophobacterales & $26 \%$ & Syntrophobacteraceae & $25 \%$ & Desulforhabdus & $18 \%$ \\
\hline BIADJ3E08 & Proteobacteria & $46 \%$ & Deltaproteobacteria & $44 \%$ & Myxococcales & $41 \%$ & Cystobacterineae & $41 \%$ & Cystobacteraceae & $41 \%$ \\
\hline BIADJ3E09 & Proteobacteria & $44 \%$ & Deltaproteobacteria & $19 \%$ & Myxococcales & $15 \%$ & Cystobacterineae & $14 \%$ & Cystobacteraceae & $14 \%$ \\
\hline BIADJ3E10 & Firmicutes & $54 \%$ & Clostridia & $53 \%$ & Clostridiales & $53 \%$ & Lachnospiraceae & $24 \%$ & Catonella & $21 \%$ \\
\hline BIADJ3E11 & Firmicutes & $35 \%$ & Clostridia & $34 \%$ & Clostridiales & $31 \%$ & Clostridiaceae & $17 \%$ & Faecalibacterium & $7 \%$ \\
\hline BIADJ3E12 & Proteobacteria & $51 \%$ & Deltaproteobacteria & $39 \%$ & Syntrophobacterales & $33 \%$ & Syntrophobacteraceae & $31 \%$ & Desulforhabdus & $22 \%$ \\
\hline BIADJ3F01 & Acidobacteria & $100 \%$ & Acidobacteria & $100 \%$ & Acidobacteriales & $100 \%$ & Acidobacteriaceae & $100 \%$ & Acidobacterium & $100 \%$ \\
\hline BIADJ3F02 & Proteobacteria & $38 \%$ & Deltaproteobacteria & $28 \%$ & Myxococcales & $10 \%$ & Cystobacterineae & $7 \%$ & Cystobacteraceae & $7 \%$ \\
\hline BIADJ3F03 & Proteobacteria & $38 \%$ & Deltaproteobacteria & $27 \%$ & Syntrophobacterales & $16 \%$ & Syntrophobacteraceae & $16 \%$ & Desulforhabdus & $9 \%$ \\
\hline BIADJ3F04 & Chloroflexi & $40 \%$ & Anaerolineae & $38 \%$ & Anaerolinaeles & $38 \%$ & Anaerolinaeceea & $38 \%$ & Anaerolinea & $38 \%$ \\
\hline BIADJ3F05 & Acidobacteria & $43 \%$ & Acidobacteria & $43 \%$ & Acidobacteriales & $43 \%$ & Acidobacteriaceae & $43 \%$ & Acidobacterium & $42 \%$ \\
\hline BIADJ3F06 & Acidobacteria & $99 \%$ & Acidobacteria & $99 \%$ & Acidobacteriales & $99 \%$ & Acidobacteriaceae & $99 \%$ & Acidobacterium & $99 \%$ \\
\hline BIADJ3F07 & Proteobacteria & $39 \%$ & Deltaproteobacteria & $35 \%$ & Syntrophobacterales & $27 \%$ & Syntrophobacteraceae & $25 \%$ & Desulforhabdus & $14 \%$ \\
\hline BIADJ3F08 & Acidobacteria & $100 \%$ & Acidobacteria & $100 \%$ & Acidobacteriales & $100 \%$ & Acidobacteriaceae & $100 \%$ & Acidobacterium & $99 \%$ \\
\hline BIADJ3F 10 & Acidobacteria & $100 \%$ & Acidobacteria & $100 \%$ & Acidobacteriales & $100 \%$ & Acidobacteriaceae & $100 \%$ & Acidobacterium & $100 \%$ \\
\hline
\end{tabular}


ANEXO B - Resultados das comparações das seqüências parciais da região 16S rRNA obtidas em amostras de solo Terra Preta Antropogênica e respectivos solos adjacentes da região Amazônica Central e Oriental, com as amostras depositadas no banco de dados de seqüências de 16S rRNA do RDP II pelo programa Classifier

\begin{tabular}{|c|c|c|c|c|c|c|c|c|c|c|}
\hline Clone & Filo & & Classe & & Ordem & & Família & & Gênero & \\
\hline BIADJ3F12 & Proteobacteria & $64 \%$ & Deltaproteobacteria & $55 \%$ & Syntrophobacterales & $41 \%$ & Syntrophobacteraceae & $41 \%$ & Desulfovirga & $34 \%$ \\
\hline BIADJ3G01 & Firmicutes & $22 \%$ & Clostridia & $21 \%$ & Thermoanaerobacteriales & $12 \%$ & Thermoanaerobacteriaceae & $9 \%$ & Gelria & $8 \%$ \\
\hline BIADJ3G02 & Acidobacteria & $43 \%$ & Acidobacteria & $43 \%$ & Acidobacteriales & $43 \%$ & Acidobacteriaceae & $43 \%$ & Acidobacterium & $43 \%$ \\
\hline BIADJ3G03 & Thermomicrobia & $60 \%$ & Thermomicrobia & $60 \%$ & Thermomicrobiales & $60 \%$ & Thermomicrobiaceae & $60 \%$ & Thermomicrobium & $60 \%$ \\
\hline BIADJ3G04 & Acidobacteria & $52 \%$ & Acidobacteria & $52 \%$ & Acidobacteriales & $52 \%$ & Acidobacteriaceae & $52 \%$ & Acidobacterium & $48 \%$ \\
\hline BIADJ3G06 & Firmicutes & $36 \%$ & Clostridia & $35 \%$ & Clostridiales & $30 \%$ & Acidaminococcaceae & $11 \%$ & Allisonella & $8 \%$ \\
\hline BIADJ3G07 & Actinobacteria & $25 \%$ & Actinobacteria & $25 \%$ & Rubrobacteridae & $21 \%$ & Rubrobacterales & $21 \%$ & Rubrobacterineae & $21 \%$ \\
\hline BIADJ3G08 & Actinobacteria & $25 \%$ & Actinobacteria & $25 \%$ & Rubrobacteridae & $19 \%$ & Rubrobacterales & $19 \%$ & Rubrobacterineae & $19 \%$ \\
\hline BIADJ3G10 & Acidobacteria & $47 \%$ & Acidobacteria & $47 \%$ & Acidobacteriales & $47 \%$ & Acidobacteriaceae & $47 \%$ & Acidobacterium & $45 \%$ \\
\hline BIADJ3G11 & Acidobacteria & $69 \%$ & Acidobacteria & $69 \%$ & Acidobacteriales & $69 \%$ & Acidobacteriaceae & $69 \%$ & Acidobacterium & $67 \%$ \\
\hline BIADJ3G12 & Proteobacteria & $42 \%$ & Gammaproteobacteria & $17 \%$ & Chromatiales & $15 \%$ & Ectothiorhodospiraceae & $15 \%$ & Alkalispirillum & $7 \%$ \\
\hline BIADJ3H01 & Proteobacteria & $55 \%$ & Deltaproteobacteria & $42 \%$ & Syntrophobacterales & $20 \%$ & Syntrophobacteraceae & $18 \%$ & Desulforhabdus & $8 \%$ \\
\hline BIADJ3H02 & Chloroflexi & $38 \%$ & Anaerolineae & $36 \%$ & Anaerolinaeles & $36 \%$ & Anaerolinaeceea & $36 \%$ & Anaerolinea & $36 \%$ \\
\hline BIADJ3H03 & Firmicutes & $32 \%$ & Clostridia & $31 \%$ & Clostridiales & $25 \%$ & Clostridiaceae & $15 \%$ & Faecalibacterium & $7 \%$ \\
\hline BIADJ3H04 & Proteobacteria & $44 \%$ & Deltaproteobacteria & $36 \%$ & Syntrophobacterales & $25 \%$ & Syntrophobacteraceae & $25 \%$ & Desulforhabdus & $16 \%$ \\
\hline BIADJ3H05 & Acidobacteria & $64 \%$ & Acidobacteria & $64 \%$ & Acidobacteriales & $64 \%$ & Acidobacteriaceae & $64 \%$ & Acidobacterium & $60 \%$ \\
\hline BIADJ3H06 & Acidobacteria & $34 \%$ & Acidobacteria & $34 \%$ & Acidobacteriales & $34 \%$ & Acidobacteriaceae & $34 \%$ & Acidobacterium & $33 \%$ \\
\hline BIADJ3H08 & Proteobacteria & $41 \%$ & Deltaproteobacteria & $16 \%$ & Myxococcales & $15 \%$ & Nannocystineae & $10 \%$ & Nannocystaceae & $10 \%$ \\
\hline BIADJ3H09 & Proteobacteria & $39 \%$ & Deltaproteobacteria & $24 \%$ & Syntrophobacterales & $12 \%$ & Syntrophobacteraceae & $11 \%$ & Desulfovirga & $7 \%$ \\
\hline BIADJ3H10 & Acidobacteria & $53 \%$ & Acidobacteria & $53 \%$ & Acidobacteriales & $53 \%$ & Acidobacteriaceae & $53 \%$ & Acidobacterium & $52 \%$ \\
\hline BIADJ3H11 & Acidobacteria & $30 \%$ & Acidobacteria & $30 \%$ & Acidobacteriales & $30 \%$ & Acidobacteriaceae & $30 \%$ & Acidobacterium & $30 \%$ \\
\hline MITPA1A01 & Acidobacteria & $40 \%$ & Acidobacteria & $40 \%$ & Acidobacteriales & $40 \%$ & Acidobacteriaceae & $40 \%$ & Geothrix & $15 \%$ \\
\hline MITPA1A02 & Firmicutes & $49 \%$ & Clostridia & $46 \%$ & Clostridiales & $29 \%$ & Acidaminococcaceae & $18 \%$ & Acetonema & $7 \%$ \\
\hline MITPA1A03 & Acidobacteria & $59 \%$ & Acidobacteria & $59 \%$ & Acidobacteriales & $59 \%$ & Acidobacteriaceae & $59 \%$ & Holophaga & $42 \%$ \\
\hline MITPA1A04 & Acidobacteria & $73 \%$ & Acidobacteria & $73 \%$ & Acidobacteriales & $73 \%$ & Acidobacteriaceae & $73 \%$ & Holophaga & $70 \%$ \\
\hline MITPA1A05 & Acidobacteria & $37 \%$ & Acidobacteria & $37 \%$ & Acidobacteriales & $37 \%$ & Acidobacteriaceae & $37 \%$ & Acidobacterium & $36 \%$ \\
\hline MITPA1A06 & Proteobacteria & $58 \%$ & Betaproteobacteria & $30 \%$ & Burkholderiales & $24 \%$ & Comamonadaceae & $11 \%$ & Hylemonella & $4 \%$ \\
\hline MITPA1A07 & Firmicutes & $63 \%$ & Clostridia & $57 \%$ & Thermoanaerobacteriales & $37 \%$ & Thermoanaerobacteriaceae & $37 \%$ & Thermanaeromonas & $19 \%$ \\
\hline MITPA1A08 & Proteobacteria & $82 \%$ & Deltaproteobacteria & $73 \%$ & Myxococcales & $26 \%$ & Cystobacterineae & $23 \%$ & Cystobacteraceae & $23 \%$ \\
\hline MITPA1A09 & Proteobacteria & $62 \%$ & Deltaproteobacteria & $23 \%$ & Desulfovibrionales & $6 \%$ & Desulfohalobiaceae & $6 \%$ & Desulfothermus & $5 \%$ \\
\hline MITPA1A10 & Proteobacteria & $53 \%$ & Deltaproteobacteria & $22 \%$ & Syntrophobacterales & $7 \%$ & Syntrophaceae & $4 \%$ & Smithella & $2 \%$ \\
\hline MITPA1A11 & Proteobacteria & $45 \%$ & Alphaproteobacteria & $20 \%$ & Rhodospirillales & $16 \%$ & Rhodospirillaceae & $14 \%$ & Inquilinus & $12 \%$ \\
\hline MITPA1A12 & Proteobacteria & $32 \%$ & Alphaproteobacteria & $26 \%$ & Rhodospirillales & $23 \%$ & Rhodospirillaceae & $14 \%$ & Inquilinus & $14 \%$ \\
\hline MITPA1B01 & Acidobacteria & $52 \%$ & Acidobacteria & $52 \%$ & Acidobacteriales & $52 \%$ & Acidobacteriaceae & $52 \%$ & Acidobacterium & $42 \%$ \\
\hline
\end{tabular}


ANEXO B - Resultados das comparações das seqüências parciais da região 16S rRNA obtidas em amostras de solo Terra Preta Antropogênica e respectivos solos adjacentes da região Amazônica Central e Oriental, com as amostras depositadas no banco de dados de seqüências de 16S rRNA do RDP II pelo programa Classifier

\begin{tabular}{|c|c|c|c|c|c|c|c|c|c|c|}
\hline Clone & Filo & & Classe & & Ordem & & Família & & Gênero & \\
\hline MITPA1B02 & Proteobacteria & $64 \%$ & Betaproteobacteria & $25 \%$ & Burkholderiales & $25 \%$ & Comamonadaceae & $25 \%$ & Caldimonas & $19 \%$ \\
\hline MITPA1B03 & Proteobacteria & $48 \%$ & Gammaproteobacteria & $26 \%$ & Chromatiales & $13 \%$ & Chromatiaceae & $11 \%$ & Thiorhodococcus & $4 \%$ \\
\hline MITPA1B04 & Proteobacteria & $50 \%$ & Deltaproteobacteria & $19 \%$ & Desulfobacterales & $6 \%$ & Desulfobacteraceae & $6 \%$ & Desulforegula & $3 \%$ \\
\hline MITPA1B05 & Proteobacteria & $43 \%$ & Alphaproteobacteria & $16 \%$ & Rhodospirillales & $9 \%$ & Acetobacteraceae & $6 \%$ & Craurococcus & $4 \%$ \\
\hline MITPA1B06 & Proteobacteria & $41 \%$ & Alphaproteobacteria & $23 \%$ & Rhodospirillales & $19 \%$ & Acetobacteraceae & $19 \%$ & Craurococcus & $18 \%$ \\
\hline MITPA1B07 & Acidobacteria & $98 \%$ & Acidobacteria & $98 \%$ & Acidobacteriales & $98 \%$ & Acidobacteriaceae & $98 \%$ & Acidobacterium & $98 \%$ \\
\hline MITPA1B08 & Proteobacteria & $61 \%$ & Deltaproteobacteria & $37 \%$ & Desulfobacterales & $15 \%$ & Desulfobacteraceae & $13 \%$ & Desulforegula & $9 \%$ \\
\hline MITPA1B09 & Acidobacteria & $37 \%$ & Acidobacteria & $37 \%$ & Acidobacteriales & $37 \%$ & Acidobacteriaceae & $37 \%$ & Holophaga & $33 \%$ \\
\hline MITPA1B10 & Proteobacteria & $48 \%$ & Deltaproteobacteria & $34 \%$ & Bdellovibrionales & $14 \%$ & Bacteriovoracaceae & $13 \%$ & Peredibacter & $13 \%$ \\
\hline MITPA1B11 & Firmicutes & $38 \%$ & Clostridia & $38 \%$ & Clostridiales & $30 \%$ & Acidaminococcaceae & $18 \%$ & Allisonella & $12 \%$ \\
\hline MITPA1B12 & Proteobacteria & $35 \%$ & Deltaproteobacteria & $13 \%$ & Desulfuromonales & $3 \%$ & Desulfuromonaceae & $3 \%$ & Malonomonas & $3 \%$ \\
\hline MITPA1C01 & Proteobacteria & $100 \%$ & Alphaproteobacteria & $100 \%$ & Rhizobiales & $97 \%$ & Hyphomicrobiaceae & $93 \%$ & Pedomicrobium & $71 \%$ \\
\hline MITPA1C02 & Firmicutes & $56 \%$ & Clostridia & $56 \%$ & Thermoanaerobacteriales & $36 \%$ & Thermoanaerobacteriaceae & $36 \%$ & Gelria & $34 \%$ \\
\hline MITPA1C03 & Proteobacteria & $56 \%$ & Deltaproteobacteria & $27 \%$ & Desulfovibrionales & $9 \%$ & Desulfohalobiaceae & $6 \%$ & Desulfothermus & $4 \%$ \\
\hline MITPA1C04 & Acidobacteria & $58 \%$ & Acidobacteria & $58 \%$ & Acidobacteriales & $58 \%$ & Acidobacteriaceae & $58 \%$ & Holophaga & $58 \%$ \\
\hline MITPA1C05 & Proteobacteria & $88 \%$ & Deltaproteobacteria & $87 \%$ & Syntrophobacterales & $77 \%$ & Syntrophobacteraceae & $66 \%$ & Desulfovirga & $54 \%$ \\
\hline MITPA1C06 & Proteobacteria & $76 \%$ & Deltaproteobacteria & $61 \%$ & Syntrophobacterales & $31 \%$ & Syntrophobacteraceae & $26 \%$ & Desulforhabdus & $14 \%$ \\
\hline MITPA1C07 & Proteobacteria & $43 \%$ & Deltaproteobacteria & $27 \%$ & Desulfobacterales & $12 \%$ & Desulfobulbaceae & $11 \%$ & Desulfofustis & $11 \%$ \\
\hline MITPA1C08 & Acidobacteria & $39 \%$ & Acidobacteria & $39 \%$ & Acidobacteriales & $39 \%$ & Acidobacteriaceae & $39 \%$ & Acidobacterium & $39 \%$ \\
\hline MITPA1C09 & Acidobacteria & $41 \%$ & Acidobacteria & $41 \%$ & Acidobacteriales & $41 \%$ & Acidobacteriaceae & $41 \%$ & Acidobacterium & $36 \%$ \\
\hline MITPA1C11 & Acidobacteria & $45 \%$ & Acidobacteria & $45 \%$ & Acidobacteriales & $45 \%$ & Acidobacteriaceae & $45 \%$ & Holophaga & $41 \%$ \\
\hline MITPA1C12 & Firmicutes & $61 \%$ & Clostridia & $60 \%$ & Thermoanaerobacteriales & $33 \%$ & Thermoanaerobacteriaceae & $33 \%$ & Gelria & $32 \%$ \\
\hline MITPA1D01 & Proteobacteria & $100 \%$ & Betaproteobacteria & $100 \%$ & Burkholderiales & $96 \%$ & Comamonadaceae & $95 \%$ & Ramlibacter & $78 \%$ \\
\hline MITPA1D02 & Firmicutes & $60 \%$ & Clostridia & $56 \%$ & Thermoanaerobacteriales & $37 \%$ & Thermoanaerobacteriaceae & $37 \%$ & Thermanaeromonas & $19 \%$ \\
\hline MITPA1D03 & Proteobacteria & $100 \%$ & Alphaproteobacteria & $100 \%$ & Rhizobiales & $97 \%$ & Hyphomicrobiaceae & $88 \%$ & Pedomicrobium & $65 \%$ \\
\hline MITPA1D04 & Acidobacteria & $83 \%$ & Acidobacteria & $83 \%$ & Acidobacteriales & $83 \%$ & Acidobacteriaceae & $83 \%$ & Acidobacterium & $80 \%$ \\
\hline MITPA1D05 & Proteobacteria & $45 \%$ & Deltaproteobacteria & $18 \%$ & Desulfobacterales & $6 \%$ & Desulfobulbaceae & $5 \%$ & Desulfofustis & $5 \%$ \\
\hline MITPA1D06 & Acidobacteria & $49 \%$ & Acidobacteria & $49 \%$ & Acidobacteriales & $49 \%$ & Acidobacteriaceae & $49 \%$ & Acidobacterium & $45 \%$ \\
\hline MITPA1D07 & Firmicutes & $26 \%$ & Clostridia & $24 \%$ & Clostridiales & $15 \%$ & Acidaminococcaceae & $9 \%$ & Anaerovibrio & $3 \%$ \\
\hline MITPA1D08 & Proteobacteria & $44 \%$ & Deltaproteobacteria & $17 \%$ & Desulfuromonales & $6 \%$ & Desulfuromonaceae & $6 \%$ & Malonomonas & $6 \%$ \\
\hline MITPA1D09 & Acidobacteria & $40 \%$ & Acidobacteria & $40 \%$ & Acidobacteriales & $40 \%$ & Acidobacteriaceae & $40 \%$ & Holophaga & $17 \%$ \\
\hline MITPA1D10 & Acidobacteria & $74 \%$ & Acidobacteria & $74 \%$ & Acidobacteriales & $74 \%$ & Acidobacteriaceae & $74 \%$ & Acidobacterium & $70 \%$ \\
\hline MITPA1D11 & Proteobacteria & $84 \%$ & Deltaproteobacteria & $41 \%$ & Myxococcales & $34 \%$ & Cystobacterineae & $34 \%$ & Cystobacteraceae & $33 \%$ \\
\hline MITPA1D12 & Firmicutes & $100 \%$ & Bacilli & $100 \%$ & Bacillales & $100 \%$ & Paenibacillaceae & $100 \%$ & Paenibacillus & $100 \%$ \\
\hline
\end{tabular}


ANEXO B - Resultados das comparações das seqüências parciais da região 16S rRNA obtidas em amostras de solo Terra Preta Antropogênica e respectivos solos adjacentes da região Amazônica Central e Oriental, com as amostras depositadas no banco de dados de seqüências de 16S rRNA do RDP II pelo programa Classifier

\begin{tabular}{|c|c|c|c|c|c|c|c|c|c|c|}
\hline Clone & Filo & & Classe & & Ordem & & Família & & Gênero & \\
\hline MITPA1E01 & Proteobacteria & $48 \%$ & Deltaproteobacteria & $46 \%$ & Syntrophobacterales & $20 \%$ & Syntrophobacteraceae & $20 \%$ & Desulfovirga & $11 \%$ \\
\hline MITPA1E02 & Firmicutes & $100 \%$ & Bacilli & $100 \%$ & Bacillales & $96 \%$ & Paenibacillaceae & $80 \%$ & Thermobacillus & $40 \%$ \\
\hline MITPA1E03 & Proteobacteria & $97 \%$ & Deltaproteobacteria & $96 \%$ & Desulfuromonales & $48 \%$ & Geobacteraceae & $39 \%$ & Trichlorobacter & $39 \%$ \\
\hline MITPA1E04 & Acidobacteria & $74 \%$ & Acidobacteria & $74 \%$ & Acidobacteriales & $74 \%$ & Acidobacteriaceae & $74 \%$ & Holophaga & $64 \%$ \\
\hline MITPA1E05 & Acidobacteria & $36 \%$ & Acidobacteria & $36 \%$ & Acidobacteriales & $36 \%$ & Acidobacteriaceae & $36 \%$ & Holophaga & $35 \%$ \\
\hline MITPA1E06 & Proteobacteria & $45 \%$ & Deltaproteobacteria & $37 \%$ & Bdellovibrionales & $20 \%$ & Bacteriovoracaceae & $20 \%$ & Peredibacter & $20 \%$ \\
\hline MITPA1E07 & Firmicutes & $74 \%$ & Clostridia & $74 \%$ & Thermoanaerobacteriales & $73 \%$ & Thermodesulfobiaceae & $73 \%$ & Thermodesulfobium & $73 \%$ \\
\hline MITPA1E08 & Genera_incertae_sedis_WS3 & $100 \%$ & WS3 & $100 \%$ & & & & & & \\
\hline MITPA1E10 & Acidobacteria & $39 \%$ & Acidobacteria & $39 \%$ & Acidobacteriales & $39 \%$ & Acidobacteriaceae & $39 \%$ & Acidobacterium & $24 \%$ \\
\hline MITPA1E11 & Proteobacteria & $79 \%$ & Deltaproteobacteria & $76 \%$ & Syntrophobacterales & $43 \%$ & Syntrophobacteraceae & $40 \%$ & Desulfovirga & $38 \%$ \\
\hline MITPA1E12 & Acidobacteria & $61 \%$ & Acidobacteria & $61 \%$ & Acidobacteriales & $61 \%$ & Acidobacteriaceae & $61 \%$ & Holophaga & $48 \%$ \\
\hline MITPA1F01 & Firmicutes & $38 \%$ & Clostridia & $38 \%$ & Clostridiales & $25 \%$ & Clostridiaceae & $12 \%$ & Oxobacter & $4 \%$ \\
\hline MITPA1F02 & Proteobacteria & $97 \%$ & Deltaproteobacteria & $96 \%$ & Desulfuromonales & $41 \%$ & Geobacteraceae & $36 \%$ & Trichlorobacter & $36 \%$ \\
\hline MITPA1F03 & Proteobacteria & $39 \%$ & Alphaproteobacteria & $20 \%$ & Rhodospirillales & $16 \%$ & Rhodospirillaceae & $10 \%$ & Inquilinus & $10 \%$ \\
\hline MITPA1F04 & Proteobacteria & $68 \%$ & Deltaproteobacteria & $47 \%$ & Syntrophobacterales & $23 \%$ & Syntrophobacteraceae & $17 \%$ & Desulforhabdus & $11 \%$ \\
\hline MITPA1F05 & Proteobacteria & $40 \%$ & Deltaproteobacteria & $22 \%$ & Bdellovibrionales & $9 \%$ & Bacteriovoracaceae & $9 \%$ & Peredibacter & $9 \%$ \\
\hline MITPA1F06 & Acidobacteria & $49 \%$ & Acidobacteria & $49 \%$ & Acidobacteriales & $49 \%$ & Acidobacteriaceae & $49 \%$ & Holophaga & $45 \%$ \\
\hline MITPA1F07 & Proteobacteria & $95 \%$ & Deltaproteobacteria & $95 \%$ & Desulfuromonales & $33 \%$ & Geobacteraceae & $24 \%$ & Trichlorobacter & $23 \%$ \\
\hline MITPA1F08 & Proteobacteria & $36 \%$ & Gammaproteobacteria & $24 \%$ & Xanthomonadales & $10 \%$ & Xanthomonadaceae & $10 \%$ & Nevskia & $9 \%$ \\
\hline MITPA1F09 & Proteobacteria & $42 \%$ & Deltaproteobacteria & $16 \%$ & Myxococcales & $11 \%$ & Cystobacterineae & $11 \%$ & Cystobacteraceae & $11 \%$ \\
\hline MITPA1F11 & Firmicutes & $37 \%$ & Clostridia & $21 \%$ & Clostridiales & $15 \%$ & Acidaminococcaceae & $6 \%$ & Papillibacter & $4 \%$ \\
\hline MITPA1F12 & Proteobacteria & $37 \%$ & Deltaproteobacteria & $14 \%$ & Desulfurellales & $7 \%$ & Desulfurellaceae & $7 \%$ & Hippea & $7 \%$ \\
\hline MITPA1G01 & Proteobacteria & $52 \%$ & Deltaproteobacteria & $22 \%$ & Bdellovibrionales & $11 \%$ & Bacteriovoracaceae & $11 \%$ & Peredibacter & $11 \%$ \\
\hline MITPA1G02 & Proteobacteria & $48 \%$ & Deltaproteobacteria & $24 \%$ & Desulfobacterales & $21 \%$ & Desulfobacteraceae & $21 \%$ & Desulforegula & $21 \%$ \\
\hline MITPA1G03 & Acidobacteria & $40 \%$ & Acidobacteria & $40 \%$ & Acidobacteriales & $40 \%$ & Acidobacteriaceae & $40 \%$ & Holophaga & $38 \%$ \\
\hline MITPA1G04 & Proteobacteria & $40 \%$ & Alphaproteobacteria & $16 \%$ & Rhodospirillales & $12 \%$ & Acetobacteraceae & $10 \%$ & Craurococcus & $9 \%$ \\
\hline MITPA1G05 & Acidobacteria & $41 \%$ & Acidobacteria & $41 \%$ & Acidobacteriales & $41 \%$ & Acidobacteriaceae & $41 \%$ & Acidobacterium & $20 \%$ \\
\hline MITPA1G06 & Proteobacteria & $44 \%$ & Alphaproteobacteria & $15 \%$ & Rhizobiales & $8 \%$ & Methylobacteriaceae & $8 \%$ & Microvirga & $8 \%$ \\
\hline MITPA1G07 & Proteobacteria & $36 \%$ & Deltaproteobacteria & $32 \%$ & Desulfurellales & $14 \%$ & Desulfurellaceae & $14 \%$ & Hippea & $14 \%$ \\
\hline MITPA1G08 & Chloroflexi & $38 \%$ & Anaerolineae & $38 \%$ & Anaerolinaeles & $38 \%$ & Anaerolinaeceea & $38 \%$ & Anaerolinea & $38 \%$ \\
\hline MITPA1G09 & Acidobacteria & $78 \%$ & Acidobacteria & $78 \%$ & Acidobacteriales & $78 \%$ & Acidobacteriaceae & $78 \%$ & Holophaga & $57 \%$ \\
\hline MITPA1G10 & Proteobacteria & $82 \%$ & Deltaproteobacteria & $81 \%$ & Syntrophobacterales & $44 \%$ & Syntrophobacteraceae & $43 \%$ & Desulfovirga & $34 \%$ \\
\hline MITPA1G11 & Acidobacteria & $100 \%$ & Acidobacteria & $100 \%$ & Acidobacteriales & $100 \%$ & Acidobacteriaceae & $100 \%$ & Acidobacterium & $99 \%$ \\
\hline MITPA1G12 & Acidobacteria & $77 \%$ & Acidobacteria & $77 \%$ & Acidobacteriales & $77 \%$ & Acidobacteriaceae & $77 \%$ & Holophaga & $44 \%$ \\
\hline
\end{tabular}


ANEXO B - Resultados das comparações das seqüências parciais da região 16S rRNA obtidas em amostras de solo Terra Preta Antropogênica e respectivos solos adjacentes da região Amazônica Central e Oriental, com as amostras depositadas no banco de dados de seqüências de 16S rRNA do RDP II pelo programa Classifier

\begin{tabular}{|c|c|c|c|c|c|c|c|c|c|c|}
\hline Clone & Filo & & Classe & & Ordem & & Família & & Gênero & \\
\hline MITPA1H01 & Proteobacteria & $59 \%$ & Deltaproteobacteria & $38 \%$ & Desulfuromonales & $12 \%$ & Desulfuromonaceae & $12 \%$ & Malonomonas & $12 \%$ \\
\hline MITPA1H02 & Proteobacteria & $46 \%$ & Deltaproteobacteria & $27 \%$ & Desulfovibrionales & $9 \%$ & Desulfohalobiaceae & $9 \%$ & Desulfonauticus & $4 \%$ \\
\hline MITPA1H03 & Acidobacteria & $51 \%$ & Acidobacteria & $51 \%$ & Acidobacteriales & $51 \%$ & Acidobacteriaceae & $51 \%$ & Holophaga & $37 \%$ \\
\hline MITPA1H04 & Proteobacteria & $75 \%$ & Deltaproteobacteria & $67 \%$ & Syntrophobacterales & $45 \%$ & Syntrophaceae & $34 \%$ & Smithella & $33 \%$ \\
\hline MITPA1H05 & Acidobacteria & $43 \%$ & Acidobacteria & $43 \%$ & Acidobacteriales & $43 \%$ & Acidobacteriaceae & $43 \%$ & Holophaga & $43 \%$ \\
\hline MITPA1H06 & Firmicutes & $30 \%$ & Clostridia & $27 \%$ & Thermoanaerobacteriales & $12 \%$ & Thermoanaerobacteriaceae & $12 \%$ & Thermacetogenium & $9 \%$ \\
\hline MITPA1H07 & Acidobacteria & $55 \%$ & Acidobacteria & $55 \%$ & Acidobacteriales & $55 \%$ & Acidobacteriaceae & $55 \%$ & Acidobacterium & $50 \%$ \\
\hline MITPA1H08 & Proteobacteria & $50 \%$ & Alphaproteobacteria & $32 \%$ & Rhodospirillales & $22 \%$ & Acetobacteraceae & $19 \%$ & Craurococcus & $13 \%$ \\
\hline MITPA1H09 & Proteobacteria & $64 \%$ & Epsilonproteobacteria & $33 \%$ & Nautiliales & $33 \%$ & Nautiliaceae & $33 \%$ & Lebetimonas & $29 \%$ \\
\hline MITPA1H10 & Proteobacteria & $52 \%$ & Deltaproteobacteria & $29 \%$ & Bdellovibrionales & $13 \%$ & Bacteriovoracaceae & $13 \%$ & Peredibacter & $13 \%$ \\
\hline MITPA1H11 & Acidobacteria & $41 \%$ & Acidobacteria & $41 \%$ & Acidobacteriales & $41 \%$ & Acidobacteriaceae & $41 \%$ & Holophaga & $34 \%$ \\
\hline MITPA2A01 & Acidobacteria & $67 \%$ & Acidobacteria & $67 \%$ & Acidobacteriales & $67 \%$ & Acidobacteriaceae & $67 \%$ & Acidobacterium & $63 \%$ \\
\hline MITPA2A02 & Proteobacteria & $100 \%$ & Betaproteobacteria & $99 \%$ & Burkholderiales & $90 \%$ & Comamonadaceae & $31 \%$ & Caldimonas & $12 \%$ \\
\hline MITPA2A03 & Acidobacteria & $35 \%$ & Acidobacteria & $35 \%$ & Acidobacteriales & $35 \%$ & Acidobacteriaceae & $35 \%$ & Acidobacterium & $25 \%$ \\
\hline MITPA2A04 & Firmicutes & $35 \%$ & Clostridia & $35 \%$ & Clostridiales & $32 \%$ & Acidaminococcaceae & $27 \%$ & Succiniclasticum & $11 \%$ \\
\hline MITPA2A05 & Acidobacteria & $39 \%$ & Acidobacteria & $39 \%$ & Acidobacteriales & $39 \%$ & Acidobacteriaceae & $39 \%$ & Holophaga & $39 \%$ \\
\hline MITPA2A06 & Firmicutes & $76 \%$ & Clostridia & $76 \%$ & Thermoanaerobacteriales & $74 \%$ & Thermodesulfobiaceae & $73 \%$ & Thermodesulfobium & $73 \%$ \\
\hline MITPA2A07 & Proteobacteria & $35 \%$ & Deltaproteobacteria & $27 \%$ & Myxococcales & $17 \%$ & Cystobacterineae & $17 \%$ & Cystobacteraceae & $14 \%$ \\
\hline MITPA2A08 & Acidobacteria & $51 \%$ & Acidobacteria & $51 \%$ & Acidobacteriales & $51 \%$ & Acidobacteriaceae & $51 \%$ & Holophaga & $44 \%$ \\
\hline MITPA2A09 & Proteobacteria & $65 \%$ & Deltaproteobacteria & $56 \%$ & Desulfovibrionales & $20 \%$ & Desulfovibrionaceae & $12 \%$ & Lawsonia & $12 \%$ \\
\hline MITPA2A11 & Proteobacteria & $49 \%$ & Alphaproteobacteria & $30 \%$ & Rhodospirillales & $18 \%$ & Rhodospirillaceae & $17 \%$ & Inquilinus & $17 \%$ \\
\hline MITPA2A12 & Proteobacteria & $63 \%$ & Deltaproteobacteria & $27 \%$ & Desulfobacterales & $9 \%$ & Desulfobulbaceae & $7 \%$ & Desulfofustis & $6 \%$ \\
\hline MITPA2B01 & Acidobacteria & $59 \%$ & Acidobacteria & $59 \%$ & Acidobacteriales & $59 \%$ & Acidobacteriaceae & $59 \%$ & Holophaga & $41 \%$ \\
\hline MITPA2B02 & Acidobacteria & $34 \%$ & Acidobacteria & $34 \%$ & Acidobacteriales & $34 \%$ & Acidobacteriaceae & $34 \%$ & Holophaga & $33 \%$ \\
\hline MITPA2B04 & Proteobacteria & $59 \%$ & Betaproteobacteria & $30 \%$ & Burkholderiales & $25 \%$ & Comamonadaceae & $18 \%$ & Ottowia & $9 \%$ \\
\hline MITPA2B05 & Firmicutes & $36 \%$ & Clostridia & $28 \%$ & Clostridiales & $21 \%$ & Clostridiaceae & $10 \%$ & Thermohalobacter & $6 \%$ \\
\hline MITPA2B06 & Acidobacteria & $66 \%$ & Acidobacteria & $66 \%$ & Acidobacteriales & $66 \%$ & Acidobacteriaceae & $66 \%$ & Holophaga & $63 \%$ \\
\hline MITPA2B07 & Proteobacteria & $45 \%$ & Betaproteobacteria & $16 \%$ & Burkholderiales & $10 \%$ & Alcaligenaceae & $7 \%$ & Sutterella & $7 \%$ \\
\hline MITPA2B08 & Proteobacteria & $58 \%$ & Alphaproteobacteria & $41 \%$ & Rhodospirillales & $31 \%$ & Acetobacteraceae & $27 \%$ & Craurococcus & $15 \%$ \\
\hline MITPA2B09 & Acidobacteria & $61 \%$ & Acidobacteria & $61 \%$ & Acidobacteriales & $61 \%$ & Acidobacteriaceae & $61 \%$ & Holophaga & $55 \%$ \\
\hline MITPA2B10 & Chloroflexi & $54 \%$ & Anaerolineae & $54 \%$ & Anaerolinaeles & $54 \%$ & Anaerolinaeceea & $54 \%$ & Anaerolinea & $54 \%$ \\
\hline MITPA2B11 & Acidobacteria & $41 \%$ & Acidobacteria & $41 \%$ & Acidobacteriales & $41 \%$ & Acidobacteriaceae & $41 \%$ & Holophaga & $38 \%$ \\
\hline MITPA2B12 & Proteobacteria & $52 \%$ & Epsilonproteobacteria & $22 \%$ & Nautiliales & $22 \%$ & Nautiliaceae & $22 \%$ & Lebetimonas & $20 \%$ \\
\hline MITPA2C01 & Proteobacteria & $46 \%$ & Deltaproteobacteria & $30 \%$ & Myxococcales & $18 \%$ & Cystobacterineae & $18 \%$ & Cystobacteraceae & $18 \%$ \\
\hline
\end{tabular}


ANEXO B - Resultados das comparações das seqüências parciais da região 16S rRNA obtidas em amostras de solo Terra Preta Antropogênica e respectivos solos adjacentes da região Amazônica Central e Oriental, com as amostras depositadas no banco de dados de seqüências de 16S rRNA do RDP II pelo programa Classifier

\begin{tabular}{|c|c|c|c|c|c|c|c|c|c|c|}
\hline Clone & Filo & & Classe & & Ordem & & Família & & Gênero & \\
\hline MITPA2C02 & Proteobacteria & $59 \%$ & Deltaproteobacteria & $53 \%$ & Syntrophobacterales & $17 \%$ & Syntrophobacteraceae & $14 \%$ & Desulfovirga & $11 \%$ \\
\hline MITPA2C03 & Acidobacteria & $56 \%$ & Acidobacteria & $56 \%$ & Acidobacteriales & $56 \%$ & Acidobacteriaceae & $56 \%$ & Acidobacterium & $50 \%$ \\
\hline MITPA2C04 & Acidobacteria & $57 \%$ & Acidobacteria & $57 \%$ & Acidobacteriales & $57 \%$ & Acidobacteriaceae & $57 \%$ & Holophaga & $55 \%$ \\
\hline MITPA2C05 & Proteobacteria & $79 \%$ & Epsilonproteobacteria & $35 \%$ & Nautiliales & $35 \%$ & Nautiliaceae & $35 \%$ & Lebetimonas & $33 \%$ \\
\hline MITPA2C06 & Proteobacteria & $65 \%$ & Betaproteobacteria & $22 \%$ & Burkholderiales & $16 \%$ & Comamonadaceae & $11 \%$ & Variovorax & $3 \%$ \\
\hline MITPA2C07 & Acidobacteria & $82 \%$ & Acidobacteria & $82 \%$ & Acidobacteriales & $82 \%$ & Acidobacteriaceae & $82 \%$ & Holophaga & $44 \%$ \\
\hline MITPA2C08 & Proteobacteria & $30 \%$ & Alphaproteobacteria & $18 \%$ & Rhodospirillales & $7 \%$ & Acetobacteraceae & $4 \%$ & Roseococcus & $2 \%$ \\
\hline MITPA2C09 & Chloroflexi & $32 \%$ & Anaerolineae & $32 \%$ & Anaerolinaeles & $32 \%$ & Anaerolinaeceea & $32 \%$ & Anaerolinea & $32 \%$ \\
\hline MITPA2C10 & Proteobacteria & $34 \%$ & Alphaproteobacteria & $17 \%$ & Rhodobacterales & $9 \%$ & Rhodobacteraceae & $9 \%$ & Roseisalinus & $3 \%$ \\
\hline MITPA2C11 & Acidobacteria & $61 \%$ & Acidobacteria & $61 \%$ & Acidobacteriales & $61 \%$ & Acidobacteriaceae & $61 \%$ & Holophaga & $38 \%$ \\
\hline MITPA2C12 & Acidobacteria & $44 \%$ & Acidobacteria & $44 \%$ & Acidobacteriales & $44 \%$ & Acidobacteriaceae & $44 \%$ & Holophaga & $38 \%$ \\
\hline MITPA2D01 & Proteobacteria & $75 \%$ & Deltaproteobacteria & $65 \%$ & Syntrophobacterales & $29 \%$ & Syntrophobacteraceae & $28 \%$ & Desulforhabdus & $21 \%$ \\
\hline MITPA2D02 & Proteobacteria & $42 \%$ & Deltaproteobacteria & $24 \%$ & Desulfovibrionales & $15 \%$ & Desulfohalobiaceae & $10 \%$ & Desulfonauticus & $5 \%$ \\
\hline MITPA2D03 & Acidobacteria & $99 \%$ & Acidobacteria & $99 \%$ & Acidobacteriales & $99 \%$ & Acidobacteriaceae & $99 \%$ & Acidobacterium & $99 \%$ \\
\hline MITPA2D04 & Acidobacteria & $46 \%$ & Acidobacteria & $46 \%$ & Acidobacteriales & $46 \%$ & Acidobacteriaceae & $46 \%$ & Holophaga & $45 \%$ \\
\hline MITPA2D05 & Firmicutes & $100 \%$ & Bacilli & $100 \%$ & Bacillales & $100 \%$ & Bacillaceae & $100 \%$ & Bacillus & $100 \%$ \\
\hline MITPA2D06 & Acidobacteria & $35 \%$ & Acidobacteria & $35 \%$ & Acidobacteriales & $35 \%$ & Acidobacteriaceae & $35 \%$ & Holophaga & $26 \%$ \\
\hline MITPA2D07 & Proteobacteria & $38 \%$ & Gammaproteobacteria & $15 \%$ & Enterobacteriales & $3 \%$ & Enterobacteriaceae & $3 \%$ & Alterococcus & $3 \%$ \\
\hline MITPA2D08 & Proteobacteria & $31 \%$ & Deltaproteobacteria & $14 \%$ & Syntrophobacterales & $7 \%$ & Syntrophaceae & $6 \%$ & Smithella & $6 \%$ \\
\hline MITPA2D09 & Proteobacteria & $43 \%$ & Alphaproteobacteria & $22 \%$ & Rhodospirillales & $13 \%$ & Acetobacteraceae & $8 \%$ & Teichococcus & $3 \%$ \\
\hline MITPA2D11 & Proteobacteria & $49 \%$ & Deltaproteobacteria & $19 \%$ & Desulfuromonales & $6 \%$ & Desulfuromonaceae & $5 \%$ & Malonomonas & $5 \%$ \\
\hline MITPA2D12 & Nitrospira & $100 \%$ & Nitrospira & $100 \%$ & Nitrospirales & $100 \%$ & Nitrospiraceae & $100 \%$ & Nitrospira & $100 \%$ \\
\hline MITPA2E01 & Firmicutes & $45 \%$ & Clostridia & $41 \%$ & Clostridiales & $35 \%$ & Clostridiaceae & $18 \%$ & Faecalibacterium & $17 \%$ \\
\hline MITPA2E02 & Proteobacteria & $44 \%$ & Epsilonproteobacteria & $21 \%$ & Nautiliales & $21 \%$ & Nautiliaceae & $21 \%$ & Lebetimonas & $18 \%$ \\
\hline MITPA2E03 & Firmicutes & $42 \%$ & Clostridia & $42 \%$ & Clostridiales & $42 \%$ & Clostridiaceae & $30 \%$ & Faecalibacterium & $27 \%$ \\
\hline MITPA2E04 & Acidobacteria & $77 \%$ & Acidobacteria & $77 \%$ & Acidobacteriales & $77 \%$ & Acidobacteriaceae & $77 \%$ & Holophaga & $64 \%$ \\
\hline MITPA2E05 & Proteobacteria & $46 \%$ & Deltaproteobacteria & $28 \%$ & Myxococcales & $25 \%$ & Cystobacterineae & $22 \%$ & Cystobacteraceae & $15 \%$ \\
\hline MITPA2E06 & Nitrospira & $100 \%$ & Nitrospira & $100 \%$ & Nitrospirales & $100 \%$ & Nitrospiraceae & $100 \%$ & Nitrospira & $100 \%$ \\
\hline MITPA2E07 & Acidobacteria & $38 \%$ & Acidobacteria & $38 \%$ & Acidobacteriales & $38 \%$ & Acidobacteriaceae & $38 \%$ & Holophaga & $26 \%$ \\
\hline MITPA2E08 & Proteobacteria & $34 \%$ & Deltaproteobacteria & $28 \%$ & Myxococcales & $15 \%$ & Cystobacterineae & $10 \%$ & Cystobacteraceae & $10 \%$ \\
\hline MITPA2E09 & Acidobacteria & $67 \%$ & Acidobacteria & $67 \%$ & Acidobacteriales & $67 \%$ & Acidobacteriaceae & $67 \%$ & Holophaga & $45 \%$ \\
\hline MITPA2E10 & Proteobacteria & $81 \%$ & Deltaproteobacteria & $79 \%$ & Desulfobacterales & $35 \%$ & Desulfobacteraceae & $35 \%$ & Desulfocella & $30 \%$ \\
\hline MITPA2E11 & Acidobacteria & $62 \%$ & Acidobacteria & $62 \%$ & Acidobacteriales & $62 \%$ & Acidobacteriaceae & $62 \%$ & Holophaga & $52 \%$ \\
\hline MITPA2E12 & Firmicutes & $36 \%$ & Clostridia & $32 \%$ & Clostridiales & $32 \%$ & Clostridiaceae & $21 \%$ & Faecalibacterium & $20 \%$ \\
\hline
\end{tabular}


ANEXO B - Resultados das comparações das seqüências parciais da região 16S rRNA obtidas em amostras de solo Terra Preta Antropogênica e respectivos solos adjacentes da região Amazônica Central e Oriental, com as amostras depositadas no banco de dados de seqüências de 16S rRNA do RDP II pelo programa Classifier

\begin{tabular}{|c|c|c|c|c|c|c|c|c|c|c|}
\hline Clone & Filo & & Classe & & Ordem & & Família & & Gênero & \\
\hline MITPA2F01 & Firmicutes & $36 \%$ & Clostridia & $35 \%$ & Clostridiales & $26 \%$ & Acidaminococcaceae & $11 \%$ & Centipeda & $4 \%$ \\
\hline MITPA2F02 & Chloroflexi & $53 \%$ & Anaerolineae & $53 \%$ & Anaerolinaeles & $53 \%$ & Anaerolinaeceea & $53 \%$ & Anaerolinea & $53 \%$ \\
\hline MITPA2F03 & Acidobacteria & $63 \%$ & Acidobacteria & $63 \%$ & Acidobacteriales & $63 \%$ & Acidobacteriaceae & $63 \%$ & Holophaga & $54 \%$ \\
\hline MITPA2F04 & Acidobacteria & $43 \%$ & Acidobacteria & $43 \%$ & Acidobacteriales & $43 \%$ & Acidobacteriaceae & $43 \%$ & Holophaga & $29 \%$ \\
\hline MITPA2F05 & Proteobacteria & $62 \%$ & Alphaproteobacteria & $27 \%$ & Rhodospirillales & $26 \%$ & Acetobacteraceae & $22 \%$ & Craurococcus & $20 \%$ \\
\hline MITPA2F06 & Proteobacteria & $31 \%$ & Gammaproteobacteria & $11 \%$ & Xanthomonadales & $6 \%$ & Xanthomonadaceae & $6 \%$ & Luteimonas & $2 \%$ \\
\hline MITPA2F07 & Proteobacteria & $42 \%$ & Alphaproteobacteria & $24 \%$ & Rhodospirillales & $23 \%$ & Rhodospirillaceae & $18 \%$ & Inquilinus & $17 \%$ \\
\hline MITPA2F08 & Acidobacteria & $82 \%$ & Acidobacteria & $82 \%$ & Acidobacteriales & $82 \%$ & Acidobacteriaceae & $82 \%$ & Acidobacterium & $76 \%$ \\
\hline MITPA2F09 & Proteobacteria & $42 \%$ & Alphaproteobacteria & $21 \%$ & Rhodospirillales & $18 \%$ & Acetobacteraceae & $16 \%$ & Craurococcus & $14 \%$ \\
\hline MITPA2F11 & Acidobacteria & $49 \%$ & Acidobacteria & $49 \%$ & Acidobacteriales & $49 \%$ & Acidobacteriaceae & $49 \%$ & Holophaga & $42 \%$ \\
\hline MITPA2F 12 & Firmicutes & $34 \%$ & Clostridia & $33 \%$ & Clostridiales & $23 \%$ & Acidaminococcaceae & $9 \%$ & Allisonella & $3 \%$ \\
\hline MITPA2G01 & Proteobacteria & $50 \%$ & Deltaproteobacteria & $38 \%$ & Myxococcales & $29 \%$ & Cystobacterineae & $24 \%$ & Cystobacteraceae & $22 \%$ \\
\hline MITPA2G02 & Firmicutes & $41 \%$ & Clostridia & $39 \%$ & Clostridiales & $30 \%$ & Clostridiaceae & $10 \%$ & Faecalibacterium & $3 \%$ \\
\hline MITPA2G03 & Proteobacteria & $52 \%$ & Deltaproteobacteria & $42 \%$ & Myxococcales & $41 \%$ & Cystobacterineae & $41 \%$ & Cystobacteraceae & $26 \%$ \\
\hline MITPA2G04 & Acidobacteria & $39 \%$ & Acidobacteria & $39 \%$ & Acidobacteriales & $39 \%$ & Acidobacteriaceae & $39 \%$ & Holophaga & $24 \%$ \\
\hline MITPA2G05 & Firmicutes & $37 \%$ & Clostridia & $35 \%$ & Clostridiales & $27 \%$ & Acidaminococcaceae & $18 \%$ & Allisonella & $11 \%$ \\
\hline MITPA2G06 & Firmicutes & $33 \%$ & Clostridia & $32 \%$ & Clostridiales & $29 \%$ & Acidaminococcaceae & $25 \%$ & Succinispira & $11 \%$ \\
\hline MITPA2G07 & Acidobacteria & $77 \%$ & Acidobacteria & $77 \%$ & Acidobacteriales & $77 \%$ & Acidobacteriaceae & $77 \%$ & Holophaga & $62 \%$ \\
\hline MITPA2G08 & Acidobacteria & $41 \%$ & Acidobacteria & $41 \%$ & Acidobacteriales & $41 \%$ & Acidobacteriaceae & $41 \%$ & Acidobacterium & $26 \%$ \\
\hline MITPA2G09 & Proteobacteria & $91 \%$ & Deltaproteobacteria & $87 \%$ & Syntrophobacterales & $23 \%$ & Syntrophaceae & $21 \%$ & Desulfobacca & $21 \%$ \\
\hline MITPA2G11 & Proteobacteria & $90 \%$ & Deltaproteobacteria & $87 \%$ & Myxococcales & $84 \%$ & Sorangineae & $72 \%$ & Polyangiaceae & $72 \%$ \\
\hline MITPA2G12 & Proteobacteria & $34 \%$ & Alphaproteobacteria & $18 \%$ & Rhodospirillales & $17 \%$ & Rhodospirillaceae & $9 \%$ & Inquilinus & $9 \%$ \\
\hline MITPA2H01 & Proteobacteria & $37 \%$ & Deltaproteobacteria & $20 \%$ & Desulfurellales & $8 \%$ & Desulfurellaceae & $8 \%$ & Hippea & $8 \%$ \\
\hline MITPA2H02 & Acidobacteria & $40 \%$ & Acidobacteria & $40 \%$ & Acidobacteriales & $40 \%$ & Acidobacteriaceae & $40 \%$ & Acidobacterium & $21 \%$ \\
\hline MITPA2H03 & Acidobacteria & $47 \%$ & Acidobacteria & $47 \%$ & Acidobacteriales & $47 \%$ & Acidobacteriaceae & $47 \%$ & Holophaga & $39 \%$ \\
\hline MITPA2H04 & Firmicutes & $46 \%$ & Clostridia & $46 \%$ & Clostridiales & $33 \%$ & Clostridiaceae & $21 \%$ & Faecalibacterium & $19 \%$ \\
\hline MITPA2H05 & Acidobacteria & $69 \%$ & Acidobacteria & $69 \%$ & Acidobacteriales & $69 \%$ & Acidobacteriaceae & $69 \%$ & Holophaga & $40 \%$ \\
\hline MITPA2H06 & Proteobacteria & $100 \%$ & Betaproteobacteria & $95 \%$ & Burkholderiales & $88 \%$ & Incertae sedis 5 & $49 \%$ & Thiobacter & $34 \%$ \\
\hline MITPA2H08 & Acidobacteria & $93 \%$ & Acidobacteria & $93 \%$ & Acidobacteriales & $93 \%$ & Acidobacteriaceae & $93 \%$ & Acidobacterium & $90 \%$ \\
\hline MITPA2H09 & Proteobacteria & $69 \%$ & Betaproteobacteria & $41 \%$ & Burkholderiales & $25 \%$ & Comamonadaceae & $16 \%$ & Alicycliphilus & $7 \%$ \\
\hline MITPA2H10 & Chloroflexi & $62 \%$ & Anaerolineae & $62 \%$ & Anaerolinaeles & $62 \%$ & Anaerolinaeceea & $62 \%$ & Anaerolinea & $62 \%$ \\
\hline MITPA2H11 & Proteobacteria & $43 \%$ & Alphaproteobacteria & $29 \%$ & Rhodospirillales & $29 \%$ & Rhodospirillaceae & $18 \%$ & Tistrella & $14 \%$ \\
\hline MITPA3A01 & Acidobacteria & $40 \%$ & Acidobacteria & $40 \%$ & Acidobacteriales & $40 \%$ & Acidobacteriaceae & $40 \%$ & Holophaga & $24 \%$ \\
\hline MITPA3А02 & Proteobacteria & $43 \%$ & Gammaproteobacteria & $18 \%$ & Chromatiales & $16 \%$ & Chromatiaceae & $14 \%$ & Thioflavicoccus & $5 \%$ \\
\hline
\end{tabular}


ANEXO B - Resultados das comparações das seqüências parciais da região 16S rRNA obtidas em amostras de solo Terra Preta Antropogênica e respectivos solos adjacentes da região Amazônica Central e Oriental, com as amostras depositadas no banco de dados de seqüências de 16S rRNA do RDP II pelo programa Classifier

\begin{tabular}{|c|c|c|c|c|c|c|c|c|c|c|}
\hline Clone & Filo & & Classe & & Ordem & & Família & & Gênero & \\
\hline MITPA3A03 & Proteobacteria & $47 \%$ & Alphaproteobacteria & $22 \%$ & Rhodospirillales & $17 \%$ & Acetobacteraceae & $12 \%$ & Craurococcus & $10 \%$ \\
\hline MITPA3A04 & Firmicutes & $37 \%$ & Clostridia & $37 \%$ & Clostridiales & $35 \%$ & Clostridiaceae & $23 \%$ & Faecalibacterium & $21 \%$ \\
\hline MITPA3A05 & Acidobacteria & $40 \%$ & Acidobacteria & $40 \%$ & Acidobacteriales & $40 \%$ & Acidobacteriaceae & $40 \%$ & Geothrix & $20 \%$ \\
\hline MITPA3A06 & Acidobacteria & $52 \%$ & Acidobacteria & $52 \%$ & Acidobacteriales & $52 \%$ & Acidobacteriaceae & $52 \%$ & Holophaga & $27 \%$ \\
\hline MITPA3А07 & Proteobacteria & $41 \%$ & Gammaproteobacteria & $17 \%$ & Chromatiales & $8 \%$ & Ectothiorhodospiraceae & $4 \%$ & Thiorhodospira & $4 \%$ \\
\hline MITPA3А09 & Proteobacteria & $53 \%$ & Alphaproteobacteria & $26 \%$ & Rhodospirillales & $23 \%$ & Acetobacteraceae & $12 \%$ & Kozakia & $8 \%$ \\
\hline MITPA3A10 & Firmicutes & $100 \%$ & Bacilli & $100 \%$ & Bacillales & $100 \%$ & Bacillaceae & $100 \%$ & Bacillus & $100 \%$ \\
\hline MITPA3A11 & Proteobacteria & $35 \%$ & Gammaproteobacteria & $20 \%$ & Chromatiales & $14 \%$ & Chromatiaceae & $11 \%$ & Thiorhodococcus & $6 \%$ \\
\hline MITPA3A12 & Proteobacteria & $57 \%$ & Gammaproteobacteria & $29 \%$ & Enterobacteriales & $11 \%$ & Enterobacteriaceae & $11 \%$ & Alterococcus & $11 \%$ \\
\hline МITPA3B01 & Acidobacteria & $69 \%$ & Acidobacteria & $69 \%$ & Acidobacteriales & $69 \%$ & Acidobacteriaceae & $69 \%$ & Holophaga & $46 \%$ \\
\hline MITPA3B02 & Proteobacteria & $50 \%$ & Alphaproteobacteria & $29 \%$ & Rhodospirillales & $21 \%$ & Rhodospirillaceae & $15 \%$ & Inquilinus & $13 \%$ \\
\hline МITPA3В03 & Proteobacteria & $54 \%$ & Gammaproteobacteria & $22 \%$ & Chromatiales & $14 \%$ & Chromatiaceae & $14 \%$ & Thiorhodococcus & $10 \%$ \\
\hline MITPA3В04 & Chloroflexi & $31 \%$ & Anaerolineae & $31 \%$ & Anaerolinaeles & $31 \%$ & Anaerolinaeceea & $31 \%$ & Anaerolinea & $31 \%$ \\
\hline MITPA3B05 & Proteobacteria & $98 \%$ & Deltaproteobacteria & $98 \%$ & Syntrophobacterales & $48 \%$ & Syntrophaceae & $31 \%$ & Smithella & $31 \%$ \\
\hline MITPA3В06 & Proteobacteria & $77 \%$ & Deltaproteobacteria & $56 \%$ & Desulfobacterales & $20 \%$ & Desulfobacteraceae & $17 \%$ & Desulforegula & $12 \%$ \\
\hline MITPA3В07 & Firmicutes & $32 \%$ & Clostridia & $31 \%$ & Clostridiales & $30 \%$ & Clostridiaceae & $21 \%$ & Faecalibacterium & $18 \%$ \\
\hline МITPA3В08 & Planctomycetes & $99 \%$ & Planctomycetacia & $99 \%$ & Planctomycetales & $99 \%$ & Planctomycetaceae & $99 \%$ & Pirellula & $76 \%$ \\
\hline МITPA3В09 & Proteobacteria & $55 \%$ & Betaproteobacteria & $18 \%$ & Burkholderiales & $14 \%$ & Comamonadaceae & $11 \%$ & Ottowia & $3 \%$ \\
\hline MITPA3B10 & Firmicutes & $37 \%$ & Clostridia & $36 \%$ & Clostridiales & $35 \%$ & Clostridiaceae & $20 \%$ & Faecalibacterium & $19 \%$ \\
\hline MITPA3B11 & Acidobacteria & $40 \%$ & Acidobacteria & $40 \%$ & Acidobacteriales & $40 \%$ & Acidobacteriaceae & $40 \%$ & Holophaga & $36 \%$ \\
\hline MITPA3C01 & Proteobacteria & $57 \%$ & Deltaproteobacteria & $38 \%$ & Desulfobacterales & $21 \%$ & Desulfobacteraceae & $19 \%$ & Desulforegula & $14 \%$ \\
\hline MITPA3C02 & Proteobacteria & $37 \%$ & Deltaproteobacteria & $22 \%$ & Myxococcales & $8 \%$ & Nannocystineae & $8 \%$ & Nannocystaceae & $8 \%$ \\
\hline MITPA3С03 & Firmicutes & $31 \%$ & Clostridia & $27 \%$ & Clostridiales & $22 \%$ & Acidaminococcaceae & $11 \%$ & Centipeda & $5 \%$ \\
\hline MITPA3C04 & Acidobacteria & $37 \%$ & Acidobacteria & $37 \%$ & Acidobacteriales & $37 \%$ & Acidobacteriaceae & $37 \%$ & Holophaga & $35 \%$ \\
\hline MITPA3C05 & Proteobacteria & $59 \%$ & Betaproteobacteria & $20 \%$ & Neisseriales & $12 \%$ & Neisseriaceae & $12 \%$ & Laribacter & $10 \%$ \\
\hline MITPA3C06 & Acidobacteria & $38 \%$ & Acidobacteria & $38 \%$ & Acidobacteriales & $38 \%$ & Acidobacteriaceae & $38 \%$ & Holophaga & $25 \%$ \\
\hline МITPA3С07 & Verrucomicrobia & $98 \%$ & Verrucomicrobiae & $98 \%$ & Verrucomicrobiales & $98 \%$ & Xiphinematobacteriaceae & $82 \%$ & Xiphinematobacter & $82 \%$ \\
\hline MITPA3C08 & Proteobacteria & $64 \%$ & Deltaproteobacteria & $59 \%$ & Syntrophobacterales & $46 \%$ & Syntrophobacteraceae & $43 \%$ & Desulfovirga & $39 \%$ \\
\hline MITPA3С09 & Acidobacteria & $61 \%$ & Acidobacteria & $61 \%$ & Acidobacteriales & $61 \%$ & Acidobacteriaceae & $61 \%$ & Holophaga & $52 \%$ \\
\hline MITPA3C 10 & Proteobacteria & $38 \%$ & Deltaproteobacteria & $19 \%$ & Syntrophobacterales & $7 \%$ & Syntrophaceae & $4 \%$ & Smithella & $3 \%$ \\
\hline MITPA3C11 & Proteobacteria & $40 \%$ & Deltaproteobacteria & $27 \%$ & Desulfobacterales & $10 \%$ & Desulfobacteraceae & $6 \%$ & Desulforegula & $6 \%$ \\
\hline MITPA3C12 & Acidobacteria & $33 \%$ & Acidobacteria & $33 \%$ & Acidobacteriales & $33 \%$ & Acidobacteriaceae & $33 \%$ & Holophaga & $32 \%$ \\
\hline MITPA3D01 & Proteobacteria & $92 \%$ & Deltaproteobacteria & $92 \%$ & Syntrophobacterales & $80 \%$ & Syntrophobacteraceae & $70 \%$ & Desulfovirga & $55 \%$ \\
\hline MITPA3D03 & Firmicutes & $41 \%$ & Clostridia & $39 \%$ & Clostridiales & $29 \%$ & Clostridiaceae & $11 \%$ & Faecalibacterium & $5 \%$ \\
\hline
\end{tabular}


ANEXO B - Resultados das comparações das seqüências parciais da região 16S rRNA obtidas em amostras de solo Terra Preta Antropogênica e respectivos solos adjacentes da região Amazônica Central e Oriental, com as amostras depositadas no banco de dados de seqüências de 16S rRNA do RDP II pelo programa Classifier

\begin{tabular}{|c|c|c|c|c|c|c|c|c|c|c|}
\hline Clone & Filo & & Classe & & Ordem & & Família & & Gênero & \\
\hline MITPA3D04 & Firmicutes & $39 \%$ & Clostridia & $38 \%$ & Clostridiales & $29 \%$ & Acidaminococcaceae & $14 \%$ & Acetonema & $5 \%$ \\
\hline MITPA3D05 & Firmicutes & $55 \%$ & Clostridia & $54 \%$ & Clostridiales & $52 \%$ & Clostridiaceae & $29 \%$ & Faecalibacterium & $27 \%$ \\
\hline MITPA3D06 & Acidobacteria & $55 \%$ & Acidobacteria & $55 \%$ & Acidobacteriales & $55 \%$ & Acidobacteriaceae & $55 \%$ & Holophaga & $38 \%$ \\
\hline MITPA3D07 & Proteobacteria & $40 \%$ & Alphaproteobacteria & $13 \%$ & Rhizobiales & $6 \%$ & Rhodobiaceae & $3 \%$ & Parvibaculum & $3 \%$ \\
\hline MITPA3D08 & Proteobacteria & $63 \%$ & Deltaproteobacteria & $61 \%$ & Syntrophobacterales & $28 \%$ & Syntrophobacteraceae & $25 \%$ & Desulfovirga & $23 \%$ \\
\hline MITPA3D09 & Proteobacteria & $55 \%$ & Betaproteobacteria & $29 \%$ & Burkholderiales & $20 \%$ & Comamonadaceae & $11 \%$ & Ottowia & $4 \%$ \\
\hline MITPA3D10 & Proteobacteria & $49 \%$ & Betaproteobacteria & $22 \%$ & Burkholderiales & $15 \%$ & Comamonadaceae & $12 \%$ & Hylemonella & $6 \%$ \\
\hline MITPA3D11 & Proteobacteria & $46 \%$ & Gammaproteobacteria & $25 \%$ & Chromatiales & $9 \%$ & Ectothiorhodospiraceae & $6 \%$ & Thiorhodospira & $5 \%$ \\
\hline MITPA3D12 & Proteobacteria & $52 \%$ & Betaproteobacteria & $19 \%$ & Burkholderiales & $9 \%$ & Alcaligenaceae & $5 \%$ & Sutterella & $4 \%$ \\
\hline MITPA3E01 & Proteobacteria & $70 \%$ & Deltaproteobacteria & $60 \%$ & Myxococcales & $30 \%$ & Cystobacterineae & $30 \%$ & Cystobacteraceae & $30 \%$ \\
\hline MITPA3E02 & Proteobacteria & $50 \%$ & Deltaproteobacteria & $20 \%$ & Myxococcales & $10 \%$ & Cystobacterineae & $10 \%$ & Cystobacteraceae & $10 \%$ \\
\hline MITPA3E03 & Acidobacteria & $62 \%$ & Acidobacteria & $62 \%$ & Acidobacteriales & $62 \%$ & Acidobacteriaceae & $62 \%$ & Acidobacterium & $58 \%$ \\
\hline MITPA3E04 & Acidobacteria & $46 \%$ & Acidobacteria & $46 \%$ & Acidobacteriales & $46 \%$ & Acidobacteriaceae & $46 \%$ & Holophaga & $37 \%$ \\
\hline MITPA3E05 & Proteobacteria & $58 \%$ & Epsilonproteobacteria & $20 \%$ & Nautiliales & $20 \%$ & Nautiliaceae & $20 \%$ & Lebetimonas & $20 \%$ \\
\hline MITPA3E06 & Proteobacteria & $49 \%$ & Epsilonproteobacteria & $19 \%$ & Nautiliales & $19 \%$ & Nautiliaceae & $19 \%$ & Lebetimonas & $19 \%$ \\
\hline MITPA3E07 & Proteobacteria & $54 \%$ & Deltaproteobacteria & $21 \%$ & Desulfuromonales & $9 \%$ & Geobacteraceae & $9 \%$ & Trichlorobacter & $9 \%$ \\
\hline MITPA3E08 & Nitrospira & $100 \%$ & Nitrospira & $100 \%$ & Nitrospirales & $100 \%$ & Nitrospiraceae & $100 \%$ & Nitrospira & $100 \%$ \\
\hline MITPA3E09 & Firmicutes & $54 \%$ & Clostridia & $53 \%$ & Thermoanaerobacteriales & $30 \%$ & Thermoanaerobacteriaceae & $28 \%$ & Gelria & $28 \%$ \\
\hline MITPA3E10 & Proteobacteria & $43 \%$ & Alphaproteobacteria & $20 \%$ & Rhodospirillales & $13 \%$ & Rhodospirillaceae & $10 \%$ & Inquilinus & $10 \%$ \\
\hline MITPA3E11 & Proteobacteria & $53 \%$ & Deltaproteobacteria & $19 \%$ & Desulfuromonales & $8 \%$ & Geobacteraceae & $8 \%$ & Trichlorobacter & $8 \%$ \\
\hline MITPA3F01 & Firmicutes & $54 \%$ & Clostridia & $54 \%$ & Clostridiales & $49 \%$ & Clostridiaceae & $27 \%$ & Faecalibacterium & $24 \%$ \\
\hline MITPA3F02 & Firmicutes & $34 \%$ & Clostridia & $33 \%$ & Clostridiales & $33 \%$ & Clostridiaceae & $21 \%$ & Faecalibacterium & $21 \%$ \\
\hline MITPA3F03 & Firmicutes & $48 \%$ & Clostridia & $47 \%$ & Clostridiales & $45 \%$ & Clostridiaceae & $30 \%$ & Faecalibacterium & $28 \%$ \\
\hline MITPA3F04 & Proteobacteria & $80 \%$ & Deltaproteobacteria & $38 \%$ & Syntrophobacterales & $18 \%$ & Syntrophobacteraceae & $18 \%$ & Desulfovirga & $14 \%$ \\
\hline MITPA3F05 & Firmicutes & $38 \%$ & Clostridia & $38 \%$ & Clostridiales & $32 \%$ & Acidaminococcaceae & $15 \%$ & Allisonella & $8 \%$ \\
\hline MITPA3F06 & Proteobacteria & $41 \%$ & Deltaproteobacteria & $22 \%$ & Desulfobacterales & $6 \%$ & Desulfobulbaceae & $5 \%$ & Desulfofustis & $5 \%$ \\
\hline MITPA3F07 & Proteobacteria & $100 \%$ & Alphaproteobacteria & $100 \%$ & Rhizobiales & $96 \%$ & Methylobacteriaceae & $49 \%$ & Microvirga & $49 \%$ \\
\hline MITPA3F08 & Proteobacteria & $50 \%$ & Alphaproteobacteria & $18 \%$ & Rhodospirillales & $9 \%$ & Rhodospirillaceae & $7 \%$ & Inquilinus & $4 \%$ \\
\hline MITPA3F09 & Proteobacteria & $38 \%$ & Gammaproteobacteria & $15 \%$ & Chromatiales & $11 \%$ & Chromatiaceae & $9 \%$ & Thiorhodococcus & $8 \%$ \\
\hline MITPA3F10 & Acidobacteria & $45 \%$ & Acidobacteria & $45 \%$ & Acidobacteriales & $45 \%$ & Acidobacteriaceae & $45 \%$ & Holophaga & $36 \%$ \\
\hline MITPA3F11 & Proteobacteria & $71 \%$ & Deltaproteobacteria & $53 \%$ & Desulfobacterales & $24 \%$ & Desulfobacteraceae & $22 \%$ & Desulforegula & $17 \%$ \\
\hline MITPA3F12 & Acidobacteria & $43 \%$ & Acidobacteria & $43 \%$ & Acidobacteriales & $43 \%$ & Acidobacteriaceae & $43 \%$ & Acidobacterium & $31 \%$ \\
\hline MITPA3G01 & Proteobacteria & $35 \%$ & Alphaproteobacteria & $14 \%$ & Rhodospirillales & $9 \%$ & Rhodospirillaceae & $5 \%$ & Inquilinus & $5 \%$ \\
\hline MITPA3G02 & Planctomycetes & $98 \%$ & Planctomycetacia & $98 \%$ & Planctomycetales & $98 \%$ & Planctomycetaceae & $98 \%$ & Pirellula & $81 \%$ \\
\hline
\end{tabular}


ANEXO B - Resultados das comparações das seqüências parciais da região 16S rRNA obtidas em amostras de solo Terra Preta Antropogênica e respectivos solos adjacentes da região Amazônica Central e Oriental, com as amostras depositadas no banco de dados de seqüências de 16S rRNA do RDP II pelo programa Classifier

\begin{tabular}{|c|c|c|c|c|c|c|c|c|c|c|}
\hline Clone & Filo & & Classe & & Ordem & & Família & & Gênero & \\
\hline MITPA3G03 & Firmicutes & $37 \%$ & Clostridia & $37 \%$ & Clostridiales & $30 \%$ & Acidaminococcaceae & $19 \%$ & Allisonella & $10 \%$ \\
\hline MITPA3G04 & Proteobacteria & $34 \%$ & Alphaproteobacteria & $20 \%$ & Rhodospirillales & $12 \%$ & Acetobacteraceae & $12 \%$ & Swaminathania & $4 \%$ \\
\hline MITPA3G05 & Proteobacteria & $75 \%$ & Gammaproteobacteria & $36 \%$ & Chromatiales & $22 \%$ & Chromatiaceae & $15 \%$ & Thiorhodococcus & $4 \%$ \\
\hline MITPA3G06 & Proteobacteria & $71 \%$ & Deltaproteobacteria & $52 \%$ & Syntrophobacterales & $20 \%$ & Syntrophobacteraceae & $17 \%$ & Desulforhabdus & $9 \%$ \\
\hline MITPA3G07 & Proteobacteria & $41 \%$ & Deltaproteobacteria & $16 \%$ & Syntrophobacterales & $10 \%$ & Syntrophobacteraceae & $10 \%$ & Desulfovirga & $6 \%$ \\
\hline MITPA3G09 & Firmicutes & $34 \%$ & Clostridia & $33 \%$ & Clostridiales & $32 \%$ & Clostridiaceae & $20 \%$ & Faecalibacterium & $19 \%$ \\
\hline MITPA3G10 & Acidobacteria & $49 \%$ & Acidobacteria & $49 \%$ & Acidobacteriales & $49 \%$ & Acidobacteriaceae & $49 \%$ & Acidobacterium & $46 \%$ \\
\hline MITPA3G11 & Proteobacteria & $44 \%$ & Alphaproteobacteria & $18 \%$ & Rhodospirillales & $14 \%$ & Acetobacteraceae & $7 \%$ & Craurococcus & $5 \%$ \\
\hline MITPA3G12 & Acidobacteria & $36 \%$ & Acidobacteria & $36 \%$ & Acidobacteriales & $36 \%$ & Acidobacteriaceae & $36 \%$ & Holophaga & $30 \%$ \\
\hline MITPA3H01 & Firmicutes & $41 \%$ & Clostridia & $40 \%$ & Clostridiales & $34 \%$ & Acidaminococcaceae & $33 \%$ & Succiniclasticum & $21 \%$ \\
\hline MITPA3H02 & Planctomycetes & $97 \%$ & Planctomycetacia & $97 \%$ & Planctomycetales & $97 \%$ & Planctomycetaceae & $97 \%$ & Isosphaera & $86 \%$ \\
\hline МITPA3H03 & Proteobacteria & $61 \%$ & Deltaproteobacteria & $25 \%$ & Desulfuromonales & $7 \%$ & Desulfuromonaceae & $7 \%$ & Malonomonas & $7 \%$ \\
\hline MITPA3H04 & Proteobacteria & $61 \%$ & Deltaproteobacteria & $54 \%$ & Desulfovibrionales & $14 \%$ & Desulfohalobiaceae & $8 \%$ & Desulfonauticus & $8 \%$ \\
\hline MITPA3H05 & Proteobacteria & $42 \%$ & Alphaproteobacteria & $18 \%$ & Rhodospirillales & $7 \%$ & Rhodospirillaceae & $6 \%$ & Rhodocista & $6 \%$ \\
\hline MITPA3H06 & Acidobacteria & $39 \%$ & Acidobacteria & $39 \%$ & Acidobacteriales & $39 \%$ & Acidobacteriaceae & $39 \%$ & Acidobacterium & $19 \%$ \\
\hline MITPA3H07 & Proteobacteria & $45 \%$ & Deltaproteobacteria & $42 \%$ & Syntrophobacterales & $30 \%$ & Syntrophobacteraceae & $27 \%$ & Desulfovirga & $21 \%$ \\
\hline MITPA3H08 & Firmicutes & $39 \%$ & Clostridia & $39 \%$ & Clostridiales & $29 \%$ & Acidaminococcaceae & $14 \%$ & Acetonema & $4 \%$ \\
\hline MITPA3H09 & Proteobacteria & $80 \%$ & Deltaproteobacteria & $75 \%$ & Myxococcales & $67 \%$ & Sorangineae & $37 \%$ & Polyangiaceae & $37 \%$ \\
\hline MITPA3H10 & Firmicutes & $74 \%$ & Clostridia & $74 \%$ & Thermoanaerobacteriales & $73 \%$ & Thermodesulfobiaceae & $73 \%$ & Thermodesulfobium & $73 \%$ \\
\hline MITPA3H11 & Proteobacteria & $35 \%$ & Alphaproteobacteria & $19 \%$ & Rhodospirillales & $16 \%$ & Acetobacteraceae & $14 \%$ & Craurococcus & $5 \%$ \\
\hline MIADJ1A01 & Proteobacteria & $100 \%$ & Betaproteobacteria & $100 \%$ & Burkholderiales & $96 \%$ & Incertae sedis 5 & $43 \%$ & Rubrivivax & $31 \%$ \\
\hline MIADJ1A02 & Proteobacteria & $58 \%$ & Deltaproteobacteria & $38 \%$ & Bdellovibrionales & $13 \%$ & Bacteriovoracaceae & $13 \%$ & Peredibacter & $13 \%$ \\
\hline MIADJ1A03 & Verrucomicrobia & $64 \%$ & Verrucomicrobiae & $64 \%$ & Verrucomicrobiales & $64 \%$ & Opitutaceae & $32 \%$ & Opitutus & $32 \%$ \\
\hline MIADJ1A04 & Proteobacteria & $100 \%$ & Gammaproteobacteria & $93 \%$ & Legionellales & $75 \%$ & Coxiellaceae & $75 \%$ & Rickettsiella & $75 \%$ \\
\hline MIADJ1A05 & Nitrospira & $100 \%$ & Nitrospira & $100 \%$ & Nitrospirales & $100 \%$ & Nitrospiraceae & $100 \%$ & Nitrospira & $100 \%$ \\
\hline MIADJ1A06 & Proteobacteria & $38 \%$ & Alphaproteobacteria & $18 \%$ & Rhodospirillales & $13 \%$ & Acetobacteraceae & $7 \%$ & Craurococcus & $3 \%$ \\
\hline MIADJ1A07 & Verrucomicrobia & $74 \%$ & Verrucomicrobiae & $74 \%$ & Verrucomicrobiales & $74 \%$ & Verrucomicrobiaceae & $56 \%$ & Verrucomicrobium & $56 \%$ \\
\hline MIADJ1A08 & Verrucomicrobia & $97 \%$ & Verrucomicrobiae & $97 \%$ & Verrucomicrobiales & $97 \%$ & Xiphinematobacteriaceae & $55 \%$ & Xiphinematobacter & $55 \%$ \\
\hline MIADJ1A11 & Acidobacteria & $98 \%$ & Acidobacteria & $98 \%$ & Acidobacteriales & $98 \%$ & Acidobacteriaceae & $98 \%$ & Acidobacterium & $92 \%$ \\
\hline MIADJ1A12 & Proteobacteria & $41 \%$ & Deltaproteobacteria & $32 \%$ & Syntrophobacterales & $25 \%$ & Syntrophobacteraceae & $25 \%$ & Thermodesulforhabdus & $14 \%$ \\
\hline MIADJ1B01 & Acidobacteria & $100 \%$ & Acidobacteria & $100 \%$ & Acidobacteriales & $100 \%$ & Acidobacteriaceae & $100 \%$ & Acidobacterium & $100 \%$ \\
\hline MIADJ1B02 & Proteobacteria & $58 \%$ & Deltaproteobacteria & $43 \%$ & Myxococcales & $32 \%$ & Cystobacterineae & $31 \%$ & Cystobacteraceae & $31 \%$ \\
\hline MIADJ1B03 & Acidobacteria & $94 \%$ & Acidobacteria & $94 \%$ & Acidobacteriales & $94 \%$ & Acidobacteriaceae & $94 \%$ & Acidobacterium & $92 \%$ \\
\hline MIADJ1B04 & Nitrospira & $98 \%$ & Nitrospira & $98 \%$ & Nitrospirales & $98 \%$ & Nitrospiraceae & $98 \%$ & Nitrospira & $98 \%$ \\
\hline
\end{tabular}


ANEXO B - Resultados das comparações das seqüências parciais da região 16S rRNA obtidas em amostras de solo Terra Preta Antropogênica e respectivos solos adjacentes da região Amazônica Central e Oriental, com as amostras depositadas no banco de dados de seqüências de 16S rRNA do RDP II pelo programa Classifier

\begin{tabular}{|c|c|c|c|c|c|c|c|c|c|c|}
\hline Clone & Filo & & Classe & & Ordem & & Família & & Gênero & \\
\hline MIADJ1B05 & Acidobacteria & $100 \%$ & Acidobacteria & $100 \%$ & Acidobacteriales & $100 \%$ & Acidobacteriaceae & $100 \%$ & Acidobacterium & $100 \%$ \\
\hline MIADJ1B06 & Proteobacteria & $100 \%$ & Betaproteobacteria & $100 \%$ & Burkholderiales & $92 \%$ & Comamonadaceae & $50 \%$ & Xenophilus & $45 \%$ \\
\hline MIADJ1B08 & Proteobacteria & $42 \%$ & Deltaproteobacteria & $32 \%$ & Myxococcales & $30 \%$ & Cystobacterineae & $30 \%$ & Cystobacteraceae & $30 \%$ \\
\hline MIADJ1B09 & Proteobacteria & $100 \%$ & Gammaproteobacteria & $100 \%$ & Xanthomonadales & $100 \%$ & Xanthomonadaceae & $100 \%$ & Frateuria & $100 \%$ \\
\hline MIADJ1B10 & Acidobacteria & $100 \%$ & Acidobacteria & $100 \%$ & Acidobacteriales & $100 \%$ & Acidobacteriaceae & $100 \%$ & Acidobacterium & $99 \%$ \\
\hline MIADJ1B11 & Verrucomicrobia & $92 \%$ & Verrucomicrobiae & $92 \%$ & Verrucomicrobiales & $92 \%$ & Verrucomicrobiaceae & $46 \%$ & Verrucomicrobium & $45 \%$ \\
\hline MIADJ1C01 & Acidobacteria & $100 \%$ & Acidobacteria & $100 \%$ & Acidobacteriales & $100 \%$ & Acidobacteriaceae & $100 \%$ & Acidobacterium & $100 \%$ \\
\hline MIADJ1C02 & Firmicutes & $45 \%$ & Clostridia & $45 \%$ & Clostridiales & $40 \%$ & Clostridiaceae & $18 \%$ & Acetanaerobacterium & $7 \%$ \\
\hline MIADJ1C03 & Proteobacteria & $40 \%$ & Deltaproteobacteria & $23 \%$ & Myxococcales & $21 \%$ & Cystobacterineae & $19 \%$ & Cystobacteraceae & $19 \%$ \\
\hline MIADJ1C04 & Proteobacteria & $40 \%$ & Deltaproteobacteria & $31 \%$ & Myxococcales & $29 \%$ & Cystobacterineae & $25 \%$ & Cystobacteraceae & $24 \%$ \\
\hline MIADJ1C05 & Proteobacteria & $100 \%$ & Alphaproteobacteria & $100 \%$ & Rhizobiales & $100 \%$ & Bradyrhizobiaceae & $45 \%$ & Nitrobacter & $37 \%$ \\
\hline MIADJ1C06 & Aquificae & $30 \%$ & Aquificae & $30 \%$ & Aquificales & $30 \%$ & Incertae sedis 2 & $23 \%$ & Balnearium & $19 \%$ \\
\hline MIADJ1C08 & Proteobacteria & $55 \%$ & Deltaproteobacteria & $32 \%$ & Myxococcales & $27 \%$ & Cystobacterineae & $26 \%$ & Cystobacteraceae & $26 \%$ \\
\hline MIADJ1C10 & Firmicutes & $37 \%$ & Clostridia & $36 \%$ & Clostridiales & $35 \%$ & Lachnospiraceae & $20 \%$ & Catonella & $13 \%$ \\
\hline MIADJ1C11 & Proteobacteria & $100 \%$ & Alphaproteobacteria & $100 \%$ & Rhizobiales & $100 \%$ & Hyphomicrobiaceae & $44 \%$ & Rhodoplanes & $43 \%$ \\
\hline MIADJ1D01 & Acidobacteria & $52 \%$ & Acidobacteria & $52 \%$ & Acidobacteriales & $52 \%$ & Acidobacteriaceae & $52 \%$ & Acidobacterium & $48 \%$ \\
\hline MIADJ1D02 & Acidobacteria & $100 \%$ & Acidobacteria & $100 \%$ & Acidobacteriales & $100 \%$ & Acidobacteriaceae & $100 \%$ & Acidobacterium & $100 \%$ \\
\hline MIADJ1D03 & Proteobacteria & $100 \%$ & Betaproteobacteria & $99 \%$ & Burkholderiales & $98 \%$ & Incertae sedis 5 & $43 \%$ & Tepidimonas & $22 \%$ \\
\hline MIADJ1D04 & Verrucomicrobia & $100 \%$ & Verrucomicrobiae & $100 \%$ & Verrucomicrobiales & $100 \%$ & Verrucomicrobiaceae & $65 \%$ & Verrucomicrobium & $64 \%$ \\
\hline MIADJ1D06 & Acidobacteria & $100 \%$ & Acidobacteria & $100 \%$ & Acidobacteriales & $100 \%$ & Acidobacteriaceae & $100 \%$ & Acidobacterium & $100 \%$ \\
\hline MIADJ1D07 & Verrucomicrobia & $98 \%$ & Verrucomicrobiae & $98 \%$ & Verrucomicrobiales & $98 \%$ & Verrucomicrobiaceae & $50 \%$ & Verrucomicrobium & $50 \%$ \\
\hline MIADJ1D09 & Proteobacteria & $50 \%$ & Deltaproteobacteria & $40 \%$ & Myxococcales & $37 \%$ & Cystobacterineae & $35 \%$ & Cystobacteraceae & $35 \%$ \\
\hline MIADJ1D10 & Firmicutes & $100 \%$ & Bacilli & $100 \%$ & Bacillales & $100 \%$ & Bacillaceae & $100 \%$ & Bacillus & $100 \%$ \\
\hline MIADJ1D11 & Verrucomicrobia & $95 \%$ & Verrucomicrobiae & $95 \%$ & Verrucomicrobiales & $95 \%$ & Verrucomicrobiaceae & $48 \%$ & Verrucomicrobium & $48 \%$ \\
\hline MIADJ1D12 & Firmicutes & $62 \%$ & Clostridia & $56 \%$ & Clostridiales & $56 \%$ & Clostridiaceae & $42 \%$ & Thermobrachium & $13 \%$ \\
\hline MIADJ1E01 & Proteobacteria & $34 \%$ & Deltaproteobacteria & $22 \%$ & Myxococcales & $17 \%$ & Cystobacterineae & $14 \%$ & Cystobacteraceae & $14 \%$ \\
\hline MIADJ1E02 & Acidobacteria & $100 \%$ & Acidobacteria & $100 \%$ & Acidobacteriales & $100 \%$ & Acidobacteriaceae & $100 \%$ & Acidobacterium & $100 \%$ \\
\hline MIADJ1E03 & Actinobacteria & $20 \%$ & Actinobacteria & $20 \%$ & Rubrobacteridae & $14 \%$ & Rubrobacterales & $14 \%$ & Rubrobacterineae & $14 \%$ \\
\hline MIADJ1E04 & Gemmatimonadetes & $36 \%$ & Gemmatimonadetes & $36 \%$ & Gemmatimonadales & $36 \%$ & Gemmatimonadaceae & $36 \%$ & Gemmatimonas & $36 \%$ \\
\hline MIADJ1E05 & Proteobacteria & $42 \%$ & Deltaproteobacteria & $36 \%$ & Myxococcales & $32 \%$ & Cystobacterineae & $30 \%$ & Cystobacteraceae & $30 \%$ \\
\hline MIADJ1E06 & Proteobacteria & $100 \%$ & Betaproteobacteria & $100 \%$ & Burkholderiales & $98 \%$ & Incertae sedis 5 & $37 \%$ & Tepidimonas & $23 \%$ \\
\hline MIADJ1E07 & Acidobacteria & $60 \%$ & Acidobacteria & $60 \%$ & Acidobacteriales & $60 \%$ & Acidobacteriaceae & $60 \%$ & Acidobacterium & $59 \%$ \\
\hline MIADJ1E08 & Planctomycetes & $99 \%$ & Planctomycetacia & $99 \%$ & Planctomycetales & $99 \%$ & Planctomycetaceae & $99 \%$ & Gemmata & $85 \%$ \\
\hline MIADJ1E09 & Proteobacteria & $95 \%$ & Deltaproteobacteria & $93 \%$ & Desulfurellales & $68 \%$ & Desulfurellaceae & $68 \%$ & Hippea & $68 \%$ \\
\hline
\end{tabular}


ANEXO B - Resultados das comparações das seqüências parciais da região 16S rRNA obtidas em amostras de solo Terra Preta Antropogênica e respectivos solos adjacentes da região Amazônica Central e Oriental, com as amostras depositadas no banco de dados de seqüências de 16S rRNA do RDP II pelo programa Classifier

\begin{tabular}{|c|c|c|c|c|c|c|c|c|c|c|}
\hline \multirow{3}{*}{$\frac{\text { Clone }}{\text { MIADJ1E10 }}$} & \multirow{3}{*}{$\begin{array}{c}\text { Filo } \\
\text { Proteobacteria }\end{array}$} & \multirow{2}{*}{\multicolumn{3}{|c|}{ Classe }} & \multirow{2}{*}{\multicolumn{2}{|c|}{ Ordem }} & \multirow{2}{*}{\multicolumn{2}{|c|}{ Família }} & \multirow{2}{*}{\multicolumn{2}{|c|}{ Gênero }} \\
\hline & & & & & & & & & & \\
\hline & & $70 \%$ & Deltaproteobacteria & $66 \%$ & Desulfobacterales & $25 \%$ & Desulfobacteraceae & $21 \%$ & Desulfocella & $18 \%$ \\
\hline MIADJ1E11 & Firmicutes & $32 \%$ & Clostridia & $32 \%$ & Clostridiales & $30 \%$ & Clostridiaceae & $16 \%$ & Acetivibrio & $7 \%$ \\
\hline MIADJ1F02 & Planctomycetes & $95 \%$ & Planctomycetacia & $95 \%$ & Planctomycetales & $95 \%$ & Planctomycetaceae & $95 \%$ & Isosphaera & $59 \%$ \\
\hline MIADJ1F03 & Firmicutes & $100 \%$ & Bacilli & $100 \%$ & Bacillales & $100 \%$ & Bacillaceae & $100 \%$ & Bacillus & $100 \%$ \\
\hline MIADJ1F04 & Firmicutes & $48 \%$ & Clostridia & $47 \%$ & Clostridiales & $47 \%$ & Clostridiaceae & $32 \%$ & Faecalibacterium & $20 \%$ \\
\hline MIADJ1F05 & Proteobacteria & $54 \%$ & Deltaproteobacteria & $29 \%$ & Myxococcales & $24 \%$ & Cystobacterineae & $23 \%$ & Cystobacteraceae & $23 \%$ \\
\hline MIADJ1F06 & Acidobacteria & $100 \%$ & Acidobacteria & $100 \%$ & Acidobacteriales & $100 \%$ & Acidobacteriaceae & $100 \%$ & Acidobacterium & $100 \%$ \\
\hline MIADJ1F07 & Acidobacteria & $100 \%$ & Acidobacteria & $100 \%$ & Acidobacteriales & $100 \%$ & Acidobacteriaceae & $100 \%$ & Acidobacterium & $100 \%$ \\
\hline MIADJ1F08 & Proteobacteria & $44 \%$ & Deltaproteobacteria & $37 \%$ & Myxococcales & $35 \%$ & Cystobacterineae & $34 \%$ & Cystobacteraceae & $33 \%$ \\
\hline MIADJ1F09 & Proteobacteria & $50 \%$ & Deltaproteobacteria & $43 \%$ & Myxococcales & $40 \%$ & Cystobacterineae & $39 \%$ & Cystobacteraceae & $39 \%$ \\
\hline MIADJ1F12 & Acidobacteria & $94 \%$ & Acidobacteria & $94 \%$ & Acidobacteriales & $94 \%$ & Acidobacteriaceae & $94 \%$ & Acidobacterium & $87 \%$ \\
\hline MIADJ1G01 & Proteobacteria & $52 \%$ & Deltaproteobacteria & $46 \%$ & Myxococcales & $43 \%$ & Cystobacterineae & $42 \%$ & Cystobacteraceae & $41 \%$ \\
\hline MIADJ1G02 & Planctomycetes & $100 \%$ & Planctomycetacia & $100 \%$ & Planctomycetales & $100 \%$ & Planctomycetaceae & $100 \%$ & Gemmata & $59 \%$ \\
\hline MIADJ1G03 & Acidobacteria & $100 \%$ & Acidobacteria & $100 \%$ & Acidobacteriales & $100 \%$ & Acidobacteriaceae & $100 \%$ & Acidobacterium & $100 \%$ \\
\hline MIADJ1G04 & Proteobacteria & $47 \%$ & Deltaproteobacteria & $42 \%$ & Myxococcales & $38 \%$ & Cystobacterineae & $37 \%$ & Cystobacteraceae & $36 \%$ \\
\hline MIADJ1G05 & Acidobacteria & $99 \%$ & Acidobacteria & $99 \%$ & Acidobacteriales & $99 \%$ & Acidobacteriaceae & $99 \%$ & Acidobacterium & $99 \%$ \\
\hline MIADJ1G06 & Verrucomicrobia & $91 \%$ & Verrucomicrobiae & $91 \%$ & Verrucomicrobiales & $91 \%$ & Verrucomicrobiaceae & $59 \%$ & Verrucomicrobium & $59 \%$ \\
\hline MIADJ1G08 & Acidobacteria & $98 \%$ & Acidobacteria & $98 \%$ & Acidobacteriales & $98 \%$ & Acidobacteriaceae & $98 \%$ & Acidobacterium & $91 \%$ \\
\hline MIADJ1G11 & Firmicutes & $100 \%$ & Bacilli & $99 \%$ & Bacillales & $96 \%$ & Paenibacillaceae & $85 \%$ & Paenibacillus & $31 \%$ \\
\hline MIADJ1H04 & Verrucomicrobia & $92 \%$ & Verrucomicrobiae & $92 \%$ & Verrucomicrobiales & $92 \%$ & Verrucomicrobiaceae & $40 \%$ & Verrucomicrobium & $39 \%$ \\
\hline MIADJ1H05 & Verrucomicrobia & $82 \%$ & Verrucomicrobiae & $82 \%$ & Verrucomicrobiales & $82 \%$ & Verrucomicrobiaceae & $41 \%$ & Verrucomicrobium & $41 \%$ \\
\hline MIADJ1H07 & Proteobacteria & $85 \%$ & Deltaproteobacteria & $78 \%$ & Syntrophobacterales & $58 \%$ & Syntrophaceae & $35 \%$ & Smithella & $33 \%$ \\
\hline MIADJ1H08 & Verrucomicrobia & $80 \%$ & Verrucomicrobiae & $80 \%$ & Verrucomicrobiales & $80 \%$ & Verrucomicrobiaceae & $49 \%$ & Verrucomicrobium & $49 \%$ \\
\hline MIADJ1H10 & Acidobacteria & $98 \%$ & Acidobacteria & $98 \%$ & Acidobacteriales & $98 \%$ & Acidobacteriaceae & $98 \%$ & Acidobacterium & $98 \%$ \\
\hline MIADJ1H11 & Proteobacteria & $76 \%$ & Gammaproteobacteria & $42 \%$ & Chromatiales & $39 \%$ & Chromatiaceae & $35 \%$ & Chromatium & $18 \%$ \\
\hline MIADJ2A01 & Proteobacteria & $85 \%$ & Deltaproteobacteria & $83 \%$ & Desulfurellales & $49 \%$ & Desulfurellaceae & $49 \%$ & Hippea & $49 \%$ \\
\hline MIADJ2A02 & Proteobacteria & $52 \%$ & Deltaproteobacteria & $48 \%$ & Myxococcales & $39 \%$ & Cystobacterineae & $30 \%$ & Cystobacteraceae & $30 \%$ \\
\hline MIADJ2A03 & Acidobacteria & $53 \%$ & Acidobacteria & $53 \%$ & Acidobacteriales & $53 \%$ & Acidobacteriaceae & $53 \%$ & Acidobacterium & $45 \%$ \\
\hline MIADJ2A04 & Acidobacteria & $96 \%$ & Acidobacteria & $96 \%$ & Acidobacteriales & $96 \%$ & Acidobacteriaceae & $96 \%$ & Acidobacterium & $95 \%$ \\
\hline MIADJ2A05 & Firmicutes & $44 \%$ & Clostridia & $43 \%$ & Clostridiales & $36 \%$ & Clostridiaceae & $23 \%$ & Acetanaerobacterium & $9 \%$ \\
\hline MIADJ2A06 & Acidobacteria & $100 \%$ & Acidobacteria & $100 \%$ & Acidobacteriales & $100 \%$ & Acidobacteriaceae & $100 \%$ & Acidobacterium & $100 \%$ \\
\hline MIADJ2A07 & Proteobacteria & $100 \%$ & Alphaproteobacteria & $100 \%$ & Rhizobiales & $100 \%$ & Hyphomicrobiaceae & $40 \%$ & Rhodoplanes & $33 \%$ \\
\hline MIADJ2A08 & Firmicutes & $61 \%$ & Clostridia & $61 \%$ & Clostridiales & $58 \%$ & Clostridiaceae & $42 \%$ & Acetanaerobacterium & $26 \%$ \\
\hline MIADJ2A09 & Proteobacteria & $52 \%$ & Deltaproteobacteria & $46 \%$ & Myxococcales & $39 \%$ & Cystobacterineae & $36 \%$ & Cystobacteraceae & $35 \%$ \\
\hline
\end{tabular}


ANEXO B - Resultados das comparações das seqüências parciais da região 16S rRNA obtidas em amostras de solo Terra Preta Antropogênica e respectivos solos adjacentes da região Amazônica Central e Oriental, com as amostras depositadas no banco de dados de seqüências de 16S rRNA do RDP II pelo programa Classifier

\begin{tabular}{|c|c|c|c|c|c|c|c|c|c|c|}
\hline Clone & Filo & & Classe & & Ordem & & Família & & Gênero & \\
\hline MIADJ2A10 & Firmicutes & $49 \%$ & Clostridia & $48 \%$ & Clostridiales & $40 \%$ & Clostridiaceae & $36 \%$ & Faecalibacterium & $21 \%$ \\
\hline MIADJ2A11 & Actinobacteria & $96 \%$ & Actinobacteria & $96 \%$ & Actinobacteridae & $73 \%$ & Actinomycetales & $73 \%$ & Frankineae & $28 \%$ \\
\hline MIADJ2A12 & Verrucomicrobia & $68 \%$ & Verrucomicrobiae & $68 \%$ & Verrucomicrobiales & $68 \%$ & Verrucomicrobiaceae & $35 \%$ & Verrucomicrobium & $34 \%$ \\
\hline MIADJ2B01 & Proteobacteria & $61 \%$ & Deltaproteobacteria & $54 \%$ & Myxococcales & $51 \%$ & Cystobacterineae & $33 \%$ & Cystobacteraceae & $33 \%$ \\
\hline MIADJ2B02 & Proteobacteria & $91 \%$ & Deltaproteobacteria & $86 \%$ & Desulfurellales & $48 \%$ & Desulfurellaceae & $48 \%$ & Hippea & $48 \%$ \\
\hline MIADJ2B03 & Thermodesulfobacteria & $33 \%$ & Thermodesulfobacteria & $33 \%$ & Thermodesulfobacteriales & $33 \%$ & Thermodesulfobacteriaceae & $33 \%$ & Thermodesulfatator & $33 \%$ \\
\hline MIADJ2B04 & Acidobacteria & $100 \%$ & Acidobacteria & $100 \%$ & Acidobacteriales & $100 \%$ & Acidobacteriaceae & $100 \%$ & Acidobacterium & $100 \%$ \\
\hline MIADJ2B05 & Acidobacteria & $84 \%$ & Acidobacteria & $84 \%$ & Acidobacteriales & $84 \%$ & Acidobacteriaceae & $84 \%$ & Acidobacterium & $82 \%$ \\
\hline MIADJ2B06 & Proteobacteria & $39 \%$ & Deltaproteobacteria & $29 \%$ & Myxococcales & $28 \%$ & Cystobacterineae & $26 \%$ & Cystobacteraceae & $26 \%$ \\
\hline MIADJ2B07 & Firmicutes & $100 \%$ & Bacilli & $100 \%$ & Bacillales & $100 \%$ & Bacillaceae & $99 \%$ & Bacillus & $99 \%$ \\
\hline MIADJ2B08 & Acidobacteria & $100 \%$ & Acidobacteria & $100 \%$ & Acidobacteriales & $100 \%$ & Acidobacteriaceae & $100 \%$ & Acidobacterium & $100 \%$ \\
\hline MIADJ2B09 & Firmicutes & $100 \%$ & Bacilli & $100 \%$ & Bacillales & $100 \%$ & Bacillaceae & $100 \%$ & Bacillus & $100 \%$ \\
\hline MIADJ2B10 & Acidobacteria & $100 \%$ & Acidobacteria & $100 \%$ & Acidobacteriales & $100 \%$ & Acidobacteriaceae & $100 \%$ & Acidobacterium & $100 \%$ \\
\hline MIADJ2B11 & Actinobacteria & $52 \%$ & Actinobacteria & $52 \%$ & Rubrobacteridae & $41 \%$ & Rubrobacterales & $41 \%$ & Rubrobacterineae & $41 \%$ \\
\hline MIADJ2B12 & Proteobacteria & $100 \%$ & Alphaproteobacteria & $100 \%$ & Rhizobiales & $100 \%$ & Methylobacteriaceae & $30 \%$ & Microvirga & $30 \%$ \\
\hline MIADJ2C01 & Proteobacteria & $68 \%$ & Deltaproteobacteria & $54 \%$ & Syntrophobacterales & $30 \%$ & Syntrophobacteraceae & $21 \%$ & Desulforhabdus & $13 \%$ \\
\hline MIADJ2C02 & Proteobacteria & $52 \%$ & Deltaproteobacteria & $47 \%$ & Myxococcales & $47 \%$ & Cystobacterineae & $40 \%$ & Cystobacteraceae & $39 \%$ \\
\hline MIADJ2C05 & Proteobacteria & $75 \%$ & Deltaproteobacteria & $72 \%$ & Desulfurellales & $39 \%$ & Desulfurellaceae & $39 \%$ & Hippea & $39 \%$ \\
\hline MIADJ2C06 & Acidobacteria & $55 \%$ & Acidobacteria & $55 \%$ & Acidobacteriales & $55 \%$ & Acidobacteriaceae & $55 \%$ & Acidobacterium & $50 \%$ \\
\hline MIADJ2C07 & Proteobacteria & $46 \%$ & Deltaproteobacteria & $39 \%$ & Myxococcales & $36 \%$ & Cystobacterineae & $34 \%$ & Cystobacteraceae & $31 \%$ \\
\hline MIADJ2C08 & Acidobacteria & $100 \%$ & Acidobacteria & $100 \%$ & Acidobacteriales & $100 \%$ & Acidobacteriaceae & $100 \%$ & Acidobacterium & $100 \%$ \\
\hline MIADJ2C09 & Proteobacteria & $49 \%$ & Deltaproteobacteria & $37 \%$ & Myxococcales & $35 \%$ & Cystobacterineae & $31 \%$ & Cystobacteraceae & $31 \%$ \\
\hline MIADJ2C10 & Proteobacteria & $82 \%$ & Deltaproteobacteria & $72 \%$ & Desulfobacterales & $22 \%$ & Desulfobacteraceae & $21 \%$ & Desulforegula & $19 \%$ \\
\hline MIADJ2C11 & Firmicutes & $48 \%$ & Clostridia & $47 \%$ & Clostridiales & $43 \%$ & Lachnospiraceae & $21 \%$ & Catonella & $16 \%$ \\
\hline MIADJ2C12 & Acidobacteria & $100 \%$ & Acidobacteria & $100 \%$ & Acidobacteriales & $100 \%$ & Acidobacteriaceae & $100 \%$ & Acidobacterium & $100 \%$ \\
\hline MIADJ2D01 & Firmicutes & $43 \%$ & Clostridia & $43 \%$ & Clostridiales & $43 \%$ & Lachnospiraceae & $18 \%$ & Oribacterium & $10 \%$ \\
\hline MIADJ2D02 & Proteobacteria & $100 \%$ & Betaproteobacteria & $100 \%$ & Burkholderiales & $100 \%$ & Burkholderiaceae & $100 \%$ & Burkholderia & $100 \%$ \\
\hline MIADJ2D03 & Proteobacteria & $38 \%$ & Deltaproteobacteria & $29 \%$ & Myxococcales & $27 \%$ & Cystobacterineae & $16 \%$ & Cystobacteraceae & $16 \%$ \\
\hline MIADJ2D04 & Proteobacteria & $39 \%$ & Deltaproteobacteria & $32 \%$ & Myxococcales & $28 \%$ & Cystobacterineae & $22 \%$ & Cystobacteraceae & $22 \%$ \\
\hline MIADJ2D05 & Proteobacteria & $54 \%$ & Betaproteobacteria & $31 \%$ & Burkholderiales & $19 \%$ & Alcaligenaceae & $10 \%$ & Sutterella & $10 \%$ \\
\hline MIADJ2D07 & Proteobacteria & $100 \%$ & Alphaproteobacteria & $100 \%$ & Rhizobiales & $93 \%$ & Beijerinckiaceae & $63 \%$ & Methylocapsa & $28 \%$ \\
\hline MIADJ2D08 & Proteobacteria & $45 \%$ & Deltaproteobacteria & $30 \%$ & Myxococcales & $20 \%$ & Cystobacterineae & $20 \%$ & Cystobacteraceae & $20 \%$ \\
\hline MIADJ2D09 & Firmicutes & $45 \%$ & Clostridia & $44 \%$ & Clostridiales & $38 \%$ & Clostridiaceae & $24 \%$ & Thermobrachium & $13 \%$ \\
\hline MIADJ2D10 & Acidobacteria & $37 \%$ & Acidobacteria & $37 \%$ & Acidobacteriales & $37 \%$ & Acidobacteriaceae & $37 \%$ & Acidobacterium & $37 \%$ \\
\hline
\end{tabular}


ANEXO B - Resultados das comparações das seqüências parciais da região 16S rRNA obtidas em amostras de solo Terra Preta Antropogênica e respectivos solos adjacentes da região Amazônica Central e Oriental, com as amostras depositadas no banco de dados de seqüências de 16S rRNA do RDP II pelo programa Classifier

\begin{tabular}{|c|c|c|c|c|c|c|c|c|c|c|}
\hline Clone & Filo & & Classe & & Ordem & & Família & & Gênero & \\
\hline MIADJ2D11 & Firmicutes & $52 \%$ & Clostridia & $52 \%$ & Clostridiales & $52 \%$ & Lachnospiraceae & $21 \%$ & Catonella & $11 \%$ \\
\hline MIADJ2D12 & Firmicutes & $100 \%$ & Bacilli & $100 \%$ & Bacillales & $100 \%$ & Paenibacillaceae & $95 \%$ & Paenibacillus & $91 \%$ \\
\hline MIADJ2E01 & Gemmatimonadetes & $80 \%$ & Gemmatimonadetes & $80 \%$ & Gemmatimonadales & $80 \%$ & Gemmatimonadaceae & $80 \%$ & Gemmatimonas & $80 \%$ \\
\hline MIADJ2E03 & Proteobacteria & $92 \%$ & Deltaproteobacteria & $92 \%$ & Desulfurellales & $59 \%$ & Desulfurellaceae & $59 \%$ & Hippea & $59 \%$ \\
\hline MIADJ2E04 & Firmicutes & $41 \%$ & Clostridia & $39 \%$ & Clostridiales & $37 \%$ & Clostridiaceae & $26 \%$ & Acetanaerobacterium & $11 \%$ \\
\hline MIADJ2E05 & Nitrospira & $100 \%$ & Nitrospira & $100 \%$ & Nitrospirales & $100 \%$ & Nitrospiraceae & $100 \%$ & Nitrospira & $100 \%$ \\
\hline MIADJ2E06 & Acidobacteria & $100 \%$ & Acidobacteria & $100 \%$ & Acidobacteriales & $100 \%$ & Acidobacteriaceae & $100 \%$ & Acidobacterium & $100 \%$ \\
\hline MIADJ2E08 & Proteobacteria & $38 \%$ & Deltaproteobacteria & $29 \%$ & Myxococcales & $26 \%$ & Cystobacterineae & $22 \%$ & Cystobacteraceae & $22 \%$ \\
\hline MIADJ2E12 & Firmicutes & $31 \%$ & Clostridia & $28 \%$ & Clostridiales & $19 \%$ & Peptococcaceae & $13 \%$ & Cryptanaerobacter & $6 \%$ \\
\hline MIADJ2F01 & Proteobacteria & $34 \%$ & Deltaproteobacteria & $26 \%$ & Myxococcales & $14 \%$ & Cystobacterineae & $13 \%$ & Cystobacteraceae & $13 \%$ \\
\hline MIADJ2F02 & Acidobacteria & $96 \%$ & Acidobacteria & $96 \%$ & Acidobacteriales & $96 \%$ & Acidobacteriaceae & $96 \%$ & Acidobacterium & $95 \%$ \\
\hline MIADJ2F03 & Verrucomicrobia & $84 \%$ & Verrucomicrobiae & $84 \%$ & Verrucomicrobiales & $84 \%$ & Opitutaceae & $59 \%$ & Opitutus & $59 \%$ \\
\hline MIADJ2F04 & Proteobacteria & $100 \%$ & Alphaproteobacteria & $100 \%$ & Rhizobiales & $100 \%$ & Hyphomicrobiaceae & $50 \%$ & Rhodoplanes & $49 \%$ \\
\hline MIADJ2F07 & Acidobacteria & $100 \%$ & Acidobacteria & $100 \%$ & Acidobacteriales & $100 \%$ & Acidobacteriaceae & $100 \%$ & Acidobacterium & $100 \%$ \\
\hline MIADJ2F08 & Proteobacteria & $35 \%$ & Deltaproteobacteria & $31 \%$ & Myxococcales & $29 \%$ & Cystobacterineae & $25 \%$ & Cystobacteraceae & $25 \%$ \\
\hline MIADJ2F09 & Proteobacteria & $39 \%$ & Deltaproteobacteria & $34 \%$ & Myxococcales & $29 \%$ & Cystobacterineae & $28 \%$ & Cystobacteraceae & $28 \%$ \\
\hline MIADJ2F10 & Acidobacteria & $100 \%$ & Acidobacteria & $100 \%$ & Acidobacteriales & $100 \%$ & Acidobacteriaceae & $100 \%$ & Acidobacterium & $100 \%$ \\
\hline MIADJ2F 12 & Proteobacteria & $96 \%$ & Gammaproteobacteria & $81 \%$ & Oceanospirillales & $35 \%$ & Hahellaceae & $29 \%$ & Zooshikella & $28 \%$ \\
\hline MIADJ2G01 & Proteobacteria & $100 \%$ & Betaproteobacteria & $100 \%$ & Burkholderiales & $99 \%$ & Comamonadaceae & $50 \%$ & Caldimonas & $27 \%$ \\
\hline MIADJ2G02 & Acidobacteria & $100 \%$ & Acidobacteria & $100 \%$ & Acidobacteriales & $100 \%$ & Acidobacteriaceae & $100 \%$ & Acidobacterium & $100 \%$ \\
\hline MIADJ2G03 & Verrucomicrobia & $51 \%$ & Verrucomicrobiae & $51 \%$ & Verrucomicrobiales & $51 \%$ & Verrucomicrobiaceae & $42 \%$ & Verrucomicrobium & $42 \%$ \\
\hline MIADJ2G04 & Proteobacteria & $100 \%$ & Alphaproteobacteria & $100 \%$ & Rhodospirillales & $100 \%$ & Acetobacteraceae & $100 \%$ & Acidisphaera & $85 \%$ \\
\hline MIADJ2G05 & Firmicutes & $47 \%$ & Clostridia & $47 \%$ & Clostridiales & $45 \%$ & Clostridiaceae & $31 \%$ & Acetanaerobacterium & $20 \%$ \\
\hline MIADJ2G06 & Proteobacteria & $48 \%$ & Betaproteobacteria & $12 \%$ & Burkholderiales & $6 \%$ & Comamonadaceae & $3 \%$ & Ottowia & $2 \%$ \\
\hline MIADJ2G08 & Firmicutes & $100 \%$ & Bacilli & $100 \%$ & Bacillales & $100 \%$ & Bacillaceae & $100 \%$ & Bacillus & $100 \%$ \\
\hline MIADJ2G10 & Acidobacteria & $100 \%$ & Acidobacteria & $100 \%$ & Acidobacteriales & $100 \%$ & Acidobacteriaceae & $100 \%$ & Acidobacterium & $100 \%$ \\
\hline MIADJ2G11 & Proteobacteria & $53 \%$ & Deltaproteobacteria & $46 \%$ & Myxococcales & $43 \%$ & Cystobacterineae & $29 \%$ & Cystobacteraceae & $29 \%$ \\
\hline MIADJ2H01 & Acidobacteria & $100 \%$ & Acidobacteria & $100 \%$ & Acidobacteriales & $100 \%$ & Acidobacteriaceae & $100 \%$ & Acidobacterium & $100 \%$ \\
\hline MIADJ2H02 & Proteobacteria & $82 \%$ & Deltaproteobacteria & $66 \%$ & Desulfobacterales & $41 \%$ & Desulfobacteraceae & $40 \%$ & Desulforegula & $30 \%$ \\
\hline MIADJ2H03 & Proteobacteria & $41 \%$ & Deltaproteobacteria & $33 \%$ & Myxococcales & $32 \%$ & Cystobacterineae & $32 \%$ & Cystobacteraceae & $32 \%$ \\
\hline MIADJ2H04 & Firmicutes & $100 \%$ & Bacilli & $100 \%$ & Bacillales & $100 \%$ & Bacillaceae & $100 \%$ & Bacillus & $97 \%$ \\
\hline MIADJ2H05 & Proteobacteria & $100 \%$ & Alphaproteobacteria & $100 \%$ & Rhizobiales & $98 \%$ & Methylobacteriaceae & $67 \%$ & Microvirga & $66 \%$ \\
\hline MIADJ2H06 & Proteobacteria & $42 \%$ & Deltaproteobacteria & $39 \%$ & Myxococcales & $37 \%$ & Cystobacterineae & $34 \%$ & Cystobacteraceae & $32 \%$ \\
\hline MIADJ2H10 & Firmicutes & $29 \%$ & Clostridia & $27 \%$ & Clostridiales & $15 \%$ & Peptococcaceae & $9 \%$ & Cryptanaerobacter & $5 \%$ \\
\hline
\end{tabular}


ANEXO B - Resultados das comparações das seqüências parciais da região 16S rRNA obtidas em amostras de solo Terra Preta Antropogênica e respectivos solos adjacentes da região Amazônica Central e Oriental, com as amostras depositadas no banco de dados de seqüências de 16S rRNA do RDP II pelo programa Classifier

\begin{tabular}{|c|c|c|c|c|c|c|c|c|c|c|}
\hline Clone & Filo & & Classe & & Ordem & & Família & & Gênero & \\
\hline MIADJ3A01 & Acidobacteria & $99 \%$ & Acidobacteria & $99 \%$ & Acidobacteriales & $99 \%$ & Acidobacteriaceae & $99 \%$ & Acidobacterium & $99 \%$ \\
\hline MIADJ3A02 & Acidobacteria & $100 \%$ & Acidobacteria & $100 \%$ & Acidobacteriales & $100 \%$ & Acidobacteriaceae & $100 \%$ & Acidobacterium & $100 \%$ \\
\hline MIADJ3A04 & Acidobacteria & $67 \%$ & Acidobacteria & $67 \%$ & Acidobacteriales & $67 \%$ & Acidobacteriaceae & $67 \%$ & Acidobacterium & $65 \%$ \\
\hline MIADJ3A05 & Proteobacteria & $51 \%$ & Alphaproteobacteria & $27 \%$ & Rhodospirillales & $20 \%$ & Acetobacteraceae & $14 \%$ & Craurococcus & $7 \%$ \\
\hline MIADJ3A06 & Acidobacteria & $100 \%$ & Acidobacteria & $100 \%$ & Acidobacteriales & $100 \%$ & Acidobacteriaceae & $100 \%$ & Acidobacterium & $100 \%$ \\
\hline MIADJ3A07 & Acidobacteria & $95 \%$ & Acidobacteria & $95 \%$ & Acidobacteriales & $95 \%$ & Acidobacteriaceae & $95 \%$ & Acidobacterium & $92 \%$ \\
\hline MIADJ3A08 & Acidobacteria & $100 \%$ & Acidobacteria & $100 \%$ & Acidobacteriales & $100 \%$ & Acidobacteriaceae & $100 \%$ & Acidobacterium & $99 \%$ \\
\hline MIADJ3A09 & Acidobacteria & $30 \%$ & Acidobacteria & $30 \%$ & Acidobacteriales & $30 \%$ & Acidobacteriaceae & $30 \%$ & Holophaga & $13 \%$ \\
\hline MIADJ3A10 & Proteobacteria & $49 \%$ & Deltaproteobacteria & $36 \%$ & Myxococcales & $30 \%$ & Cystobacterineae & $23 \%$ & Cystobacteraceae & $23 \%$ \\
\hline MIADJ3A11 & Acidobacteria & $98 \%$ & Acidobacteria & $98 \%$ & Acidobacteriales & $98 \%$ & Acidobacteriaceae & $98 \%$ & Acidobacterium & $96 \%$ \\
\hline MIADJ3A12 & Proteobacteria & $40 \%$ & Deltaproteobacteria & $19 \%$ & Desulfobacterales & $11 \%$ & Desulfobacteraceae & $11 \%$ & Desulforegula & $9 \%$ \\
\hline MIADJ3B01 & Acidobacteria & $67 \%$ & Acidobacteria & $67 \%$ & Acidobacteriales & $67 \%$ & Acidobacteriaceae & $67 \%$ & Acidobacterium & $66 \%$ \\
\hline MIADJ3B02 & Firmicutes & $60 \%$ & Clostridia & $57 \%$ & Thermoanaerobacteriales & $37 \%$ & Thermoanaerobacteriaceae & $24 \%$ & Thermanaeromonas & $12 \%$ \\
\hline MIADJ3B03 & Acidobacteria & $99 \%$ & Acidobacteria & $99 \%$ & Acidobacteriales & $99 \%$ & Acidobacteriaceae & $99 \%$ & Acidobacterium & $98 \%$ \\
\hline MIADJ3B04 & Acidobacteria & $53 \%$ & Acidobacteria & $53 \%$ & Acidobacteriales & $53 \%$ & Acidobacteriaceae & $53 \%$ & Acidobacterium & $52 \%$ \\
\hline MIADJ3B05 & Proteobacteria & $100 \%$ & Betaproteobacteria & $87 \%$ & Burkholderiales & $74 \%$ & Incertae sedis 5 & $30 \%$ & Thiobacter & $30 \%$ \\
\hline MIADJ3B06 & Proteobacteria & $55 \%$ & Deltaproteobacteria & $37 \%$ & Myxococcales & $28 \%$ & Cystobacterineae & $28 \%$ & Cystobacteraceae & $28 \%$ \\
\hline MIADJ3B08 & Proteobacteria & $100 \%$ & Deltaproteobacteria & $100 \%$ & Myxococcales & $100 \%$ & Cystobacterineae & $100 \%$ & Cystobacteraceae & $100 \%$ \\
\hline MIADJ3B09 & Proteobacteria & $43 \%$ & Deltaproteobacteria & $34 \%$ & Desulfurellales & $32 \%$ & Desulfurellaceae & $32 \%$ & Hippea & $32 \%$ \\
\hline MIADJ3B10 & Acidobacteria & $69 \%$ & Acidobacteria & $69 \%$ & Acidobacteriales & $69 \%$ & Acidobacteriaceae & $69 \%$ & Acidobacterium & $68 \%$ \\
\hline MIADJ3B11 & Proteobacteria & $100 \%$ & Betaproteobacteria & $96 \%$ & Burkholderiales & $90 \%$ & Comamonadaceae & $50 \%$ & Xenophilus & $39 \%$ \\
\hline MIADJ3B12 & Acidobacteria & $36 \%$ & Acidobacteria & $36 \%$ & Acidobacteriales & $36 \%$ & Acidobacteriaceae & $36 \%$ & Acidobacterium & $36 \%$ \\
\hline MIADJ3C01 & Acidobacteria & $66 \%$ & Acidobacteria & $66 \%$ & Acidobacteriales & $66 \%$ & Acidobacteriaceae & $66 \%$ & Acidobacterium & $65 \%$ \\
\hline MIADJ3C02 & Proteobacteria & $100 \%$ & Gammaproteobacteria & $76 \%$ & Chromatiales & $62 \%$ & Ectothiorhodospiraceae & $32 \%$ & Nitrococcus & $21 \%$ \\
\hline MIADJ3C03 & Proteobacteria & $30 \%$ & Deltaproteobacteria & $21 \%$ & Myxococcales & $18 \%$ & Cystobacterineae & $12 \%$ & Cystobacteraceae & $11 \%$ \\
\hline MIADJ3C04 & Proteobacteria & $50 \%$ & Deltaproteobacteria & $38 \%$ & Desulfovibrionales & $18 \%$ & Desulfovibrionaceae & $17 \%$ & Lawsonia & $17 \%$ \\
\hline MIADJ3C07 & Acidobacteria & $100 \%$ & Acidobacteria & $100 \%$ & Acidobacteriales & $100 \%$ & Acidobacteriaceae & $100 \%$ & Acidobacterium & $100 \%$ \\
\hline MIADJ3C08 & Acidobacteria & $100 \%$ & Acidobacteria & $100 \%$ & Acidobacteriales & $100 \%$ & Acidobacteriaceae & $100 \%$ & Acidobacterium & $98 \%$ \\
\hline MIADJ3C09 & Acidobacteria & $99 \%$ & Acidobacteria & $99 \%$ & Acidobacteriales & $99 \%$ & Acidobacteriaceae & $99 \%$ & Acidobacterium & $96 \%$ \\
\hline MIADJ3C 10 & Acidobacteria & $100 \%$ & Acidobacteria & $100 \%$ & Acidobacteriales & $100 \%$ & Acidobacteriaceae & $100 \%$ & Acidobacterium & $99 \%$ \\
\hline MIADJ3C11 & Proteobacteria & $40 \%$ & Deltaproteobacteria & $24 \%$ & Myxococcales & $24 \%$ & Cystobacterineae & $17 \%$ & Cystobacteraceae & $17 \%$ \\
\hline MIADJ3C12 & Acidobacteria & $45 \%$ & Acidobacteria & $45 \%$ & Acidobacteriales & $45 \%$ & Acidobacteriaceae & $45 \%$ & Acidobacterium & $41 \%$ \\
\hline MIADJ3D01 & Acidobacteria & $59 \%$ & Acidobacteria & $59 \%$ & Acidobacteriales & $59 \%$ & Acidobacteriaceae & $59 \%$ & Acidobacterium & $54 \%$ \\
\hline MIADJ3D02 & Acidobacteria & $97 \%$ & Acidobacteria & $97 \%$ & Acidobacteriales & $97 \%$ & Acidobacteriaceae & $97 \%$ & Acidobacterium & $97 \%$ \\
\hline
\end{tabular}


ANEXO B - Resultados das comparações das seqüências parciais da região 16S rRNA obtidas em amostras de solo Terra Preta Antropogênica e respectivos solos adjacentes da região Amazônica Central e Oriental, com as amostras depositadas no banco de dados de seqüências de 16S rRNA do RDP II pelo programa Classifier

\begin{tabular}{|c|c|c|c|c|c|c|c|c|c|c|}
\hline Clone & Filo & & Classe & & Ordem & & Família & & Gênero & \\
\hline MIADJ3D03 & Proteobacteria & $96 \%$ & Deltaproteobacteria & $93 \%$ & Syntrophobacterales & $66 \%$ & Syntrophaceae & $38 \%$ & Desulfobacca & $35 \%$ \\
\hline MIADJ3D04 & Acidobacteria & $100 \%$ & Acidobacteria & $100 \%$ & Acidobacteriales & $100 \%$ & Acidobacteriaceae & $100 \%$ & Acidobacterium & $100 \%$ \\
\hline MIADJ3D05 & Acidobacteria & $99 \%$ & Acidobacteria & $99 \%$ & Acidobacteriales & $99 \%$ & Acidobacteriaceae & $99 \%$ & Acidobacterium & $99 \%$ \\
\hline MIADJ3D06 & Spirochaetes & $35 \%$ & Spirochaetes & $35 \%$ & Spirochaetales & $35 \%$ & Leptospiraceae & $35 \%$ & Leptonema & $35 \%$ \\
\hline MIADJ3D07 & Proteobacteria & $43 \%$ & Betaproteobacteria & $15 \%$ & Hydrogenophilales & $11 \%$ & Hydrogenophilaceae & $11 \%$ & Hydrogenophilus & $11 \%$ \\
\hline MIADJ3D08 & Acidobacteria & $42 \%$ & Acidobacteria & $42 \%$ & Acidobacteriales & $42 \%$ & Acidobacteriaceae & $42 \%$ & Acidobacterium & $40 \%$ \\
\hline MIADJ3D09 & Acidobacteria & $51 \%$ & Acidobacteria & $51 \%$ & Acidobacteriales & $51 \%$ & Acidobacteriaceae & $51 \%$ & Acidobacterium & $45 \%$ \\
\hline MIADJ3D10 & Acidobacteria & $88 \%$ & Acidobacteria & $88 \%$ & Acidobacteriales & $88 \%$ & Acidobacteriaceae & $88 \%$ & Acidobacterium & $86 \%$ \\
\hline MIADJ3D11 & Acidobacteria & $100 \%$ & Acidobacteria & $100 \%$ & Acidobacteriales & $100 \%$ & Acidobacteriaceae & $100 \%$ & Acidobacterium & $100 \%$ \\
\hline MIADJ3D12 & Acidobacteria & $98 \%$ & Acidobacteria & $98 \%$ & Acidobacteriales & $98 \%$ & Acidobacteriaceae & $98 \%$ & Acidobacterium & $97 \%$ \\
\hline MIADJ3E01 & Acidobacteria & $99 \%$ & Acidobacteria & $99 \%$ & Acidobacteriales & $99 \%$ & Acidobacteriaceae & $99 \%$ & Acidobacterium & $99 \%$ \\
\hline MIADJ3E02 & Acidobacteria & $32 \%$ & Acidobacteria & $32 \%$ & Acidobacteriales & $32 \%$ & Acidobacteriaceae & $32 \%$ & Holophaga & $26 \%$ \\
\hline MIADJ3E03 & Acidobacteria & $50 \%$ & Acidobacteria & $50 \%$ & Acidobacteriales & $50 \%$ & Acidobacteriaceae & $50 \%$ & Acidobacterium & $49 \%$ \\
\hline MIADJ3E04 & Proteobacteria & $36 \%$ & Deltaproteobacteria & $16 \%$ & Syntrophobacterales & $13 \%$ & Syntrophobacteraceae & $13 \%$ & Desulfovirga & $9 \%$ \\
\hline MIADJ3E05 & Proteobacteria & $54 \%$ & Deltaproteobacteria & $21 \%$ & Myxococcales & $20 \%$ & Cystobacterineae & $20 \%$ & Cystobacteraceae & $18 \%$ \\
\hline MIADJ3E07 & Acidobacteria & $100 \%$ & Acidobacteria & $100 \%$ & Acidobacteriales & $100 \%$ & Acidobacteriaceae & $100 \%$ & Acidobacterium & $100 \%$ \\
\hline MIADJ3E08 & Acidobacteria & $65 \%$ & Acidobacteria & $65 \%$ & Acidobacteriales & $65 \%$ & Acidobacteriaceae & $65 \%$ & Acidobacterium & $64 \%$ \\
\hline MIADJ3E10 & Acidobacteria & $58 \%$ & Acidobacteria & $58 \%$ & Acidobacteriales & $58 \%$ & Acidobacteriaceae & $58 \%$ & Acidobacterium & $54 \%$ \\
\hline MIADJ3E12 & Acidobacteria & $100 \%$ & Acidobacteria & $100 \%$ & Acidobacteriales & $100 \%$ & Acidobacteriaceae & $100 \%$ & Acidobacterium & $99 \%$ \\
\hline MIADJ3F01 & Proteobacteria & $100 \%$ & Betaproteobacteria & $99 \%$ & Burkholderiales & $89 \%$ & Burkholderiaceae & $32 \%$ & Paucimonas & $21 \%$ \\
\hline MIADJ3F02 & Proteobacteria & $100 \%$ & Alphaproteobacteria & $100 \%$ & Rhizobiales & $100 \%$ & Bradyrhizobiaceae & $28 \%$ & Nitrobacter & $22 \%$ \\
\hline MIADJ3F03 & Acidobacteria & $100 \%$ & Acidobacteria & $100 \%$ & Acidobacteriales & $100 \%$ & Acidobacteriaceae & $100 \%$ & Acidobacterium & $100 \%$ \\
\hline MIADJ3F05 & Proteobacteria & $48 \%$ & Deltaproteobacteria & $35 \%$ & Syntrophobacterales & $27 \%$ & Syntrophobacteraceae & $27 \%$ & Desulforhabdus & $16 \%$ \\
\hline MIADJ3F06 & Proteobacteria & $41 \%$ & Alphaproteobacteria & $27 \%$ & Rhodospirillales & $18 \%$ & Acetobacteraceae & $14 \%$ & Craurococcus & $7 \%$ \\
\hline MIADJ3F09 & Acidobacteria & $59 \%$ & Acidobacteria & $59 \%$ & Acidobacteriales & $59 \%$ & Acidobacteriaceae & $59 \%$ & Acidobacterium & $58 \%$ \\
\hline MIADJ3F10 & Proteobacteria & $44 \%$ & Epsilonproteobacteria & $12 \%$ & Nautiliales & $12 \%$ & Nautiliaceae & $12 \%$ & Lebetimonas & $10 \%$ \\
\hline MIADJ3F11 & Proteobacteria & $34 \%$ & Gammaproteobacteria & $22 \%$ & Xanthomonadales & $10 \%$ & Xanthomonadaceae & $10 \%$ & Nevskia & $5 \%$ \\
\hline MIADJ3F12 & Proteobacteria & $100 \%$ & Alphaproteobacteria & $100 \%$ & Rhizobiales & $100 \%$ & Hyphomicrobiaceae & $48 \%$ & Rhodoplanes & $44 \%$ \\
\hline MIADJ3G01 & Firmicutes & $35 \%$ & Clostridia & $34 \%$ & Clostridiales & $30 \%$ & Clostridiaceae & $20 \%$ & Thermobrachium & $7 \%$ \\
\hline MIADJ3G02 & Acidobacteria & $84 \%$ & Acidobacteria & $84 \%$ & Acidobacteriales & $84 \%$ & Acidobacteriaceae & $84 \%$ & Holophaga & $46 \%$ \\
\hline MIADJ3G03 & Acidobacteria & $82 \%$ & Acidobacteria & $82 \%$ & Acidobacteriales & $82 \%$ & Acidobacteriaceae & $82 \%$ & Holophaga & $50 \%$ \\
\hline MIADJ3G04 & Firmicutes & $58 \%$ & Clostridia & $58 \%$ & Clostridiales & $57 \%$ & Heliobacteriaceae & $23 \%$ & Heliophilum & $21 \%$ \\
\hline MIADJ3G05 & Acidobacteria & $97 \%$ & Acidobacteria & $97 \%$ & Acidobacteriales & $97 \%$ & Acidobacteriaceae & $97 \%$ & Acidobacterium & $97 \%$ \\
\hline MIADJ3G06 & Acidobacteria & $98 \%$ & Acidobacteria & $98 \%$ & Acidobacteriales & $98 \%$ & Acidobacteriaceae & $98 \%$ & Acidobacterium & $97 \%$ \\
\hline
\end{tabular}


ANEXO B - Resultados das comparações das seqüências parciais da região 16S rRNA obtidas em amostras de solo Terra Preta Antropogênica e respectivos solos adjacentes da região Amazônica Central e Oriental, com as amostras depositadas no banco de dados de seqüências de 16S rRNA do RDP II pelo programa Classifier

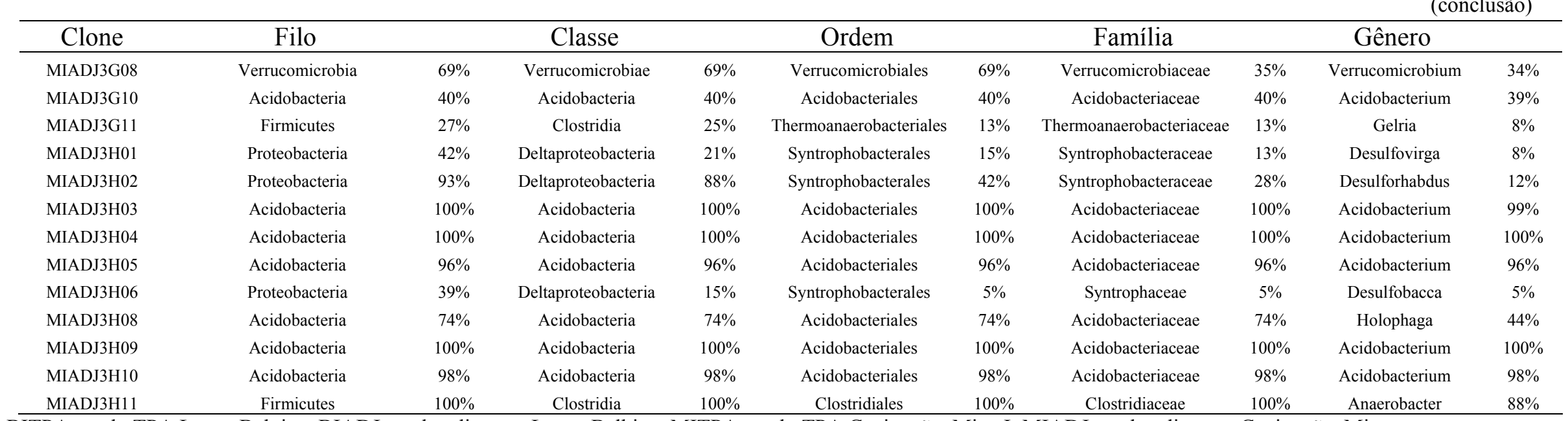

BITPA - solo TPA Lagoa Balnina; BIADJ - solo adjacente Lagoa Balbina; MITPA - solo TPA Caxiuanã - Mina I; MIADJ - solo adjacente Caxiuanã - Mina 